Uniwersytet Przyrodniczy w Lublinie

\title{
Problemy i wyzwania współczesnego rolnictwa oraz ochrony środowiska
}

Tom 1

Środowisko - Roślina - Zwierzę - Produkt 
Problemy i wyzwania współczesnego rolnictwa oraz ochrony środowiska

Tom 1 
Środowisko - Roślina - Zwierzę - Produkt 
Problemy i wyzwania współczesnego rolnictwa oraz ochrony środowiska

Tom 1

pod redakcją Marka Babicza

Lublin 2020 


\title{
Recenzenci
}

dr hab. inż. Gabriel Borowski, prof. uczelni dr hab. Agnieszka Hanaka

\author{
Opracowanie redakcyjne \\ Ewelina Łukasiak \\ Korekta \\ Renata Zelik \\ Projekt okładki \\ Jacek Pałyszka
}

\section{(C) $(1) \Theta \Theta$}

Ten utwór jest dostępny na licencji Creative Commons Uznanie autorstwa Użycie niekomercyjne - Bez utworów zależnych 4.0 Międzynarodowe.

\section{ISBN 978-83-7259-327-6 on-line}

DOI: $10.24326 /$ mon. 2020.6

\author{
VIVIRT \\ Wydawnictwo Uniwersytetu Przyrodniczego w Lublinie \\ ul. Akademicka 15, 20-950 Lublin \\ www.wydawnictwo.up.lublin.pl \\ 8 ark. wyd.
}




\section{Spis treści}

\section{Tomasz Bialek}

Działanie zróżnicowanych dawek herbicydu Axial 50 EC stosowanych z preparatem RSM 28 lub Atpolan 80 EC na miotłę zbożową (Apera spica-venti (L.) P. Beauv.) i owies głuchy (Avena fatua L.)

Effects of varied doses of Axial 50 EC herbicide used with RSM 28 or Atpolan 80 EC on loose silky-bent (Apera spica-venti (L.) P. Beauv.) and common wild oat (Avena fatua L.)

\section{Wojciech Biszczak}

Wpływ współrzędnej uprawy soi (Glycine max L. Merr.) z roślinami ochronnymi na plon, jakość nasion i zachwaszczenie łanu

Influence of intercropping of soybean (Glycine max L. Merr.) with protective plants on yield, quality of seeds and weed infestation

\section{Aleksander Chudy}

Akumulatory litowo-jonowe w samochodach elektrycznych - regeneracja, zastosowanie wtórne i recykling

Lithium-ion batteries in electric vehicles - regeneration, re-using and recycling

\section{Magdalena Cieplak, Sylwia Okoń}

Efektywność genów owsa warunkujących jego odporność na mączniaka prawdziwego i rdzę koronową na terenie Polski

Efficiency of genes conditioning resistance to powdery mildew and crown rust in oats in Poland

Joanna Gmitrowicz-Iwan, Natalia Korcz, Magdalena Myszura, Joanna Trzcińska,

Anna Orlowska

Nowoczesne techniki w geodezji leśnej

Modern techniques in forest geodesy

Mikołaj Kostryco, Mirosława Chwil

Liposomy jako nośniki fitozwiązków

Liposomes as carriers of phytochemicals

Paulina Leśniak, Malgorzata Manastyrska, Jose Luis Valverde Piedra,

Marlena Księżarczyk

Glifosat - zagrożenie dla zdrowia ludzi i zwierząt

Glyphosate - threat to human and animal health

Michał Możejko, Joanna Wawer, Justyna Bohacz

Dynamika zmian liczebności mikroorganizmów i aktywności enzymatycznej gleb wzbogaconych produktami ubocznymi z przemysłu owocowo-warzywnego

Dynamics of changes in microbial count and enzymatic activity of soils supplemented with by-products from the fruit and vegetable processing industry

Klaudia Panasiuk, Marlena Księżarczyk, Mikołaj Szczepan,

Paulina Leśniak, Jose Luis Valverde Piedra

Zalety wykorzystania chromatografii gazowej sprzężonej z tandemową spektrometrią mas do identyfikacji pestycydów chloroorganicznych

Advantages of using gas chromatography tandem mass spectrometry for identification of organochlorine pesticides 
Pawel Szabat, Bartlomiej Sulima, Maria Zielińska, Jan Podolski, Szymon Chmielewski Smartfon vs LiDAR - pomiar wybranych cech struktury drzewostanu miejskiego metodą citizen science

Smartfon vs LiDAR - measurement of selected features of urban tree stand structure by means of citizen science method

Paulina Terlecka, Karol Terlecki

Prozdrowotne właściwości alantoiny

Pro-health properties of allantoin

Eliza Wargala, Agnieszka Weremczuk, Mirosława Chwil

Arbutyna - składnik ziół

Arbutine - herbs component

Julia Wójcik, Adam Gawryluk, Ilona Woźniak-Kostecka

Zachowania komunikacyjne mieszkańców Lublina w kontekście ochrony środowiska

Communication behavior of the Lublin residents in the context of environment conservation

Monika Zająkała

Przemiany polskiego zielarstwa w ostatnim stuleciu

Evolution in Polish herbalism in the last century 
Tomasz Białek $^{1}$

\title{
Działanie zróżnicowanych dawek herbicydu Axial 50 EC stosowanych z preparatem RSM 28 lub Atpolan 80 EC na miotlę zbożową (Apera spica-venti (L.) P. Beauv.) i owies gluchy (Avena fatua L.)
}

Effects of varied doses of Axial 50 EC herbicide used with RSM 28 or Atpolan 80 EC on loose silky-bent (Apera spica-venti (L.) P. Beauv.) and common wild oat (Avena fatua L.)

\begin{abstract}
Wstęp
Duży postęp w rolnictwie, szczególnie w XX w. spowodował, że na mniejszej powierzchni gruntów rolnych jesteśmy w stanie wyprodukować więcej żywności. Obecnie spowodowane jest to głównie postępem genetycznym w hodowli nowych odmian. W perspektywie historycznej to wprowadzenie w rolnictwie herbicydów, czyli substancji eliminujących rośliny niepożądane z łanu, jako pierwsze spowodowało wzrost plonów i podniesienie ich jakości handlowej. Problem zachwaszczenia został pozornie opanowany, patrząc na rynek dostępnych rozwiązań herbicydowych. Nie mniej jednak nie należy zapominać o nim jako podstawowym czynniku wpływającym na plon i jego jakość. Obecnie trwa maksymalizacja produktywności i przypuszczalnie będzie nadal trwała, ponieważ zapotrzebowanie na żywność rośnie, a powierzchnia uprawy roślin maleje [Odum 1977, Falińska 2004]. Wprowadzanie uproszczeń w uprawie roli i zmianowaniu wraz z wyraźniej widocznymi zmianami klimatu przyczyniły się do pogorszenia skuteczności wielu stosowanych na polach środków chwastobójczych. Do takiej sytuacji doprowadziło wiele czynników, ale przede wszystkim jeden - chęć obniżenia kosztów produkcji przez rolników, m.in. poprzez zmniejszanie dawek herbicydów, łączne stosowanie dwóch herbicydów lub dodatków dające efekt synergii, technikę wykonywania zabiegów [Piwowar 2018]. Celem pracy była biologiczna i ekonomiczna ocena zastosowania preparatu Axial 50 EC z nawozem RSM 28 lub adiuwantem Atpolan 80 EC w zwalczaniu miotły zbożowej (Apera spica-venti (L.) P. Beauv.) i owsa głuchego (Avena fatua L.).
\end{abstract}

\footnotetext{
${ }^{1}$ Uniwersytet Przyrodniczy w Lublinie, Wydział Agrobioinżynierii, Studenckie Koło Naukowe Agronomów, tomasz_bialek@o2.p1
} 


\section{Metodyka badań}

Doświadczenie przeprowadzono w 2020 r. w Gospodarstwie Doświadczalnym w Czesławicach, należącym do UP w Lublinie (51 $\left.18^{\circ} 23^{\prime \prime N}, 22^{\circ} 16^{\prime} 2^{\prime \prime E}\right)$. Plastikowe doniczki o pojemności $320 \mathrm{ml}$ napełniono taką samą ilością dokładnie wymieszanego podłoża, składającego się $\mathrm{z}$ torfu odkwaszonego o $\mathrm{pH}=6,5$ i piasku prażonego w proporcji $2: 1$. Następnie wysiano ziarniaki miotły zbożowej (Apera spica-venti (L.) P. Beauv.) i owsa głuchego (Avena fatua L.) w ilości 8 szt. na doniczkę. Badania przeprowadzono w trzech powtórzeniach. Po upływie 14 dni od momentu wysiewu wykonano przerywkę, pozostawiając w każdej doniczce po 3 rośliny. W fazie rozwojowej roślin 2-3 liści $(\mathrm{BBCH}=12-13)$ przeprowadzono zabieg herbicydowy w następujących wariantach:

1. obiekt kontrolny,

2. Axial $50 \mathrm{EC}$ w dawce $0.91 \mathrm{ha}^{-1}$ (s.cz. pinoksaden $-45 \mathrm{~g} \mathrm{ha}^{-1}$ ),

3. Axial $50 \mathrm{EC} 0,721 \mathrm{ha}^{-1}$ (s.cz. pinoksaden $-36 \mathrm{~g} \mathrm{ha}^{-1}$ ) $+5 \%$ RSM 28 ,

4. Axial 50 EC $0,721 \mathrm{ha}^{-1}$ (s.cz. pinoksaden $-36 \mathrm{~g} \mathrm{ha}^{-1}$ ) $+15 \%$ RSM 28 ,

5. Axial 50 EC $0,541 \mathrm{ha}^{-1}$ (s.cz. pinoksaden $-27 \mathrm{~g} \mathrm{ha}^{-1}$ ) $+15 \%$ RSM 28 ,

6. Axial 50 EC $0,541 \mathrm{ha}^{-1}$ (s.cz. pinoksaden $-27 \mathrm{~g} \mathrm{ha}^{-1}$ ) $+25 \%$ RSM 28 ,

7. Axial $50 \mathrm{EC} 0,91 \mathrm{ha}^{-1}$ (s.cz. pinoksaden $-45 \mathrm{~g} \mathrm{ha}^{-1}$ ) + Atpolan $80 \mathrm{EC} 1,51 \mathrm{ha}^{-1}$,

8. Axial $50 \mathrm{EC} 0,721 \mathrm{ha}^{-1}$ (s.cz. pinoksaden $-36 \mathrm{~g} \mathrm{ha}^{-1}$ ) + Atpolan $80 \mathrm{EC} 1,51 \mathrm{ha}^{-1}$.

Obiekt kontrolny stanowił wariant, w którym nie stosowano herbicydu, RSM 28, ani też adiuwantu. Preparaty aplikowano w stacjonarnej komorze opryskowej „Aporo” wyposażonej w ruchomą dyszę typu TeeJet XR 11003-VS, umożliwiającą uzyskanie wydajności cieczy użytkowej równej $2501 \mathrm{ha}^{-1}$ przy ciśnieniu roboczym $0,25 \mathrm{MPa}$.

Po 14 i 21 dniach od wykonania zabiegu herbicydowego dokonano oceny porażenia roślin metodą szacunkową określającą procent uszkodzenia roślin w porównaniu z obiektem kontrolnym (bez herbicydu), w której to ocenie $0 \%$ oznacza brak uszkodzeń chwastu, 100\% - pełne zniszczenie chwastu. Po upływie 21 dni od zabiegu zważono części nadziemne roślin w celu określenia ubytku suchej masy, który świadczy o skuteczności chwastobójczej preparatu.

Do wyliczenia kosztów zabiegu były brane średnie ceny netto środków ochrony roślin i nawozów dostępnych w woj. lubelskim w IV kwartale 2019 r. Analiza cen miała na celu porównanie poszczególnych wariantów, bez uwzględniania kosztów wykonania samego zabiegu, robocizny czy amortyzacji maszyn.

\section{Charakterystyka badanych gatunków}

Miotła zbożowa (Apera spica-venti (L.) P. Beauv.) należy do rodziny wiechlinowatych. Osiąga wysokość 50-100 cm. Korzenie wiązkowe, stosunkowo krótkie, ale gęste. Liście równowąskie, stosunkowo wąskie, o szerokości do 2-6 mm. Pochwy liściowe okrągłe, nagie, z małym, zaostrzonym i postrzępionym języcz- 
kiem. Kwiaty zebrane w wiechowaty kwiatostan. Owocem jest oplewiony ziarniak najczęściej z ością. Apera spica-venti odznacza się dużą konkurencyjnością w stosunku do zbóż i rzepaku. Próg szkodliwości w pszenicy ozimej dla tego chwastu przy 5-procentowym spadku plonu to $10-20$ szt. $\mathrm{m}^{-2}$ (25-40 wiech $\mathrm{m}^{-2}$ ). Ziarniaki kiełkują nawet $\mathrm{w}$ niskich temperaturach jesienią lub wiosną. Miotła zbożowa preferuje miejsca wilgotne, gleby piaszczyste i próchnicze. Nasiona dojrzewają przed żniwami i w czasie omłotu osypują się, uzupełniając ich bank w glebie i na jej powierzchni. Przeciętna żywotność nasion w glebie wg różnych źródeł wynosi ok. 1-5 lat. W ostatnich latach obserwuje się coraz więcej populacji miotły zbożowej odpornych na herbicydy, a zwłaszcza substancje sulfonylomocznikowe (ALS) i inhibitory ACC [Czubiński i Paradowski 2018].

Owies głuchy (Avena fatua L.) należy również do rodziny wiechlinowatych. Jest rośliną jednoroczną, jarą, która może kiełkować w oziminach na wiosnę. Osiąga wysokość 60-120 cm. Korzenie wiązkowe, stosunkowo krótkie, ale gęste. Żdźbło okrągłe w przekroju, dość grube. Liście równowąskie, dość szerokie. Pochwy liściowe w dolnej części owłosione, duży języczek. Kwiaty zebrane w 2-3 kwiatowe kłoski, a te w duże wiechy, najczęściej rozpierzchłe. Owocem jest oplewiony ziarniak, długości kilkunastu $\mathrm{mm}$, zaopatrzony w długą do $30 \mathrm{~mm}$ ość. Przeciętna żywotność nasion w glebie wg różnych źródeł wynosi ok. 10 lat. Próg szkodliwości dla tego gatunku chwastu to: 10 roślin $\mathrm{m}^{-2}-$ powodujący 10-procentowy spadek plonu, z kolei $50 \mathrm{szt} . / \mathrm{m}^{2}$ powoduje 30procentowy spadek plonu, a $100 \mathrm{szt} . \mathrm{m}^{-2}$ - całkowitą utratę plonu. Avena fatua preferuje miejsca wilgotne, gleby próchnicze i gliniaste, bogate w azot i wapń. Jest to gatunek blisko spokrewniony $\mathrm{z}$ owsem siewnym, co praktycznie uniemożliwia jego zwalczenie $\mathrm{w}$ uprawie tego gatunku i w uprawach mieszanek $\mathrm{z}$ jego udziałem. Podobnie jak w przypadku miotły zbożowej, zidentyfikowano populacje owsa głuchego odporne na inhibitory ACC i ALS [Czubiński i Paradowski 2018].

\section{Charakterystyka herbicydu Axial 50 EC}

Efektywność zwalczania chwastów zależy nie tylko od odpowiedniego doboru herbicydów, ale także od warunków pogodowych w momencie oprysku i kilka dni po zabiegu oraz od składu gatunkowego zbiorowiska chwastów i faz rozwojowych, w jakich się w danej chwili znajdują [Nalewaja i Matysiak 1993].

Herbicyd Axial 50 EC jest to środek z substancją czynną pinoksadenem (związek z grupy fenylopirazolin), którego stężenie $\mathrm{w}$ herbicydzie wynosi $50 \mathrm{~g} \mathrm{l}^{-1}$ $(5,17 \%)$. Axial $50 \mathrm{EC}$ to herbicyd selektywny o działaniu układowym, stosowany nalistnie, w formie koncentratu do sporządzania emulsji wodnej. Zgodnie z klasyfikacją HRAC substancja czynna zaliczana jest do grupy A (inhibitory ACCazy).

„Axial $50 \mathrm{EC}$ jest herbicydem pobieranym przez liście chwastów, szybko przemieszczającym się do stożków wzrostu pędów i korzeni. W roślinie powoduje zahamowania biosyntezy kwasów tłuszczowych w początkowej fazie ich syntezy. 
Objawy działania środka są widoczne stosunkowo późno, po kilku lub kilkunastu dniach od zabiegu. Do pierwszych objawów jego działania zalicza się zahamowanie wzrostu chwastu, następnie występują zmiany zabarwienia liści, często na antocyjanowe lub chloroza. Szczególnie są one wyraźne widoczne na młodych liściach znajdujących się w pochwach liściowych lub w pobliżu kolanka. Zasychanie i zamieranie roślin następuje od wierzchołka wzrostu" [Axial 50 EC... 2017]. Do chwastów wrażliwych należą te gatunki, które zostały objęte niniejszym badaniem, czyli miotła zbożowa, owies głuchy, ale także chwastnica jednostronna oraz wyczyniec polny.

Zgodnie z etykietą środek należy stosować w okresie najwyższej wrażliwości chwastów wiechlinowatych, tj. od pojawienia się pierwszego liścia do rozpoczęcia fazy krzewienia. W zwalczaniu owsa głuchego i miotły zbożowej maksymalna dawka środka dla jednorazowego zastosowania wynosi $0,91 \mathrm{ha}^{-1}$, natomiast dawka zalecana dla tych gatunków to $0,6-0,91 \mathrm{ha}^{-1}$.

Zgodnie z etykietą środka ochrony roślin Axial 50 EC zaleca się 200-300 1 wody ha ${ }^{-1}$ i opryskiwanie średniokropliste.

\section{Charakterystyka nawozu RSM}

RSM to wysokoskoncentrowany nawóz azotowy w formie wodnego roztworu saletrzano-mocznikowego. Zawiera nieszkodliwy dla środowiska inhibitor korozji. Roztwór produkowany jest w trzech stężeniach $(28 \% \mathrm{~N}, 30 \% \mathrm{~N}, 32 \% \mathrm{~N})$. W badaniu zastosowano RSM o zawartości $28 \% \mathrm{~N}$. Azot w tym nawozie występuje w trzech formach: $50 \% \mathrm{~N} \mathrm{w}$ formie amidowej, $25 \% \mathrm{~N} \mathrm{w}$ formie amonowej i $25 \% \mathrm{~N}$ w formie azotanowej. RSM stosowany jest do nawożenia przedsiewnego i pogłównego roślin [Fotyma i Mercik 1995, Filipek 2006]. Ponadto RSM może być używany jako środek wspomagający działanie herbicydów. Pozytywny wpływ dodatku RSM do cieczy użytkowej wynika najprawdopodobniej z obecności w roztworze saletrzano-mocznikowym jonów amonowych, które wpływają na przebieg wchłaniania substancji aktywnej herbicydów przez błonę komórkową [Gronwald i in. 1993]. Zdaniem Nalewaja i Matysiaka [1993] oraz Joosta [1998] korzystne działanie RSM polega też na ograniczeniu antagonistycznego wpływu kationów zawartych w wodach naturalnych, optymalizacji osadów powstałych po odparowaniu wody z cieczy opryskowej oraz zwiększeniu rozpuszczalności herbicydów. Mieszaniny środków ochrony roślin z RSM mają niski tzw. punkt skraplania, który wpływa na wydłużenie czasu wysychania kropli. Kropla czystej wody zaczyna parować w powietrzu o wilgotności już poniżej $100 \%$, tymczasem czysty RSM paruje dopiero od wilgotności 30\%. Oznacza to, że dodatek RSM sprawia, że kropla rozlewa się na liściu i zwiększa powierzchnię pokrycia, pozostaje dłużej wilgotna, a s.cz. może być przez dłuższy czas pobierana przez roślinę. Wadą jednak jest to, że azot szybciej wnika i istnieje ryzyko poparzeń. 


\section{Charakterystyka adiuwanta Atpolan 80 EC}

Adiuwanty dodaje się do większości herbicydów stosowanych nalistnie w celu zwiększenia ich skuteczności chwastobójczej [McWhorter 1982]. Atpolan 80 EC jest adiuwantem, czyli środkiem wspomagającym w formie płynu, przeznaczonym do łącznego stosowania z cieczą użytkową niektórych środków chwastobójczych i grzybobójczych rozpylanych za pomocą aparatury naziemnej. Substancją biologicznie czynną jest olej parafinowy SN $-76 \%$. Głównymi skutkami działania środka są obniżenie napięcia powierzchniowego cieczy użytkowej środków ochrony roślin, poprawa równomierności pokrycia cieczą użytkową opryskiwanych powierzchni, a także zwiększenie skuteczności działania środków chwastobójczych, co pozwala na zmniejszenie dotychczas zalecanych dawek. Dawka zalecana przez producenta to $1,51 \mathrm{ha}^{-1}$.

Zalety, które stanowią o przewadze RSM nad adiuwantem Atpolan, to zawartość azotu w RSM (czyli może służyć jako uzupełnienie odżywiania rośliny uprawnej), a także korzyść logistyczna (w wielu gospodarstwach RSM to nawóz do stosowania przedsiewnego czy pogłównego i znajduje się on na miejscu).

\section{Omówienie wyników badań}

W pierwszym terminie oceny skuteczności działania herbicydu, czyli 14 dni po wykonaniu zabiegu herbicydowego, największe porażenie roślin owsa głuchego odnotowano w wariancie 6 (Axial 50 EC dawka 0,54 1/ha + roztwór z 25\% RSM 28)

Tabela 1. Uszkodzenie roślin Avena fatua (\%) oraz ubytek masy części nadziemnych roślin (\%)

\begin{tabular}{|c|c|c|c|}
\hline \multirow[b]{2}{*}{ Wariant herbicydowy } & \multicolumn{2}{|c|}{ Uszkodzenie roślin (\%) } & \multirow{2}{*}{$\begin{array}{c}\text { Ubytek masy } \\
\text { (\% względem } \\
\text { obiektu } \\
\text { kontrolnego) }\end{array}$} \\
\hline & $\begin{array}{c}14 \text { dni } \\
\text { po zabiegu } \\
\text { herbicydowym }\end{array}$ & $\begin{array}{c}21 \mathrm{dni} \\
\text { po zabiegu } \\
\text { herbicydowym }\end{array}$ & \\
\hline 1 - Kontrola & 0 & 0 & 0 \\
\hline 2 - Axial $50 \mathrm{EC}-0,91 / \mathrm{ha}$ & 5 & 100 & 95 \\
\hline $\begin{array}{l}3 \text { - Axial } 50 \text { EC - } \\
\quad 0,72 \text { 1/ha + roztwór z 5\% RSM } 28\end{array}$ & 5 & 95 & 93 \\
\hline $\begin{array}{l}4 \text { - Axial } 50 \text { EC - } \\
\quad 0,72 \text { 1/ha + roztwór z } 15 \% \text { RSM } 28\end{array}$ & 10 & 100 & 96 \\
\hline $\begin{array}{l}5 \text { - Axial } 50 \text { EC - } \\
\quad 0,54 \text { 1/ha + roztwór z 15\% RSM } 28\end{array}$ & 20 & 95 & 89 \\
\hline $\begin{array}{l}6 \text { - Axial } 50 \text { EC - } \\
0,54 \text { 1/ha + roztwór z 25\% RSM } 28\end{array}$ & 30 & 100 & 97 \\
\hline $\begin{array}{l}\text { 7- Axial } 50 \text { EC - } \\
0,9 \text { 1/ha }+ \text { Atpolan } 80 \mathrm{EC}\end{array}$ & 30 & 95 & 90 \\
\hline $\begin{array}{l}8-\text { Axial } 50 \mathrm{EC}- \\
\quad 0,72 \mathrm{l} / \mathrm{ha}+\text { Atpolan } 80 \mathrm{EC}\end{array}$ & 20 & 95 & 87 \\
\hline
\end{tabular}


Tabela 2. Uszkodzenie roślin Apera spica-venti (\%)

\begin{tabular}{|c|c|c|c|}
\hline \multirow[b]{2}{*}{ Wariant herbicydowy } & \multicolumn{2}{|c|}{ Uszkodzenie roślin (\%) } & \multirow{2}{*}{$\begin{array}{c}\text { Ubytek masy } \\
(\% \text { względem } \\
\text { obiektu } \\
\text { kontrolnego })\end{array}$} \\
\hline & $\begin{array}{c}14 \mathrm{dni} \\
\text { po zabiegu } \\
\text { herbicydowym }\end{array}$ & $\begin{array}{c}21 \mathrm{dni} \\
\text { po zabiegu } \\
\text { herbicydowym }\end{array}$ & \\
\hline $1-$ Kontrola & 0 & 0 & 0 \\
\hline $2-$ Axial $50 \mathrm{EC}-0,91 / \mathrm{ha}$ & 0 & 5 & 10 \\
\hline $\begin{array}{l}3 \text { - Axial } 50 \text { EC - } \\
\quad 0,721 / \text { ha }+ \text { roztwór z } 5 \% \text { RSM } 28\end{array}$ & 0 & 5 & 12 \\
\hline $\begin{array}{l}4 \text { - Axial } 50 \text { EC - } \\
\quad 0,72 \text { 1/ha + roztwór z 15\% RSM } 28\end{array}$ & 10 & 15 & 22 \\
\hline $\begin{array}{l}5 \text { - Axial } 50 \text { EC - } \\
\quad 0,54 \text { 1/ha + roztwór z 15\% RSM } 28\end{array}$ & 0 & 5 & 7 \\
\hline $\begin{array}{l}6 \text { - Axial } 50 \text { EC - } \\
\quad 0,54 \text { 1/ha + roztwór z 25\% RSM } 28\end{array}$ & 5 & 10 & 19 \\
\hline $\begin{array}{l}7 \text { - Axial } 50 \mathrm{EC}- \\
0,9 \text { 1/ha }+ \text { Atpolan } 80 \mathrm{EC}\end{array}$ & 0 & 5 & 8 \\
\hline $\begin{array}{l}8-\text { Axial } 50 \mathrm{EC}- \\
0,72 \mathrm{1} / \mathrm{ha}+\text { Atpolan } 80 \mathrm{EC}\end{array}$ & 0 & 5 & 3 \\
\hline
\end{tabular}

i 7 (Axial 50 EC dawka 0,9 1/ha + Atpolan 80 EC). Ocena wizualna w tym terminie nie wykazała porażenia roślin miotły zbożowej przez stosowane warianty herbicydowe (tab. 1, 2).

W 21 dniu po zabiegu herbicydowym zanotowano duże porażenie roślin owsa głuchego, występujące na poziomie $95-100 \%$. Redukcja masy części nadziemnych roślin tego gatunku wynosiła od 87 do $97 \%$. Świadczy to o dużej skuteczności działania wszystkich testowanych wariantów herbicydowych względem tego gatunku. W przypadku miotły zbożowej uszkodzenia roślin były bardzo małe, na poziomie $5-15 \%$. Również redukcja biomasy roślin była niewielka i wynosiła od 3 do $22 \%$. Wskazuje to na brak reakcji tej rośliny na badane warianty herbicydowe i wynikać może z występowania odporności badanego biotopu miotły zbożowej na pinoksaden (tab. 1,2).

Przeprowadzony eksperyment wykazał, że dodawanie do cieczy opryskowej wspomagacza zapewnia skuteczne zwalczanie chwastów wrażliwych, nawet w przypadku dużego obniżenia dawki preparatu, co znajduje potwierdzenie w wielu opracowaniach naukowych [Woźnica 2003, Idziak i Woźnica 2008, Kwiatkowski i in. 2011, Kierzek i in. 2014]. Zastosowanie herbicydu Axial 50 EC z nawozem RSM 28 skutkuje szybszą reakcją rośliny na zabieg samym herbicydem. Efekt ten można wythumaczyć tym, że azot w postaci amidowej zawarty w RSM rozpuszcza kutikulę, powodując łatwiejsze wnikanie s.cz. do rośliny [Kopcewicz i Lewak 2012].

Z przeprowadzonej analizy wynika, że najtańszym rozwiązaniem okazał się wariant 5, a w następnej kolejności wariant 3 i 6 . Koszty przeprowadzenia za- 
biegu z wariantów 2, 4, 8 kształtowały się na podobnym poziomie. Najdroższy okazał się wariant 7, w którym zastosowano herbicyd w pełnej dawce i adiuwant Atpolan 80 EC (tab. 3).

Tabela 3. Koszty wykonania zabiegów herbicydowych

\begin{tabular}{|c|c|}
\hline Wariant herbicydowy & Koszt (PLN netto) \\
\hline 1 - Kontrola & 0 \\
\hline $2-$ Axial $50 \mathrm{EC}-0,91 \mathrm{ha}^{-1}$ & 141 \\
\hline $3-$ Axial $50 \mathrm{EC}-0,721$ ha $^{-1}+$ roztwór z 5\% RSM 28 & 121 \\
\hline 4 - Axial 50 EC $-0,721$ ha $^{-1}+$ roztwór z $15 \%$ RSM 28 & 139 \\
\hline 5 - Axial $50 \mathrm{EC}-0,541 \mathrm{ha}^{-1}+$ roztwór z $15 \%$ RSM 28 & 111 \\
\hline 6 - Axial $50 \mathrm{EC}-0,541 \mathrm{ha}^{-1}+$ roztwór z 25\% RSM 28 & 129 \\
\hline 7 - Axial $50 \mathrm{EC}-0,91 \mathrm{ha}^{-1}+$ Atpolan $80 \mathrm{EC}$ & 164 \\
\hline $8-$ Axial $50 \mathrm{EC}-0,721 \mathrm{ha}^{-1}+$ Atpolan $80 \mathrm{EC}$ & 136 \\
\hline
\end{tabular}

Zabieg herbicydowy traktujemy jako koszt produkcji. W modelu ekonomicznym, kiedy rosną lub spadają koszty danej działalności, a wszystkie inne czynniki, łącznie z ceną danego produktu, pozostają niezmienione, zmniejsza się lub odpowiednio zwiększa się zysk (dochód) [Heijman i Krzyżanowska 1997]. RSM lub Atpolan 80 EC w stosunku do herbicydu Axial są jedynie produktami komplementarnymi i mają za zadanie go uzupełnić, a nie zastąpić. Koszt jednostkowy zabiegu zależy w głównej mierze od kosztów zakupu. Koszty ocenianych w doświadczeniu zabiegów herbicydowych nie różnią się znacząco (tab. 3). W przedstawionej analizie nie brano pod uwagę wartości dodanej, jaką jest azot pochodzący z RSM, wpływający dodatnio na plon i jakość ziarna. Ponadto nie uwzględniono również fitotoksycznego działania środków na roślinę uprawną. Biorąc pod uwagę, że zabieg wykonuje się we wczesnych fazach rozwojowych rośliny uprawnej i w dawce, która nie działa fitotoksycznie, można zakładać, że nie będzie on miał niekorzystnego wpływu na rozwój roślin uprawianego gatunku. Ponadto RSM wpływa dodatnio na ciecz roboczą, w pewien sposób ją stabilizując, w związku z czym oprysk daje nam szersze możliwości na wykonanie zabiegu zarówno jesienią przy niskich temperaturach, jak i wiosną podczas suszy [Woźnica 2012, Kierzek 2017].

\section{Odporność chwastów na herbicydy}

Zdaniem Adamczewskiego [2014] w ostatnich latach rolnicy zauważają obniżoną skuteczność działania środków chwastobójczych. Coraz częściej mamy do czynienia z występowaniem odporności chwastów na herbicydy. Odporność chwastów to dziedziczna zdolność niektórych biotypów w danej populacji do 
przeżycia zabiegu herbicydowego, który w normalnych warunkach stosowania powodowałby zniszczenie tej populacji chwastów.

W każdej populacji chwastów pojawiają się pojedyncze osobniki, które są w stanie przetrwać zabieg i wydać nasiona. Czasem jest to samorzutna mutacja genu, która uodparnia osobnika na dany mechanizm działania herbicydu (tzw. odporność w miejscu działania), a czasem chwast „przyzwyczaja się” do herbicydu i znajduje sposób, żeby zmetabolizować szkodliwe dla siebie substancje czynne w nim zawarte (tzw. odporność metaboliczna). Ten drugi rodzaj powstawania odporności zazwyczaj zachodzi stopniowo, odporność związana z mutacją genu pojawia się nagle i szybko się rozprzestrzenia.

Jeśli w kolejnych sezonach wegetacyjnych i uprawach stosujemy substancję biologicznie czynną o tym samym mechanizmie działania, osobniki wrażliwe są zwalczane, a selekcjonowane rośliny uodpornione na działanie herbicydu. Po kilku sezonach na polu mogą występować tylko osobniki, które nie reagują na dany herbicyd.

Występuje kilka rodzajów odporności. Odporność prosta (pojedyncza), czyli odporność na herbicydy z tej samej grupy chemicznej o tym samym mechanizmie działania. W praktyce występuje bardzo krótkotrwale i rzadko. Najczęściej pojawia się, gdy przez wiele lat na danym polu i w jego okolicy używany jest tylko jeden preparat i mamy do czynienia $\mathrm{z}$ wadliwym płodozmianem.

Odporność krzyżowa to odporność na różne substancje aktywne herbicydów w obrębie tego samego mechanizmu działania. Jest następnym krokiem po odporności prostej. W praktyce występuje w przypadku zamiany nieskutecznej substancji biologicznie czynnej na inną, ale o tym samym mechanizmie działania. Zjawisko najbardziej rozpowszechnione na polach naszego kraju [Woźnica 2012]. Odporność wielokrotna to odporność na 2 lub więcej mechanizmów działania herbicydów. Jest to najgorszy typ odporności, ponieważ pojedyncze produkty z różnych grup chemicznych o odmiennych mechanizmach działania przestają być skuteczne, a nawet ich mieszaniny w pełnych dawkach nie gwarantują $100 \%$ zwalczania chwastów. W takim przypadku należy wprowadzać preparaty o innym mechanizmie działania (na który nie ma odporności) oraz wprowadzać zabiegi sekwencyjne. W skrajnych przypadkach trzeba zmienić płodozmian, wprowadzając inne gatunki w miejsce tych, które muszą zostać ograniczone, bądź całkowicie wyłączone [Weber i Gołębiowska 2009, Woźnica 2012, Adamczewski 2014, Forouzesh i in. 2015].

\section{Wnioski}

1. W przeprowadzonym eksperymencie stwierdzono wysoką efektywność działania wszystkich wariantów herbicydowych względem owsa głuchego. W odniesieniu do miotły zbożowej herbicyd Axial 50 EC nie wykazywał działania chwastobójczego, co wskazuje na wykształconą odporność u biotypu na substancję biologicznie czynną - pinoksaden. 
2. W badaniach stwierdzono występowanie efektu synergii po zastosowaniu herbicydu Axial 50 EC z adiuwantem Atpolan 80 EC lub nawozem RSM 28, przejawiającego się szybszą reakcją chwastów i większym stopniem porażenia.

3. Koszty zabiegów herbicydowych ocenianych $w$ doświadczeniu nie różniły się znacząco. Najtańszy okazał się wariant z zastosowaniem herbicydu Axial $50 \mathrm{EC}$ w dawce 0,54 1/ha z roztworem 15\% RSM 28.

\section{Bibliografia}

Adamczewski K., 2014. Odporność chwastów na herbicydy. PWN, Warszawa.

Axial 50 EC. Załącznik do decyzji MRiRW nr R- 488/2017d z dnia 03.10.2017 r. zmieniającej zezwolenie MRiRW nr R - 105/2014 z dnia 09.07.2014 r. https://www.gov.pl/documents/ 912055/913531/Axial 50 EC.pdf/7d7797a3-2297-e87f-4896-b899ee831f07?version=1.0

Czubiński T., Paradowski A., 2018. Atlas chwastów. PWR, Poznań.

Falińska K., 2004. Ekologia roślin. Wyd. Nauk. PWN, Warszawa.

Filipek T., 2006. Chemia rolna. Wyd. AR Lublin.

Forouzesh A., Zand E., Soufizadeh S., Samadi Foroushani S., 2015. Classification of herbicides according to chemical family for weed resistance management strategies - an update. Weed Res. 55(4), 334-358. https://doi.org/10.1111/wre.12153

Fotyma M., Mercik S., 1995. Chemia rolna. PWN, Warszawa.

Gronwald J.W., Jourdan D.L., Wyse D.L., Somers D.A., Magnusson M., 1993. Effect of Ammonium Sulfate on Absorption of Imazethapyr by Quackgrass (Elytrigia repens) and Maize (Zea mays) Cell Suspension Cultures. Weed Sci. 41, 325-334.

Heijman W., Krzyżanowska Z., 1997. Ekonomika rolnictwa. SGGW, Warszawa.

Idziak R., Woźnica Z., 2008. Skuteczność chwastobójcza herbicydu Callisto 100 SC stosowanego $\mathrm{z}$ adiuwantami i nawozem mineralnym. Acta Agrophys. 11(2), 403-410.

Joost R.E., 1998. Benefits and mode of action nitrogen fertilizers as adjuvants. Proc. Fifth Int. Symposium on Adjuvants for Agrochemicals 1, 259-266.

Kierzek R., 2017. Adiuwanty i ich wpływ na działanie środków ochrony roślin. Rol. ABC 8(323), http://rolniczeabc.pl/460885,Adiuwanty-i-ich-wplyw-na-dzialanie-srodkow-ochrony-roslin.html

Kierzek R., Wachowiak M., Krawczyk R., Ratajkiewicz H., 2014. Skuteczność herbicydów w uprawie kukurydzy w zależności od doboru adiuwantów i rozpylaczy. Probl. Inż. Rol., 22(2), 29-39.

Kopcewicz J., Lewak S., 2012. Fizjologia roślin. PWN, Warszawa.

Kwiatkowski C., Wesołowski M., Juszczak J., 2011. Wpływ adiuwantów oraz zredukowanych dawek środków ochrony roślin na skład pokarmowy ziarna jęczmienia jarego. Acta Agrophys., 17(2), 345-357.

McWhorter C.G., 1982. The use of adjuvants. W: R.H. Hodgson (red.), Adjuvants for herbicides Weed Science Society of America, Champaign, IL, 10-25.

Nalewaja J.D., Matysiak R., 1993. Influence of diammoniumsulfateand other salts onglyphosatephytotoxicity. Pestic. Sci. 38, 77-84.

Odum E.P., 1977. Podstawy ekologii. PWRiL, Warszawa.

Piwowar A., 2018. Chemiczna ochrona roślin we współczesnym rolnictwie w perspektywie ekonomicznej i ekologicznej - korzyści, koszty oraz preferencje. UE, Wrocław.

Weber R., Gołębiowska H., 2009. Wpływ herbicydu Titus 25 WG na zmienność plonowania odmian kukurydzy na Dolnym Śląsku. Fragm. Agron. 26(4), 181-188.

Woźnica Z., 2012. Odporność chwastów na herbicydy. W: Z. Woźnica, Herbologia. Podstawy biologii, ekologii i zwalczania chwastów. PWRiL, Poznań, 347-364.

Woźnica Z., 2003. Współdziałanie adiuwantów a skuteczność chwastobójcza herbicydów. Prog. Plant Protect./Post. Ochr. Rośl. 43, 473-480. 


\title{
Wojciech Biszczak ${ }^{1}$
}

\section{Wpływ współrzędnej uprawy soi (Glycine max L. Merr.) z roślinami ochronnymi na plon, jakość nasion i zachwaszczenie lanu}

\author{
Influence of intercropping of soybean (Glycine max L. Merr.) with protective plants \\ on yield, quality of seeds and weed infestation
}

\begin{abstract}
Wstęp
Większość intensywnych systemów rolniczych dąży do maksymalizacji produktywności upraw zredukowanych do jednego lub kilku gatunków. Takie systemy zaczynają być powszechnie krytykowane ze względu na ich negatywny wpływ na środowisko poprzez degradację gleb, zanieczyszczenia chemiczne oraz utratę bioróżnorodności siedlisk [Giller i in. 1997, Griffon 1999, Tilman 2002]. Systemy rolnicze oparte na jednoczesnym wprowadzeniu wielu gatunków do uprawy mogą być uważane jako praktyczne zastosowanie zasad ekologicznych opartych na różnorodności biologicznej i pozytywnych interakcjach między roślinami [Vandermer 1998].

Uprawa współrzędna to system polegający na jednoczesnym wysiewie bądź wysadzeniu dwóch lub więcej gatunków roślin na tym samym polu i w tym samym sezonie wegetacyjnym [Robak i Wiech 1998]. Zaletą takiej metody uprawy jest zmniejszenie niekorzystnego wpływu agrofagów na plonowanie i zdrowotność łanu oraz ochrona gleby przed erozją. Zmienność gatunkowa sprzyja rozwojowi fauny i flory glebowej, z której wynika jej zdrowotność [Sartorius 1993]. Idea uprawy kilku gatunków roślin jednocześnie na tym samym polu pochodzi z regionów świata takich jak: Indie, kraje Ameryki Łacińskiej oraz południowo-wschodnia Azja [Khan i in. 1997, Wiech 2000].

Jedną $\mathrm{z}$ podstawowych wad $\mathrm{w}$ uprawach współrzędnych jest konkurencja międzygatunkowa o wodę, składniki pokarmowe oraz światło. Efektem konkurencji w uprawie rośliny motylkowatej wraz z rośliną zbożową jest zmniejszenie plonu nasion roślin motylkowatych oraz ziarna rośliny zbożowych [Muoneke i in. 2007]. Zmiany morfologiczne, takie jak zmniejszenie powierzchni wegetacyjnej czy też wytworzenie mniejszej liczby strąków, mogą być skutkiem zacieniania
\end{abstract}

\footnotetext{
1 Uniwersytet Przyrodniczy w Lublinie, Wydział Agrobioinżynierii, Katedra Herbologii i Technik Uprawy Roślin, wojciech.biszczak@up.lublin.pl
} 
przez drugi gatunek. Jest to widoczne przede wszystkim w początkowych fazach wzrostu [Foroutan-pour i in. 1999]. Wynika to $\mathrm{z}$ faktu, że zboża są bardziej konkurencyjne niż rośliny strączkowe w pobieraniu azotu z gleby ze względu na szybszy rozwój korzeni i większe zapotrzebowanie na ten składnik [Corre-Hellou i in. 2006]. Uprawa roślin wraz z gatunkami silnie dominującymi, mimo zmniejszenia ich plonowania, może wywierać pozytywny wpływ na zawartość poszczególnych składników chemicznych nasion [Liu i in. 2016]. Współrzędna uprawa pasowa $\mathrm{w}$ istotny sposób ogranicza zachwaszczenie roślin, co może się przyczynić do zmniejszenia dawek herbicydów stosowanych w uprawach poprzez wykorzystanie naturalnych oddziaływań roślin uprawnych na chwasty [Liebman i Dyck 1993, Głowacka 2007]. Ponadto niektóre kombinacje upraw mieszanych wykazują istotną zdolność ograniczania szkodników i chorób [Trenbath 1993, Hauggaard-Nielsen i in. 2001]. Rośliny motylkowate, a w szczególności soja (ze względu na siew w relatywnie dużej rozstawie rzędów), są uprawami, w których najczęściej stosuje się wysiew z innymi gatunkami roślin uprawnych [Bobrecka-Jamro 1999].

\section{Material i metody}

Doświadczenie polowe założono metodą „split-plot”. Pole doświadczalne położone było na glebie płowej, wytworzonej z lessu. Zawartość makroskładników w warstwie ornej gleby plasowała się na średnim poziomie. Suma opadów w sezonie wegetacyjnym wynosiła $464,6 \mathrm{~mm}$. Ze względu na suszę panującą na początku okresu wegetacyjnego wschody soi były utrudnione.

Schemat doświadczenia zakładał wysiew rośliny ochronnej w międzyrzędzia soi zwyczajnej Glycine max (L.) Merr. Badaniami objęto dwie odmiany soi: 'Annushka' i 'Mavka'. Komponentami w mieszance były rośliny oleiste: len oleisty odmiany 'Bukoz', gorczyca biała odmiany 'Metex' i rzodkiew oleista odmiany 'Romesa'.

Przedplonem dla soi była gryka zwyczajna. Poprzez nawożenie mineralne do gleby wniesione zostało $18 \mathrm{~kg}$ azotu $\cdot \mathrm{ha}^{-1}, 60 \mathrm{~kg}$ fosforu $\cdot \mathrm{ha}^{-1}, 90 \mathrm{~kg}$ pota$\mathrm{su} \cdot \mathrm{ha}^{-1}$ oraz $21 \mathrm{~kg}$ siarki $\cdot \mathrm{ha}^{-1}$. Siew współrzędny soi wykonano rzędowo, przemiennie $\mathrm{z}$ rośliną ochronną w I dekadzie maja. Rozstawa rzędów soi wynosiła $25 \mathrm{~cm}$, natomiast między soją a rośliną ochronną $12,5 \mathrm{~cm}$.

Nasiona przeznaczone do siewu zaszczepiono bakteriami Rhizobium japonicum. Z odmiany 'Mavka' wysiano $110 \mathrm{~kg}$ soi ' $\mathrm{ha}^{-1}$, a z odmiany 'Annushka' $120 \mathrm{~kg} \cdot \mathrm{ha}^{-1}$, co pozwoliło na uzyskanie obsady $91 \mathrm{i} 89 \mathrm{szt} \cdot \mathrm{m}^{-2}$. Norma wysiewu rośliny ochronnej w postaci lnu oleistego wynosiła $6,4 \mathrm{~kg} \cdot \mathrm{ha}^{-1}$ (obsada $115 \mathrm{ro-}$ ślin na $\mathrm{m}^{2}$ ), gorczycę białą wysiano w ilości $3,4 \mathrm{~kg} \cdot \mathrm{ha}^{-1}$ (obsada 35 roślin na $\mathrm{m}^{2}$ ), natomiast rzodkiew oleistą wysiano w ilości $3,8 \mathrm{~kg} \cdot \mathrm{ha}^{-1}$ (obsada 30 roślin na $\mathrm{m}^{2}$ ). Uprawa współrzędna nie zakładała ochrony chemicznej łanu. 
Schemat doświadczenia uwzględniał następujące czynniki:

A. Sposób siewu soi:

1. obiekt kontrolny (siew czysty soi w rozstawie $12,5 \mathrm{~cm}$ ),

2. siew współrzędny soi wraz $z$ lnem oleistym w układzie $1 / 1$ i rozstawą $12,5 \mathrm{~cm}$ (jeden rząd soi przemiennie $\mathrm{z}$ jednym rzędem lnu oleistego),

3. siew współrzędny soi wraz $\mathrm{z}$ gorczycą białą $\mathrm{w}$ układzie $1 / 1$ i rozstawą $12,5 \mathrm{~cm}$ (jeden rząd soi przemiennie z jednym rzędem gorczycy białej),

4. siew współrzędny soi wraz z rzodkwią oleistą $w$ układzie $1 / 1$ i rozstawą $12,5 \mathrm{~cm}$ (jeden rząd soi przemiennie z jednym rzędem rzodkwi oleistej).

B. Odmiany soi:

1. 'Annushka',

2. 'Mavka'.

Określano następujące cechy wynikowe:

1. wysokość roślin oraz wysokość osadzenia pierwszego strąka soi,

2. plon nasion,

3. masę tysiąca nasion,

4. zawartość tłuszczu surowego i białka,

5. zachwaszczenie łanu soi - oceniane metodą ilościowo-wagową przed zbiorem nasion soi.

Rezultaty badań opracowano statystycznie metodą analizy wariancji. Średnie porównano za pomocą testu Tukeya przy poziomie istotności $\mathrm{p}=0,05$.

\section{Wyniki}

Niezależnie od innych czynników plon nasion 'Mavki' był istotnie wyższy od plonu 'Annushki'. Największy plon nasion odnotowano w obiektach, gdzie soję wysiewano współrzędnie z lnem oleistym, istotnie mniejszy w obiekcie kontrolnym i najmniejszy na poletkach z rzodkwią oleistą oraz gorczycą białą (tab. 1).

Tabela 1. Plon soi $\left(\mathrm{kg} \cdot \mathrm{ha}^{-1}\right)$

\begin{tabular}{|l|c|c|c|}
\hline \multirow{2}{*}{ Gatunek rośliny ochronnej } & \multicolumn{2}{|c|}{ Odmiana soi } & \multirow{2}{*}{ Średnia } \\
\cline { 2 - 3 } & 'Mavka' & 'Annushka' & \\
\hline Kontrola w siewie czystym & 610,00 & 484,00 & 547,00 \\
Rzodkiew oleista & 396,67 & 331,00 & 363,84 \\
Gorczyca biała & 507,33 & 363,67 & 435,50 \\
Len oleisty & 773,33 & 475,67 & 624,50 \\
Średnia & 571,83 & 413,59 & - \\
\hline \multirow{2}{*}{ NIR $_{0,05}$} & Odmiana & 72,69 \\
& Roślina ochronna & 60,41 \\
& \multicolumn{2}{|l}{ Odmiana $\times$ roślina ochronna } & 88,62 \\
\hline
\end{tabular}


Wysokość roślin różniła się istotnie w zależności od odmian oraz gatunku współrzędnej rośliny ochronnej. Różnice wysokości roślin soi pomiędzy odmianami wynikały przede wszystkim z cech genetycznych odmian (tab. 2).

Zastosowane czynniki doświadczenia w sposób istotny wpłynęły na wysokość osadzenia pierwszego strąka soi. Cecha ta była zależna głównie od odmiany soi. Najwyższym osadzeniem dolnych strąków odznaczały się rośliny 'Mavki' pochodzące z uprawy współrzędnej soi wraz z rzodkwią oleistą. W obiektach, w których wysiewano odmianę 'Annushka', wysokość osadzenia pierwszego strąka była istotnie mniejsza niż na poletkach z odmianą 'Mavka' (tab. 3).

Tabela 2. Wysokość roślin soi (cm)

\begin{tabular}{|l|c|c|c|}
\hline \multirow{2}{*}{ Gatunek rośliny ochronnej } & \multicolumn{2}{|c|}{ Odmiana soi } & \multirow{2}{*}{ Średnia } \\
\cline { 2 - 3 } & 'Mavka' & 'Annushka' & \\
\hline Kontrola w siewie czystym & 73 & 56,3 & 64,65 \\
Rzodkiew oleista & 55,3 & 50,3 & 52,8 \\
Gorczyca biała & 67,3 & 52,3 & 59,8 \\
Len oleisty & 76,3 & 60,7 & 68,5 \\
Średnia & 67,975 & 54,9 & - \\
\hline \multirow{2}{*}{ NIR $_{0,05}$} & Odmiana & 2,0 \\
& Roślina ochronna & 6,7 \\
& Odmiana $\times$ roślina ochronna & r.n. \\
\hline
\end{tabular}

Tabela 3. Wysokość osadzenia pierwszego strąka soi (cm)

\begin{tabular}{|l|c|c|c|}
\hline \multirow{2}{*}{ Gatunek rośliny ochronnej } & \multicolumn{2}{|c|}{ Odmiana soi } & \multirow{2}{*}{ Średnia } \\
\cline { 2 - 3 } & 'Mavka' & 'Annushka' & \\
\hline Kontrola w siewie czystym & 13,2 & 15,6 & 14,4 \\
Rzodkiew oleista & 16,1 & 16 & 16,05 \\
Gorczyca biała & 14,6 & 15,1 & 14,85 \\
Len oleisty & 13,7 & 14,6 & 14,15 \\
Średnia & 14,4 & 15,325 & - \\
\hline \multirow{2}{*}{ NIR $_{0,05}$} & Odmiana & 0,22 \\
& Roślina ochronna & 1,13 \\
& Odmiana $\times$ roślina ochronna & 1,22 \\
\hline
\end{tabular}

Stwierdzono istotny wpływ gatunku rośliny ochronnej na ilość produktywnych strąków zawiązanych na roślinach soi. Najwięcej strąków produktywnych obu odmian soi, znajdowało się na roślinach pochodzących z poletek, na których 
soja była uprawiana wraz z lnem oleistym. Istotnie więcej strąków wytworzyły rośliny soi odmiany 'Anushka' (tab. 4).

Istotnie największą masą 1000 nasion cechowała się odmiana 'Mavka'. Nasiona soi zebrane $\mathrm{z}$ obiektów, gdzie soję uprawiano $\mathrm{z}$ roślinami ochronnymi, charakteryzowały się istotnie mniejszą MTN niż te z obiektów kontrolnych (tab. 5).

Istotnie większą zawartość tłuszczu surowego odnotowano w nasionach soi odmiany 'Mavka'. Największą zawartość tłuszczu w nasionach soi odnotowano w jej uprawie współrzędnej wraz z lnem oleistym (tab. 6).

Tabela 4. Liczba strąków soi (szt. · roślina ${ }^{-1}$ )

\begin{tabular}{|l|c|c|c|}
\hline \multirow{2}{*}{ Gatunek rośliny ochronnej } & \multicolumn{2}{|c|}{ Odmiana soi } & \multirow{2}{*}{ Średnia } \\
\cline { 2 - 3 } & 'Mavka' & 'Annushka' & \\
\hline Kontrola w siewie czystym & 5 & 5 & 5 \\
Rzodkiew oleista & 3 & 4 & 4 \\
Gorczyca biała & 3 & 4 & 4 \\
Len oleisty & 6 & 5 & 6 \\
Średnia & 4 & 5 & - \\
\hline \multirow{2}{*}{ NIR $_{0,05}$} & Odmiana & r.n. \\
& Roślina ochronna & 1,58 \\
& Odmiana $\times$ roślina ochronna & 1,83 \\
\hline
\end{tabular}

Tabela 5. Masa tysiąca nasion soi (g)

\begin{tabular}{|l|c|c|c|}
\hline \multirow{2}{*}{ Gatunek rośliny ochronnej } & \multicolumn{2}{|c|}{ Odmiana soi } & \multirow{2}{*}{ Średnia } \\
\cline { 2 - 3 } & 'Mavka' & 'Annushka' & \\
\hline Kontrola w siewie czystym & 174,53 & 152,23 & 163,38 \\
Rzodkiew oleista & 169,33 & 150,10 & 159,72 \\
Gorczyca biała & 169,20 & 154,33 & 161,77 \\
Len oleisty & 173,23 & 153,13 & 163,18 \\
Średnia & 171,57 & 152,45 & - \\
\hline \multirow{2}{*}{ NIR $_{0,05}$} & Odmiana & 2,25 \\
& Roślina ochronna & 0,22 \\
& Odmiana $\times$ roślina ochronna & 2,61 \\
\hline
\end{tabular}


Tabela 6. Zawartość tłuszczu surowego w nasionach soi (\%)

\begin{tabular}{|l|c|c|c|}
\hline \multirow{2}{*}{ Gatunek rośliny ochronnej } & \multicolumn{2}{|c|}{ Odmiana soi } & \multirow{2}{*}{ Średnia } \\
\cline { 2 - 3 } & 'Mavka' & 'Annushka' & \\
\hline Kontrola w siewie czystym & 21,13 & 19,63 & 20,38 \\
Rzodkiew oleista & 20,37 & 19,10 & 19,74 \\
Gorczyca biała & 20,60 & 19,07 & 19,84 \\
Len oleisty & 21,40 & 19,77 & 20,59 \\
Średnia & 20,88 & 19,39 & - \\
\hline \multirow{2}{*}{ NIR $_{0,05}$} & Odmiana & 0,22 \\
& Roślina ochronna & 0,48 \\
& Odmiana $\times$ roślina ochronna & r.n. \\
\hline
\end{tabular}

Soja odmiany 'Mavka' charakteryzowała się istotnie wyższą zawartością białka w stosunku do odmiany 'Annushka'. Dodatkowo zaznaczyła się wyraźna tendencja występowania większej zawartości białka ogólnego w nasionach odmiany 'Mavka' pochodzącej z uprawy współrzędnej wraz z gorczycą białą, Inem oleistym oraz z obiektu kontrolnego (tab. 7).

Istotnie większą powietrznie suchą masę chwastów stwierdzono w obiektach kontrolnych w porównaniu z obiektami, w których soję uprawiano współrzędnie wraz z roślinami ochronnymi. W obiekcie kontrolnym, gdzie wysiewano odmianę 'Mavka', poziom zachwaszczenia łanu, mierzony suchą masą chwastów, był mniejszy niż w kombinacji z odmianą 'Anushka' (tab. 8).

Tabela 7. Zawartość białka w nasionach soi (\%)

\begin{tabular}{|l|c|c|c|}
\hline \multirow{2}{*}{ Gatunek rośliny ochronnej } & \multicolumn{2}{|c|}{ Odmiana soi } & \multirow{2}{*}{ Średnia } \\
\cline { 2 - 3 } & 'Mavka' & 'Annushka' & \\
\hline Kontrola w siewie czystym & 38,60 & 36,17 & 37,39 \\
Rzodkiew oleista & 37,93 & 35,63 & 36,78 \\
Gorczyca biała & 38,83 & 35,50 & 37,17 \\
Len oleisty & 39,33 & 35,97 & 37,65 \\
Średnia & 38,67 & 35,82 & - \\
\hline \multirow{2}{*}{ NIR $_{0,05}$} & Odmiana & 0,68 \\
& Roślina ochronna & 0,48 \\
& Odmiana $\times$ roślina ochronna & r.n. \\
\hline
\end{tabular}


Tabela 8. Powietrznie sucha masa chwastów $\left(\mathrm{g} \cdot \mathrm{m}^{-2}\right)$

\begin{tabular}{|l|c|c|c|}
\hline \multirow{2}{*}{ Gatunek rośliny ochronnej } & \multicolumn{2}{|c|}{ Odmiana soi } & \multirow{2}{*}{ Średnia } \\
\cline { 2 - 3 } & 'Mavka' & 'Annushka' & \\
\hline Kontrola w siewie czystym & 364,00 & 388,33 & 376,17 \\
Rzodkiew oleista & 172,67 & 179,67 & 176,17 \\
Gorczyca biała & 185,67 & 177,00 & 181,34 \\
Len oleisty & 172,33 & 172,33 & 172,33 \\
Średnia & 223,67 & 229,33 & - \\
\hline \multirow{2}{*}{ NIR $_{0,05}$} & Odmiana & 4,36 \\
& Roślina ochronna & 23,14 \\
& Odmiana $\times$ roślina ochronna & 24,86 \\
\hline
\end{tabular}

Tabela 9. Liczba chwastów (szt. $\cdot \mathrm{m}^{2}$ )

\begin{tabular}{|l|c|c|c|}
\hline \multirow{2}{*}{ Gatunek rośliny ochronnej } & \multicolumn{2}{|c|}{ Odmiana soi } & \multirow{2}{*}{ Średnia } \\
\cline { 2 - 3 } & 'Mavka' & 'Annushka' & \\
\hline Kontrola w siewie czystym & 40 & 40 & 40 \\
Rzodkiew oleista & 23 & 21 & 22 \\
Gorczyca biała & 22 & 18 & 20 \\
Len oleisty & 21 & 20 & 20 \\
Średnia & 26,5 & 24,75 & - \\
\hline \multirow{2}{*}{ NIR $_{0,05}$} & Odmiana & r.n. \\
& Roślina ochronna & 3,6 \\
& Odmiana $\times$ roślina ochronna & r.n. \\
\hline
\end{tabular}

Liczba chwastów ogółem określana przed zbiorem soi była istotnie większa w obiektach kontrolnych niż w obiektach, w których soję uprawiano współrzędnie wraz z roślinami ochronnymi (tab. 9).

\section{Dyskusja}

W przeprowadzonym doświadczeniu oceniano wpływ uprawy współrzędnej z roślinami ochronnymi na ilość i jakość plonu soi oraz zachwaszczenie jej łanu. W badaniach Żabińskiego [2008] nad uprawą współrzędną soczewicy z komponentem podporowym najwyższe plony stwierdzono w uprawie z gryką. Podobną zależność wykazali Kraska i in. [2015]. Autorzy ci, wysiewając soczewicę współrzędnie z owsem siewnym, uzyskali większą wysokość osadzenia pierw- 
szego strąka rośliny motylkowatej. Wyniki tych badań znajdują również potwierdzenie w badaniach własnych. Zhang i Li [2003] stwierdzili, że uprawa współrzędna korzystnie wpływa na zwiększenie plonu obydwu komponentów uprawy współrzędnej. Jednak aby osiągnąć wymierne korzyści z takiej uprawy, należy odpowiednio dobrać gatunek rośliny pomocniczej uprawianej wspólnie $\mathrm{z}$ rośliną motylkowatą [Fujita $\mathrm{i}$ in. 1992].

Średnie plony soi uprawianej konwencjonalnie uzyskiwane $\mathrm{w}$ badaniach prowadzonych przez Szyrmer i Boros [1996] kształtowały się od 1,9 do 2,4 $\mathrm{t} \cdot \mathrm{ha}^{-1}$, w zależności od odmiany soi. Natomiast w przypadku uprawy współrzędnej najwyższy plon wynosił $773,33 \mathrm{~kg} \cdot \mathrm{ha}^{-1}$. Susza występująca $\mathrm{w}$ trakcie badań realizowanych w 2019 r. również przyczyniła się do zmniejszenia plonu oraz zawartości tłuszczu i białka w nasionach soi. Dowodem tego są badania Michałka i Borowskiego [2006] nad wpływem warunków suszowych na plonowanie oraz zawartość tłuszczu i białka.

Wyniki uzyskane w niniejszych badaniach dowodzą, że zawartość tłuszczu surowego i białka ogólnego w nasionach soi zależały od odmiany, jaką uprawiano. Taką zależność stwierdzili też Pisulewska i in. [1998]. W badaniach Kraski i in. [2018] stwierdzono, że uprawa współrzędna wpływa nie tylko na parametry jakościowe nasion roślin strączkowych, ale zmianom ulega także skład chemiczny.

Hruszka i Brzozowska [2008] dowiodły, że biologiczna ochrona przed zachwaszczeniem łanu jest mało efektywna. W przeprowadzonym doświadczeniu stwierdzono jednak, że zastosowanie uprawy współrzędnej wraz z odpowiednio dobranym komponentem znacząco zmniejszyło zachwaszczenie łanu obiektów niechronionych chemicznie. Stupnicka-Radzynkiewicz i in. [2004] uważają, że skład gatunkowy zachwaszczenia wywiera wpływ na zbiorowisko chwastów, gdyż poszczególne gatunki różnią się zdolnościami konkurencyjnymi w stosunku do rośliny uprawnej.

W badaniach Bujaka i in. [2001] liczba i powietrznie sucha masa chwastów w większym stopniu zależały od warunków atmosferycznych w kolejnych latach przebiegu doświadczenia niż zastosowanych układów uprawy współrzędnej.

Jak twierdzą Mickiewicz i Mickiewicz [2014], w perspektywie rozwoju gospodarstw ekologicznych uprawa współrzędna jest idealnym sposobem na zmniejszenie niekorzystnych skutków takiego systemu gospodarowania. Teoria ta znajduje potwierdzenie w pracy Wiecha $\mathrm{i}$ in. [2009] na temat wpływu infrastruktury ekologicznej na agrofagi i organizmy pożyteczne w uprawach warzyw.

\section{Wnioski}

1. Rośliny soi uprawiane współrzędnie charakteryzowały się tendencją do zwiększania wysokości zawiązywania pierwszych strąków. 
2. Niezależnie od innych czynników plon nasion odmiany 'Mavka' był istotnie wyższy od plonu nasion odmiany 'Annushka'. Natomiast niezależnie od odmiany największy plon nasion soi uzyskano w zasiewach z lnem oleistym.

3. Liczba strąków oraz masa tysiąca nasion były zależne od odmiany oraz rośliny uprawianej współrzędnie z soją.

4. Zawartość tłuszczu surowego i białka w nasionach soi była istotnie najwyższa w obiektach z lnem oleistym.

5. Opóźnione wschody spowodowane okresem suszy nasiliły występowanie chwastów, które miały niekorzystny wpływ na dalszy rozwój soi. Niezależnie od tego odnotowano istotnie mniejszą masę i liczbę chwastów we wszystkich obiektach uprawy współrzędnej w porównaniu z łanem soi wysiewanej bez rośliny ochronnej.

\section{Bibliografia}

Bobrecka-Jamro D., 1999. Soja. W: Z. Jasińska i A. Kotecki (red.), Szczegółowa uprawa roślin, t. 2. Wyd. AR, Wrocław, 111-121.

Bujak K., Jędruszczak M., Frant M., 2001. Sposób uprawy roli a zachwaszczenie łanu soi. Ann. UMCS, sec. E, Agricultura 56, 9-17.

Corre-Hellou G., Fustec J., Crozat Y., 2006. Interspecific competition for soil N and its interactions with $\mathrm{N}_{2}$ fixation, leaf expansion and crop growth in pea-barley intercrops. Plant Soil 282, 195-208. https://doi.org/10.1007/s11104-005-5777-4

Foroutan-pour K., Dutilleul P., Smith D.L., 1999. Soybean canopy development as affected by population density and intercropping with corn: fractal analysis in comparison with other quantitative approaches. Crop Sci. 39, 1784-1791.

Fujita K., Ofosu-Budu K.G., Ogata S., 1992. Biological nitrogen fixation in mixed legume-cereal cropping systems. Plant Soil 141(1-2), 155-175. https://doi.org/10.1007/BF00011315

Giller K.E., Beare M.H., Lavelle P., Izac M.N., Swift M.J., 1997. Agricultural intensification, soil biodiversity and agroecosystem function. Appl. Soil Ecol. 6, 3-16. https://doi.org/10.1016/S0929-1393(96)00149-7

Głowacka A., 2007. Wpływ współrzędnej uprawy pasowej na zachwaszczenie kukurydzy pastewnej. Acta Agrophys. 10(3), 573-582.

Griffon M., 1999. Développement durable et agriculture: la revolution doublement verte. Cah. Agric. 8, 259-267

Hauggaard-Nielsen H., Ambus P., Jensen E.S., 2001. Interspecific competition, N use and interference with weeds in pea-barley intercropping. Field Crop. Res. 70, 101-109. https://doi.org/10.1016/S0378-4290(01)00126-5

Hruszka M., Brzozowska I., 2008. Skuteczność chemicznych i proekologicznych sposobów regulacji zachwaszczenia w zmianowaniu. Acta Agrophys. 12(2), 347-355.

Khan Z.R., Ampong-Nyarko K., Chiliswa P., Hassanali A., Kimani S., Lwande W., Overholt W.A., Overholt W.A., Picketta J.A., Smart L.E., Woodcock C.M., 1997. Intercropping increases parasitism of pests. Sci. Corresp. 388, 631-632. https://doi.org/10.1038/41681

Kraska P., Andruszczak S., Staniak M., Kwiecińska-Poppe E., Różyło K., Rusecki H., 2018. Evaluation of chemical composition of lentil seeds in sole crop and row intercropped with naked oats in an organic farm. Appl. Ecol. Environ. Res. 16(2), 1855-1867. http://dx.doi.org/10.15666/aeer/1602_18551867

Kraska P., Pałys E., Kiecana I., Andruszczak S., Cegiełko M., Kwiecińska-Poppe E., Różyło K., Zimowska B., Krusińska B., Gierasimiuk P., 2015. „Warzywnictwo (w tym uprawa ziół) metodami ekologicznymi: określenie dobrych praktyk ochrony przed szkodnikami i chorobami w ekolo- 
gicznej produkcji ziół i warzyw”. Zrealizowano na podstawie decyzji Ministra Rolnictwa i Rozwoju Wsi z dnia 15 października 2015 r. o nr HORre-msz-0780-13/15 (458). https://www.up.lublin.pl/files/agrobio/katedra-ekologii-rolniczej/badania/raport_z_badan_2015_ostateczna.pdf [dostęp: 15.10.2015].

Liebman M., Dyck E., 1993. Crop rotation and intercropping strategies for weed management. Ecol. Appl. 3, 92-122. https://doi.org/10.2307/1941795

Liu J., Yang C., Zhang Q., Lou Y., Wu H., Deng J., Yang F., Yang W. 2016. Partial improvements in the flavor quality of soybean seeds using intercropping systems with appropriate shading. Food Chem. 207, 107-114. https://doi.org/10.1016/j.foodchem.2016.03.059

Michałek S., Borowski E., 2006. Plonowanie oraz zawartość tłuszczu, kwasów thuszczowych i białka w nasionach krajowych odmian soi w warunkach suszy. Acta Agrophys. 8(2), 459-471.

Mickiewicz A., Mickiewicz B., 2014. Stosowanie środków produkcji w świetle nowych zasad integrowania ochrony roślin. Rocz. Nauk. Stow. Ekon. Rol. Agrobiz. 16(5), 160-168. https://doi.org/10.22004/ag.econ.205242

Muoneke C.O., Ogwuche M.A.O., Kalu B.A., 2007. Effect of maize planting density on the performance of maize/soybean intercropping system in guinea savannah agroecosystem. Afr. J. Agric. Res. 2, 667-677.

Pisulewska E., Lorenc-Kozik A., Borowiec F., 1998. Porównanie plonu nasion oraz zawartości thuszczu i kwasów tłuszczowych w krajowych odmianach soi. Rośl. Oleiste/Oilseed Crops 19(1), 97-104.

Robak J., Wiech K., 1998. Choroby i szkodniki warzyw. Plantpress, Kraków, 311.

Sartorius G., 1993. Uprawa współrzędna i płodozmian. Oficyna Wydawnicza Multico, Warszawa, $10-11$.

Stupnicka-Rodzynkiewicz E., Stępnik K., Dąbkowska T., Labza T., 2004. Różnorodność zbiorowisk chwastów w uprawach zbóż w Beskidach. Fragm. Agron. 21(4), 45-54.

Szyrmer J., Boros L., 1996. Postęp w hodowli i wprowadzenie do uprawy nowych odmian soi. Biul. Inst. Hod. Aklim. Rośl. 198, 5-12.

Tilman D., Cassman K., Matson P., Naylor R., Polasky S., 2002. Agricultural sustainability and intensive production practices. Nature 418, 671-677. https://doi.org/10.1038/nature01014

Trenbath B.R., 1993. Intercropping for the management of pests and diseases. Field Crop. Res. 34, 381-405. https://doi.org/10.1016/0378-4290(93)90123-5

Vandermeer J., Van Noordwijk M., Anderson J., Ong C., Perfecto I. 1998. Global change and multi-species ecosystems: concepts and issues. Agr. Ecosyst. Environ. 67, 1-22. https://doi.org/10.1016/S0167-8809(97)00150-3

Wiech G., Wnuk A., Wojciechowicz-Żytko E., Jankowska B., 2009. Wpływ infrastruktury ekologicznej na agrofagi i organizmy pożyteczne w uprawach warzyw. Progr. Plant Prot. 49(3), $1125-1132$

Wiech K., 2000. Uprawa współrzędna w integrowanej produkcji warzyw. Ochr. Rośl., 9(44), 33-34.

Zhang F., Li L., 2003. Using competitive and facilitative interactions in intercropping systems enhances crop productivity and nutrient-use efficiency. Plant Soil, 248(1-2), 305-312. https://doi.org/10.1023/A:1022352229863

Żabiński A., 2008. Wpływ uprawy współrzędnej soczewicy z rośliną podporową na plonowanie i cechy roślin tego gatunku istotne podczas zbioru kombajnowego. Inż. Rol. 12, 283-290. 
Aleksander Chudy

\title{
Akumulatory litowo-jonowe w samochodach elektrycznych - regeneracja, zastosowanie wtórne i recykling
}

Lithium-ion batteries in electric vehicles - regeneration, re-using and recycling

\begin{abstract}
Wstęp
Litowo-jonowe ogniwa galwaniczne są najczęściej wybieraną technologią w akumulatorach służących do wielokrotnego ładowania, ponieważ zapewniają bardzo dużą objętościową i wagową gęstość energii w porównaniu z pozostałymi rozwiązaniami [Meister $\mathrm{i}$ in. 2016, Winter i in. 2018]. Rozwój technologii ogniw litowo-jonowych był początkowo napędzany głównie przez przemysł elektroniki przenośnej. Od czasu wprowadzenia tych ogniw na rynek przez Sony w 1991 r. gęstość energii ogniwa litowo-jonowego zwiększyła się ponad dwukrotnie, ze $100 \mathrm{Wh} / \mathrm{kg}(250 \mathrm{Wh} / \mathrm{l})$ do $250 \mathrm{Wh} / \mathrm{kg}(600 \mathrm{Wh} / \mathrm{l})$, głównie dzięki ulepszaniu właściwości elektrod. Zwiększenie gęstości energii ogniw litowo-jonowych umożliwiło miniaturyzację urządzeń elektronicznych i pojawienie się smartfonów i tabletów [Chen X. i Vereecken 2019].

Pojazdy napędzane silnikami spalinowymi zaczęły wzbudzać wiele kontrowersji ze względu na ich wpływ na klimat. W ostatnich latach wysiłki na rzecz ograniczenia skutków zmian klimatycznych i lokalnego zanieczyszczenia powietrza doprowadziły do szybkiego postępu w rozwoju pojazdów elektrycznych wykorzystujących akumulatory litowo-jonowe (ang. li-ion batteries, LIBs) [Tong $\mathrm{i}$ in.i in. 2019]. Ulepszenia technologii LIBs w ciągu ostatnich 10 lat także spowodowały rozwój i wzrost popularności tego typu pojazdów, głównie samochodów hybrydowych oraz elektrycznych typu plug-in, które niedługo będą odpowiadały za ponad połowę całkowitej produkcji LIBs. Dla sektora elektromobilności gęstość energii i gęstość mocy są głównymi czynnikami napędzającymi dalszy rozwój LIBs. Żywotność, koszt, wydajność, gęstość energii i mocy oraz bezpieczeństwo są powszechnie uznawane za sześć najważniejszych aspektów dotyczących akumulatorów stosowanych w pojazdach elektrycznych [Blomgren 2017, Chen X. i Vereecken 2019, Chudy 2019].

W artykule dokonano przeglądu literatury dotyczącej metod recyklingu oraz ponownego wykorzystania LIBs stosowanych wcześniej w samochodach elek-
\end{abstract}

\footnotetext{
${ }^{1}$ Politechnika Lubelska, Katedra Elektrotechniki i Elektrotechnologii, a.chudy@pollub.pl
} 
trycznych. Omówiono potencjalne zastosowanie LIBs wycofanych z eksploatacji. Wzięto pod uwagę bieżący stan recyklingu LIBs, koncentrując się na procesach pirometalurgicznych, hydrometalurgicznych i metodach bezpośrednich recyklingu. W artykule przeanalizowano literaturę pokrewną i prezentacje branżowe, zapewniając wgląd w obecną sytuację na rynku LIBs w sektorze elektromobilności.

\section{Akumulatory litowo-jonowe w pojazdach elektrycznych}

Istnieje wiele różnych rodzajów akumulatorów, ale tylko niektóre nadają się do wykorzystania $\mathrm{w}$ sektorze transportowym. Obecnie można wyróżnić trzy główne typy akumulatorów odpowiednich do zastosowania w pojazdach. Są to akumulatory kwasowo-ołowiowe, niklowe oraz bazujące na licie. Na rynku istnieją również akumulatory sodowo-siarkowe (NaS), metalowo-powietrzne i przepływowe, jednak są one dużo rzadziej stosowane [Li i in. 2019, Miao i in. 2019].

W samochodach elektrycznych najczęściej stosowane są LIBs ze względu na swoje właściwości (przede wszystkim ze względu na dużą gęstość energii) i można zasadniczo scharakteryzować je jako systemy magazynowania energii, które opierają się na reakcjach wprowadzania (ang. insertion reactions) z obu elektrod, w których jony litu działają jako nośniki ładunku elektrycznego [Horiba 2014]. Biorąc pod uwagę tę szeroką definicję, istnieje szereg ogniw o różnym składzie

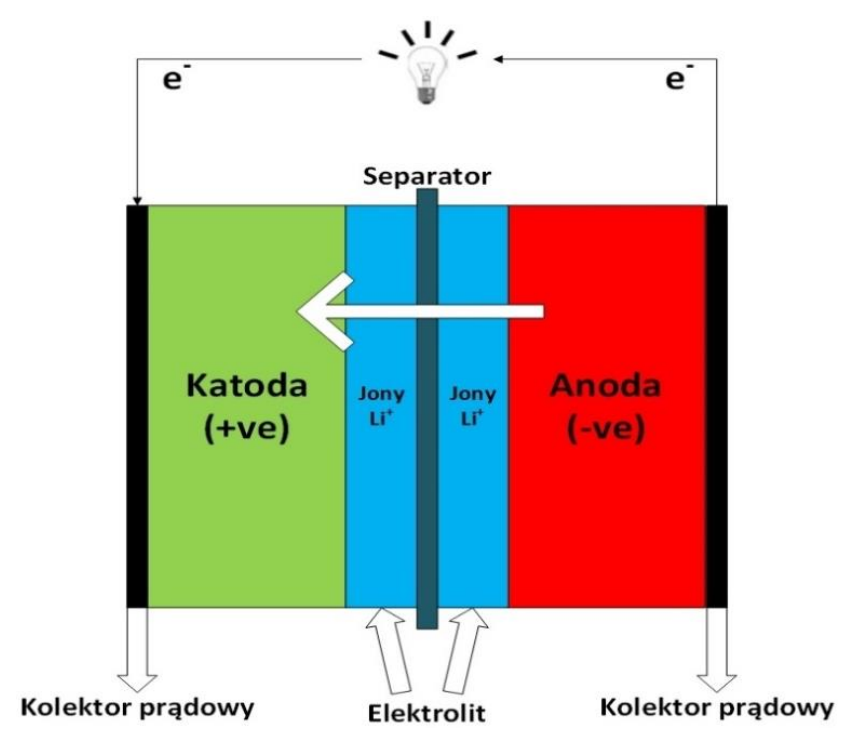

Rys. 1. Schemat ideowy akumulatora litowo-jonowego przedstawiający elektrody dodatnie i ujemne, elektrolit oraz porowatą membranę (separator), mającą zapobiegać bezpośredniemu kontaktowi między dwiema elektrodami 
chemicznym, które tworzą rodzinę akumulatorów litowo-jonowych. W większości LIBs elektroda ujemna wykonana jest głównie z węgla (np. grafitu) lub tytanianu litu $\left(\mathrm{Li}_{4} \mathrm{Ti}_{5} \mathrm{O}_{12}\right)$. Elektrolit różni się $\mathrm{w}$ zależności od wyboru materiałów elektrod, ale zazwyczaj składa się z mieszaniny soli litu (np. LiPF 6 ) i rozpuszczalnika organicznego (np. węglanu dietylu), aby umożliwić przenoszenie jonów. Elektrolit jest istotną częścią akumulatora, ponieważ zapewnia przewodnictwo jonowe i umożliwia jonom $\mathrm{Li}^{+}$przemieszczanie się między dwiema elektrodami, przy czym nie jest jednocześnie przewodnikiem elektronowym. Istnieją dwie główne klasy elektrolitów: płynna (wodna oraz organiczna) i stała (polimerowa oraz ceramiczna). Membrana oddzielająca służy do przepuszczania jonów litu między elektrodami i jednocześnie zapobiega zwarciu wewnątrz ogniwa [Hannan $\mathrm{i}$ in. 2018]. Koncepcję akumulatora litowo-jonowego działającego jako źródło energii (urządzenie galwaniczne) przedstawiono na rysunku 1. Gdy akumulator działa jak ogniwo galwaniczne, elektrony przemieszczają się od elektrody ujemnej do kolektora prądowego, a dalej wykonują pracę (obciążenie), następnie przemieszczają się przez drugi kolektor prądowy do elektrody dodatniej. Jednocześnie jony Li+ przemieszczają się od elektrody ujemnej przez elektrolit do elektrody dodatniej, aby zachować elektroneutralność. W trybie ładowania (tj. jako ogniwo elektrolityczne) przepływy elektronów i jonów $\mathrm{Li}^{+}$są odwrócone [Miao i in. 2019].

\section{Perspektywy dla LIBs u kresu eksploatacji}

Oczekuje się, że pojazdy elektryczne zmniejszą wpływ transportu na środowisko i zniwelują problemy związane z zanieczyszczeniem, jednak wiele materiałów użytych $w$ akumulatorach jest toksycznych i rzadkich. Wydłużenie cyklu życia baterii ma zatem kluczowe znaczenie dla poprawy wkładu pojazdów elektrycznych w ogólny zrównoważony rozwój ukierunkowany na gospodarkę niskoemisyjną. Miliony pojazdów są wyposażone w akumulatory litowo-jonowe lub bezpośrednio przez nie zasilane. Rosnące wykorzystanie tego rodzaju akumulatorów w samochodach elektrycznych wprowadzi dużą liczbę zużytych akumulatorów w ciągu 8-10 lat. Oczekuje się, że do 2025 r. 250 tys. ton LIBs wykorzystywanych w samochodach elektrycznych osiągnie koniec okresu eksploatacji. W tym kontekście koniec żywotności oznacza, że akumulatory nie są już uważane za przydatne w pojeździe, ale nadal posiadają $70-80 \%$ pojemności. Możliwość ponownego wykorzystania tych akumulatorów, a dopiero potem recyklingu, może prowadzić do korzystnych rozwiązań w zakresie zrównoważonego rozwoju [Olsson $\mathrm{i}$ in. 2018, Winslow $\mathrm{i}$ in. 2018, Chen M. i in. 2019]. Wymagane jest właściwe postępowanie $\mathrm{z}$ akumulatorami pojazdów wycofanych z eksploatacji, dlatego należy rozważyć wiele opcji. Rysunek 2 przedstawia łańcuch wartości LIBs stosowanych w samochodach elektrycznych. Rozpoczyna się on od projektowania i produkcji akumulatora. Gdy akumulator nie nadaje się już do 


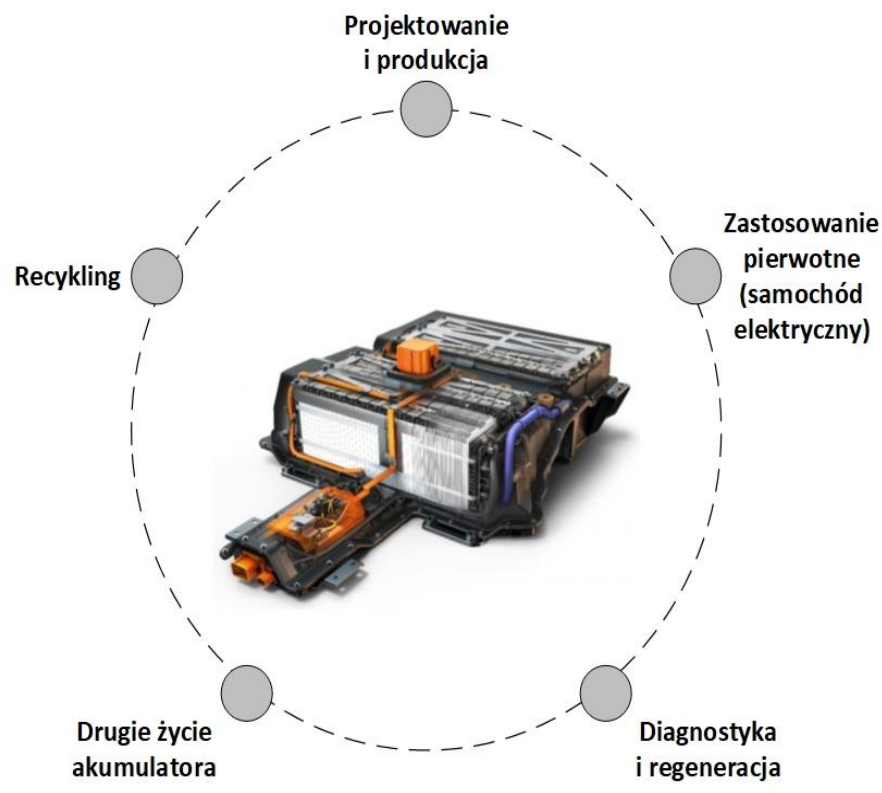

Rys. 2. Łańcuch wartości akumulatorów litowo-jonowych stosowanych w samochodach elektrycznych

pierwotnego zastosowania, sprawdzane są jego ogólny stan i pojemność, tak aby stwierdzić, czy można zastosować go w innym pojeździe, rozwiązaniu stacjonarnym, czy też od razu musi zostać poddany recyklingowi. Jeśli możliwe jest „drugie życie” akumulatora, zostaje on odnowiony. W zależności od akumulatora i potencjalnego ponownego zastosowania regeneracja może obejmować różne procesy.

\section{Regeneracja}

Regeneracja LIBs obejmuje diagnostykę, częściowy demontaż akumulatorów, wymianę uszkodzonych ogniw lub modułów w akumulatorach, a następnie ponowny montaż. W odniesieniu do akumulatorów samochodów elektrycznych wymagane jest, aby LIBs charakteryzowały się akceptowalną jakością, którą określa SOH (ang. state-of-health, jest to kryterium jakości odzwierciedlające ogólny stan akumulatora, lub ogniwa, i jego zdolność do zapewnienia określonej sprawności w porównaniu z nowym akumulatorem), i spełniały wszystkie określone przez producentów oryginalnego wyposażenia wymagania dotyczące mocy, energii i żywotności [Kwade i in. 2018, Olsson i in. 2018, Chen M. i in. 2019].

Akumulatory zasadniczo nie nadają się do zastosowania ich w samochodach elektrycznych, gdy tracą od 20 do $30 \%$ pojemności. Czas, po jakim się to stanie, zależy od wielu czynników, takich jak: zachowanie konsumenta podczas ładowania i rozładowywania oraz styl jazdy, specyfikacja techniczna akumulatora, 
(w tym wydajność zespołu napędowego), klimat (szczególne narażenie na szybszą degradację w wysokich lub niskich temperaturach). Badania dotyczące degradacji LIBs pokazują, że pojemność akumulatora maleje liniowo do $80 \%$, a następnie dzieje się to szybciej [Hawkins i in. 2012, Faria i in. 2014, Schuster i in. 2015]. Diagnostyka akumulatora może wykazać, że tylko niewielki procent ogniw nie utrzymał wymaganej pojemności i porzucenie całego akumulatora oznacza niepełne zużycie. Ideą regeneracji jest wymiana gorszych ogniw lub modułów w zestawach i użycie zregenerowanych akumulatorów w pojazdach elektrycznych.

\section{Ponowne wykorzystanie akumulatorów litowo-jonowych z samochodów elektrycznych}

W przypadku, gdy akumulator nie jest w stanie utrzymać pożądanej pojemności, a regeneracja wydaje się nieekonomiczna, zmiana przeznaczenia staje się bardziej opłacalną ścieżką. Wymaga ona nie tylko wymiany uszkodzonych ogniw lub modułów, ale także ponownej konfiguracji modułów lub pakietów, w tym skonfigurowania nowych systemów zarządzania akumulatorami, w celu dostosowania ich do zastosowań innych niż samochody elektryczne. Na podstawie literatury dotyczącej LIBs można stwierdzić, że istnieje wiele możliwości ich ponownego zastosowania, które wymieniono w tabeli 1. Zainteresowanie wykorzystaniem akumulatorów do magazynowania energii elektrycznej ze źródeł odnawialnych zyskuje na popularności. Istnieje też kilka projektów demonstracyjnych, w których do tego celu wykorzystywane są akumulatory wtórne. Innym obszarem rosnącego zainteresowania jest stosowanie akumulatorów w celu zmniejszenia

Tabela 1. „Drugie życie” LIBs - potencjalne zastosowania [Olsson i in. 2018, DeRousseau i in. 2017]

\begin{tabular}{|c|c|c|}
\hline Zastosowanie & Podmiot & Opis \\
\hline $\begin{array}{l}\text { Magazynowanie energii elek- } \\
\text { trycznej pochodzącej ze źródeł } \\
\text { odnawialnych }\end{array}$ & $\begin{array}{l}\text { Gospodarstwa domowe, wła- } \\
\text { ściciele nieruchomości }\end{array}$ & $\begin{array}{l}\text { Mała lub duża skala, off-grid } \\
\text { lub on-grid }\end{array}$ \\
\hline Ścinanie szczytów & Przemysł & $\begin{array}{l}\text { Dążenie do wyrównania } \\
\text { profilu obciążenia dobowego }\end{array}$ \\
\hline $\begin{array}{l}\text { Ładowanie samochodu elek- } \\
\text { trycznego właściciela o niż- } \\
\text { szych wymaganiach }\end{array}$ & $\begin{array}{l}\text { Właściciele samochodów elek- } \\
\text { trycznych oraz sieci elektroe- } \\
\text { nergetyczne }\end{array}$ & $\begin{array}{l}\text { Zmniejszenie zapotrzebowa- } \\
\text { nia na energię elektryczną } \\
\text { z sieci podczas ładowania }\end{array}$ \\
\hline $\begin{array}{l}\text { Poprawa stabilności sieci } \\
\text { elektroenergetycznej }\end{array}$ & Sieci elektroenergetyczne & $\begin{array}{l}\text { Zamiast modernizacji sieci } \\
\text { oraz w celu uniknięcia wa- } \\
\text { hań wartości parametrów } \\
\text { jakości energii }\end{array}$ \\
\hline Akumulator jako rezerwa & $\begin{array}{l}\text { Przemysł, właściciele nierucho- } \\
\text { mości }\end{array}$ & W przypadku awarii \\
\hline Handel energią elektryczną & Przedsiębiorstwa energetyczne & $\begin{array}{l}\text { Np. farma akumulatorów } \\
\text { służąca do handlu energią } \\
\text { elektryczną }\end{array}$ \\
\hline Napędzanie pojazdów & Producenci pojazdów & Np. wózki widłowe \\
\hline
\end{tabular}


zapotrzebowania na moc, a tym samym kosztów [DeRousseau i in. 2017]. Używany wcześniej akumulator, który utracił swoje pierwotne parametry może być uważany za wystarczająco dobry produkt dla niektórych klientów, na przykład dla właścicieli samochodów elektrycznych, którzy nie mają wysokich wymagań odnośnie do zasięgu, czy też dla właścicieli gospodarstw domowych (magazynowanie energii elektrycznej pochodzącej z odnawialnych źródeł energii).

Zmiana przeznaczenia akumulatora wymaga wykonalnej ekonomii i uzasadnienia biznesowego. Testowanie, sortowanie i przepakowywanie to główne czynniki wpływające na cenę tego rozwiązania.

Klienci zazwyczaj intuicyjnie nie ufają akumulatorom o obniżonej wydajności, ale można próbować tego uniknąć, jeśli producent zapewni gwarancję, doradztwo, instalację i konserwację akumulatorów o zmienionym przeznaczeniu.

\section{Recykling akumulatorów litowo-jonowych}

Technologia LIBs stoi w obliczu większej liczby wyzwań związanych z recyklingiem niż jej poprzednicy. Mnogość związków chemicznych stosowanych w dzisiejszych akumulatorach sprawia, że recykling jest coraz bardziej złożony, co stwarza przeszkody techniczne i ekonomiczne, którymi należy się zająć, aby umożliwić wydajny recykling na dużą skalę. Po pierwsze, pakiety LIBs są skomplikowanymi strukturami, składającymi się z wielu modułów, w których liczne ogniwa są łączone w różnych szeregowo-równoległych konfiguracjach (spawanie, ultrakompresja i łączenie mechaniczne są powszechnymi technikami łączenia stosowanymi w ogniwach, modułach i pakietach LIBs). Architektury pakietów LIBs w zależności od producenta znacznie się od siebie różnią. W komercyjnych LIBs jest stosowanych co najmniej pięć rodzajów katod o różnym składzie chemicznym, a wiele LIBs wykorzystywanych w samochodach elektrycznych bazuje również na mieszanych katodach (mieszanina dwóch lub trzech materiałów katodowych w jednym ogniwie). Wysiłki badawcze skierowane obecnie na materiały katodowe z pewnością doprowadzą do jeszcze bardziej zmiennego łańcucha dostaw dla przetwórców, a to spowoduje, że wartość odzyskiwalna będzie niska i niespójna.

Można wyróżnić trzy metody recyklingu LIBs [Zeng i in. 2014, Heelan i in. 2016, Olsson i in. 2018]:

a) pirometalurgiczne

Pirometalurgia to proces obróbki termicznej, który obejmuje pirolizę, wytapianie, destylację i rafinację. Akumulatory są rozdrabniane i powoli ogrzewane, po czym tworzywa sztuczne i rozpuszczalniki są spalane podczas pirolizy, w której materiał organiczny ulega rozkładowi. Pozostała część jest wytapiana w piecu i łączona $\mathrm{z}$ wapnem, aby wytworzyć żużel. Metale są następnie oddzielane przez destylację. Odzyskuje się nikiel, kobalt i miedź, podczas gdy lit i mangan zwykle pozostają w żużlu. $\mathrm{Z}$ tym procesem związane są stosunkowo udane modele biznesowe ze względu na wysoką zawartość kobaltu w LIBs stosowanych w przenośnej elektronice. W akumulatorach stosowanych w sektorze elektromo- 
bilności wykazywane są jednak tendencje do obniżania zawartości kobaltu, przez co te modele biznesowe staną się mniej atrakcyjne. Głównymi zaletami procesów pirometalurgicznych są: dojrzałość metody, brak konieczności sortowania i redukcji wielkości (mieszanina LIBs i akumulatorów NiMH może być poddana recyklingowi). Główne wady to emisja $\mathrm{CO}_{2} \mathrm{i}$ wysokie zużycie energii podczas procesu wytapiania, wymóg dalszej obróbki stopu, co zwiększa całkowity koszt recyklingu oraz nieodzyskiwanie wielu materiałów w LIB (np. tworzyw sztucznych, grafitu i aluminium).

b) hydrometalurgiczne

W tym procesie odzyskiwanie materiału osiąga się za pomocą chemii wodnej, poprzez ługowanie kwasami (lub zasadami), a następnie zatężanie i oczyszczanie. W przypadku LIBs jony $\mathrm{w}$ roztworze są oddzielane $\mathrm{z}$ zastosowaniem różnych technologii (wymiana jonowa, ekstrakcja rozpuszczalnikiem, wytrącanie chemiczne, elektroliza itp.) i wytrącane jako różne związki [Chagnes i Pospiech 2013]. Głównymi zaletami procesu hydrometalurgicznego są: uzyskiwanie materiałów o wysokiej czystości, odzyskiwanie większości składników LIBs, praca $\mathrm{w}$ niskiej temperaturze, niższa emisja $\mathrm{CO}_{2} \mathrm{w}$ porównaniu $\mathrm{z}$ procesem pirometalurgicznym. Do głównych wad można zaliczyć: potrzebę sortowania, która wymaga zwiększenia kosztów, trudność oddzielenia niektórych pierwiastków ( $\mathrm{Co}, \mathrm{Ni}, \mathrm{Mn}, \mathrm{Fe}, \mathrm{Cu}$ i $\mathrm{Al})$ w roztworze, ze względu na ich podobne właściwości.

c) mechaniczne (recykling bezpośredni)

W tym procesie składniki baterii są oddzielane, przede wszystkim metodami separacji fizycznej, magnetycznej i umiarkowanej obróbki termicznej, aby uniknąć rozpadu chemicznego materiałów aktywnych, które są głównym celem odzysku.

W większości przypadków stosuje się kombinację tych metod.

\section{Wnioski}

Trzydzieści lat po komercjalizacji LIBs można bez wątpienia uznać, że stały się jedną z przełomowych technologii. Komercjalizacja LIBs wpłynęła na popularyzację elektryfikacji pojazdów i stacjonarnego magazynowania energii elektrycznej w zastosowaniach elektroenergetycznych [Winter i in. 2018].

Każdy proces pirometalurgiczny, hydrometalurgiczny i recykling bezpośredni mają swoje zalety i wady. Zarówno procesy pirometalurgiczne, jak i hydrometalurgiczne zostały skomercjalizowane, a ich modele biznesowe zależą w dużej mierze od wysokiego stężenia kobaltu w LIBs stosowanych w przenośnych urządzeniach elektronicznych. Jednakże te modele biznesowe mogą być niewystarczające w przypadku akumulatorów stosowanych w samochodach elektrycznych, ponieważ tego typu akumulatory mają coraz niższe zawartości kobaltu. Procesy recyklingu bezpośredniego pozostają na poziomie laboratoryjnym i wymagają dalszego rozwoju w celu uzyskania znaczącego wpływu. W związku z tym po- 
trzeba rozwoju elastycznych technik przetwarzania w celu wydobycia jak największej wartości materiałowej z obecnych i przyszłych generacji akumulatorów ma zasadnicze znaczenie dla zrównoważonego rozwoju pojazdów elektrycznych. Niestety żaden z powyższych procesów recyklingu nie stanowi obecnie ekonomicznego rozwiązania i potrzebne są lepsze technologie recyklingu. Powszechnie przyjmuje się, że model, w którym uzyskana wartość przekracza koszty recyklingu, jest niezbędnym czynnikiem wydajnego selekcjonowania, a tym samym zrównoważonego recyklingu w obiegu zamkniętym.

\section{Bibliografia}

Blomgren G.E., 2017. The Development and Future of Lithium Ion Batteries. J. Electrochem. Soc. 164(1), A5019-A5025. https://doi.org/10.1149/2.0251701jes

Chagnes A., Pospiech B., 2013. A brief review on hydrometallurgical technologies for recycling spent lithium-ion batteries. J. Chem. Technol. Biotechnol. 88(7), 1191-1199. https://doi.org/10.1002/jctb.4053

Chen M., Ma X., Chen B., Arsenault R., Karlson P., Simon N., Wang Y., 2019. Recycling End-ofLife Electric Vehicle Lithium-Ion Batteries. Joule 3(11), 2622-2646. https://doi.org/10.1016/j.joule.2019.09.014

Chen X., Vereecken P.M., 2019. Solid and Solid- Like Composite Electrolyte for Lithium Ion Batteries: Engineering the Ion Conductivity at Interfaces. Adv. Mater. Interfaces 6(1), 1800899. https://doi.org/10.1002/admi.201800899

Chudy A., 2019. The review of selected electrical energy storage techniques. IAPGOŚ 9(1), 2328. https://doi.org/10.5604/01.3001.0013.0890

DeRousseau M., Gully B., Taylor C., Apelian D., Wang Y., 2017. Repurposing Used Electric Car Batteries: A Review of Options. JOM 69(9), 1575-1582. https://doi.org/10.1007/s11837-0172368-9

Faria R., Marques P., Garcia R., Moura P., Freire F., Delgado J., Almeida A.T. de, 2014. Primary and secondary use of electric mobility batteries from a life cycle perspective. J. Power Sources 262, 169-177. https://doi.org/10.1016/j.jpowsour.2014.03.092

Hannan M.A., Hoque M.M., Hussain A., Yusof Y., Ker P.J., 2018. State-of-the-Art and Energy Management System of Lithium-Ion Batteries in Electric Vehicle Applications: Issues and Recommendations. IEEE Access $\quad 6, \quad 19362-19378$. https://doi.org/10.1109/ACCESS.2018.2817655

Hawkins T.R., Gausen O.M., Strømman A.H., 2012. Environmental impacts of hybrid and electric vehicles - a review. Int. J. Life Cycle Assess. 17(8), 997-1014. https://doi.org/10.1007/s11367-012-0440-9

Heelan J., Gratz E., Zheng Z., Wang Q., Chen M., Apelian D., Wang Y., 2016. Current and Prospective Li-Ion Battery Recycling and Recovery Processes. JOM 68(10), 2632-2638. https://doi.org/10.1007/s11837-016-1994-y

Horiba T., 2014. Lithium-Ion Battery Systems. Proc. IEEE 102(6), 939-950. https://doi.org/10.1109/JPROC.2014.2319832

Kwade A., Haselrieder W., Leithoff R., Modlinger A., Dietrich F., Droeder K., 2018. Current status and challenges for automotive battery production technologies. Nat. Energy 3(4), 290 300. https://doi.org/10.1038/s41560-018-0130-3

Li W., Zhu J., Xia Y., Gorji M.B., Wierzbicki T., 2019. Data-Driven Safety Envelope of LithiumIon Batteries for Electric Vehicles. Joule 3(11), 2703-2715. https://doi.org/10.1016/j.joule.2019.07.026 
Meister P., Jia H., Li J., Kloepsch R., Winter M., Placke T., 2016. Best Practice: Performance and Cost Evaluation of Lithium Ion Battery Active Materials with Special Emphasis on Energy Efficiency. Chem. Mater. 28(20), 7203-7217. https://doi.org/10.1021/acs.chemmater.6b02895

Miao Y., Hynan P., Jouanne A. von, Yokochi A., 2019. Current Li-Ion Battery Technologies in Electric Vehicles and Opportunities for Advancements. Energies 12(6), 1074. https://doi.org/10.3390/en12061074

Olsson L., Fallahi S., Schnurr M., Diener D., Loon P. van, 2018. Circular Business Models for Extended EV Battery Life. Batteries 4(4), 57. https://doi.org/10.3390/batteries4040057

Schuster S.F., Bach T., Fleder E., Müller J., Brand M., Sextl G., Jossen A., 2015. Nonlinear aging characteristics of lithium-ion cells under different operational conditions. J. Energy Storage 1, 44-53. https://doi.org/10.1016/j.est.2015.05.003

Tong D., Zhang Q., Zheng Y., Caldeira K., Shearer C., Hong C., Qin Y., Davis S.J., 2019. Committed emissions from existing energy infrastructure jeopardize $1.5^{\circ} \mathrm{C}$ climate target. Nature 572(7769), 373-377. https://doi.org/10.1038/s41586-019-1364-3

Winslow K.M., Laux S.J., Townsend T.G., 2018. A review on the growing concern and potential management strategies of waste lithium-ion batteries. Resour. Conserv. Recycl. 129, 263277. https://doi.org/10.1016/j.resconrec.2017.11.001

Winter M., Barnett B., Xu K., 2018. Before Li Ion Batteries. Chem. Rev. 118(23), 11433-11456. https://doi.org/10.1021/acs.chemrev.8b00422

Zeng X., Li J., Singh N., 2014. Recycling of Spent Lithium-Ion Battery: A Critical Review. Crit. Rev. Environ. Sci. Technol. 44(10), 1129-1165. https://doi.org/10.1080/10643389.2013.763578 
Magdalena Cieplak $\mathbb{B}^{1}$, Sylwia Okoń $\mathbb{D}^{2}$

\title{
Efektywność genów owsa warunkujących jego odporność na mączniaka prawdziwego i rdzę koronową na terenie Polski
}

\author{
Efficiency of genes conditioning resistance to powdery mildew \\ and crown rust in oats in Poland
}

\begin{abstract}
Wstęp
Owies zwyczajny (Avena sativa L.) jest jednym z sześciu najchętniej uprawianych gatunków zbóż na całym świecie. Jest to zboże wrażliwe na wiele chorób, które mogą w istotny sposób obniżać wielkość i jakość plonów. Głównymi chorobami grzybowymi porażającymi uprawy owsa są rdza koronowa, mączniak prawdziwy oraz fuzariozy powodowane przez różne gatunki z rodzaju Fusarium. W przypadku mączniaka czynnikiem infekcyjnym jest biotroficzny grzyb Blumeria graminis f. sp. avenae należący do Erysiphales [Takamatsu 2004, Dean $i$ in. 2012]. Choroba ta zmniejsza plon ziarna o $10-40 \%$, odpowiednio w latach niskiego i wysokiego nasilenia [Lawes i Hayes 1965, Jones i in. 1987]. Kolejną groźną chorobą roślin owsa jest rdza koronowa. Występuje ona nie tylko w warunkach naszego kraju, ale również $\mathrm{w}$ centralnej i południowowschodniej Europie, w basenie Morza Śródziemnego, Ameryce Płn. i Płd. oraz Australii. Jest ona wywołana przez obligatoryjny, biotroficzny grzyb Puccinia coronata Cda. f. sp. avenae P. Syd. \& Syd. [Simons 1985, Sebesta i in. 2003, Nazareno i in. 2018]. Rdza koronowa wywołuje straty plonu, które mogą osiągnąć wartość 50\% [Martinelli i in. 1994].

Istnieje wiele metod zapobiegających występowaniu chorób grzybowych, lecz żadna $\mathrm{z}$ nich nie jest $\mathrm{w}$ stanie zapewnić całkowitej kontroli. Wśród tych metod można wyróżnić: odpowiednie zabiegi agrotechniczne (płodozmian, optymalny termin siewu, przedplony), metody chemiczne (fungicydy) oraz wprowadzanie odporności genetycznej [Sánchez-Martíni in. 2011]. Kontrola chemiczna wiąże się z wystąpieniem problemów wynikających z efektu resztkowego oraz toksyczności związków chemicznych. Z kolei kontrola genetyczna, m.in uprawa odpornych odmian, jest bardziej ekonomiczną i przyjazną środowisku

\footnotetext{
${ }^{1}$ Uniwersytet Przyrodniczy w Lublinie, Wydział Agrobioinżynierii, Instytut Genetyki, Hodowli i Biotechnologii Roślin, magdalena.cieplak@up.lublin.pl

${ }^{2}$ Uniwersytet Przyrodniczy w Lublinie, Wydział Agrobioinżynierii, Instytut Genetyki, Hodowli i Biotechnologii Roślin, sylwia.okon@up.lublin.pl
} 
metodą, ponieważ eliminuje potrzebę stosowania środków grzybobójczych i zmniejsza koszty produkcji. Ponadto rolnicy w krajach rozwijających się preferują uprawę odmian odpornych ze względu na możliwość wytworzenia odporności patogenu na dany fungicyd [Goutam i in. 2015, Aktar-Uz-Zaman i in. 2017]. Specyficzna rasowo odporność genetyczna warunkowana monogenicznie jest powszechnie stosowana $\mathrm{u}$ owsa $\mathrm{w}$ walce $\mathrm{z}$ patogenami, m.in. $\mathrm{z}$ mączniakiem prawdziwym oraz rdzą koronową. Otrzymywanie odmian odpornych wiąże się z ciągłym poszukiwaniem nowych źródeł odporności oraz monitorowaniem ich efektywności, gdyż szybka ewolucja patogenu powoduje powstawanie nowych ras przełamujących odporność warunkowaną przez dotychczas efektywne geny [Nazareno i in. 2018]. Ciągłe pojawianie się nowych form patogenów przełamujących odporność efektywnych dotychczas genów jest poważnym problemem nowoczesnej hodowli roślin, dlatego obiecującą metodą zwiększenia trwałości odporności jest prowadzenie hodowli opartej na kumulowaniu najbardziej skutecznych genów.

Dotychczas u owsa zidentyfikowano i scharakteryzowano 11 genów odporności na mączniaka prawdziwego [Hsami in. 2014, Herrmann i Mohler 2018, Ociepa $i$ in. 2020]. Dane dostępne w literaturze pokazują, że powszechnie wykorzystywane w komercyjnych odmianach z Europy i Ameryki Północnej były geny Pm1, Pm3 i Pm6 [Hsam i in. 1997, 1998, Okoń 2012, Okoń i in. 2016]. Herrmann i Mohler [2018] zwracają uwagę na coraz powszechniejsze zastosowanie genu $P m 7$ w celu podnoszenia odporności niemieckich odmian. Brak jest natomiast doniesień dotyczących wprowadzania genów Pm2, Pm4 i Pm5 do form uprawnych owsa. W przypadku rdzy koronowej opisano dotychczas ponad 100 genów odporności na różne rasy fizjologiczne Puccinia coronata f. sp. avenae. Geny te zidentyfikowano zarówno wśród odmian A. sativa, jak i dzikich gatunków A. sterilis, A. barbata, A. maroccana, A. murphyi i A. strigosa [Aung i in. 1977, Rines i in. 2018, Carson 2009]. Oceny efektywności genów warunkujących odporność przeważnie określa się na podstawie testów żywiciel - patogen, które opierają się na obserwacji wpływu zakażenia grzybem na badaną formę o nieznanej odporności i porównaniu tej reakcji z reakcją linii o znanych genach odporności [Hsam i in. 1997, 1998, Yu i Herrmann 2006, Okoń i Kowalczyk 2012, Sowa i in. 2016, Okoń i in. 2018].

Celem niniejszej pracy było usystematyzowanie wiadomości oraz przegląd badań dotyczących efektywności opisanych do tej pory genów warunkujących odporność owsa na mączniaka i rdzę koronową na terenie Polski.

\section{Opis zagadnienia}

Pierwsze szczegółowe badania nad efektywnością genów warunkujących odporność na Puccinia coronata w warunkach europejskich zostały przeprowadzone w latach 1992-1993 [Sebesta i in. 2003]. Kolejne dotyczyły populacji 
P. coronata w Republice Czeskiej w latach 2004-2006 [Jiráková i Hanzalová 2008]. W pracy Róg in. [2015] określano efektywność genów wobec izolatów $P$. coronata wyprowadzonych z populacji zebranych w centralnej i południowo-wschodniej Polsce w latach 2010-2011. W testach fitopatologicznych wykorzystano 31 linii referencyjnych owsa z pojedynczymi genami odporności na rdzę koronową oraz 6 izolatów $P$. coronata. Analiza wykazała, że najbardziej efektywne w stadium siewki były geny Pc14, Pc39, Pc51, Pc52, Pc53, Pc57, Pc60, $P c 68, P c 71$ i $P c 91$. Kontynuacją badań były obserwacje Sowy i Paczos-Grzędy [2017] dotyczące widma wirulencji 12 populacji $P$. coronata skolekcjonowanych w centralnej i południowo-wschodniej Polsce, w dziewięciu lokalizacjach, w stosunku do 27 linii referencyjnych z różnymi genami odporności. Testy żywiciel - patogen wykazały, że populacje $P$. coronata pochodzące $\mathrm{z}$ różnych regionów uprawy owsa charakteryzowały się wirulencją względem 2-15 genów $P c$. Żadna $\mathrm{z}$ analizownych populacji $P$. coronata nie przełamała odporności warunkowanej genami: Pc50, Pc52, Pc59, Pc60, Pc71, Pc91 oraz Pc94. Zaobserwowano sporadyczną wirulencję w stosunku do genów $P c 48, P c 68$ i $P c 70$. Badania potwierdziły, że wiele znanych źródeł odporności na patogen $P$. coronata są nadal skuteczne. Kompleksowe badania efektywności genów względem izolatów $P$. coronata wyprowadzonych z populacji zebranych w latach 2013-2015 na terenie całej Polski zawarto w pracy Paczos-Grzędy i Sowy [2019]. Przedmiotem doświadczenia były 162 izolaty z trzech lokalizacji rozmieszczonych na terenie całego kraju. Dokonano oceny wirulencji poszczególnych izolatów względem 26 linii referencyjnych z genami $P c$. Średnio pojedynczy izolat przełamywał odporność warunkowaną przez 5-7 genów. Średni poziom wirulencji w każdym roku badań był bardzo zbliżony i wynosił ok. $21 \%$, wahając się od 8 do $54 \%$, od 4 do $62 \%$ oraz od 4 do $54 \%$ - w kolejnych latach. Żaden $\mathrm{z}$ analizowanych dotychczas izolatów nie przełamywał odporności linii z genem $P c 91$, a tylko pojedyncze były wirulentne w stosunku do genów $P c 71$ i $P c 52$. Odporność warunkowały również geny $P c 50, P c 51, P c 59, P c 60$ i $P c 70$. Wysoką efektywność wyżej wymienionych genów zaobserwowano również w innych badaniach [Róg i in. 2015, Sowa i Paczos-Grzęda 2017].

Pierwsze doniesienia dotyczące odporności linii ze zidentyfikowanymi genami odporności na mączniaka prawdziwego owsa pochodzą z lat 1977-1998 [Aung i in. 1977, Roderick i Jones 1988, Sebesta i in. 1991, Roderick i in. 2000]. W publikacji Herrmann i Roderick [1996] opisano linię APR122 jako wysoce odporną zarówno w warunkach laboratoryjnych, w stadium siewki, jak i w stadium rośliny dorosłej. Również Hsam i in. [1997, 1998] wykazali, że linia APR122 z genem $\operatorname{Pm} 7$ charakteryzuje się wysokim poziomem odporności wobec zastosowanych izolatów mączniaka prawdziwego. Hsam i in. [1997, 1998] zaobserwowali także, że gen $P m 4$ był wysoce efektywny przeciwko mączniakowi prawdziwemu w owsie. Brak jest natomiast jakichkolwiek informacji na temat efektywności genów Pm1, Pm3 i Pm6, które zostały zidentyfikowane w wielu odmianach owsa [Hsam i in. 1997, 1998, Okoń i in. 2016]. W pracy 
Okoń i in. [2016] badano efektywność opisanych do tej pory genów odporności na mączniaka prawdziwego w warunkach Polski. Przedmiotem analiz były linie i odmiany referencyjne: 'Jumbo' z genem Pml, 'Mostyn' z genem Pm3, Av1860 z genem Pm4, 'Bruno' z genem Pm6, APR122 z genem Pm7. Ocenę efektywności genów przeprowadzono $\mathrm{z}$ wykorzystaniem jednozarodnikowych izolatów mączniaka prawdziwego skolekcjonowanych na terenie kraju. Przeprowadzone analizy wykazały, że geny $P m l$ i $P m 3$ są nieefektywne wobec populacji mączniaka prawdziwego występującego obecnie na terenie Polski Wschodniej. Wobec izolatów patogenu zebranych w Polsce Zachodniej wykazały umiarkowany poziom efektywności. Również gen $P m 6$ nie warunkował wysokiego poziomu odporności linii referencyjnej. Odporność warunkowana tym genem została przełamana przez wszystkie izolaty zebrane na terenie kraju. Przeprowadzone badania wykazały, że najbardziej efektywne w warunkach Polski są geny Pm4 i $P m 7$. Gen $P m 4$ był całkowicie odporny na wszystkie izolaty mączniaka wykorzystane w testach żywiciel-patogen. Gen $P m 7$ wykazał odporność na 53 izolaty mączniaka prawdziwego. Wobec dwóch izolatów skolekcjonowanych w Polsce zachodniej wykazał odpowiedź umiarkowaną. Można więc przypuszczać, że odporność warunkowana genem $P m 7$ będzie słabła w kolejnych latach, w miarę pojawiania się nowych, bardziej wirulentnych populacji mączniaka prawdziwego.

W kolejnych badaniach Okoń i Ociepy [2017] analizowano poziom wirulencji populacji Blumeria graminis f. sp. avenae na terenie Polski. Przedmiotem badań były populacje $B g a$ zebrane z różnych części kraju w latach 2010-2013. Z każdej populacji patogenu określonej lokalizacji uzyskano po 20 jednozarodnikowych izolatów. Frekwencję zjadliwości izolatów określono na podstawie testów żywiciel - patogen przeprowadzonych na zestawie 8 linii referencyjnych ze zdefiniowanymi genami odporności: 'Jumbo' - Pm1, Cc3678 - Pm2, 'Mostyn' Pm3, Av1860 - Pm4, Am27 - Pm5, 'Bruno' - Pm6 i APR122 - Pm7 oraz odmiany wrażliwej 'Fuchs'. Badane izolaty mączniaka prawdziwego niemal całkowicie przełamały odporność warunkowaną genami Pml, Pm3 i Pm6. Częstotliwość wirulencji wobec tych genów wyniosła $80-100 \%$. Próbki izolatów przełamały odporność warunkowaną genem $\operatorname{Pm} 7$, jednakże frekwencja wirulencji wobec tego genu utrzymała się na bardzo niskim poziomie, nie przekraczając $10 \%$. Z tego wynika, że występujące patotypy Bga zaczynają przełamywać odporność warunkowaną tym genem. Żaden z izolatów mączniaka prawdziwego nie przełamał odporności warunkowanej genami Pm2, Pm4 i Pm5. W eksperymencie tym określono również kompleksowość izolatów. Analizowane próbki mączniaka prawdziwego najczęściej przełamywały odporność trzech spośród siedmiu genów odporności wykorzystanych w testach żywiciel - patogen, były to geny Pml, Pm3 i Pm6. Żaden z izolatów mączniaka prawdziwego nie był w stanie przełamać odporności jednocześnie 5, 6 lub 7 genów poddanych analizie. 


\section{Podsumowanie}

Badania nad efektywnością genów warunkujących odporność na rdzę koronową oraz mączniaka prawdziwego pozwoliły wskazać te, które mogą zapewnić trwałą w czasie i przestrzeni odporność. Najbardziej efektywnym genem $P c$ pozostaje gen $P c 91$ - jedyny, względem którego na terenie kraju nie zidentyfikowano, jak dotąd, wirulentnych izolatów. Do genów warunkujących stosunkowo stabilną odporność należą $P c 52$ i $P c 71$, a także Pc50,Pc51,Pc59, Pc60 i $P c 70$. W przypadku mączniaka prawdziwego odporność warunkowana genami Pm1, Pm3, Pm6 została przełamana przez istniejące patotypy Blumeria f. sp. avenae również efektywność genu $P m 7$ zaczyna słabnać [Okoń 2015, Okoń i Ociepa 2018]. Najwyższy poziom odporności zapewniają obecnie geny $P m 2$, Pm4 i Pm5. Prawdopodobnie wynika to z faktu, że geny te nie są szeroko rozpowszechnione w odmianach uprawnych [Hsam i in. 1997, 2004, Okoń 2012].

Niewielka liczba odmian posiadających geny odporności sugeruje, że konieczne jest wprowadzenie do programów hodowlanych większej liczby genów warunkujących efektywną odporność. Jednakże wprowadzenie genów $B g$ i $P c$ pojedynczo lub ich kombinacji w wielu odmianach wywarłoby silną presję selekcyjną na populację patogenu, co prowadziłoby do powstania dominujących ras i spowodowało gwałtowny wzrost wirulencji w stosunku do wykorzystywanych genów [Chong i in. 2008]. Ważną strategią w hodowli odpornościowej jest tworzenie piramid genowych opartych na efektywnych genach odporności. Ich tworzenie pozwala na uzyskanie odporności na wiele ras patogenu i umożliwia utrzymanie efektywnej ochrony roślin owsa przez długi okres.

\section{Bibliografia}

Aktar-Uz-Zaman M., Tuhina-Khatun M., Hanafi M.M., Sahebi M., 2017. Genetic analysis of rust resistance genes in global wheat cultivars: an overview. Biotechnol. Biotec. Eq. 31(3), 431-445. https://doi.org/10.1080/13102818.2017.1304180

Aung T., Thomas H., Jones I.T., 1977. The transfer of the gene for mildew resistance from Avena barbata $(4 \mathrm{x})$ into the cultivated oat $A$. sativa by an induced translocation. Euphytica 26, 623-632. https://doi.org/10.1007/BF00021687

Carson M.L., 2009. Crown rust development and selection for virulence in Puccinia coronata f. sp. avenae in an oat multiline cultivar. Plant Dis. 93(4), 347-353. https://doi.org/10.1094/PDIS-93-4-0347

Chong J., Gruenke J., Dueck R., Mayert W., Woods S., 2008. Virulence of oat crown rust [Puccinia coronata f. sp. avenae] in Canada during 2002-2006. Can. J. Plant. Pathol. 30(1), 115-123. https://doi.org/10.1080/07060660809507502

Dean R., Van Kan J.A.L., Pretorius Z.A., Hammond-Kosack K.E., Di Pietro A., Spanu P.D., Foster G.D., 2012. The Top 10 fungal pathogens in molecular plant pathology. Mol. Plant Pathol. 13(4), 414-430. https://doi.org/10.1111/j.1364-3703.2011.00783.x

Goutam U., Kukreja S., Yadav R., Salaria N., Thakur K., Goyal A.K., 2015. Recent trends and perspectives of molecular markers against fungal diseases in wheat. Front. Microbiol. 6, 1-14. https://doi.org/10.3389/fmicb.2015.00861 
Herrmann M.H., Mohler V., 2018. Locating two novel genes for resistance to powdery mildew from Avena byzantina in the oat genome. Plant Breed. 137(6), 832-838. https://doi.org/doi:10.1111/pbr.12655

Herrmann M., Roderick H.W., 1996. Characterisation of new oat germplasm for resistance to powdery mildew. Euphytica 89(3), 405-410. https://doi.org/10.1007/BF00022300

Hsam S.L.K., Mohler V., Zeller F.J., 2014. The genetics of resistance to powdery mildew in cultivated oats (Avena sativa L.): Current status of major genes. J. Appl. Genet. 55(2), 155-162. https://doi.org/10.1007/s13353-014-0196-y

Hsam S.L.K., Paderina E.V., Gordei, S., Zeller F.J., 1998. Genetic studies of powdery mildew resistance in cultivated oat (Avena sativa L.). II. Cultivars and breeding lines grown in Northern and Eastern Europe. Hereditas 129(3), 227-230. https://doi.org/10.1111/j.16015223.1998.00227.x

Hsam S.L.K., Peters N., Paderina E.V., Felsenstein F., Oppitz K., Zeller F.J., 1997. Genetic studies of powdery mildew resistance in common oat (Avena sativa L.) I. Cultivars and breeding lines grown in Western Europe and North America. Euphytica 96(3), 421-427. https://doi.org/10.1023/A:1003057505151

Hsam S., Paderina E., Gordei S., Zeller F., 2004. Genetic Studies of Powdery Mildew Resistance in Cultivated Oat (Avena sativa L.) II. Cultivars and Breeding Lines Grown in Northern and Europe. Hereditas 129, 227-230. https://doi.org/10.1111/j.1601-5223.1998.00227.x

Jiráková H., Hanzalová A., 2008. Crown rust pathotypes determined on oats in the Czech Republic from 2004 to 2006 and reaction to oat cultivars. Czech J. Genet. Plant Breed., 44, 60-65. https://doi.org/10.17221/15/2008-CJGPB

Jones I.T., Roderick H.W., Clifford B.C., 1987. The integration of host resistance with fungicides in the control of oat powdery mildew. Ann. Appl. Biol. 110(3), 591-602. https://doi.org/10.1111/j.1744-7348.1987.tb04178.x

Lawes D.A., Hayes J.D., 1965. The effect of powdery mildew (Erysiphe graminis f.sp. avenae) on spring oats. Plant Pathol. 14(3), 125-128. https://doi.org/10.1111/j.1365-3059.1965.tb00295.x

Martinelli J.A., Federizzi L.C., Bennedetti A.C., 1994. Yield reductions of oat grains due to leaf rust severity. Summa Phytopathol. 20(2), 116-118.

Nazareno E.S., Li F., Smith M., Park R.F., Kianian S.F., Figueroa M., 2018. Puccinia coronata f. sp. avenae: a threat to global oat production. Mol. Plant Pathol. 19(5), 1047-1060. https://doi.org/10.1111/mpp.12608

Ociepa T., Okoń S., Nucia A., Leśniowska-Nowak J., Paczos-Grzęda E., Bisaga M., 2020. Molecular identification and chromosomal localization of new powdery mildew resistance gene Pm11 in oat. Theor. Appl. Gen. 133(1), 179-185. https://doi.org/10.1007/s00122-019-03449-3

Okoń S., 2012. Identification of powdery mildew resistance genes in Polish common oat (Avena sativa L.) cultivars using host-pathogen tests. Acta Agrobot. 65(3), 63-68. https://doi.org/10.5586/aa.2012.008

Okoń S., Kowalczyk K., 2012. Deriving isolates of powdery mildew (Blumeria graminis DC. f.sp. avenae Em. Marchal.) in common oat (Avena sativa L.) and using them to identify selected resistance genes. Acta Agrobot. 65(2), 155-160. https://doi.org/10.5586/aa.2012.069

Okoń S., Ociepa T., Nucia A., 2018. Molecular identification of Pm4 powdery mildew resistant gene in oat. Not. Bot. Horti Agrobot. Cluj-Napoca 46(2), 350-355. https://doi.org/10.15835/nbha46210904

Okoń S., Paczos-Grzęda E., Ociepa T., Koroluk A., Sowa S., Kowalczyk K., Chrząstek M., 2016. Avena sterilis L. Genotypes as a potential source of resistance to oat powdery mildew. Plant Dis. 100(10), 2145-2151. https://doi.org/10.1094/PDIS-11-15-1365-RE

Okoń S.M., 2015. Effectiveness of resistance genes to powdery mildew in oat. Crop Prot. 74, 48-50. https://doi.org/10.1016/j.cropro.2015.04.004

Okoń S.M., Ociepa T., 2017. Virulence structure of the Blumeria graminis DC. f. sp. avenae populations occurring in Poland across 2010-2013. Eur. J. Plant Pathol. 149(3), 711-718. https://doi.org/10.1007/s10658-017-1220-y 
Okoń S., Ociepa T., 2018. Effectiveness of new sources of resistance against oat powdery mildew identified in A. sterilis. J. Plant Diseases Prot. 125(5), 505-510. https://doi.org/10.1007/s41348018-0171-7

Paczos-Grzęda E., Sowa S., 2019. Virulence structure and diversity of Puccinia coronata f. sp. avenae P. Syd. \& Syd. in Poland during 2013-2015. Plant Dis. 103. https://doi.org/10.1094/PDIS-10-181820-RE

Rines H.W., Miller M.E., Carson M., Chao S., Tiede T., Wiersma J., Kianian S.F., 2018. Identification, introgression, and molecular marker genetic analysis and selection of a highly effective novel oat crown rust resistance from diploid oat, Avena strigosa. Theor. Appl. Genet. 131(0123456789), 721-733.

Roderick H.W., Jones E.R.L., Sebesta J., 2000. Resistance to oat powdery mildew in Britain and Europe: a review. Ann. Appl. Biol. 136(1), 85-91.

Roderick H.W., Jones I.T., 1988. The effect of powdery mildew (Erysiphe graminis f.sp. avenae) on yield, yield components and grain quality of spring oats. Ann. Appl. Biol., 113(3), 455-460. https://doi.org/10.1111/j.1744-7348.1988.tb03323.x

Róg S., Paczos-Grzęda E., Koroluk A., Okoń S., Ostrowska A., Erdzik P., Chrząstek M., Gruszecka D. , Kowalczyk K., 2015. Efektywność genów odporności na rdzę koronową u owsa zwyczajnego w stosunku do patotypów Puccinia coronata występujących w centralnej i południowo-wschodniej Polsce w latach 2010-2011. Ann. UMCS, sec. E, Agricultura 70(2), 97-105.

Sánchez-Martín J., Rubiales D., Prats E., 2011. Resistance to powdery mildew (Blumeria graminis f. sp. avenae) in oat seedlings and adult plants. Plant Pathol. 60(5), 846-856. https://doi.org/10.1111/j.1365-3059.2011.02453.x

Sebesta J., Kummer M., Roderick H.W., Hoppe H.D., Swierczewski A., Mueller K., 1991. Breeding of oats for resistance to rusts and powdery mildew in Central Europe. Ochrana Rostlin - UVTIZ (CSFR) 27(3-4), 229-238.

Sebesta J.B., Zwatz B., Roderick H., Corazza L., Manisterski J., Stojanovic S., 2003. Incidence of crown rust and virulence of Puccinia coronata Cda. f. sp. avenae Eriks. and the effectiveness of $P c$ genes for resistance in Europe, Middle East and North Africa. Arch. Phytopathol. Plant Prot. 36, 179-194. https://doi.org/10.1080/03235400310001604071

Simons M.D., 1985. Crown Rust. W: A.P. Roelfs, W.R. Bushnell (red.), Diseases, Distribution, Epidemiology, and Control, Vol. 2, The Cereal Rusts. Academic Press, Orlando, FL, 131-172. https://doi.org/https://doi.org/10.1016/B978-0-12-148402-6.50013-4

Sowa S., Paczos-Grzęda E., 2017. Puccinia coronata f.sp. avenae virulence in central and south-eastern Poland in 2014. Folia Pomer. Univ. Technol. Stetin., Agric., Aliment., Pisc., Zootech. 336(43)3, 157-166. https://doi.org/10.21005/AAPZ2017.43.3.17

Sowa S., Paczos-Grzęda E., Koroluk A., Okón S., Ostrowska A., Ociepa T., Kowalczyk K., 2016. Resistance to Puccinia coronata f. sp. avenae in Avena magna, A. murphyi, and A. insularis. Plant Dis. 100(6), 1184-1191. https://doi.org/10.1094/PDIS-06-15-0671-RE

Takamatsu S., 2004. Phylogeny and evolution of the powdery mildew fungi (Erysiphales, Ascomycota) inferred from nuclear ribosomal DNA sequences. Mycoscience 45(2), 147-157. https://doi.org/10.1007/S10267-003-0159-3

Yu J., Herrmann M., 2006. Inheritance and mapping of a powdery mildew resistance gene introgressed from Avena macrostachya in cultivated oat. Theor. Appl. Genet. https://doi.org/10.1007/s00122-006-0308-0 


\title{
Joanna Gmitrowicz-Iwan $\mathbb{D}^{1}$, Natalia Korcz $\mathbb{D}^{2}$, Magdalena Myszura $\mathbb{D}^{2}$, Joanna Trzcińska $\mathbb{D}^{2}$, Anna Orłowska ${ }^{2}$
}

\section{Nowoczesne techniki w geodezji leśnej}

Modern techniques in forest geodesy

\begin{abstract}
Wstęp
Geodezja tak jak każda inna dziedzina nauki zmienia się wraz z rozwojem technologii. Pomiary geodezyjne zmieniły swój charakter $z$ chwila wprowadzenia odbiorników GPS, tachimetrów elektronicznych oraz komputerów. Dane wysokiej jakości są otrzymywane w krótkim czasie. Ponadto rośnie znaczenie zobrazowań lotniczych i satelitarnych, które przesuwają granice geodezji - pomiary nie są lokalne, lecz globalne. Wiąże się to z rozwojem systemów informacji geograficznej (GIS), które służą do wprowadzania, gromadzenia, przetwarzania oraz wizualizacji danych geograficznych [Kwiecień 2009]. Wprowadzenie systemów komputerowych do przetwarzania danych to początek GIS. W latach $50 . \mathrm{XX}$ w. powstały pierwsze mapy opracowane komputerowo, w latach 60 . kartografia komputerowa została połączona z monitoringiem naziemnym i satelitarnym. Skutkiem tego w latach 70. powstały pierwsze systemy informacji geograficznej GIS [Olenderek 2010]. Poszerzyły one możliwości analiz i opracowań przestrzennych, również w leśnictwie [Dong i in. 2010]. Wprowadzony w Polsce w 1995 r. System Informatyczny Lasów Państwowych (SILP) był początkiem budowy systemów informacji przestrzennej dla nadleśnictw, podstawą rozwoju badań naukowych oraz edukacji uniwersyteckiej i społecznej [Olenderek 2006].

Rozwój SILP nie byłby jednak możliwy gdyby nie rozwój najnowszych technik pomiarowych: fotogrametrii i teledetekcji. W krótkim czasie dostarczają one złożonych danych dotyczących rozległych terenów. Wykorzystując najnowsze technologie i odpowiednie oprogramowanie, można otrzymać informacje dotyczące składu gatunkowego lasu, zwarcia drzewostanu czy granicy występowania zjawisk, np. chorób drzew czy pożarów [Barrett i in. 2001, Dong i in. 2005]. Geodezja leśna jest więc obecnie połączeniem klasycznej geodezji, leśnictwa oraz informatyki.
\end{abstract}

\footnotetext{
${ }^{1}$ Uniwersytet Przyrodniczy w Lublinie, joanna.gmitrowicz@gmail.com

${ }^{2}$ Uniwersytet Przyrodniczy w Lublinie
} 


\section{Fotogrametria}

Fotogrametria to dział geomatyki, który zajmuje się zdalnym pozyskiwaniem informacji o otoczeniu. Jej celem jest odtwarzanie rozmiarów, kształtów i wzajemnego położenia obiektów w terenie na podstawie zdjęć fotogrametrycznych (naziemnych, lotniczych lub satelitarnych). W leśnictwie ten dział nauki znalazł zastosowanie stosunkowo wcześnie. W Niemczech już w 1887 r. wykonywano zdjęcia z balonów, które służyły do kartowania drzewostanów. Fotogrametria prawdziwy przełom przeżyła w latach 20 . XX w. Pozwolił na to rozwój lotnictwa. Fotogrametryczne zdjęcia lotnicze (rys. 1) stały się ważnym źródłem informacji o rozległych obszarach leśnych, zwłaszcza w USA, ówczesnym ZSRR, Kanadzie i krajach skandynawskich. Pracowano również nad zastosowaniami w taksacji i pozyskiwaniu informacji o podstawowych cechach drzewostanów, takich jak jego wielkość, struktura czy zmiany zapasu [Mozgawa i in. 2000].

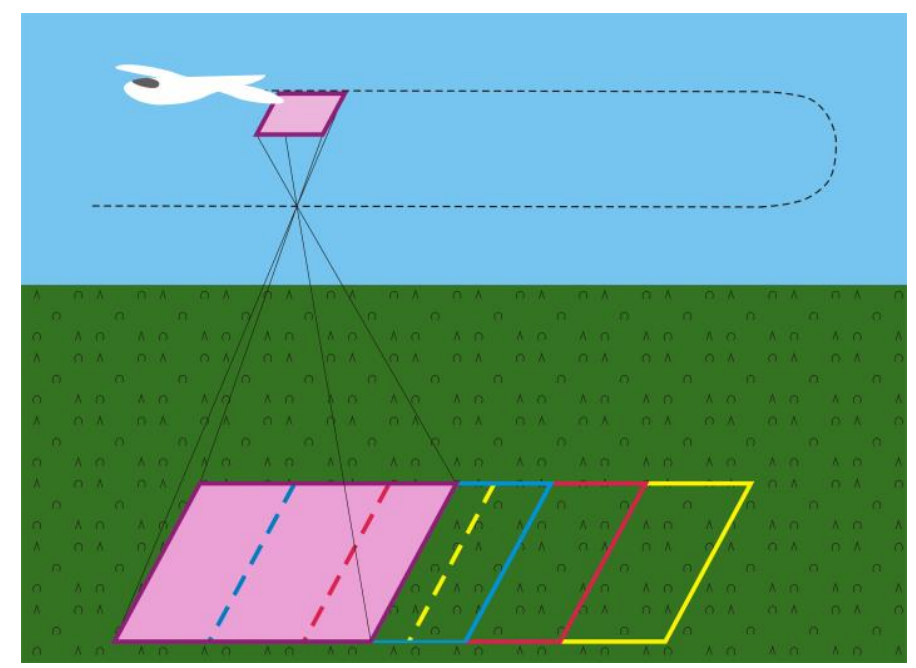

Rys. 1. Schemat nalotu fotogrametrycznego

Obecnie w leśnictwie wykorzystywane są zdjęcia fotogrametryczne wykonane specjalnie na potrzeby obrazowań leśnych. Od zwykłych zdjęć fotogrametrycznych odróżnia je uwzględnienie czynników przyrodniczych (charakterystyka spektralna roślinności leśnej: gatunek, wiek drzew, zwarcie okapu drzewostanu, stan zdrowotny drzew), pory sezonu wegetacyjnego, oświetlenia, stanu atmosfery oraz ukształtowania terenu. Warunki te wpływają na dobór parametrów technicznych, m.in. rodzaju kamery, filmu, skali, organizacji nalotu oraz technologii fotogrametrycznej [Będkowski 2010]. Odpowiednio wykonane zdjęcia znajdują zastosowanie w kartografii leśnej, taksacji, inwentaryzacji zapasu oraz ocenie stanu zdrowotnego i sanitarnego drzewostanów [Będkowski i in. 2006, Rahlf $i$ in. 2017]. 


\section{Teledetekcja}

Teledetekcja jest nauką techniczną zajmującą się zdalnym pozyskiwaniem, przetwarzaniem i interpretowaniem danych jakościowych o obiektach, zjawiskach i procesach na powierzchni Ziemi. Dziedzina ta jest nieco młodsza niż fotogrametria. Jej początki sięgają lat 60 . ubiegłego wieku, kiedy to pojęcie teledetekcji zaczęto stosować do obserwacji wykonanych na zdjęciach lotniczych. Obecnie pod pojęciem teledetekcji rozumiane jest zdalne pozyskiwanie i opracowywanie danych środowiskowych, $\mathrm{z}$ wykorzystaniem rejestracji promieniowania elektromagnetycznego. W zależności od rodzaju promieniowania teledetekcję dzieli się na pasywną i aktywną. Teledetekcja pasywna rejestruje promieniowanie odbite przez atmosferę oraz od obiektów znajdujących się na powierzchni Ziemi, jak również promieniowanie emitowane przez obiekty. Teledetekcja aktywna rejestruje promieniowanie generowane przez specjalne urządzenia lidarowe i radarowe. Wartości odbicia są mierzone i porównywane $\mathrm{z}$ wartościami promieni wysłanych. Pomiary teledetekcyjne dodatkowo dzielą się w zależności od sposobu zbierania informacji na naziemne, lotnicze i satelitarne. Różnią się przede wszystkim zasięgiem, teledetekcja naziemna stosowana jest do analiz lokalnych, zaś lotnicza i satelitarna dostarcza danych o rozległych obszarach [Zarzecki i Pasierbiński 2009, Zawiła-Niedźwiecki 2010].

\section{Pasywne techniki teledetekcyjne}

Pasywne techniki teledetekcyjne, tak jak już wspomniano, wykorzystują przede wszystkim odbite promieniowanie słoneczne oraz promieniowanie emitowane przez obiekty (głównie promieniowanie cieplne i mikrofalowe, rys. 2). W zależności od rodzaju i zakresu promieniowania teledetekcja pasywna może znaleźć różne zastosowania $\mathrm{w}$ analizach roślinności, w tym w analizach lasów.

$\mathrm{Na}$ czarno-białych zdjęciach panchromatycznych mogą być rejestrowane: zakres widzialny, bliski ultrafiolet i bliska podczerwień, przy czym dwa ostatnie zakresy są szczególnie przydatne w badaniach szaty roślinnej. Na zdjęciach panchromatycznych woda odwzorowywana jest w najciemniejszych tonach, jaśniejsze są lasy i roślinność trawiasta, najjaśniejsze są gleby piaszczyste. Na zdjęciach rejestrujących bliską podczerwień łatwo jest wyznaczyć wody (woda pochłania podczerwień) oraz rozróżnić skład gatunkowy lasu - drzewa liściaste są jaśniejsze ze względu na wysoką jasność spektralną. Różnice w wielkości odbicia wynikają z innych barwników w liściach, struktury komórkowej oraz zawartości wody i nutrientów w roślinie [Jarocińska i Zagajewski 2008].

Zdjęcia w barwach widzialnych rejestrują zakresy niebieski, zielony i czerwony. Odpowiednie zwizualizowanie kanałów skutkuje uzyskaniem obrazu o prawdziwych kolorach. Ten typ zobrazowań wykorzystywany jest głównie do prac topograficznych oraz aktualizacji mapy, jest jednak mało przydatny w analizach przyrodniczych [Będkowski 2010]. 


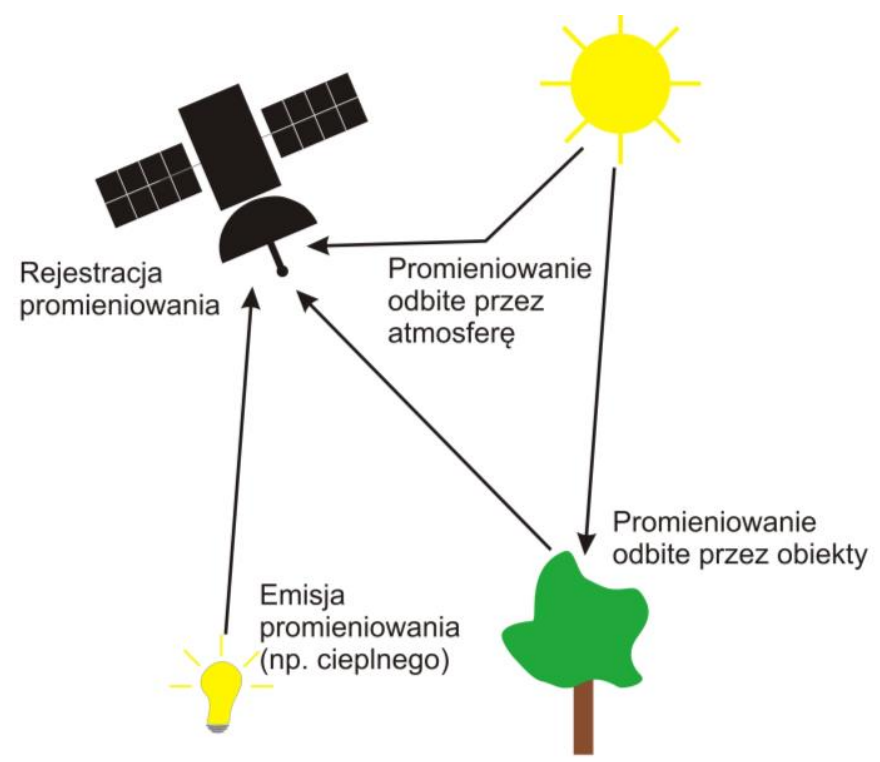

Rys. 2. Teledetekcja pasywna - schemat zasady działania

Na zdjęciach wykonanych w bliskiej podczerwieni można łatwo rozróżnić drzewostany iglaste od liściastych, strukturę wiekową, formy zmieszania lasu. Wadą tego typu zobrazowania jest wysoki stopień pochłaniania promieniowania podczerwonego przez atmosferę [Zajączkowski i Wężyk 2004]. W analizach przyrodniczych często wykorzystywane są zdjęcia w barwach umownych, które wykorzystują pasma zielone, czerwone i bliskiej podczerwieni. Podczas wizualizacji niewidocznej dla ludzkiego oka podczerwieni dochodzi do przesunięcia barw, wskutek czego roślinność na takich obrazach ma barwę czerwoną [Jarocińska i Zagajewski 2008].

W teledetekcji wykorzystywane jest również promieniowanie termalne (zakres podczerwieni). Pozwala ono na rejestrację temperatury z wysoką dokładnością. Służy m.in. do obliczania temperatury radiacyjnej powierzchni czynnej [Budzyńska $i$ in. 2011] oraz do liczenia zwierząt. W ostatnich latach zwłaszcza to drugie zastosowanie zyskuje na popularności. Zastosowanie termowizji $\mathrm{w}$ inwentaryzacji zwierzyny jest szybsze i dokładniejsze od dotychczasowych metod, nie wymaga również tak licznego personelu - naloty prowadzone są przez bezzałogowe samoloty lub drony [Pagacz i Witczuk 2016]. Spektrum podczerwieni termalnej wykorzystywane jest również do oceny zagrożeń pożarowych oraz wykrywania aktywnych pożarów w lasach. Monitoring pożarów w tej technice ma wiele zalet: informacja dostarczana jest szybko, a pomiar można wykonać z użyciem bezzałogowych samolotów, nie narażając personelu [Vidal $i$ in. 1994, Rauste $i$ in. 1997, Yuan i in. 2017].

Zdjęcia wielospektralne pozyskiwane są przez sfotografowanie jednego obszaru w wielu (od kilku do kilkuset) kanałach spektralnych. Umożliwia to two- 
rzenie opracowań przeznaczonych na konkretne cele oraz ułatwia interpretację zdjęć. Wykorzystując odpowiednie zakresy spektralne, można obliczać różnego rodzaju wskaźniki roślinności. Najpopularniejszym wskaźnikiem jest NDVI (Normalised Difference Vegetation Index, czyli wagowanie kanału bliskiej podczerwieni NIR i czerwieni R). NDVI uwydatnia obecność zielonej roślinności, nadając jej jasne tony [Ozdemir i Yilmaz 2020, Qiao i in. 2020]. Pozostałe wskaźniki to LAI (Leaf Area Index, czyli indeks powierzchni liścia), APAR (Absorbed Photosynthetically Active Radiation, czyli wskaźnik zaabsorbowanego promieniowania użytecznego dla fotosyntezy) oraz inne, dotyczące m.in. zawartości chlorofilu czy wielkości biomasy [Mularz i in. 2007, Hou i in. 2020, $\mathrm{Xu}$ i in. 2020]. Zobrazowania wielospektralne $\mathrm{i}$ obliczone na ich podstawie wskaźniki pozwalają na ocenę kondycji drzewostanów. Dzięki zastosowaniu odpowiednich algorytmów możliwe jest tworzenie map chorób drzew, ich wpływu na pozostałe elementy środowiska oraz powstawanie ryzyka pożarowego [Chen i in. 2017a, Mularz i in. 2007].

\section{Aktywne techniki teledetekcyjne}

Technika pomiarowa teledetekcji aktywnej polega na wysłaniu wiązki promieniowania, a następnie rejestracji fal odbitych (rys. 3), tzn. czasu, kąta i intensywności wiązki zwrotnej. Pozyskane dane służą do analizy środowiska, m.in. składu i budowy roślin: zawartości wody, celulozy, barwników fotosyntetycznie aktywnych, nutrientów, rodzaju struktur komórkowych [Jarocińska i Zagajewski 2008].

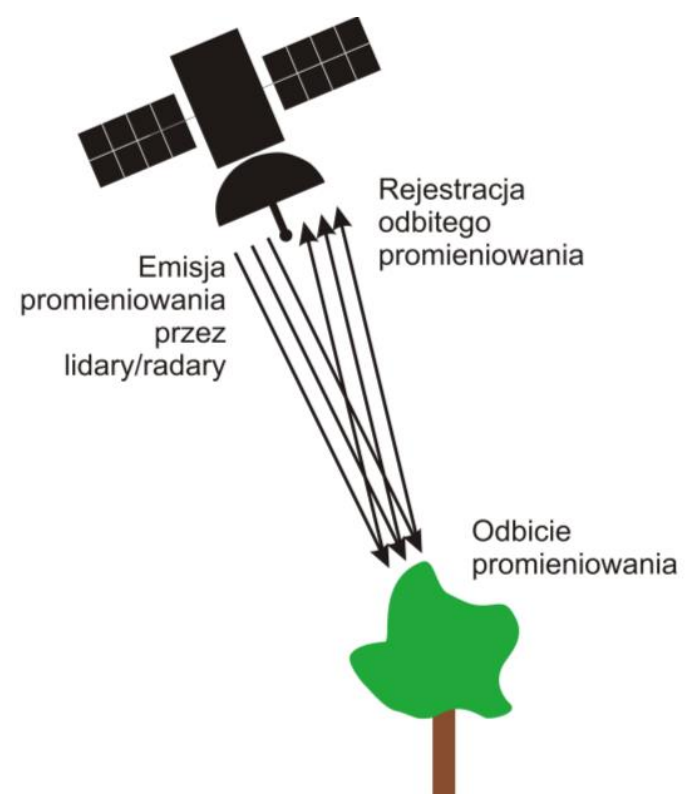

Rys. 3. Teledetekcja aktywna - schemat zasady działania 
Zdjęcia teledetekcyjne wykonywane są za pomocą dwóch zdalnych systemów aktywnego pozyskiwania informacji: RADAR i LIDAR. Obie te techniki wykorzystują promieniowanie wytworzone przez urządzenia, są więc niezależne od światła słonecznego, pomiary można wykonywać zarówno w dzień, jak i w nocy. Do pozyskiwania danych najczęściej wykorzystywane są satelity oraz bezzałogowe samoloty. Zwłaszcza te ostatnie mogą dostarczyć zdjęć o wysokiej rozdzielczości, ułatwiających analizy środowiska. RADAR, czyli Radio Detection And Ranging, wykorzystuje promieniowanie w zakresie mikrofalowym. Po odbiciu wiązki od obiektów rejestruje jej odbicie. Promieniowanie mikrofalowe przenika przez warstwy chmur, czyniąc tym samym pomiary radarowe niezależnymi od warunków pogodowych [Zawiła-Niedźwiecki 2010, Sankey i in. 2017]. W leśnictwie zdjęcia radarowe wykorzystywane są przede wszystkim do wyznaczania typów i wieku lasów, badania struktury lasu, obliczania ilości biomasy [Lu i in. 2016, Carreiras i in. 2017, Chen i in. 2017b].

W technice lidarowej (LIDAR, Light Detection And Ranging) wykorzystywana jest skoncentrowana wiązka promieniowania świetlnego (laserowego). Analiza powracającej wiązki pozwala na charakterystykę obiektów, od których została odbita, natomiast czas zarejestrowany między momentem wysłania wiązki a jej powrotem służy do określenia odległości między obiektem a źródłem promieniowania. Dane z lotniczych pomiarów lidarowych zwanych ALS (Airborne Laser Scanning), w postaci chmury punktów, wykorzystywane są do tworzenia numerycznego modelu terenu (NMT), co jest jednym z ich najpopularniejszych zastosowań. Ponadto tworzone są numeryczne modele pokrycia terenu (NMPT), numeryczne modele koron (CHM) oraz znormalizowane NMPT. Wykorzystanie modeli i odpowiednich algorytmów pozwala na określenie parametrów drzewostanów oraz podstawowych cech taksacyjnych, np. wysokości i liczby drzew, zwarcia koron, obecności luk i gniazd oraz pośrednio pierśnicy oraz zapasu drzewostanu [Będkowski i Wężyk 2010, Sadeghi i in. 2016]. Lotnicza technika lidarowa co raz powszechniej wykorzystywana jest do monitoringu lasów. Podobnie jak w przypadku pomiarów radarowych, pozwala na klasyfikację drzewostanu, ocenę jego struktury i składu gatunkowego. Ponadto pomiary lidarowe są podstawą do planowania odtworzeń drzewostanów [Sankey $\mathrm{i}$ in. 2017, Almeida i in. 2019].

\section{Podsumowanie}

Najnowsze techniki pomiarowe - fotogrametria i teledetekcja - znacznie rozwinęły geodezję. Skrócił się czas wykonywania pomiarów, a zwiększył się ich zasięg. Człowiek, wykorzystując samoloty i satelity jako platformy pomiarowe, jest w stanie zbadać tereny, które dotychczas były niedostępne lub zbyt rozległe, aby je zmierzyć. Geodezja leśna wykroczyła poza ramy klasycznej geodezji. Dzięki systemom pozycjonowania GNSS i teledetekcji możemy wy- 
konywać złożone analizy środowiskowe. Jest to szczególnie przydatne w leśnictwie. Dane teledetekcyjne dostarczają szerokiego zakresu informacji o lasach: od danych podstawowych, takich jak wiek i wysokość drzewostanu, skład gatunkowy, po mapy rozprzestrzeniania się chorób i pożarów czy inwentaryzację zwierzyny. Wyniki pomiarów zasilają SILP, tworząc podstawy do opracowywania m.in. planów urządzania lasu. Rozwój geodezji, a zwłaszcza fotogrametrii, teledetekcji i systemów GIS, znacząco wpłynął na poszerzenie wiedzy na temat lasów i ogólny rozwój leśnictwa.

\section{Bibliografia}

Almeida D.R.A., Stark S.C., Chazdon R., Nelson B.W., Cesar R.G., Meli P., Gorgens E.B., Duarte M.M., Valbuena R., Moreno V.S., Mendes A.F., Amazonas N., Gonçalves N.B., Silva C.A., Schietti J., Brancalion P.H.S., 2019. The effectiveness of lidar remote sensing for monitoring forest cover attributes and landscape restoration. For. Ecol. Manag. 438, 34-43. https://doi.org/10.1016/j.foreco.2019.02.002

Barrett M., Sahay S., Walsham G., 2001. Information technology and social transformation: GIS for forestry management in India. Inf. Soc. 17(1), 5-20. https://doi.org/10.1080/019722401750067397

Będkowski K., 2010. Specyfika fotogrametrii leśnej. W: K. Okła (red.), Geomatyka w lasach państwowych. Część I. Podstawy. CILP, Warszawa, 357-367.

Będkowski K., Adamczyk J., Mikrut S., 2006. Współczesne techniki fotogrametrii i ich zastosowanie w leśnictwie. PTPI, Rocz. Geom. 4(4), 55-65.

Będkowski K., Wężyk, P., 2010. Lotniczy skaning laserowy. W: K. Okła (red.), Geomatyka w lasach państwowych. Część I. Podstawy. CILP, Warszawa, 326-343.

Budzyńska M., Dąbrowska-Zielińska K., Turlej K., Małek I., Bartold M., 2011. Monitoring przyrodniczy Bagien Biebrzańskich z zastosowaniem teledetekcji. Woda Środ. Obsz. Wiej. 11(3), 39-64.

Carreiras J.M.B., Jones J., Lucas R.M., Shimabukuro Y.E., 2017. Mapping major land cover types and retrieving the age of secondary forests in the Brazilian Amazon by combining single-date optical and radar remote sensing data. Remote Sens. Environ. 194, 16-32. https://doi.org/10.1016/j.rse.2017.03.016

Chen G., He Y., De Santis A., Li G., Cobb R., Meentemeyer R.K., 2017a. Assessing the impact of emerging forest disease on wildfire using Landsat and KOMPSAT-2 data. Remote Sens. Environ. 195, 218-229. https://doi.org/10.1016/j.rse.2017.04.005

Chen Y., Hakala T., Karjalainen M., Feng Z., Tang J., Litkey P., Kukko A., Jaakkola A., Hyyppä J., 2017b. UAV-Borne Profiling Radar for Forest Research. Remote Sens. 9, 58. https://doi.org/10.3390/rs9010058

Dong C., Liu F., Wang H., Chen F., 2010. Application research of mobile GIS in forestry informatization. 5th International Conference on Computer Science \& Education, Hefei, 351-355.

Dong X., Li-min D., Guo-fan S., Lei T., Hui W., 2005. Forest fire risk zone mapping from satellite images and GIS for Baihe Forestry Bureau, Jilin, China. J. Forestry Res. 16, 169-174. https://doi.org/10.1007/BF02856809

Hou W., Su J., Xu W., Li X., 2020. Inversion of the Fraction of Absorbed Photosynthetically Active Radiation (FPAR) from FY-3C MERSI Data. Remote Sens. 12(1), 67. https://doi.org/10.3390/rs12010067

Jarocińska A., Zagajewski B., 2008. Korelacje naziemnych i lotniczych teledetekcyjnych wskaźników roślinności dla zlewni Bystrzanki. Teledet. Środ. 40, 100-124.

Kwiecień J., 2009. Technologia GIS w leśnictwie. W: K. Kannenberg, H. Szramka (red.), Zarządzanie ochroną przyrody w lasach. Wyd. Wyższej Szkoły Zarządzania Środowiskiem w Tucholi, 247-251. 
Lu D., Chen Q., Wang G., Liu L., Li G., Moran E., 2016. A survey of remote sensing-based aboveground biomass estimation methods in forest ecosystems. Int. J. Digit. Earth 9(1), 63-105. https://doi.org/10.1080/17538947.2014.990526

Mozgawa J., Piekarski E., Olenderek H., Będkowski K., 2000. Fotogrametria i teledetekcja w leśnictwie w Polsce. AFKIT 10, 55-1-55-9.

Mularz S., Drzewiecki W., Pirowski T., 2007. Teledetekcyjne metody rejestracji krajobrazu. PTPI Rocz. Geom. 5 (8), 67-80.

Olenderek H., 2006. Misja geomatyki w rozwoju leśnictwa. PTPI, Rocz. Geom. 4(4), 9-14.

Olenderek H., 2010. Historia geomatyki w leśnictwie. W: K. Okła (red.), Geomatyka w lasach państwowych. Część I. Podstawy. CILP, Warszawa, 19-28.

Ozdemir I., Yilmaz S., 2020. Modelling litter mass using satellite NDVI images and environmental variables in a brutian pine forest located in the southwest of Turkey. Carbon Manag. 11(3), https://doi.org/10.1080/17583004.2020.1735917

Pagacz S., Witczuk J., 2016. Wykorzystanie samolotów bezzałogowych i termowizji do nocnej inwentaryzacji kopytnych. Stud. Mat. CEPL 49A(4), 50-57.

Qiao K., Zhu W., Xie Z., 2020. Application conditions and impact factors for various vegetation indices in constructing the LAI seasonal trajectory over different vegetation types. Ecol. Indic. 112, 106-153. https://doi.org/10.1016/j.ecolind.2020.106153

Rahlf J., Breidenbach J., Solberg S., Næsset E., Astrup R., 2017. Digital aerial photogrammetry can efficiently support large-area forest inventories in Norway. Int. J. Forest Res. 90(5), 710-718. https://doi.org/10.1093/forestry/cpx027

Rauste Y., Herland E., Frelander H., Soini K., Kuoremaki T., Ruokari A., 1997. Satellite-based forest fire detection for fire control in boreal forests. Int. J. Remote Sens. 18(12), 2641-2656. https://doi.org/10.1080/014311697217512

Sadeghi Y., St-Onge B., Leblon B., Simard M., 2016. Canopy Height Model (CHM) derived from a TanDEM-X InSAR DSM and an airborne lidar DTM in Boreal Forest. IEEE J-STARS 9(1), 381-397. https://doi.org/10.1109/JSTARS.2015.2512230

Sankey T., Donager J., McVay J., Sankey J.B., 2017. UAV lidar and hyperspectral fusion for forest monitoring in the southwestern USA. Remote Sens. Environ. 195, 30-43. https://doi.org/10.1016/j.rse.2017.04.007

Vidal A., Pinglo F., Durand H., Devaux-Ros C., Maillet A., 1994. Evaluation of a temporal fire risk index in mediterranean forests from NOAA thermal IR. Remote Sens. Environ. 49(3), 296-303. https://doi.org/0.1016/0034-4257(94)90024-8

Xu B., Li J., Park T., Liu Q., Zeng Y., Yin G., Yan K., Chen C., Zhao J., Fan W., Knyazikhin Y., Myneni R.B., 2020. Improving leaf area index retrieval over heterogeneous surface mixed with water. Remote Sens. Environ. 240, 111700. https://doi.org/10.1016/j.rse.2020.111700

Yuan C., Liu Z., Zhang Y., 2017. Aerial images-based forest fire detection for firefighting using optical remote sensing techniques and unmanned aerial vehicles. J. Intell. Robot. Syst. 88, 635-654. https://doi.org/10.1007/s10846-016-0464-7

Zajączkowski G., Wężyk P., 2004. Techniki teledetekcyjne w inwentaryzacji urządzeniowej lasu. PTPI, Rocz. Geom. 2(4), 41-56.

Zarzecki M., Pasierbiński A., 2009. Zastosowanie GIS i teledetekcji w badaniach szaty roślinnej. Wiad. Bot. 53 (3/4), 53-66.

Zawiła-Niedźwiecki T., 2010. Teledetekcja i fotogrametria obszarów leśnych. W: K. Okła (red.), Geomatyka w lasach państwowych. Część I. Podstawy. CILP, Warszawa, 277-297. 
Mikołaj Kostryco@ ${ }^{1}$, Mirosława Chwil $\mathbb{1}^{2}$

\title{
Liposomy jako nośniki fitozwiązków
}

Liposomes as carriers of phytochemicals

\begin{abstract}
Wstęp
Nanotechnologia jest interdyscyplinarną dziedziną nauki, w której do tworzenia nanostruktur wykorzystywane są m.in. fitozwiązki rozpatrywane w nanoskali [Schiemann 2005]. Metody stosowane w nanotechnologii pozwoliły na modyfikację farmaceutyków i produktów kosmetycznych [Gazit 2007]. W procesie tym istotną rolę odgrywają nanocząsteczki zbudowane z kilkudziesięciu do kilku tysięcy atomów srebra i złota [Lopez-Sanchez i in. 2011]. Ze względu na małą wielkość struktury wnikają do żywych komórek, m.in. wprowadzając związki biologicznie czynne o działaniu przeciwzapalnym, przeciwnowotworowym lub przenosząc przeciwciała [Mitura 2006, Akbarzadeh i in. 2012].

$\mathrm{W}$ ostatnich latach wzrosło zainteresowanie nanocząsteczkami z powodu szerokiego zakresu ich zastosowania $\mathrm{w}$ różnych gałęziach przemysłu, np. kosmetologii, farmacji, medycynie, biotechnologii, elektronice, informatyce i optyce. Nanostruktury mają zastosowanie także w przemyśle odzieżowym, systemach oczyszczania wody i powietrza, w produkcji opakowań i paliw oraz w rolnictwie [Jung 2014, Orzechowska i Szymańska 2016]. Obecnie nanomateriały, m.in. liposomy, wykorzystywane są jako nośniki substancji biologicznie czynnych w wielu produktach farmaceutycznych i kosmetycznych.

W niniejszej pracy określono właściwości, działanie i zastosowania liposomów jako nośników substancji biologicznie czynnych na podstawie przeglądu literatury dotyczącej osiągnięć nanotechnologii w tworzeniu nanostruktur.
\end{abstract}

\section{Struktura liposomu}

Nazwa liposom pochodzi z greckich słów lipos i soma, pierwszy wyraz oznacza tłuszcz, a drugi ciało, a określenie liposomy tłumaczy się jako ciałka lipidowe. Struktury te po raz pierwszy zostały opisane w 1961 r. [Swami i in.

\footnotetext{
${ }^{1}$ Uniwersytet Przyrodniczy w Lublinie, Wydział Biologii Środowiskowej, Katedra Botaniki

${ }^{2}$ Uniwersytet Przyrodniczy w Lublinie, Wydział Biologii Środowiskowej, Katedra Botaniki, miroslawa.chwil@up.lublin.pl
} 
2015]. Liposomy są to kuliste, wodno-lipidowe pęcherzyki zbudowane $\mathrm{z}$ fosfolipidów, złożone $\mathrm{z}$ jednej podwójnej lub kilku warstw lipidów o wymiarach od 0,01 do $1,0 \mu \mathrm{m}$. Stanowią mikrorezerwuar substancji biologiczne czynnej zamkniętej w swoim wnętrzu [Jankowski i in. 2011, Sarecka-Hujar i in. 2011]. Błony liposomów mają ok. 4 nm grubości [Souto i in. 2008, Laouini i in. 2012]. Fosfolipidy wchodzące w skład liposomów są związkami amfifilowymi, posiadają część hydrofobową (ogonek) i hydrofilową (główkę). Taka struktura warunkuje dużą szczelność liposomów, dlatego są doskonałymi nośnikami m.in. biozwiązków wykorzystywanych w rolnictwie, farmacji, medycynie, kosmetyce i produkcji żywności [Arakane i in. 1993]. W środowisku wodnym powstający liposom może inkorporować określoną objętość roztworu $\mathrm{z}$ rozpuszczonym związkiem aktywnym. Substancje biologicznie czynne (hydrofilowe) mogą być usytuowane we wnętrzu liposomów, zaś hydrofobowe w dwuwarstwie lipidowej [Łukasiewicz 2012].

W skład liposomów mogą wchodzić obojętne i anionowe lub obojętne i kationowe lipidy [Hafez i in. 2000, Li i Schick 2001]. Do otrzymywania liposomów wykorzystuje się m.in. lecytynę, sfingolipidy i niejonowe związki powierzchniowo czynne. W procesie tworzenia liposomów używa się naturalnej lecytyny otrzymywanej z żółtka jaja kurzego [Park i in. 2001]. Żółtko zawiera $30 \%$ sumy lipidów, wśród nich 70-80\% stanowi lecytyna (fosfatydylocholina) [Siepka i in. 2010, Kijowski i in. 2013]. Oprócz lecytyny ważnym składnikiem tych struktur jest cholina. Substancje te stanowią m.in. składnik błon komórkowych [Park i in. 2001, Kawai i in. 2011, Yu i in. 2012]. Wśród surowców roślinnych lecytynę zawierają nasiona m.in. soi, rzepaku i słonecznika [Wettstein i in. 2000].

Sfingolipidy - kolejny składnik liposomów - stanowią ważny lipidowy element strukturalny błon biologicznych [Murray i in. 2011]. Ważną rolą sfingolipidów jest przekaźnictwo sygnałów, m.in. aktywacja receptora jądrowego lub receptora związanego z białkiem. Wśród tych związków najpowszechniej występującym u eukariotów jest sfingomielina [Dąbrowska i in. 2015].

\section{Właściwości liposomów}

Liposomy są dobrze znanymi pęcherzykowymi systemami dostarczania substancji biologicznie czynnych odpowiedzialnych za utrzymanie odpowiedniego nawodnienia naskórka i wprowadzenie substancji, które samoistnie nie mogły pokonać bariery naskórka. Struktura liposomów jest podobna do błon biologicznych, umożliwia penetrację bariery naskórkowej. Liposomy okazały się bardzo użyteczne w terapii niektórych dermatoz, m.in. atopowych lub łuszczycy. Początkowo liposomy były stosowane w dziedzinie dermokosmetyki, obecnie ze względu na ich zdolność do transportowania substancji aktywnych do skóry i uwalniania ich w głębszych warstwach ze zwiększoną skutecznością wykorzystanie liposomów znacznie wzrosło [Rahimpour i Hamishehkar 2012]. 
Liposomy, z uwagi na systemy ochronne dla substancji biologicznie czynnych, są powszechnie stosowane $\mathrm{w}$ aplikacjach skórnych. Te nanostruktury wykorzystane w dermatologii i kosmetologii stanowią nośniki substancji biologicznie czynnych, np. fitozwiązków: antyutleniaczy, białek, witamin, koenzymu Q10, wielocukrów, kwasu hialuronowego [Goik i in. 2015]. Penetrację i przenikanie przez skórę kwasu hialuronowego 6,4 razy zwiększa kombinacja liposomów i ultradźwięków o niskiej częstotliwości [Kasetvatin i in. 2015]. Z kolei układ liposomowy w hydrożelu jest potencjalnym systemem do miejscowego dostarczania substancji aktywnych, m.in. przeciwutleniaczy, np. flawonoidów przechodzących przez barierę skóry [Kim i in. 2014]. Naturalne przeciwutleniacze wykazują właściwości przeciwzmarszczkowe, przeciwzapalne, przeciwnowotworowe i przeciwdrobnoustrojowe. Antyoksydanty w produktach kosmetycznych mogą być stosowane jako środki konserwujące lub składniki aktywne [Costa i Santos 2017]. Nowa generacja liposomów dostarcza przeciwutleniacze w kosmeceutykach. W grupie tych związków większość jest wrażliwa ze względu na niestabilność i nierozpuszczalność. Liposomy stanowią ochronę dla antyutleniaczy w określonych produktach farmaceutycznych i kosmetycznych [Van Tran $i$ in. 2019]. Liposomy zamykające koenzym Q10, silny przeciwutleniacz, przyśpieszają regenerację i spowalniają starzenie się skóry. Stosowane do jej pielęgnacji witaminy i inne biozwiązki mogą być skutecznie kapsułkowane w liposomach i aplikowane w odpowiednich produktach [Soni i in. 2016]. Liposomy zawierające retinoid lub analog tego związku, karotenoid albo tretynoinę, korzystnie wpływają na regenerację cery trądzikowej i nie podrażniają skóry, są stosowane jako kompozycje farmaceutyczne, zwłaszcza dermatologiczne lub kosmetyczne [Meybeck i in. 1991].

\section{Wykorzystanie liposomów}

Pierwsze produkty kosmetyczne na bazie liposomów zostały wprowadzone przez firmy Dior i L'Oréal w latach 1986-1987 [Souto i in. 2008, Asthiani i in. 2016]. Innowacyjność w zastosowaniu preparatów kosmetycznych zwiększyło zainteresowanie produktami typu nanokosmetycznego [Nanda i in. 2016]. Ostatnio wzrosło zainteresowanie liposomami używanymi w żelach i kremach, m.in. do mycia skóry. Obserwuje się również zwiększone zainteresowanie tymi strukturami w dermatotologii i farmakoterapii [Arakane i in. 1993]. Liposomy zostały skonstruowane tak, aby ułatwiać ciągłe dostarczanie molekuł leczniczych i odżywczych powodujących m.in. regenerację epidermy [Souto i in. 2008]. Sposób działania liposomów, ze względu na powinowactwo ich dwuwarstwowej struktury do błony komórkowej, umożliwia przeniesienie zamkniętych w ich wnętrzu związków do komórki [Arakane i in. 1993]. Zauważono podobieństwo lipidowej struktury liposomów i komórek ludzkiej skóry, co znalazło zastosowanie w dermatologii i kosmetologii. Dla rozszerzenia zastosowania nanotechnik obecnie poszukuje się 
nowych ścieżek trans-epidermalnych mogących być drogą do przenoszenia zawartych w liposomach substancji aktywnych do komórki [Raj i in. 2012].

Liposomy mają różnorodne zastosowanie. Występują w produktach do pięlegnacji skóry, zapobiegając procesom starzenia się. Stanowią nośniki uzupełniające niedobory lipidów, a w szczególności kwasu linolenowego. Liposomy te $\mathrm{w}$ większości są tworzone $\mathrm{z}$ niejonowych powierzchniowo czynnych lipidów [Lasic 1995, Nanda i in. 2016]. Preparat Marinosomes ${ }^{\circledR}$, zawierający liposomy z kwasami thuszczowymi (kwas eikozapentaenowy i kwas dokozaheksaenowy), wykorzystano w zapobieganiu chorobom skóry. Preparat ten jest metabolizowany przez enzymy skórne do przeciwzapalnych i antyproliferacyjnych metabolitów, powodując regenerację, nawilżenie i zmiękczenie skóry [Moussaoui i in. 2002].

Specyficzne antyoksydanty zawarte w liposomach redukują wystąpienie poparzeń spowodowanych przez wtórne promieniowanie ultrafioletowe. Zamknięte w liposomach immunostymulanty oraz molekularne i komórkowe związki detoksyfikujące działają jako punktowe serum depigmentacyjne w zwalczaniu starczych plam, cieni i zmarszczek oraz spowalniają procesy związane ze starzeniem się [Giacomoni 2008].

Opracowane na bazie liposomów preparaty kosmetyczne pojawiające się na rynku stają się nową klasą produktów upiększających i korzystnie wpływających na samopoczucie. Te nanostruktury w kombinacji z naturalnymi składnikami mogą pomagać w pielęgnacji urody dzięki właściwościom przeciwstarzeniowym, nawilżającym, antycelulitycznym i przeciwmikrobowym [Chanchal i Swarnlata 2008].

Fosfatydylocholina - jeden z głównych składników liposomów - ze względu na własności kondycjonujące i wygładzające jest szeroko stosowana w środkach kosmetycznych do pielęgnacji skóry [Souto i Müller 2008]. W przypadku wysuszonej i zniszczonej egzemą skóry substancje zawarte w liposomach działają synergistycznie z proteinami, lipidami i węglowodanami, pomagając odzyskać skórze pełną funkcjonalność i wygląd. Ponadto liposomy mogą przenosić witaminy oraz różne fitozwiązki o działaniu terapeutycznym . Zdolność ta znalazła szerokie zastosowanie w dermatologii [Nastruzzi i in. 1993]. Liposomy oprócz funkcji przenoszenia substancji do miejsca docelowego, zwiększają penetrację, rozpuszczalność, stabilność oraz przedłużają efekt działania substancji. Mogą redukować toksyczność, zwiększać kontrolę farmakokinetyczną i farmakodynamiczną, czyniąc produkt efektywnym [Asthiani i in. 2016]. Liposomy uzyskane $\mathrm{z}$ fosfolipidów pochodzących z jaja kurzego mają 1,5 raza większą skuteczność niż z soi w nawilżeniu skóry [Laouini i in. 2012].

Filtry promieniowania UV zamknięte w nanostrukturach dzięki rozpraszaniu oraz odbijaniu promieniowania UV mogą być stosowane jako produkty kosmetyczne przeznaczone do ochrony suchej skóry [Silki i in. 2016]. Nowoczesne kremy przeciwsłoneczne $\mathrm{z}$ mineralnymi filtrami zawierają nanomateriały $\mathrm{z}$ nierozpuszczalnymi tlenkami cynku, tytanu, cyrkonu i ceru zwiększające wskaźnik ochrony przed promieniowaniem [Wawrzyńczak i in. 2016]. Zastosowanie no- 
śników lipidowych w opracowywaniu składu kremów słonecznych poprawiło ich walory estetyczne, stabilność i efektywność [Yadav i in. 2016].

Dzięki zastosowaniu liposomów w farmakologii i kosmetologii możliwe jest przenikanie przez skórę różnych kremów, roztworów, żeli i maści [Fang i in. 2006]. Ponadto zwiększona rozpuszczalność nanokryształów pozwala na lepszą penetrację poszczególnych jej warstw. Substancje aktywne, m.in. flawonoidy, luteina, $\beta$-karoten, koenzym Q10 i wiele innych biozwiązków produkowanych w formie nanokryształów, wyraźnie zwiększają ich dostępność [Shegokar 2016]. Liposomy w znacznym stopniu zwiększają efektywność działania kremów [Rigano i Lionetti 2016]. Te nanostruktury zastosowano w produkcji pasty do zębów, żeli, niezmywalnych filtrów słonecznych, perfum, odżywek do włosów, płynów do mycia skóry, szminek i innych kosmetyków upiększających, jak również nawilżaczy, maści i antybiotyków. Stanowią nośnik substancji aktywnych w innowacyjnych produktach kosmetycznych i farmaceutycznych [Nanda i in. 2016, Silki i in. 2016].

\section{Podsumowanie}

Liposomy jako nośniki substancji biologicznie czynnych zajmują istotne miejsce $\mathrm{w}$ wielu dziedzinach nauki. Jako nośniki lipidowe zwiększają efektywność i stabilność biozwiązków o wymiarze nano. Uwzględniając konieczność użycia w ich tworzeniu bezpiecznych dla zdrowia biodegradowalnych i biokompatybilnych fitozwiązków, mogą znaleźć szerokie zastosowanie w farmacji i kosmetyce. W przyszłości mogą stanowić jedną z obiecujących metod pielęgnacji skóry i leczenia wybranych jednostek chorobowych oraz przyczynić się do opracowania nowych produktów oraz rozwoju skuteczniejszych metod fitoterapeutycznych.

\section{Bibliografia}

Akbarzadeh A., Zarghami N., Mikaeili H., Asgari D., Goganian A.M., Khiabani H.K., Samiei M., Davaran S., 2012. Synthesis, characterization and in vitro evaluation of novel polymer-coated magnetic nanoparticles for controlled delivery of doxorubicin. Nanotechnol. Sci. Appl. 5, 13-25. https://doi.org/10.2147/NSA.S24328

Arakane K., Hayashi K., Naito N., Iwanaga K., Yamashita S., Oku N., 1993. Liposomes: the longterm stability and the topical effect to the skin. J. Soc. Cosmet. Chem. Japan 27(3), 216-226. https://doi.org/10.5107/sccj.27.216

Asthiani H.R.A., Bishe P., Lashgari N.A., Nilforoushzadeh M.A., Zare S., 2016. Liposomes in Cosmetics. J. Skin Stem Cell. 3(3), 1-6, e6581. https://doi.org/10.5812/jssc.65815

Chanchal D., Swarnlata S., 2008. Novel approaches in herbal cosmetics. J. Cosmet. Dermatol. 7(2), 89-95. https://doi.org/10.1111/j.1473-2165.2008.00369.x

Coragliotti A., Franklin S., Day A.G., Decker S.M., Terra V., Holdings I., 2015. Microalgal polysaccharide compositions. U.S. Patent 8, 927, 522.

Costa R., Santos L., 2017. Delivery systems for cosmetics - From manufacturing to the skin of natural antioxidants. Powder Technol. 322, 402-416. https://doi.org/10.1016/j.powtec.2017.07.086

Dąbrowska M., Zielińska A., Nowak I., 2015. Produkty utleniania lipidów jako potencjalny problem zdrowotny oraz analityczny. Chemik 69(2), 89-91. 
Fang J.Y., Hwang T.L., Huang Y.L., 2006. Liposomes as vehicles for enhancing drug delivery via skin routes. Curr. Nanosci. 2(1), 55-70.

Gazit E., 2007. Plenty of room for biology at the bottom: an introduction to bionanotechnology. Im. Coll. Press. 1, 1-15.

Giacomoni P.U., 2008. Advancement in skin aging: the future cosmeceuticals. Clin. Dermatol. 26(4), 364-366. https://doi.org/10.1016/j.clindermatol.2008.01.006

Goik U., Załębska-Żyłka I., Pietrzycka A., 2015. Liposomy jako nośniki substancji aktywnych przenoszonych w głąb skóry. Engin. Biomat. 18, 130, 27-39.

Hafez I.M., Ansell S., Cullis P.R., 2000. Tunable pH-sensitive liposomes composed of mixtures of cationic and anionic lipids. Biophys. J. 79(3), 1438-1446. https://doi.org/10.1016/S00063495(00)76395-8

Jankowski A., Sarecka-Hujar B., Wysocka J., 2011. Liposomy - postać modyfikująca transport substancji aktywnych przez skórę. Część 1. Zastosowanie w transporcie leków o działaniu miejscowym. Ann. Acad. Med. Siles. 65(4), 38-44.

Jung A., 2014. Nanocząstki w zastosowaniach medycznych - kierunek przyszłości? Pediatr. Med. Rodz. 10(2), 104-110.

Kasetvatin C., Rujivipat S., Tiyaboonchai W., 2015. Combination of elastic liposomes and low frequency ultrasound for skin permeation enhancement of hyaluronic acid. Colloids Surf. B 135, 458-464. https://doi.org/10.1016/j.colsurfb.2015.07.07

Kawai K., Kaneko K., Kawakami H., Yonezawa T., 2011. Bioinspired choline-like ionic liquids: their penetration ability through cell membranes and application to SEM visualization of hydrous samples. Langmuir 27(16), 9671-9675. https://doi.org/10.1021/la201914h

Kijowski J., Lesnierowski G., Cegielska-Radziejewska R., 2013. Jaja cennym źródłem składników bioaktywnych. Żywn. Nauka Technol. Jakość 20(5), 29-41.

Kim S.J., Kwon S.S., Jeon S.H., Yu E.R., Park S.N., 2014. Enhanced skin delivery of liquiritigenin and liquiritin-loaded liposome-in-hydrogel complex system. Int. J. Cosmet. Sci. 36(6), 553-560. https://doi.org/10.1111/ics.12156

Laouini A., Jaafar-Maalej C., Limayem-Blouza I., Sfar S., Charcosset C., Fessi H., 2012. Preparation, characterization and applications of liposomes: state of the art. J. Colloid Sci. Biotechnol. 1(2), 147-168. https://doi.org/10.1166/jcsb.2012.1020

Lasic D.D., 1995. Applications of Liposomes. W: R. Lipowsky, E. Sackmann (red.), Handbook of Biological Physics, Vol. 1. Elsevier Science B.V., Amsterdam-Boston-HeidelbergLondon-New York-Oxford-Paris-San Diego-San Francisco-Singapore-Sydney-Tokyo, 491-519.

Li X.J., Schick M., 2001. Theory of tunable $\mathrm{pH}$-sensitive vesicles of anionic and cationic lipids or anionic and neutral lipids. Biophys. J. 80(4), 1703-1711. https://doi.org/10.1016/S00063495(01)76141-3

Lopez-Sanchez J.A., Dimitratos N., Hammond C., Brett G.L., Kesavan L., White S., Miedziak P., Tiruvalam R., Jenkins R.L., Carley A.F., Knight D., Kiely C.J., Hutchings G.J., 2011. Facile removal of stabilizer-ligands from supported gold nanoparticles. Nat. Chem. 3(7), 551-556.

Łukasiewicz M., 2012. Układy liposom-polimer jako nośniki białek zakotwiczonych przez GPI. Zesz. Nauk. Tow. Dokt. UJ. Nauki Ścisłe 5, 57-75.

Meybeck A., Michelon P., Montastier C., Redziniak G., Moet-Hennessy R., 1991. Pharmaceutical composition, in particular dermatological or cosmetic, comprising hydrous lipidic lamellar phases or liposomes containing a retinoid or a structural analogue thereof such as a carotenoid. U.S. Patent 5,034,228.

Mitura S., Mitura K., Niedzielski P., Louda P., Danilenko V., 2006. Nanocrystalline Diamond, its synthesis, properties and applications, J. Achiev. Mater. Manuf. Eng. 16(1-2), 9-16. https://www.researchgate.net/publication/41619741

Moussaoui N., Cansell M., Denizot A., 2002. Marinosomes ${ }^{\circledR}$, marine lipidbased liposomes: Physical characterization and potential application in cosmetics. Inter. J. Pharm. 242(1-2), 361-365. https://doi.org/10.1016/S0378-5173(02)00217-X

Murray R.K., Granner D.K., Mayes P.A., Rodwell V.W., 1994. Biochemia Harpera. Wyd. Lek. PZWL, Warszawa. 
Nanda S., Nanda A., Lohan S., Kaur R., Sihgh B., 2016. Chapter 3 - Nanocosmetics: performance enhancement and safety assurance. W: A.M. Grumezescu (red.), Nanobiomaterials in galenic formulations and cosmetics applications of nanobiomaterials. William Andrew Publishing, Norwich, NY, 47-67. https://doi.org/10.1016/B978-0-323-42868-2.00003-6

Nastruzzi C., Esposito E., Menegatti E., Walde P., 1993. Use nano stability of liposomes in dermatological preparations. J. Appl. Cosmetol. 11, 77-91.

Orzechowska A., Szymańska R., 2016. Nanotechnologia w zastosowaniach biologicznych wprowadzenie. Wszechświat 117(01-03), 60-69.

Park P.J., Jung W.K., Nam K.S., Shahidi F., Kim S.K., 2001. Purification and characterization of antioxidative peptides from protein hydrolysate of lecithin-free egg yolk. J. Am. Oil Chem. Soc. 78(6), 651-656. https://doi.org/10.1007/s11746-001-0321-0

Rahimpour Y., Hamishehkar H., 2012. Liposomes in cosmeceutics. Expert Opin. Drug Deliv. 9(4), 443-455. https://doi.org/10.1517/17425247.2012.666968

Raj S., Jose S., Sumod U.S., Sabitha M., 2012. Nanotechnology in cosmetics: Opportunities and challenges. J. Pharm. Bioallied Sci. 4(3), 186-193. https://doi.org/10.4103/09757406.99016

Rigano L., Lionetti N., 2016. Chapter 6 - Nanobiomaterials in galenic formulations and cosmetics. W: A.M. Grumezescu (red.), Nanobiomaterials in galenic formulations and cosmetics applications of nanobiomaterials. William Andrew Publishing, Norwich, NY, 121-148. https://doi.org/10.1016/B978-0-323-42868-2.00006-1

Sarecka-Hujar B., Jankowski A., Wysocka J., 2011. Liposomy - postać modyfikująca transport substancji aktywnych przez skórę. Część 2. Zastosowanie w transporcie leków o działaniu ogólnoustrojowym. Ann. Acad. Med. Siles. 654, 45-50.

Shegokar R., 2016. Chapter 4 - What nanocrystals can offer to cosmetic and dermal formulations. W: A.M. Grumezescu (red.), Nanobiomaterials in galenic formulations and cosmetics applications of nanobiomaterials. William Andrew Publishing, Norwich, NY, 69-97. https://doi.org/10.1016/B978-0-323-42868-2.00004-8

Schiemann G., 2005. Nanotechnology and nature: on two criteria for understanding their relationship. HYLE Internat. J. Phil. Chem. 11(1), 77-96.

Siepka E., Bobak L., Trziszka T., 2010. Frakcjonowanie żółtka w celu pozyskiwania preparatów wzbogaconych w substancje biologicznie aktywne. Żywn. Nauk. Technol. Jakość 17(6), $158-167$.

Silki S.V., Piryanka C., Asati J.S., 2016. Chapter 5 - Role of liposomal drug-delivery system in cosmetics. W: A.M. Grumezescu (red.), Nanobiomaterials in galenic formulations and cosmetics applications of nanobiomaterials. William Andrew Publishing, Norwich, NY, 93-120. https://doi.org/10.1016/B978-0-323-42868-2.00005-X

Soni V., Chandel S., Jain P., Asati S., 2016. Chapter 5 - Role of liposomal drug-delivery system in cosmetics. W: A.M. Grumezescu (red.), Nanobiomaterials in galenic formulations and cosmetics applications of nanobiomaterials. William Andrew Publishing, Norwich, NY, 93-120. https://doi.org/10.1016/B978-0-323-42868-2.00005-X

Souto E.B., Müller R.H., 2008. Challenging cosmetics-solid lipid nanoparticles (SLN) and nanostructured lipid carriers (NLC). W: J.W. Wiechers (red.), Science and application of skin delivery systems. Allured Publ. Corp., IL, USA, 227-250.

Swami H., Kataria M.K., Bilandi A., Kour P., Bala S., 2015. Liposome: an art for drug delivery. IJPSL $5(2), 523-530$.

Van Tran V., Moon J.Y., Lee Y.C., 2019. Liposomes for delivery of antioxidants in cosmeceuticals: Challenges and development strategies. J. Control. Release 300, 114-140 https://doi.org/10.1016/j.jconrel.2019.03.003

Wawrzyńczak A., Feliczak-Guzik A., Nowak I., 2016. Chapter 2 - Nanosunscreens: from nanoencapsulated to nanosized cosmetic active forms. W: A.M. Grumezescu (red.), nanobiomaterials in galenic formulations and cosmetics applications of nanobiomaterials. William Andrew Publishing, Norwich, NY, 25-46. https://doi.org/10.1016/B978-0-323-42868-2.00002-4 
Wettstein H.R., Machmüller A., Kreuzer M., 2000. Effects of raw and modified canola lecithins compared to canola oil, canola seed and soy lecithin on ruminal fermentation measured with rumen simulation technique. Anim. Feed Sci Tech, 85(3-4), 153-169. https://doi.org/10.1016/S03778401(00)00149-8

Yadav H.K.S., Kasina S., Raizaday A., 2016. Chapter 9 - Sunscreens. W: A.M. Grumezescu (red.), Nanobiomaterials in galenic formulations and cosmetics applications of nanobiomaterials. William Andrew Publishing, Norwich, NY, 201-230. https://doi.org/10.1016/B978-0-323-42868-2.00009-7

Yu X., Liu Z., Janzen J., Chafeeva I., Horte S., Chen W., Kainthan R.K., Kizhakkedathu J.N., Brooks D.E., 2012. Polyvalent choline phosphate as a universal biomembrane adhesive. Nat. Mater. 11(5), 468-476. https://doi.org/10.1038/nmat3272 


\title{
Paulina Leśniak $\mathbb{B}^{1}$, Małgorzata Manastyrska $\mathbb{D}^{2}$, Jose Luis Valverde Piedra $\mathbb{B}^{3}$, Marlena Księżarczyk ${ }^{4}$
}

\section{Glifosat - zagrożenie dla zdrowia ludzi i zwierząt}

Glyphosate - threat to human and animal health

\begin{abstract}
Wstęp
Glifosat należy do herbicydów najpowszechniej stosowanych na świecie. Jest to organiczny związek chemiczny z grupy fosfonianów ( $\alpha$-aminofosfonianów), w którym jeden $\mathrm{z}$ atomów wodoru grupy metylowej połączonej bezpośrednio $\mathrm{z}$ fosforem zastapiono glicyną. Głównym produktem biodegradacji glifosatu jest kwas aminometylofosfonowy (AMPA), związek o podobnym do glifosatu profilu toksyczności [Borggaard i Gimsing 2008]. Glifosat jest nieselektywnym środkiem chwastobójczym w konwencjonalnych uprawach, natomiast w uprawach roślin transgenicznych stosuje się go jako herbicyd selektywny. Zwalcza on rośliny jednoroczne i wieloletnie trawy oraz rośliny dwuliścienne. Stosowany jest także do zwalczania traw bylinowych w ogrodach i lasach, a także nadbrzeżnych chwastów i zbędnej roślinności wodnej. Niestety może to prowadzić bezpośrednio do skażenia nim zbiorników wodnych [Sopińska i in. 2000]. W celu poprawy skuteczności działania glifosatu stosuje się modyfikacje jego cząsteczki. W preparatach pestycydowych występuje on najczęściej jako sól izopropylowa oraz sól amonowa, sodowa, potasowa i sól trimetylosiarczanu [Kwiatkowska i in. 2013].

Znane na całym świecie preparaty, których główną substancją czynną jest glifosat (Avans Premium 360 SL, Dominator 360 SL, Roundup 360), zawierają także surfaktanty, zwiększające skuteczność działania herbicydu. Substancje te mogą być bardziej toksyczne od samego glifosatu, pogłębiając działanie preparatów do zwalczania niepożądanej roślinności nawet 17-32-krotnie [Grygiel i in. 2012, Martini $i$ in. 2012]. Wchłanianie glifosatu przez rośliny rozpoczyna się tuż po ich opryskaniu i trwa ok. $3 \mathrm{~h}$. Wnika on do roślin poprzez ich zielone części (liście,

\footnotetext{
${ }^{1}$ Uniwersytet Przyrodniczy w Lublinie, Wydział Medycyny Weterynaryjnej, Zakład Farmakologii, Toksykologii i Ochrony Środowiska, paulina.lesniak91@wp.pl

${ }^{2}$ Uniwersytet Przyrodniczy w Lublinie, Wydział Medycyny Weterynaryjnej, Katedra Fizjologii Zwierząt

${ }^{3}$ Uniwersytet Przyrodniczy w Lublinie, Wydział Medycyny Weterynaryjnej, Zakład Farmakologii, Toksykologii i Ochrony Środowiska

${ }^{4}$ Uniwersytet Przyrodniczy w Lublinie, Wydział Medycyny Weterynaryjnej, Studenckie Koło Toksykologii Weterynaryjnej
} 
zielone pędy, niezdrewniałą łodygę), a przemieszczając się w roślinie przez układ naczyniowy, dociera do części podziemnych, takich jak korzenie, rozłogi, bulwy, cebule i kłącza, powodując ich zamieranie [Pieniążek i in. 2003]. Rozprowadzanie glifosatu w roślinie odbywa się w sposób samoistny, ponieważ herbicyd ten ogranicza działanie tkanki asymilującej dwutlenek węgla w liściach zielonych. Prowadzi to do zahamowania procesu fotosyntezy i wysuszania rośliny w wyniku zamknięcia aparatów szparkowych i ograniczenia procesów oddechowych [Kwiatkowska i in. 2013].

Głównym mechanizmem działania glifosatu jest hamowanie aktywności syntetazy EPSP (5-enolopirogronoszikimo-3-fosforan). Powoduje to zatrzymanie tworzenia przez rośliny aminokwasów aromatycznych, takich jak: fenyloalanina, tyrozyna i tryptofan, które są bardzo istotne dla wzrostu roślin [Franz i in. 1997].

\section{Wady i zalety stosowania glifosatu}

Statystyki pokazują, iż wykorzystanie glifosatu z roku na rok wzrasta, pomimo świadomości zagrożeń, jakie są z nim związane. Dzięki modyfikacjom genetycznym uzyskano grupę roślin tolerujących glifosat (GMO - rośliny genetycznie modyfikowane) - można stosować na te rośliny opryski, bez obaw ich zniszczenia, co jest bez wątpienia znacznym ułatwieniem dla rolników. Ponadto szacuje się, iż zastosowanie herbicydów redukuje koszty uprawy roślin trzykrotnie, gdyż całkowicie eliminuje niegdyś wykorzystywaną w tym celu pracę fizyczną. Uprawa roślin z grupy GMO pozornie wydaje się być wygodna. Rolnicy zwykli stosować większe ilości glifosatu w uprawie tych roślin, nie mając do końca świadomości konsekwencji swojego lekkomyślnego postępowania, tj. występowania pozostałości związku w tych roślinach. Rośliny wrażliwe na herbicydy, m.in. w Indiach, pokrywa się plastikowymi koszami i dopiero po osłonięciu stosuje się oprysk. Wszystkie te zabiegi mają służyć zwiększeniu wydajności upraw i tym samym redukcji jej kosztów [Varshney 2018].

Do niewątpliwych wad zastosowania glifosatu w rolnictwie należy fakt, iż rocznie odnotowuje się ok. 3 milionów zatruć pestycydami na świecie [Kwiatkowska $i$ in. 2013]. Cox sugeruje, iż ludzie są narażeni na działanie glifosatu po bezpośrednim kontakcie (ryzyko zawodowe rolników) z substancją lub skażoną glebą i wodą (picie i kąpiele), bądź też po spożyciu zanieczyszczonego jedzenia $i$ wody [Cox 1998]. Badania przeprowadzone na terenie Argentyny, Brazylii i USA wykazały obecność glifosatu w soi oraz w różnych typach zbiorników wodnych, przy czym trwałość glifosatu w wodzie oszacowano na 60 dni [Dias $i$ in. 2019]. Badania stężenia glifosatu $i$ jego pochodnych, $t j$. metyloglifosatu (Me-Glyp) i kwasu aminometylofosfonowego (AMPA), w moczu psów i kotów niemających bezpośredniego kontaktu $\mathrm{z}$ glifosatem przeprowadzone w USA wykazały, iż stężenie Glyp + Me-Glyp + AMPA w moczu kotów było dwukrotnie wyższe niż u psów [Karthikraj i Kannan 2019]. 
Raport Fundacji Konsumentów i Programu FoodRentgen dotyczący badania kaszy gryczanej wnosi, iż istnieją na rynku marki tego produktu zawierające pozostałości glifosatu przekraczające nawet 3-7-krotnie obowiązującą normę największej dopuszczalnej zawartości herbicydów w żywności $(0,1 \mathrm{mg} / \mathrm{kg} \mathrm{wg}$ Rozporządzenia WE nr 369/2005 z późn. zm.). Najbardziej prawdopodobną przyczyną występowania pozostałości glifosatu w kaszy jest tzw. proces desykacji, czyli powszechnie stosowana metoda wykorzystywana przez rolników do osuszania ziarna wyżej wymienionym związkiem [FoodRentgen 2019b]. Powyższe wyniki potwierdzają wcześniej wysuniętą tezę o zagrożeniu ekspozycji na glifosat nie tylko w trakcie stosowania oprysków i po bezpośrednim kontakcie, ale również na drodze spożycia skażonej nim żywności i wody [Torretta i in. 2018].

\section{Wpływ glifosatu na ludzi}

Organizm ludzki narażony jest na wnikanie glifosatu poprzez drogi oddechowe, drogą pokarmową oraz przez skórę. Sugeruje się, iż zatrucie glifosatem przez drogi oddechowe jest mało toksyczne, gdyż nie jest on związkiem lotnym. Z kolei Roundap, preparat pestycydowy charakteryzujący się większą toksycznością od glifosatu (17-32 razy), może się dostawać do dróg oddechowych w trakcie stosowania oprysków i stwarza wtedy duże ryzyko zatrucia [Kwiatkowska $\mathrm{i}$ in. 2013].

Głównymi objawami zatrucia drogą oddechową są wówczas: ospałość, zaburzenia oddychania, przekrwione oczy i spadek masy ciała. W badaniu patomorfologicznym stwierdzono przekrwienie i obrzęk płuc, stany zapalne przewodu pokarmowego, uszkodzenia nerek i wątroby [Barski i Spodniewska 2014].

Badania wykazały, iż u farmerów, którzy nie stosowali rękawiczek w pracy $\mathrm{z}$ użyciem wyżej opisanej substancji, występowało większe jej stężenie w moczu w porównaniu z tymi, którzy rękawice stosowali, co wynikało z przenikania glifosatu drogą kontaktu bezpośredniego przez skórę. Sugeruje się, iż ok 3-4\% objętości glifosatu mającego styczność ze skórą przenika w głąb organizmu [ATSDR 2019].

Koller [2012] udowadnia, że 20-minutowa ekspozycja na 10-20 mg/l glifosatu powoduje uszkodzenie DNA w komórkach epitelium. Badania Campbella [2014] dowiodły, iż problemy z utrzymaniem ciąży kobiet powodowane są toksycznym oddziaływaniem glifosatu na komórki JEG-3 łożyska oraz syntezę estrogenu (dochodzi do zaburzeń w poziomie aromatazy i mRNA).

Badania z 2018 r. przeprowadzone w Argentynie wykazały zależność pomiędzy wysokimi stężeniami glifosatu w glebie oraz pyle a ronieniami i wadami wrodzonymi u dzieci rolników [Malkan 2020].

Dodatkowo sugeruje się, iż glifosat zmniejsza biodostępność serotoniny, co może objawiać się zaburzeniami emocjonalnymi, a także zaburzeniami snu 
i koncentracji. Glifosat wiąże również cynk i żelazo, wywołując niedobory tych elementów w organizmie wraz z ich następstwami [FoodRentgen 2019a].

Badania Jayasuman i in. [2014] wykazały, iż glifosat uczestniczy w transporcie metali ciężkich do nerek, co prowadzi do ich przewlekłej choroby. Z kolei badania, przeprowadzone przez Malkan i in. [2020], sugerują, iż Roundap predysponuje do występowania chłoniaka (NHL). Badania Kollera i in. [2012] na wyizolowanym nabłonku ludzkiej jamy ustnej polegające na jego inkubacji w roztworze Roundapu w stężeniu $0,01 \mathrm{~g} / 1$ (20 min inkubacji) wykazały istotne zmiany w komórkach, co może wskazywać na karcynogenny wpływ glifosatu.

\section{Wpływ glifosatu na środowisko}

Ze względu na swoje właściwości glifosat jest powszechnie wykorzystywany w rolnictwie. Jak się okazuje, skutki jego działania nie ograniczają się jedynie do roślin, a mają znacznie szerszy zasięg. Jego okres półtrwania w środowisku wynosi od 2 do 197 dni, natomiast za przeciętny czas zachowania aktywności w środowisku uznaje się 47 dni. Herbicydy na bazie glifosatu mogą zanieczyszczać gleby w miejscu aplikacji i wokół niego [Van Bruggen i in. 2018]. Ze względu na silne powinowactwo do stałych powierzchni glifosat zanieczyszcza również cząsteczki pyłu i powietrze w środowisku. Badania pokazują, iż pozostałości glifosatu wykrywano w wodzie deszczowej i powietrzu na obszarach rolniczych [Chang i in. 2011]. Początkowo herbicydy na bazie glifosatu nie były uważane za potencjalne źródło zanieczyszczenia wód powierzchniowych i gruntowych ze względu na jego ograniczoną mobilność z gleby [Sihtmäe i in. 2013, Monsanto 2014]. Jednak glifosat i jego metabolity często są wykrywane jako zanieczyszczenia w rzekach i wodach powierzchniowych [Gasnier i in. 2009]. Chociaż glifosat i AMPA są silnie związane z gliną i materią organiczną, część $\mathrm{z}$ nich może przenosić się do wód gruntowych przez opady deszczu [Maqueda $\mathrm{i}$ in. 2017, Rendón-von Osten i in. 2017]. Nie tylko deszcz, ale także erozja cząstek gleby w wodach powierzchniowych są odpowiedzialne za przenoszenie glifosatu, który pozostaje $\mathrm{w}$ fazie rozpuszczonej lub rozdrobnionej i osiada w osadach dennych [Yang i in. 2015, Wang i in. 2016, Maqueda i in. 2017].

\section{Wpływ glifosatu na zdrowie zwierząt}

Liczne badania dowodzą, iż glifosat oraz jego pochodne działają teratogennie, genotoksycznie oraz wywołują liczne toksyczne skutki w sferze reprodukcji [Robinson 2012]. Krüger i in. [2014] wykazali doświadczalnie, że glifosat dodany do paszy dla prosiąt przyczynia się do powstania wad rozwojowych w stadzie, powodując m.in. atrofię uszu, deformację kręgosłupa czy czaszki. W badaniach prowadzonych na pszczołach wykazano, że glifosat zaburza funkcjonowanie ich systemu nawigacji (zakłóca uczenie się układów przestrzen- 
nych) [Balbuena i in. 2015], może też osłabiać ich wrażliwość do wykrywania nektaru i zdolność uczenia się [Herbert i in 2014].

Wyniki badań Sopińskiej, Grochoła i Niezgody [Sopińska i in. 2000] wskazują, że Roundup, zawierający glifosat, jest toksyczny dla ryb i powoduje spadek aktywności ich układu immunologicznego. Inne doświadczenie, przeprowadzane na na Caenorhabditis elegans, wskazuje, iż wzrasta aktywność reaktywnych form tlenu, które prowadzą do wytworzenia stresu oksydacyjnego i inhibicji funkcji mitochondriów. Tym zmianom towarzyszyły również objawy neurodegeneracyjne w neuronach GABA i DOPA-ergicznych. Na tej podstawie autorzy wnioskują, iż glifosat może przyczyniać się do występowania chorób neurodegeneracyjnych, np. choroby Parkinsona u ludzi [Zimmer 2018].

\section{Podsumowanie}

Preparaty herbicydowe na bazie glifosatu mogą być silnie szkodliwe zarówno dla ludzi, jak i zwierząt. Powszechność ich stosowania oraz ogólna dostępność skłania rolników do częstego sięgania po herbicydy na bazie glifosatu. Niestety może to prowadzić do tragicznych konsekwencji dla środowiska, wód gruntowych, powierzchniowych, gleb, roślin, a przez to pośrednio dla zwierząt oraz konsumentów, czyli ludzi. Konieczne jest uświadamianie rolników na temat toksyczności tego typu preparatów oraz zachęta do kupna bezpiecznych herbicydów.

\section{Bibliografia}

ATSDR, 2019. Toxicological profile for glyphosate. Draft for Public Comment. https://www.atsdr.cdc.gov/toxprofiles/tp214.pdf [dostęp: 30.03.2020].

Balbuena M.S., Tison L., Hahn M.L., Greggers U., Menzel R., Farna W.M., 2015. Effects of sublethal doses of glyphosate on honeybee navigation. J. Exp. Biol. 218(17), 2799-2805.

Barski D., Spodniewska A., 2014. Toksykologia weterynaryjna - wybrane zagadnienia. Skrypt dla studentów weterynarii. Wyd. UWM, Olsztyn, 163.

Borggaard O.K., Gimsing A.L., 2008. Fate of glyphosate in soil and the possibility of leaching to ground and surface waters: a review. Pest Manag. Sci. 64, 441-456.

Campbell A., 2014. Glyphosate: Its effects on humans. Altern. Ther. Health Med. 20(3), 9-11.

Chang F.C., Simcik M.F., Capel P.D., 2011. Occurrence and fate of the herbicide glyphosate and its degradate aminomethylphosphonic acid in the atmosphere. Environ. Toxicol. Chem. 30, 548-555.

Cox C., 1998. Glyphosate (Roundup). J. Pestic. Ref. 18(3), 3-17.

Dias M., Rocha R., Soares R.R., 2019. Glyphosate use in agriculture and birth outcomes of surrounding populations. IZA Discussion Paper No. 12164, 8.

FoodRentgen, 2019a. Glifosat: Jego wpływ na człowieka. FoodRentgen, http://foodrentgen.eu/pl/pestycydy-w-zywnosci/69-glifosat-i-jego-wplyw-na-czlowieka [dostęp: 28.03.2020].

FoodRentgen, 2019b. Prześwietlamy: Kasza gryczana. Raport. FoodRentgen, https://www.foodrent-gen.eu/pl/raport-kasze-gryczane [dostęp: 30.03.2020].

Franz J.E., Mao M.K., Sikorski J.A., 1997. Glyphosate a Unique Global Herbicyde. ACS Monograph 189. American Chemical Society, Washington DC. 
Gasnier C., Dumont C., Benachour N., Clair E., Chagnon M.-C., Séralini G.-E., 2009. Glyphosatebased herbicides are toxic and endocrine disruptors in human cell lines. Toxicology 262, 184-191.

Grygiel K., Sadowski J., Snopczyński T., Wysocki A., 2012. Pozostałości herbicydów w płodach rolnych i glebie. J. Ecol. Health 16(4), 159-163.

Herbert L.T., Vazquez D.E., Arenas A., Farina W.M., 2014. Effects of field-realistic doses of glyphosate on honeybee appetitive behaviour. J. Exp. Biol. 217(19), 3457-3464.

Jayasumana C., Gunatilake S., Senanayake P., 2014. Glyphosate, hard water and nephrotoxic metals: are they the culprits behind the epidemic of chronic kidney disease of unknown etiology in Sri Lanka. Int. J. Environ. Res. Publ. Health 11(2), 2125-2147. https://doi.org/10.3390/ijerph110202125

Karthikraj R., Kannan K., 2019. Widespread occurrence of glyphosate in urine from pet dogs and cats in New York State. Sci. Total Environ. 790-795. https://doi.org/10.1016/j.scitotenv.2018.12.454

Koller V.J., Furhacker M., Nersesyan A., Misik M., Eisenbauer M., Knasmueller S. 2012. Cytotoxic and DNA-damaging properties of glyphosate and Roundup in human-derived buccal epithelial cells. Arch. Toxicol. 86, 805-813. https://doi.org/10.1007/s00204-012-0804-8

Krüger M., Schrödl W., Pedersen I., 2014. Detection of Glyphosate in Malformed Piglets. J. Environ. Anal. Toxicol. 4(5). http://dx.doi.org/10.4172/2161-0525.1000230

Kwiatkowska M., Jarosiewicz P., Bukowska B., 2013. Glifosat i jego preparaty - toksyczność, narażenie zawodowe i środowiskowe. Med. Pr. 64(5), 717-729. https://doi.org/10.13075/mp.5893.2013.0059

Malkan S., 2020. Glyphosate fact sheet: Cancer and other health concerns. U.S. Right to Know, https://usrtk.org/pesticides/glyphosate-health-concerns [dostęp: 28.03.2020].

Maqueda C., Undabeytia T., Villaverde J., Morillo E., 2017. Behaviour of glyphosate in a reservoir and the surrounding agricultural soils. Sci. Total Environ. 593, 787-795.

Martini C.N., Gabrielli M., Vila M.C. del, 2012. A commercial formulation of glyphosate inhibits proliferation and differentiation to adipocytes and induces apoptosis in 3T3-L1 fibroblasts. Toxicol. In Vitro 26, 1007-1013. https://doi.org/10.1016/j.tiv.2012.04.017

Monsanto, 2014. Backgrounder: Glyphosate and water quality. https://monsanto.com/app/ uploads/2017/06/glyphosate-and-water-quality.pdf

Pieniążek D., Bukowska B., Duda W., 2003. Glifosat - nietoksyczny pestycyd? Med. Pr. 54(6), 579-583.

Rendón-von Osten J., Dzul-Caamal R., 2017. Glyphosate residues in groundwater, drinking water and urine of subsistence farmers from intensive agriculture localities: a survey in Hopelchén, Campeche, Mexico. Int. J. Environ. Res. Public Health 14(6), 595. https://doi.org/10.3390/ijerph14060595

Robinson C., 2012. Teratogenic Effects of Glyphosate-Based Herbicides: Divergence of Regulatory Decisions from Scientific Evidence. J. Environ. Anal. Toxicol. 1(S4). http://dx.doi.org/10.4172/21610525.S4-006

Rozporządzenie (we) nr 396/2005 Parlamentu Europejskiego i Rady z dnia 23 lutego 2005 r. w sprawie najwyższych dopuszczalnych poziomów pozostałości pestycydów w żywności i paszy pochodzenia roślinnego i zwierzęcego oraz na ich powierzchni, zmieniające dyrektywę Rady 91/414/EWG (Dz.U. L 70 z 16.3.2005).

Sihtmäe M., Blinova I., Künnis-Beres K., Kanarbik L., Heinlaan M., Kahru A., 2013. Ecotoxicological effects of different glyphosate formulations. Appl. Soil Ecol. 72, 215-224. https://doi.org/10.1016/j.apsoil.2013.07.005

Sopińska A., Grochoła A., Niezgoda J., 2000. Wpływ wód zanieczyszczonych herbicydem Roundap na organizm ryb. Med. Weter. 56(9), 593-597.

Torretta V., Katsoyianni S.V.L., Viotti P., Rada E., 2018. Critical review of the effects of glyphosate exposure to the environment and humans through the food supply chain. Sustainability 10(4), 950. https://doi.org/10.3390/su10040950

Van Bruggen A., He M., Shin K., Mai V., Jeong K., Finckh M., Morris Jr J., 2018. Environmental and health effects of the herbicide glyphosate. Sci. Total Environ. 616, 255-268. https://doi.org/10.1016/j.scitotenv.2017.10.309 
Varshney V., 2018. Glyphosate use increased 1500\% since genetically modified crops were introduced. Down To Earth, https://www.downtoearth.org.in/blog/food/glyphosate-use-increased1500-since-genetically-modified-crops-were-introduced-61241 [dostęp: 31.03.2020].

Wang S., Seiwert B., Kästner M., Miltner A., Schäffer A., Reemtsma T., Yang Q., Nowak K.M., 2016. (Bio)degradation of glyphosate in water-sediment microcosms - A stable isotope co-labeling approach. Water Res. 99, 91-100. https://doi.org/10.1016/j.watres.2016.04.041

Yang X., Wang F., Bento C.P., Xue S., Gai L., Dam R. van, Mol H., Ritsema C.J., Geissen V., 2015 Short-term transport of glyphosate with erosion in Chinese loess soil - A flume experiment. Sci. Total Environ. 512, 406-414. https://doi.org/10.1016/j.scitotenv.2015.01.071

Zimmer K., 2018. How toxic is the world's most popular herbicide roundup. The Scientists, https://www.the-scientist.com/news-opinion/how-toxic-is-the-worlds-most-popular-herbicideroundup-30308 [dostęp: 30.03.2020]. 


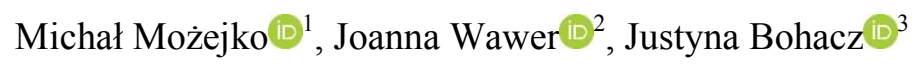

\title{
Dynamika zmian liczebności mikroorganizmów i aktywności enzymatycznej gleb wzbogaconych produktami ubocznymi z przemysłu owocowo-warzywnego
}

\author{
Dynamics of changes in microbial count and enzymatic activity of soils supplemented \\ with by-products from the fruit and vegetable processing industry
}

\begin{abstract}
Wstęp
Gleba jest środowiskiem bytowania mikroorganizmów o specyficznej dynamice procesów biochemicznych [Utobo i Tewari 2015]. Z rolniczego punktu widzenia obfitość materii organicznej w glebie determinuje wzrost i plonotwórczość roślin [Chang i in. 2007]. Gleby użytkowane rolniczo charakteryzują się obniżoną zawartością materii organicznej wynikającą z intensywnej uprawy gleby oraz różnorodnych praktyk nawożenia. Spadek całkowitej zawartości materii organicznej w glebie poniżej tzw. wartości krytycznych (ok. 1-3,4\%) prowadzi do pogorszenia właściwości fizycznych, chemicznych i biologicznych gleby oraz obniża jej produktywność [Innangi i in. 2017]. Wzbogacenie gleby odpadową materią organiczną zwiększa ilość zgromadzonego w niej węgla organicznego oraz poprawia żyzność [Chang i in. 2007]. Obecnie poszukuje się alternatywy dla stosowanych w praktyce rolniczej nawozów konwencjonalnych [Szwed i Bohacz 2014]. Wielu autorów podejmuje się poszukiwania, opracowania oraz wykorzystania niekonwencjonalnych, poprzemysłowych odpadów zwierzęcych i roślinnych na cele nawozowe, a także badania ich wpływu na środowisko glebowe. Odpady pochodzenia zwierzęcego, w tym odpady keratynowe [Korniłłowicz-Kowalska i Bohacz 2005], obok odpadów roślinnych, takich jak odpady z przemysłu tytoniowego [Szwed i Bohacz 2014] oraz wytłoki owocowo-warzywne [Innangi i in. 2017], są wykorzystywane dla celów rolniczych. Jako nawozy mogą być również wykorzystane środki oparte na odpadach organicznych [Meena i in. 2013]. Ponadto wielu autorów bada możliwości po-

\footnotetext{
${ }^{1}$ Uniwersytet Przyrodniczy w Lublinie, Wydział Agrobioinżynierii, Katedra Mikrobiologii

${ }^{2}$ Uniwersytet Medyczny w Lublinie, Wydział Lekarsko-Dentystyczny, Katedra Genetyki Medycznej

${ }^{3}$ Uniwersytet Przyrodniczy w Lublinie, Wydział Agrobioinżynierii, Katedra Mikrobiologii Środowiskowej
} Środowiskowej, michaltomasz.mozejko@gmail.com
\end{abstract}


tencjalnego zastosowania takich odpadów jak komunalne i przemysłowe osady ściekowe [Furczak i Joniec 2007, Santos i in. 2011].

Celem niniejszej pracy była ocena wpływu poprodukcyjnych wytłoków owocowych i warzywnych na mikrobiologiczną aktywność gleb. Liczebność mikroorganizmów i aktywność enzymatyczna są bowiem ekologicznymi wskaźnikami przemian glebowej materii organicznej, na których podstawie można oszacować stan środowiska glebowego [Utobo i Tewari 2015], poziom żyzności [Järvan $i$ in. 2014] oraz relacje w systemie gleba - roślina [Meena $i$ in. 2013].

\section{Material i metodyka}

\section{Material badawczy i charakterystyka gleby}

Materiał badawczy obejmował wytłoki buraczane i jabłkowe z przetwórni owoców i warzyw Kampol-Fruit Sp. z.o.o. w Milejowie (woj. lubelskie). Do badań wykorzystano dwie gleby o różnej zawartości węgla organicznego: rędzinę wytworzoną w epoce kredowej, o składzie granulometrycznym gliny zwykłej (Rendzic Phaeozem) i zawartości $\mathrm{C}_{\text {org }}=24,73 \mathrm{~g} \cdot \mathrm{kg}^{-1}$, oraz glebę bielicową o składzie granulometrycznym piasku gliniastego (Haplic Podzol) i zawartości $\mathrm{C}_{\mathrm{org}}=5,3 \mathrm{~g} \cdot \mathrm{kg}^{-1}$. Próbki obu gleb pochodziły z Gospodarstwa Doświadczalnego w Bezku (Uniwersytet Przyrodniczy w Lublinie). Szczegółową charakterystykę gleb podano w pracach Kraski [2012] oraz Pranagala i in. [2017].

\section{Warunki badań i warianty eksperymentalne}

Doświadczenie laboratoryjne przeprowadzono w 5-litrowych pojemnikach, wypełnionych $0,5 \mathrm{~kg}$ gleby przesianej przez sita (średnica oczek $\varnothing 2 \mathrm{~mm}$ ). Eksperyment prowadzono przez 60 dni w 8 wariantach doświadczalnych różniących się glebą oraz rodzajem i dawką wytłoków:

$\mathrm{R}_{\mathrm{J} / \mathrm{B}-1,5 / 3,0}$ - rędzina wzbogacona dawką 1,5\% lub 3,0\% wytłoków jabłkowych (J) bądź buraczanych (B).

$\mathrm{B}_{\mathrm{J} / \mathrm{B}-1,5 / 3,0}$ - gleba bielicowa wzbogacona dawką 1,5\% lub 3,0\% wytłoków jabłkowych (J) bądź buraczanych (B).

\section{Analizy biochemiczne i mikrobiologiczne}

Aktywność respiracyjną oznaczono według Rühling i Tyler [1973], stosując $0,2 \mathrm{M} \mathrm{NaOH}$ do wiązania wydzielanego z gleby $\mathrm{CO}_{2}$. Aktywność dehydrogenaz oznaczono według Casida i in. [1964], stosując 2,3,5-trifenylotetrazoliowy chlorek (TTC) jako substrat.

Ogólną liczebność bakterii oznaczono za pomocą płytkowej metody wysiewu rozcieńczeń (metoda zalewowa) na podłożu z wyciągiem glebowym o skła- 
dzie: glukoza (1,0 g), $\mathrm{K}_{2} \mathrm{HPO}_{4}(0,5 \mathrm{~g})$, agar (20,0 g), wyciąg glebowy (350 ml), $\mathrm{H}_{2} \mathrm{O}_{\text {dest }}(650 \mathrm{ml})$. Liczebność grzybów oznaczano na podłożu Martina [1950]. Założone hodowle inkubowano w temperaturze $28^{\circ} \mathrm{C}$ (bakterie) i w $26^{\circ} \mathrm{C}$ (grzyby). Wyrosłe kolonie bakteryjne i grzybowe zliczono odpowiednio po 3 i 5 dniach inkubacji. Uzyskane wyniki wyrażono $\mathrm{w} \mathrm{jtk} \cdot \mathrm{kg}^{-1}$ s.m. gleby.

Liczebność mikroorganizmów i aktywność biochemiczną gleb analizowano $\mathrm{w}$ równych odstępach czasu (w dniu 1., 30. i 60. od momentu założenia doświadczenia). Natomiast $\mathrm{pH}$ wytłoków owocowych i warzywnych oraz $\mathrm{pH}$ gleby określono metodą potencjometryczną za pomocą pH-metru CP-501 (Elmetron).

\section{Analiza statystyczna}

Uzyskane wyniki badań poddano analizie statystycznej w oprogramowaniu Microsoft Excel 2016. Współczynnik korelacji liniowej r-Pearsona wyliczono według Puth $\mathrm{i}$ in. [2014]. Istotność statystyczną oszacowano na trzech poziomach istotności: $\alpha=0,1,0,05$ i 0,01 [Puth i in. 2014] i skonfrontowano $\mathrm{z}$ wartościami z tablicy rozkładu t-Studenta dla $\mathrm{n}-2$ stopni swobody.

\section{Wyniki i dyskusja}

\section{Odczyn gleby i pH wytloków}

Zmiany odczynu gleby wzbogaconej w materię organiczną uzależnione są od $\mathrm{pH}$ zastosowanego środka użyźniającego [Angelova i in. 2013]. Nawozy organiczne (np. obornik) efektywniej niż mineralne zwiększają pH gleby. Badania własne wykazały, że wprowadzenie do gleb wytłoków buraczanych i jabłkowych powodowało znaczące różnice odczynu (tab. 1 i 2). Wzbogacona wytłokami

Tabela 1. Wartości pH wytłoków buraczanych i jabłkowych

\begin{tabular}{|c|c|c|}
\hline \multirow{2}{*}{$\mathrm{pH}$} & \multicolumn{2}{|c|}{ Rodzaj wytłoków } \\
\cline { 2 - 3 } & buraczane & jabłkowe \\
\hline $\mathrm{H}_{2} \mathrm{O}$ & $4,43 \pm 0,02$ & $3,53 \pm 0,02$ \\
$\mathrm{KCl}$ & $4,05 \pm 0,02$ & $2,98 \pm 0,01$ \\
\hline
\end{tabular}

rędzina miała odczyn obojętny, a gleba bielicowa kwaśny (tab. 2). Po dodaniu do gleby $(\mathrm{pH}=6,5)$ kompostu i wermikompostu Angelova i in. [2013] zanotowali, że wyższe $\mathrm{pH}$ wermikompostów $(\mathrm{pH}=7,5)$ spowodowało wzrost pierwotnego odczynu gleby. Badania własne wykazały, że obie dawki wytłoków buraczanych i jabłkowych alkalizowały glebę (tab. 2). Efektywniejszy wzrost pH notowano dla wyższych, tj. dawek 3,0\% wytłoków.

Podobne wyniki uzyskali Angelova i in. [2013] dla 10\% stężenia wermikompostu, które efektywniej od jego 5\% dawki zwiększyło pH gleby. Cytowani autorzy sugerują, że mogło być to związane ze wzrostem zawartości węgla orga- 
Tabela 2. Wartości pH gleb wzbogaconych wytłokami buraczanymi i jabłkowymi

\begin{tabular}{|c|c|c|c|}
\hline \multirow{2}{*}{$\begin{array}{c}\text { Wariant } \\
\text { doświadczalny }\end{array}$} & \multicolumn{3}{|c|}{ Termin analizy } \\
\cline { 2 - 4 } & $0(24 \mathrm{~h})$ & $\mathrm{I}(30 \mathrm{dni})$ & $\mathrm{II}(60 \mathrm{dni})$ \\
\hline $\mathrm{R}_{\mathrm{B}-1,5}$ & $7,32 \pm 0,08$ & $7,40 \pm 0,06$ & $7,34 \pm 0,05$ \\
$\mathrm{R}_{\mathrm{B}-3,0}$ & $7,41 \pm 0,04$ & $7,42 \pm 0,04$ & $7,35 \pm 0,02$ \\
$\mathrm{R}_{\mathrm{J}-1,5}$ & $7,40 \pm 0,04$ & $7,41 \pm 0,07$ & $7,41 \pm 0,01$ \\
$\mathrm{R}_{\mathrm{J}-3,0}$ & $7,45 \pm 0,04$ & $7,52 \pm 0,06$ & $7,41 \pm 0,03$ \\
$\mathrm{~B}_{\mathrm{B}-1,5}$ & $5,54 \pm 0,20$ & $5,18 \pm 0,03$ & $5,49 \pm 0,10$ \\
$\mathrm{~B}_{\mathrm{B}-3,0}$ & $5,62 \pm 0,05$ & $5,35 \pm 0,02$ & $5,37 \pm 0,06$ \\
$\mathrm{~B}_{\mathrm{J}-1,5}$ & $5,11 \pm 0,02$ & $5,28 \pm 0,12$ & $5,28 \pm 0,05$ \\
$\mathrm{~B}_{\mathrm{J}-3,0}$ & $5,37 \pm 0,13$ & $5,56 \pm 0,06$ & $5,53 \pm 0,03$ \\
\hline
\end{tabular}

nicznego i azotu ogółem w glebie. Chang i in. [2007] wykazali, że zmiany pH gleby mogą być związane ze wzrostem zasobności gleby w składniki mineralne i materię organiczną. W badaniach własnych wyższe $\mathrm{pH}$ zaobserwowano po dodaniu wytłoków jabłkowych do rędziny i buraczanych do gleby bielicowej (tab. 2). Dodatkowo większe zmiany $\mathrm{pH}$ gleby wzbogaconej wytłokami owocowymi i warzywnymi odnotowano dla gleby bielicowej. Wynika to z faktu, że lekka i mniej żyzna gleba jest bardziej przepuszczalna i ma słabsze właściwości buforowe niż rędzina.

\section{Biochemiczna aktywność gleby}

Wprowadzenie środków mineralnych i organicznych do gleby pośrednio determinuje jej aktywność biochemiczną [Santos i in. 2011]. Umożliwiają to mikrobiologiczne procesy enzymatyczne zachodzące w glebie, które poprzez rozkład złożonej materii organicznej dostarczają prostych składników niezbędnych dla rozwoju roślin [Utobo i Tewari 2015].

W badaniach własnych biologiczna aktywność gleby stymulowana była dodatkiem wytłoków owocowo-warzywnych (rys. 1 i 2 ). Wzbogacenie obu gleb materią organiczną w postaci wytłoczyn buraczanych i jabłkowych wywarło pozytywny wpływ na aktywność oddechową i dehydrogenazową (rys. 1 i 2 ). Wzbogacanie gleby w materię organiczną nie zawsze korzystnie wpływa na glebowe procesy mikrobiologiczne. Osady ścieków mleczarskich zaaplikowane do gleby bielicowej negatywnie wpływały na aktywność obecnych w glebie dehydrogenaz [Jezierska-Tys i Frąc 2008].

Wyniki uzyskane w badaniach własnych wykazały, że wprowadzenie dawek $1,5 \%$ i 3,0\% wytłoków buraczanych (rys. 1A i $2 \mathrm{~A}$ ) i jabłkowych (rys. 1B i $2 \mathrm{~B})$ do obu gleb wpłynęło korzystnie zarówno na ilość $\mathrm{CO}_{2}$ wydzielanego z gleby, jak i aktywność dehydrogenaz syntetyzowanych przez mikroorganizmy. 

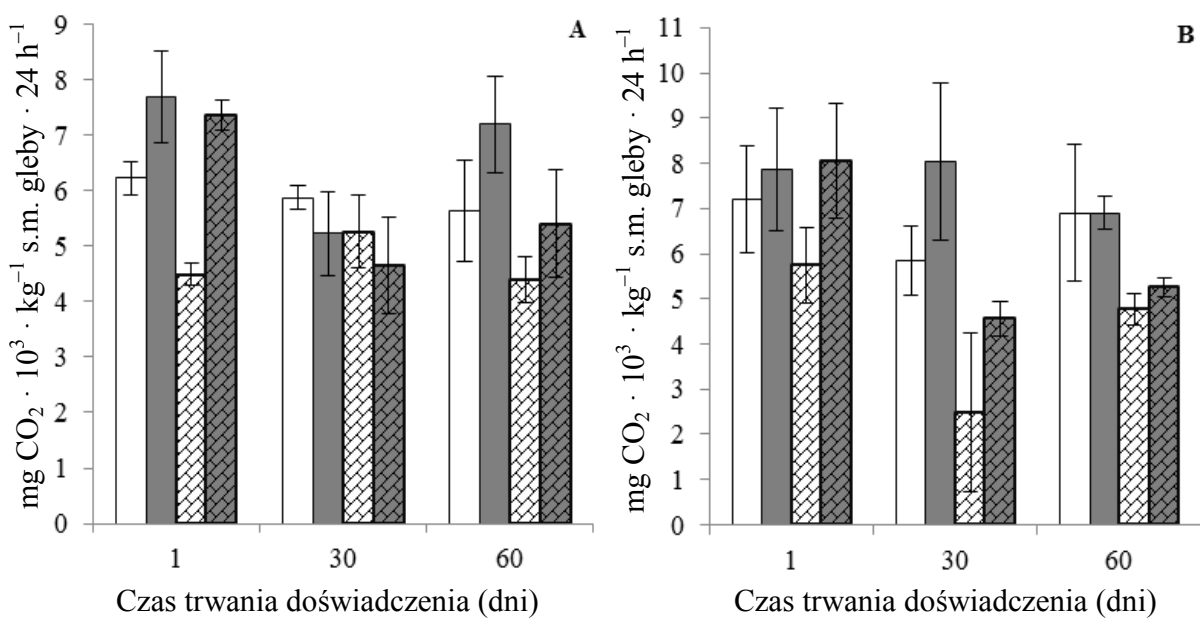

Rys. 1. Aktywność oddechowa w rędzinie i glebie bielicowej wzbogaconej wytłokami buraczanymi (A) i jabłkowymi (B): rędzina z dodatkiem 1,5\% $\bigcirc$ lub 3,0\% $\bigcirc$ wytłoków; gleba bielicowa z dodatkiem 1,5\% $\bigcirc$ lub 3,0\% $\bigcirc$ wytłoków
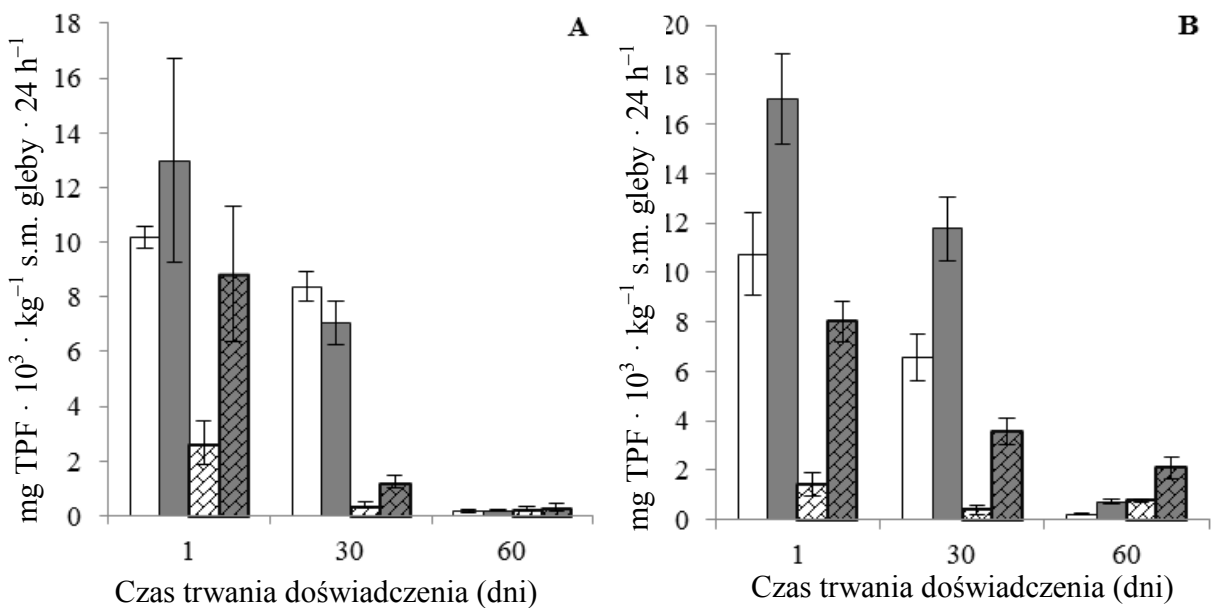

Rys. 2. Aktywność dehydrogenazy w rędzinie i glebie bielicowej wzbogaconej wytłokami buraczanymi (A) i jabłkowymi (B): rędzina z dodatkiem 1,5\% $\bigcirc$ lub 3,0\% $\bigcirc$ wytłoków; gleba bielicowa z dodatkiem 1,5\% $\bigcirc$ lub 3,0\% $\bigcirc$ wytłoków

Było to szczególnie widoczne w przypadku wyższych, tj. 3,0\% dawek wytłoków i świadczyło o dostarczeniu znacznej ilości składników odżywczych niezbędnych do funkcjonowania mikroorganizmów glebowych. Efekt ten wskazuje także na wzrost mikrobiologicznego potencjału oksydo-redukcyjnego gleby warunkowanego aktywnością enzymatyczną. Järvan i in. [2014] wykazali, że materia 
organiczna pochodząca z obornika bydlęcego dodana do gliny piaszczystej (Albeluvisol) najskuteczniej stymulowała aktywność dehydrogenaz. Korzystny wpływ wyższej dawki kompostowanych pozostałości żywności na wydzielanie $\mathrm{CO}_{2} \mathrm{z}$ gleb piaszczystych i gliniastych wykazali Iovieno i in. [2009].

Santos i in. [2011], wprowadzając do gleby osady ścieków garbarskich, wykryli, że niższe dawki odpadów $\left(7,5 \mathrm{Mg} \cdot \mathrm{ha}^{-1}\right)$ skuteczniej niż dawki wyższe $\left(60,0 \mathrm{Mg} \cdot \mathrm{ha}^{-1}\right)$ stymulowały aktywność dehydrogenaz. Wyniki odwrotne uzyskano w toku badań własnych. Wyższą aktywność enzymatyczną odnotowano dla wyższych, tj. 3,0\% dawek wytłoków owocowych i warzywnych, niezależnie od terminu analizy (rys. 1 i 2). Dodatkowo rędzina wykazywała wyższą aktywność oddechową i dehydrogenazową, szczególnie w wariantach $\mathrm{z}$ dodatkiem obu dawek wytłoków jabłkowych (rys. $1 \mathrm{~B}$ i $2 \mathrm{~B}$ ). Ilość wydzielanego z gleby $\mathrm{CO}_{2}$ i jej aktywność enzymatyczna zależą od poziomu związków organicznych, zapewniających energię do wzrostu i funkcjonowania mikroorganizmów. Ich zawartość w rędzinie była wyższa niż w glebie bielicowej.

\section{Liczebność mikroorganizmów glebowych}

Efektywność środka nawozowego i jego wpływ na liczebność drobnoustrojów glebowych zależy od dawki i czasu jego oddziaływania [Chang i in. 2007, Meena i in. 2013]. Największą liczebność bakterii i grzybów, wykorzystując w badaniach własnych odpadową biomasę bogatą w łatwo dostępne frakcje organiczne, odnotowano w rędzinie już w pierwszych godzinach eksperymentu, natomiast $\mathrm{w}$ glebie bielicowej $\mathrm{w}$ dniu 60. (rys. 3 i 4). Ogólna liczebność mikroorganizmów glebowych w rędzinie spadała wraz z czasem trwania doświadczenia. Przyczyną mogło być wykorzystanie większości łatwo dostępnych składników pokarmowych przez mikroorganizmy. Spadek liczebności bakterii w rędzinie był bardziej znaczący po wzbogaceniu gleby dawką 1,5\% wytłoków buraczanych (rys. 3A) i 3,0\% wytłoków jabłkowych (rys. 3B). Ogólna liczebność grzybów w obu glebach była na ogół wyższa dla dawki 3,0\% wytłoków buraczanych (rys. 4A) i jabłkowych (rys. 4B).

Ogólna liczebność bakterii wzrosła $\mathrm{w}$ glebie bielicowej $\mathrm{z}$ dodatkiem 1,5\% wytłoków buraczanych, natomiast spadła po zastosowaniu ich dodatku 3,0\% (rys. 3A). Gleba bielicowa wzbogacona wytłokami jabłkowymi charakteryzowała się zwiększoną liczbą grzybów glebowych w początkowych dniach eksperymentu (rys. 4B). Bardziej znaczący wzrost liczebności tych drobnoustrojów zaobserwowano w przypadku niższego stężenia substratu jabłkowego $(1,5 \%)$ względem wyższej dawki tych wytłoków. Jezierska-Tys i Frąc [2008] wykazały, że liczebność grzybów w glebie płowej wzbogaconej osadem ścieków mleczarskich była stymulowana już w 7., lub dopiero w 60 . dniu trwania badań odpowiednio dla niższych i wyższych dawek osadu. W odniesieniu do liczebności bakterii w glebie płowej cytowane autorki dowiodły, że niższe dawki osadu ścieków mleczarskich skuteczniej oddziaływały na badane drobnoustroje, a ich liczebność spadała wraz z czasem trwania doświadczenia. W świetle wyników badań własnych oraz badań 


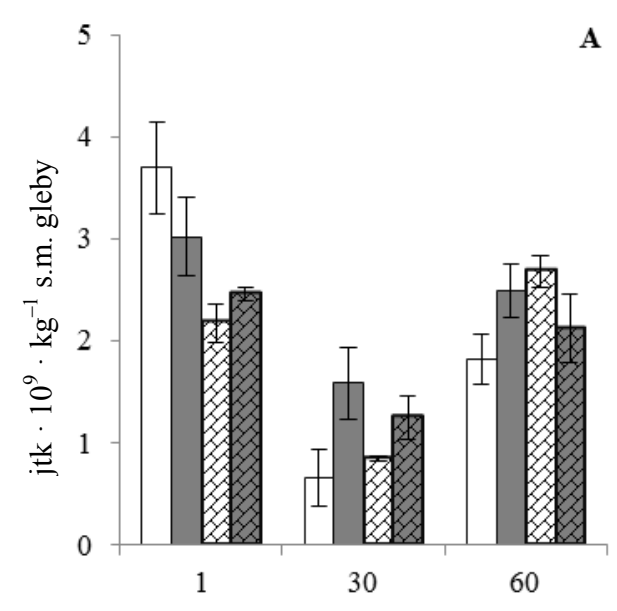

Czas trwania doświadczenia (dni)

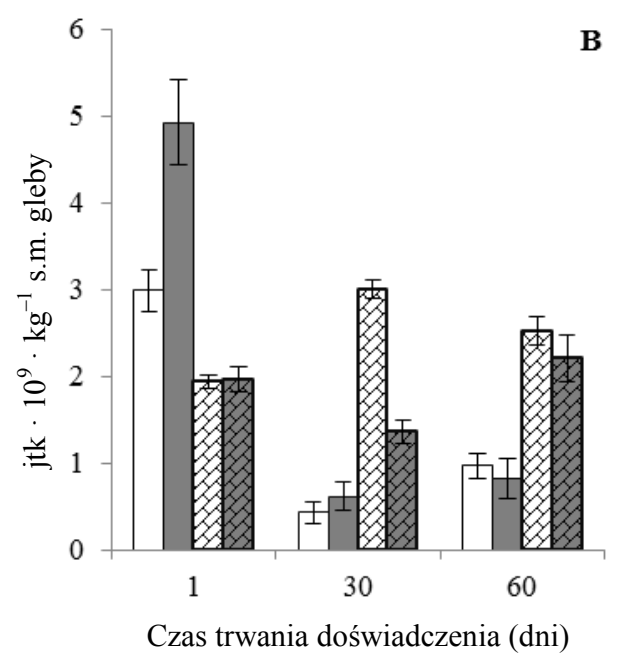

Czas trwania doświadczenia (dni)

Rys. 3. Ogólna liczebność bakterii glebowych w rędzinie i glebie bielicowej wzbogaconej wytłokami buraczanymi (A) i jabłkowymi (B): rędzina z dodatkiem 1,5\% $\bigcirc$ lub 3,0\% $\bigcirc$ wytłoków, gleba bielicowa $\mathrm{z}$ dodatkiem $1,5 \% \bigcirc$ lub $3,0 \% \bigcirc$ wytłoków
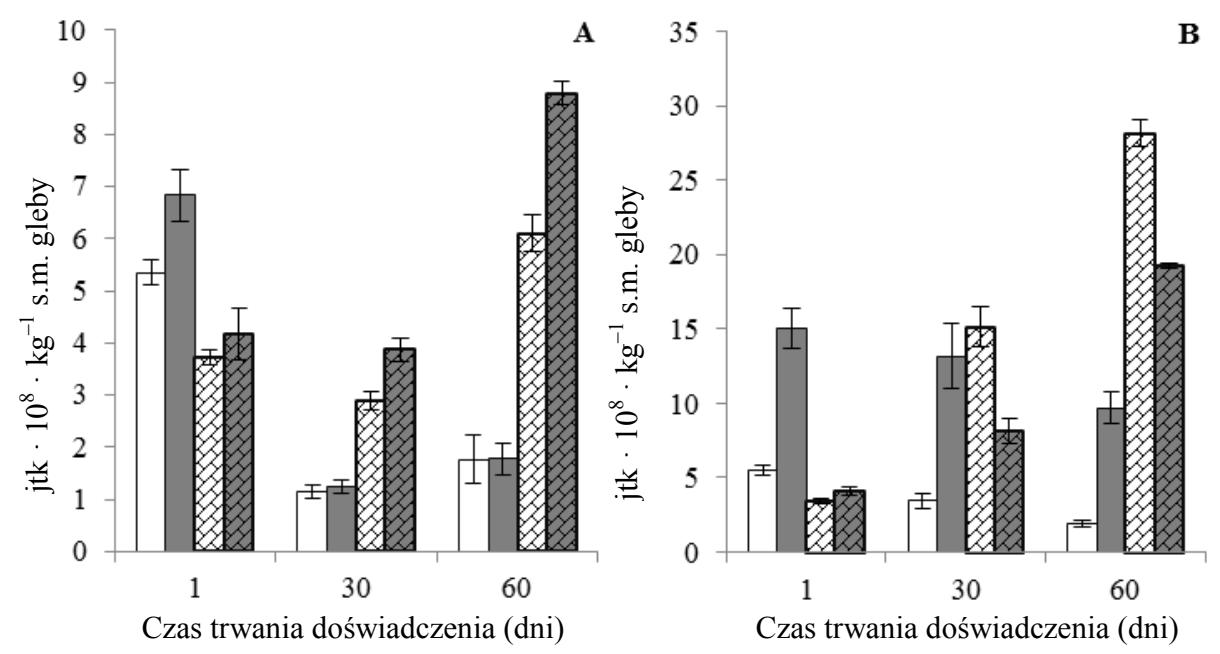

Rys. 4. Ogólna liczebność grzybów glebowych w rędzinie i glebie bielicowej wzbogaconej wytłokami buraczanymi (A) i jabłkowymi (B): rędzina z dodatkiem 1,5\% $\bigcirc$ lub 3,0\% $\bigcirc_{\text {wytłoków, }}$ gleba bielicowa z dodatkiem $1,5 \% \bigcirc$ lub 3,0\% $\bigcirc$ wytłoków 
cytowanych autorów sądzimy, że wpływ dawki wytłoków uzależniony był od właściwości gleby oraz pH środka użyźniającego. Chang i in. [2007] stwierdzili, że dodatek materii organicznej (kompostu) do gleby warunkował jej $\mathrm{pH}$ oraz liczebność obecnych w glebie mikroorganizmów.

\section{Korelacje pomiędzy wskaźnikami biologicznej aktywności gleby}

Badania własne wykazały istotne korelacje pomiędzy badanymi parametrami mikrobiologicznymi i biochemicznymi (tab. 3). Silną ujemną korelację wykazano w glebie bielicowej pomiędzy aktywnością oddechową i pH. Było to uwarunkowane różnymi preferencjami mikroorganizmów glebowych względem $\mathrm{pH}$

Tabela 3. Wartości współczynnika korelacji liniowej r-Pearsona dla wariantów badawczych w rędzinie [R] i glebie bielicowej [B]: R/B

\begin{tabular}{|c|c|c|c|c|c|c|c|}
\hline \multicolumn{2}{|c|}{ Wariant } & Wskaźnik & $\mathrm{P}$ & $\mathrm{R}$ & $\mathrm{D}$ & B & G \\
\hline \multirow{2}{*}{ B } & 1,5 & \multirow{4}{*}{$\mathrm{pH}(\mathrm{P})$} & & & & $1+^{* *}$ & \\
\hline & 3,0 & & & $1+^{*}$ & $1+{ }^{* * *}$ & $1+^{*}$ & \\
\hline \multirow[t]{2}{*}{$\mathrm{J}$} & 1,5 & & & $/^{* *}$ & & $1+^{*}$ & \\
\hline & 3,0 & & & $1-^{* * * *}$ & ${ }^{*}-^{* *}$ & & $+^{*}$ \\
\hline \multirow{2}{*}{ B } & 1,5 & \multirow{4}{*}{$\begin{array}{l}\text { Aktywność } \\
\text { oddechowa } \\
\text { (R) }\end{array}$} & & & & $1^{*}$ & \\
\hline & 3,0 & & $1+^{*}$ & & $1+^{* *}$ & $+{ }^{*} /+^{* *}$ & $-^{* * *}$ \\
\hline \multirow{2}{*}{$\mathrm{J}$} & 1,5 & & $1^{* *}$ & & & $I^{* *}$ & \\
\hline & 3,0 & & $1^{* * *}$ & & $1+^{* * *}$ & & \\
\hline \multirow{2}{*}{ B } & 1,5 & \multirow{4}{*}{$\begin{array}{l}\text { Aktywność } \\
\text { dehydrogenaz } \\
\text { (D) }\end{array}$} & & & & & \\
\hline & 3,0 & & $1+^{* * *}$ & $1+{ }^{* *}$ & & & $+{ }^{* *}$ \\
\hline \multirow{2}{*}{$\mathrm{J}$} & 1,5 & & & & & $+{ }^{*} /-^{* * *}$ & $+^{* * *}$ \\
\hline & 3,0 & & $1^{* *}$ & $1+^{* * *}$ & & $+{ }^{* *}$ & $+^{* * *} /-^{* * *}$ \\
\hline \multirow{2}{*}{ B } & 1,5 & \multirow{4}{*}{$\begin{array}{c}\text { Ogólna } \\
\text { liczebność } \\
\text { bakterii (B) }\end{array}$} & $1+^{* *}$ & $1^{*}$ & & & $++^{* * *} /+^{* * *}$ \\
\hline & 3,0 & & $1+^{*}$ & $++^{*} /+^{* *}$ & & & $+^{* *}$ \\
\hline \multirow{2}{*}{$\mathrm{J}$} & 1,5 & & $1+^{*}$ & $1^{* * *}$ & $+{ }^{*} /-^{* * *}$ & & $+^{* *}$ \\
\hline & 3,0 & & & & $+^{* *}$ & & $+{ }^{*}$ \\
\hline \multirow{2}{*}{ B } & 1,5 & \multirow{4}{*}{$\begin{array}{c}\text { Ogólna } \\
\text { liczebność } \\
\text { grzybów }(\mathrm{G})\end{array}$} & & & & $++^{* * *} /+^{* * * *}$ & \\
\hline & 3,0 & & & $-^{* * * *}$ & $+{ }^{* *}$ & $+{ }^{* *}$ & \\
\hline \multirow[t]{2}{*}{$\mathrm{J}$} & 1,5 & & & & $+^{* * *}$ & $+{ }^{* *}$ & \\
\hline & 3,0 & & $+^{*}$ & & $++^{* * *} /-^{* * *}$ & $+{ }^{*}$ & \\
\hline
\end{tabular}

+/-: korelacja dodatnia/ujemna; ${ }^{*} \alpha=0,1 ; * * \alpha=0,05 ; * * * \alpha=0,01 ; \mathrm{df}=\mathrm{n}-2(7)$

środowiska i skutkowało zróżnicowaniem ilości wydzielonego z gleby $\mathrm{CO}_{2}$. Bakterie, które są producentami $\mathrm{CO}_{2}$, częściej niż grzyby preferują środowiska o odczynie zbliżonym do obojętnego, stąd ich słabsza aktywność oddechowa w glebie bielicowej. Podobną korelację Chang i in. [2007] wykryli pomiędzy aktywnością oddechową a liczebnością bakterii glebowych i Actinobacteria.

Aktywność oddechowa $\mathrm{w}$ glebie bielicowej $\mathrm{z}$ dodatkiem dawki $3,0 \%$ obu rodzajów wytłoków była istotnie skorelowana $\mathrm{z}$ aktywnością dehydrogenaz. Brak 
istotnych korelacji pomiędzy tymi wskaźnikami w rędzinie mógł być uwarunkowany właściwościami tej gleby, w której wprowadzenie wytłoków nie uwidacznia tak znacząco aktywności enzymatycznej jak w innych glebach (tab. 3). Furczak i Joniec [2007] po wprowadzaniu osadów ścieków komunalnych do gleby bielicowej wykazały korelację aktywności dehydrogenaz z aktywnością oddechową, liczebnością oligotrofów, liczebnością bakterii makrotroficznych i grzybów strzępkowych. Parametry biochemiczne związane są z liczebnością mikroorganizmów glebowych odpowiedzialnych za procesy enzymatycznego rozkładu materii organicznej.

$\mathrm{W}$ badaniach własnych odnotowano również dodatnią korelację pomiędzy liczebnością bakterii i grzybów glebowych w rędzinie wzbogaconej wytłokami buraczanymi i jabłkowymi. Najsilniejsze korelacje stwierdzono dla dodatku 1,5\% wytłoków buraczanych, natomiast najsłabsze dla dodatku 3,0\% wytłoków jabłkowych. Zależności takiej nie odnotowano w glebie bielicowej (tab. 3). Dane literaturowe wskazują, że liczebność mikroorganizmów glebowych może być związana z pH gleby [Chang i in. 2007] oraz aktywnością enzymatyczną [Furczak i Joniec 2007].

\section{Wnioski}

Biologiczna aktywność obu badanych gleb uwarunkowana była ich właściwościami oraz rodzajem i dawką zastosowanego środka użyźniającego. Wykazano, że gleby o wyższej zawartości węgla organicznego, np. rędzina, charakteryzowały się większą aktywnością oddechową i dehydrogenazową w stosunku do gleb o niższej zasobności w materię organiczną (gleba bielicowa). Uwarunkowane to było na ogół wyższą dawką substancji organicznej wprowadzonej w postaci wytłoków. Wytłoki jabłkowe korzystniej oddziaływały na ogólną liczebność mikroorganizmów w glebie bielicowej, natomiast wytłoki buraczane w rędzinie. Wprowadzanie do gleby wytłoków buraczanych lub jabłkowych ograniczało liczebność grzybów występujących w rędzinie, stymulowało natomiast ich liczebność w glebie bielicowej. Wzbogacenie obu gleb wyższymi $(3,0 \%)$ dawkami wytłoków owocowych i warzywnych zwiększyło ich $\mathrm{pH}$, w porównaniu $\mathrm{z}$ dawkami niższymi $(1,5 \%)$. Biochemiczne i mikrobiologiczne wskaźniki aktywności gleby były skorelowane ze sobą i uwarunkowane liczebnością oraz metabolizmem mikroorganizmów. Z uzyskanych współczynników korelacji wynika, że efektywniejszymi producentami $\mathrm{CO}_{2} \mathrm{w}$ obu badanych glebach były bakterie, podczas gdy aktywność dehydrogenaz uwarunkowana była liczebnością grzybów.

Podziękowania: Autorzy dziękują Pani dr inż. Justynie Zielińskiej - dyrektorowi handlowemu firmy Kampol-Fruit Sp. z.o.o. w Milejowie - za udostępnienie poprodukcyjnych wytłoków buraczanych i jabłkowych, a także Panu mgr. inż. Dominikowi Cieślakowi oraz Panu mgr. inż. Maciejowi Olkowi za nieocenioną pomoc techniczną podczas wykonywania części doświadczalnej niniejszej pracy. 


\section{Bibliografia}

Angelova V.R., Akova V.I., Artinova N.S., Ivanov K.I., 2013. The effect of organic amendments on soil chemical characteristics. Bulg. J. Agric. Sci. 19(5), 958-971.

Casida L.E., Klein D.A., Santoro T., 1964. Soil dehydrogenase activity. Soil Sci. 98, 371-376.

Chang E., Chung R.S., Tsai Y.H., 2007. Effect of different application rates of organic fertilizer on soil enzyme activity and microbial population. Soil Sci. Plant. Nutr. 53, 132-140. https://doi.org/10.1111/j.1747-0765.2007.00122.x

Furczak J., Joniec J., 2007. Preliminary study of sludge effect on soil microbial activity of a podzolic soil under willow culture. Int. Agrophys. 21, 39-48.

Innangi M., Niro E., D’Ascoli E., Danise T., Proietti P., Nasini L., Regni L., Castaldi S., Fioretto A., 2017. Effects of olive pomace amendment on soil enzyme activities. Appl. Soil Ecol. 119, 242-249. https://doi.org/10.1016/j.apsoil.2017.06.015

Iovieno P., Morra L., Leone A., Pagano L., Alfani A., 2009. Effect of organic and mineral fertilizers on soil respiration and enzyme activities of two Mediterranean horticultural soils. Biol. Fertil. Soils 45, 555-561. https://doi.org/10.1007/s00374-009-0365-z

Järvan M., Edesi L., Adamson A., Võsa T., 2014. Soil microbial communities and dehydrogenase activity depending on farming system. Plant Soil Environ. 60, 459-463. https://doi.org/10.17221/410/2014-PSE

Jezierska-Tys S., Frąc M., 2008. Microbiological indices of soil fertilized with dairy sewage sludge. Int. Agrophys. 22, 215-219.

Korniłłowicz-Kowalska T., Bohacz J., 2005. Wpływ kompostów keratynowo-korowych i keratynowo-koro-słomowych na rozwój bakterii i grzybów w dwóch glebach różniących się systemem uprawy roślin. Zesz. Probl. Post. Nauk. Rol. 506, 245-259.

Kraska P., 2012. Effect of tillage system and catch crop on weed infestation of spring wheat stands (Triticum aestivum L.). Acta Sci. Pol. Agricultura 11, 27-43.

Martin J., 1950. Use of acid, rose Bengal and streptomycin in the plate method for estimating soil fungi. Soil Sci. 69, 215-232.

Meena V.S., Maurya B.R., Verma R., Meena R.S., Jatav G.K., Meena S.K., Meena R., Meena S.K., 2013. Soil microbial population and selected enzyme activities as influenced by concentrate manure and inorganic fertilizer in alluvium soil in Varanasi. Bioscan 8, 931-935.

Pranagal J., Oleszczuk P., Tomaszewska-Krojańska D., Kraska P., Różyło K., 2017. Effect of biochar application on the physical properties of Haplic Podzol. Soil Till. Res. 174, 92-103. https://doi.org/10.1016/j.still.2017.06.007

Puth M.T., Neuhaüser M., Ruxton G.D., 2014. Effective use of Pearson's product-moment correlation coefficient. Anim. Behav. 93, 183-189. https://doi.org/10.1016/j.anbehav.2014.05.003

Rühling Å., Tyler G., 1973. Heavy metal pollution and decomposition of spruce needle litter. Oikos 24, 402-416. https://doi.org/10.2307/3543816

Santos J.A., Nunes L.A.P.L., Melo W.J., Araújo A.S.F., 2011. Tannery sludge compost amendment rate on soil microbial biomass of two different soils. Eur. J. Soil Biol. 47, 146-151. https://doi.org/10.1016/j.ejsobi.2011.01.002

Szwed A., Bohacz J., 2014. Enzymatic activity and certain chemical properties of grey-brown podzolic soil (Haplic Luvisol) amended with compost of tobacco wastes. Arch. Environ. Prot. 40, 61-73. https://doi.org/10.2478/aep-2014-0029

Utobo E.B., Tewari L., 2015. Soil enzymes as bioindicators of soil ecosystem status. Appl. Ecol. Env. Res. 13, 147-169. 
Klaudia Panasiuk ${ }^{1}$, Marlena Księżarczyk ${ }^{2}$, Mikołaj Szczepan², Paulina Leśniak $\mathbb{B}^{3}$, Jose Luis Valverde Piedra $\mathbb{1}^{3}$

\title{
Zalety wykorzystania chromatografii gazowej sprzężonej $\mathrm{z}$ tandemową spektrometrią mas do identyfikacji pestycydów chloroorganicznych
}

\author{
Advantages of using gas chromatography tandem mass spectrometry for identification \\ of organochlorine pesticides
}

\begin{abstract}
Wstęp
Ogólnoświatowa potrzeba wzrostu produkcji żywności wymusza stosowanie środków ochrony roślin (pestycydów) w celu zmniejszenia strat wynikających z niepożądanych oddziaływań organizmów i czynników chorobotwórczych w czasie tego procesu. Jednakże niesie to za sobą ryzyko występowania szkodliwych substancji chemicznych, wchodzących w skład środków ochrony roślin, które mają zdolność do akumulacji w środkach spożywczych oraz $\mathrm{w}$ organizmach żywych, stanowiące kolejne ogniwa łańcucha żywnościowego zwierząt i człowieka. Pomimo ściśle określonych ograniczeń stosowania pestycydów chloroorganicznych (OCP) w rolnictwie wciąż można stwierdzić ich obecność w żywności. Jedna z ważniejszych umów mówiąca o ograniczeniu stosowania pestycydów była Konwencja Sztokholmska podpisana w 2001 roku przez 98 państw, której celem było ograniczenie produkcji i stosowania pestycydów nieulegających degradacji. Dopuszczalna zawartość pestycydów w żywności jest obecnie ściśle określona i ujednolicona przepisami Unii Europejskiej, które obowiązują od 1 września 2008 r. Obowiązujące rozporządzenie obejmuje ponad 1000 substancji chemicznych, których dopuszczalne stężenia wahają się w granicach od 0,01 do $0,05 \mathrm{mg} / \mathrm{kg}$ [Kurdziel i in. 2015]. Mnogość różnorodnych związków chemicznych stosowanych $\mathrm{w}$ rolnictwie stanowi problem w analizie laboratoryjnej. W związku z tym poszukuje się coraz lepszych metod analitycznych do określania stężenia pestycydów w żywności [Góralczyk i in. 2009]. Większość metod analitycznych jest pracochłonna i wymaga znacznych ilości odczynników oraz

\footnotetext{
${ }^{1}$ Uniwersytet Przyrodniczy w Lublinie, Wydział Medycyny Weterynaryjnej, Studenckie Koło Toksykologii Weterynaryjnej, panasiukklaudia@o2.pl

${ }^{2}$ Uniwersytet Przyrodniczy w Lublinie, Wydział Medycyny Weterynaryjnej, Studenckie Koło Toksykologii Weterynaryjnej

${ }^{3}$ Uniwersytet Przyrodniczy w Lublinie, Wydział Medycyny Weterynaryjnej, Zakład Farmakologii, Toksykologii i Ochrony Środowiska
} 
przeprowadzenia kilku etapów przygotowawczych, aby właściwie oddzielić badaną substancję od matrycy [Moret i Conte 2000].

\section{Pestycydy chloroorganiczne}

Termin „pestycydy” obejmuje substancje chemiczne i biologiczne, których celem jest niszczenie bądź opóźnianie rozwoju niepożądanych organizmów. Związki te znalazły zastosowanie głównie w celu ochrony upraw przed szkodnikami, chorobami wywoływanymi przez grzyby, chwastami, zwalczania gryzoni oraz owadów podczas przechowywania żywności, a także w celu ochrony zdrowia człowieka [Witczak i Pohoryło 2016]. Pestycydy chloroorganiczne zaliczane są do trwałych zanieczyszczeń organicznych. Ich właściwości fizykochemiczne odpowiedzialne są za stałą obecność w różnych elementach środowiska, mimo że w większości krajów od wielu lat wprowadzono zakaz lub znaczne ograniczenie ich stosowania [Włodarczyk-Makuła 2015]. Wynika to z faktu, że nadal są one wykorzystywane w krajach tropikalnych, m.in. do zwalczania owadów przenoszących formy inwazyjne pierwotniaków wywołujących malarię [Bouwman 2011]. Silna toksyczność pestycydów chloroorganicznych uwarunkowana jest dobrą rozpuszczalnością w rozpuszczalnikach organicznych i łatwością pokonania barier biologicznych. Ponadto pestycydy te mają zdolność do bioakumulacji w tkance tłuszczowej zwierząt, w związku z czym zauważalny jest charakterystyczny wzrost ich stężenia w kolejnych ogniwach łańcucha pokarmowego. Najbardziej narażone są drapieżniki oraz ludzie, co wynika z ich pozycji w łańcuchu zależności pokarmowych w ekosystemie [Volta $i$ in. 2008]. Najbardziej znanym pestycydem chloroorganicznym jest DDT (dichlorodifenylotrichloroetan), który były stosowany dawniej powszechnie jako środek owadobójczy. Związek ten metabolizowany jest w organizmie zwierząt do DDD (dichlorodifenylodichloroetan) oraz DDE (dichlorodifenylodichloroetylen). W latach 60.-70. XX w., po analizie szkodliwego wpływu tego pestycydu na środowisko, rozpoczęto wycofywanie go z obrotu, ale w związku z jego wysoką skutecznością owadobójczą wciąż stosowany jest w państwach rozwijających się. Dlatego wciąż istnieje możliwość przemieszczania się tych związków w środowisku, gdzie zachowują właściwości toksyczne, gdyż są odporne na działanie czynników atmosferycznych. W związku z tym ważne jest monitorowanie obecności pestycydów w zbiornikach wodnych, gdyż są one także wykrywalne w ich osadach [Zhao i Kee Lee 2001, Tankiewicz i in. 2010].

\section{Cel pracy}

Obecnie kładziony jest coraz większy nacisk na opracowanie skutecznych oraz czułych metod badawczych, dzięki którym możliwa będzie dokładna analiza pozostałości toksycznych związków w żywności pochodzenia roślinnego i zwierzę- 
cego. Metody te powinny charakteryzować się ograniczoną czasochłonnością oraz pracochłonnością, a także zapewniać redukcję używanych w niej surowców w celu obniżenia kosztów wykonania badania. Dlatego celem pracy jest omówienie wykorzystania metody chromatografii gazowej sprzężonej z tandemową spektrometrią mas (GC-MS/MS) do identyfikacji pozostałości pestycydów chloroorganicznych, jak również przedstawienie zalet wykorzystania technik łączonych w powszechnie wykonywanych pracach badawczych. Wykorzystanie sprzężonej chromatografii gazowej ze spektrometrią mas (GC/MS) znacznie zwiększa możliwości identyfikacyjne metody, a dzięki zastosowaniu na przykład trybu monitorowania wybranych jonów (SIM) możliwe jest uzyskanie granic wykrywalności nawet niższych od klasycznych detektorów stosowanych w chromatografii gazowej [Ulanowska i Strączyński 2017]. W niniejszej pracy podjęta została próba ukazania zalet stosowania chromatografii gazowej ze sprzężoną spektrometrią mas, która dostępna jest $\mathrm{w}$ wielu laboratoriach $\mathrm{w}$ celu badania pozostałości pestycydów chloroorganicznych.

\section{Oznaczanie pestycydów}

Metody analityczne wykorzystujące możliwości połączenia chromatografii gazowej (GC - gas chromatography) lub cieczowej (LC - liquid chromatography) ze spektrometrią mas (MS - mass spektrometry) rozwinęły się znacznie w ostatnich dekadach i są dzisiaj metodami referencyjnymi w badaniach monitoringowych oraz w badaniach naukowych. Metody te są bardzo dokładne, lecz wymagają skomplikowanych procedur przygotowawczych, mających na celu izolację określonej substancji (analit) z próbki badanej (matryca) [Moret i Conte 2000]. Mimo znacznych ulepszeń w metodach przygotowania próbek oraz ulepszenia końcowych metod analitycznych oznaczanie pestycydów w środkach spożywczych nie jest łatwe ze względu na dużą różnorodność matryc. Dopiero odpowiednio przygotowana próbka poddaje się analizie końcowej w spektrometrze masowym, który w połączeniu z komputerem umożliwia zbieranie danych o badanych związkach. Identyfikację widm związków przeprowadza się na podstawie wzorców wewnętrznych oraz za pomocą bibliotek o określonym profilu czy grupy związków. Obfitość występujących matryc stanowi jeden z problemów diagnostycznych, gdyż od matrycy zależy dobór prawidłowej techniki badawczej.

Wielkie ułatwienie stanowiło wprowadzenie do metod analitycznych chromatografii gazowej ze spektrometrią mas (GC-MS) oraz chromatografii cieczowej ze spektrometrią mas (LC-MS) w celu poprawienia jakości i szybkości wykonywanych analiz wielu substancji toksycznych, w tym pestycydów i mykotoksyn [Snopczyński i in. 2011]. Na przygotowanie próbek do analizy chromatograficznej składa się kilka etapów. Pierwszym z nich jest pobieranie próbki gazowej, ciekłej lub substancji zaadsorbowanej na powierzchni sorbentu. Do 
próbek dodaje się substancje, które między innymi hamują aktywność biologiczną organizmów znajdujących się w próbkach, eliminują adsorpcję składników próbek na ścianach naczyń czy hamują ulatnianie się składników próbek w celu stabilizacji właściwości i składu próbek. W zależności od rodzaju próbki, możliwe są różne rodzaje obróbki wstępnej. W przypadku próbki stałej jest to np. mielenie, trawienie, rozpuszczenie czy pulweryzacja, w przypadku próbki gazowej jest to adsorpcja lub filtracja, w przypadku próbki ciekłej - rozcieńczenie czy sączenie. Gdy mamy do czynienia z próbką ciekłą + gazową, obróbka wstępna polega na adsorpcji, filtracji lub rozdzieleniu, a kiedy próbka jest stała $\mathrm{z}$ dodatkiem ciekłym lub gazowym, metodami obróbki wstępnej jest sporządzanie ich roztworów [Ragonese i in. 2012].

Następnym etapem przygotowania próbek do analizy chromatograficznej jest ekstrakcja, czyli wyodrębnienie określonych składników z mieszanin stałych lub ciekłych z udziałem selektywnych rozpuszczalników. Derywatyzacja analitu jest następnym etapem przygotowania do analizy końcowej. Jest to przekształcenie analityków w procesie acylowania, alkilowania lub sililowania w bardziej lotne i stabilne termicznie pochodne. Bezpośrednia analiza mieszaniny jest trudna z powodu niskiej czułości i specyficzności oznaczeń, oddziaływaniami między związkami, zbyt niską lotnością i stabilnością termiczną związków [Kozarska i Krzyżewska 2017].

Ostatnim etapem jest rozdział mieszaniny analytów w chromatografie gazowym. Próbka wstrzykiwana jest do ogrzanego portu dozownika, gdzie lotne składniki ulegają odparowaniu i przenoszone są na kolumnę GC w strumieniu gazu nośnego. Dozownikiem stosowanym w chromatografii gazowej jest dozownik typu Split/Splitless (SSI). Kolumny GC mogą być kolumnami analitycznymi lub kapilarnymi. Kolumny analityczne wypełnione są absorbentem, np. krzemionką, tlenkiem glinu czy porowatymi polimerami syntetycznymi, a kolumny kapilarne wypełnione ciekłą fazą stacjonarną, np. skwalenem czy różnego rodzaju silikonami [Ragonese i in. 2012]. Absorbenty są rzadziej stosowanymi fazami stacjonarnymi, ponieważ mają dłuższe czasy retencji i niższą powtarzalność wyników. Stąd ciekła faza stacjonarna jest powszechniej stosowana. Faza powinna charakteryzować się: obojętnością chemiczną, niską lotnością, wysoką stabilnością termiczną oraz wysoką selektywnością względem składników mieszaniny. Najczęściej stosowanymi ciekłymi fazami stacjonarnymi są modyfikowane chemicznie: polisiloksan i jego pochodne oraz glikole polietylenowe (PEG). Rozdzielenie składników w kolumnie GC jest wynikiem różnego tempa migracji spowodowanej różnymi wartościami współczynnika podziału [Wróbel-Jędrzejewska i in. 2012].

Uwolnione związki z GC trafiają do spektrometru masowego, który pełni rolę detektora. Detektor powinien charakteryzować się m.in. szerokim zakresem liniowym odpowiedzi, szerokim zakresem temperaturowym, wysoką czułością, niezawodnością, łatwością, stabilnością i powtarzalnością wskazań, krótkim czasem reakcji i podobieństwem odpowiedzi wobec wszystkich oznaczonych 
substancji. Spektrometr mas (MS) wykazuje uniwersalny rodzaj odpowiedzi, jego granica oznaczalności (LOD - limit of detection - wyrażane $\mathrm{w} \mathrm{g} / \mathrm{s}$ ) wynosi 10 do 12, zakres liniowości zależy od rodzaju analizatora MS, oznaczonych związków i trybu pracy. Za najważniejsze zalety spektrometru mas uznaje się to, że jest on niedesktrukcyjny oraz jest jednym z najdokładniejszych i najskuteczniejszych narzędzi w analizie związków organicznych.

Chromatografia gazowa sprzężona ze spektrometrią mas (GC-MS) jest narzędziem służącym do rozdzielania, identyfikacji oraz ilościowego oznaczania nieznanych substancji. Analizuje lotne związki organiczne w szerokim zakresie stężeń w złożonych matrycach, charakteryzuje się wysoką czułością i selektywnością. GC-MS znalazło wiele różnorodnych zastosowań, chociażby w monitorowaniu środowiska, badaniach petrochemicznych, medycynie, farmacji, czy $\mathrm{w}$ analizie materiału biologicznego [Snopczyński i in. 2011]. W metodzie GC-MS analizowana substancja trafia do jonizatora będącego źródłem jonów, następnie przez analizator do detektora. Najczęściej stosowanymi metodami jonizacji jest jonizacja elektronowa, tzw. twarda jonizacja, oraz jonizacja chemiczna, czyli „miękka” jonizacja. Innymi metodami jonizacji stosowanymi w GC-MS jest jonizacja polem (FI), fotojonizacja (PI), desorpcja plazmą (PD), desorpcja laserowa wspomagana matrycą (MALDI), spektrometria jonów wtórnych (SIMS) i wiele innych [Stolarczyk i Kutner 2009]. Analizator pozwala rozdzielić jony ze względu na stosunek ich masy do ładunku $(\mathrm{m} / \mathrm{z})$. Przykładowymi analizatorami stosowanymi $\mathrm{w}$ chromatografii gazowej sprzężonej ze spektrometrią mas są: kwadrupol (Q), pułapka jonowa (IT), detektor czasu przelotu (TOF), hybrydowe analizatory MS takie jak QqQ, Q/IT, Q/TOF, Orbitrap, sektor magnetyczny (B), czy jonowy rezonans cyklotronowy (ICR). Detektor rejestruje dane analizowanej substancji. Takim detektorem jest puszka Faradaya, powielacz elektronowy, fotopowielacz lub detektor mikrokanalikowy [Stolarczyk i Kutner 2009].

\section{Porównanie metod}

Chromatografia gazowa sprzężona $\mathrm{z}$ tandemową spektrometrią mas (GC-MS/MS) służy do rozdziału stabilnych termicznie i lotnych substancji chemicznych, zaś chromatografia cieczowa sprzężona $\mathrm{z}$ tandemową spektrometrią mas (LC-MS/MS) pozwala na rozdział substancji o wysokiej masie cząsteczkowej oraz takich substancji, które są nielotne. Chromatografia cieczowa obejmuje te metody, w których fazą ruchomą jest ciecz. Ten rodzaj chromatografii wyróżnia wysoka sprawność, duża szybkość procesu, dobra rozdzielczość i stosowanie wysokich ciśnień. Fazę ruchomą pompuje się przez kolumnę chromatograficzną. Pozwala to na identyfikowanie związków, określanie ich zawartości jak również zawartości zanieczyszczeń. Analizowana próbka wstrzykiwana jest na szczyt kolumny, gdzie składniki próbki są rozdzielane. Następnie rozdzielone składniki 
próbki wykrywane są przez detektor. Sygnał z detektora zapisywany jest i przekazywany w postaci cyfrowej. Po przeprowadzonej analizie powstaje chromatogram. Na jego podstawie można rozpoznać związek oraz określić jego zawartość. W przypadku LC-MS/MS zaleca się stosowanie rozpuszczalników o wysokiej czystości, polarności oraz zdolności rozpuszczania wielu różnych związków. Najczęściej stosowanymi rozpuszczalnikami w chromatografii są: acetonitryl, metanol, woda i 2-propanol [Piszcz i in. 2015]. Do przygotowywania buforów zaleca się używać mrówczanu, octanu, wodorowęglanu amonu lub modyfikatorów fazy ruchomej (kwas mrówkowy lub octowy). Modyfikatory stosuje się w celu zwiększenia czułości metody oraz poprawy jonizacji próbki.

\section{Wnioski}

Obie metody analityczne spełniają kryteria zarządzeń Unii Europejskiej, a tym samym charakteryzują się taką samą przydatnością w kwestii wykorzystywania ich $\mathrm{w}$ analizach zawartości pestycydów chloroorganicznych w zróżnicowanym materiale badawczym [Ulanowska i i Strączyński 2012]. GC-MS/MS, w porównaniu do chromatografii cieczowej sprzężonej z tandemową spektrometrią mas (LC-MS/MS) służy do rozdziału lotnych i stabilnych termicznie związków chemicznych, zaś LC-MS/MS służy do rozdziału substancji nielotnych oraz o wysokiej masie cząsteczkowej. Możliwość wykorzystywania małych próbek, a tym samym wysoka dokładność chromatografii gazowej sprzężonej ze spektrometrią mas stanowią o niezaprzeczalnej wyższość tej metody nad chromatografią cieczową $\mathrm{w}$ analizie próbek w kierunku zawartości pestycydów chloroorganicznych [Fornal $\mathrm{i}$ in. 2013].

\section{Bibliografia}

Bouwman H., Van den Berg H., Kylin H., 2011. DDT and Malaria Prevention: Addressing the Paradox. EHP 119(6), 744-747. https://doi.org/10.1289/ehp.1002127

Fornal E., Stachniuk A., Mroczka R., Chrzanowska A., Zięba E. (red.), 2013. Zastosowanie tandemowej spektrometrii mas sprzężonej z chromatografią cieczową w kontroli jakości żywności. LAB 18(2), 6-9.

Góralczyk K., Struciński P., Hernik A., Czaja K., Korcz W., Ludwicki J.K., 2009. Badanie pozostałości pestycydów w żywności pochodzenia roślinnego w Polsce w latach 2004-2007. Rocz. Panstw. Zakł. Hig. 60(2), 113-119.

Kozarska A., Krzyżewska I., 2017. Chromatograficzne metody oznaczania parabenów w próbkach środowiskowych i kosmetykach (cz. II). LAB. 22(2), 6-12.

Kurdziel A., Szpyrka E., Słowik-Borowiec M., Podbielska M., Matyaszek A., Rupar J., 2015. Porównanie technik ekstrakcji i oczyszczania w oznaczaniu pozostałości pestycydów. Prog. Plant Prot. 55(2), 141-146. http://dx.doi.org/10.14199/ppp-2015-023

Moret S., Conte L.S., 2000. Polycyclic aromatic hydrocarbons in edible fats and oils: occurrence and analytical methods. J. Chromatogr. A 882(1-2), 245-253. https://doi.org/10.1016/S00219673(00)00079-0 
Piszcz P., Tomaszewska M., Głód B.K., 2015. O możliwości zastosowania chromatografii cienkowarstwowej do oznaczania całkowitego potencjału antyoksydacyjnego. Część I. Dobór warunków chromatograficznych. Camera Separatoria 7(1), 41-51.

Ragonese C., Sciarrone D., Tranchida P.Q., Dugo P., Mondello L., 2012. Use of ionic liquids as stationary phases in hyphenated gas chromatography techniques. J. Chromatogr. A 1255, 130-144. https://doi.org/10.1016/j.chroma.2012.04.069

Snopczyński T., Struciński P., Góralczyk K., Czaja K., Hernik A., Korcz W., Kucharska A., Ludwicki J.K., 2011. Zastosowanie metody QuEChERS w połączeniu z chromatografią gazową $\mathrm{z}$ detektorem wychwytu elektronów (GC-ECD) w analizie pozostałości pestycydów w żywności. Rocz. Panstw. Zakł. Hig. 62(2), 145-151.

Stolarczyk E.U., Kutner A., 2009. Zastosowanie spektrometrii mas w analizie farmaceutycznej zanieczyszczeń organicznych. Farm. Pol. 65(8), 586-593.

Tankiewicz M., Fenik J., Biziuk M., 2010. Determination of organophosphorus and organonitrogen pesticides in water samples. TrAC 29(9), 1050-1063. https://doi.org/10.1016/j.trac.2010.05.008

Ulanowska A., Strączyński G., 2012. Nowe perspektywy w analizie żywności. LAB 17(4), 31-34.

Volta P., Tremolada P., Neri M.C., Giussani G., Galassi S., 2008. Age-Dependent Bioaccumulation of Organochlorine Compounds in Fish and their Selective Biotransformation in Top Predators from Lake Maggiore. Water, Air Soil Pollut. 197, 193-209. https://doi.org/10.1007/s11270-008-9803-z

Witczak A., Pohoryło A., 2016. Ocena zanieczyszczenia żywności pestycydami fosforoorganicznymi a ryzyko zdrowotne konsumentów. Kosmos 4(313), 503-512.

Włodarczyk-Makuła M., 2015. Kumulacja WWA i związków chloroorganicznych w wodach powierzchniowych. LAB 20(6), 28-34.

Wróbel-Jędrzejewska M., Sender W., Kuleta P., Stęplewska U., 2012. Analiza syntetycznych czynników chłodniczych metodą chromatograficzną. Część 1 - Przegląd aparatury chromatograficznej. Post. Nauki i Technol. Przem. Rol. Spoż. 67(3), 100-114.

Zhao L., Kee Lee H., 2001. Application of static liquid-phase microextraction to the analysis of organochlorine pesticides in water. J. Chromatogr. A 919(2), 381-388. https://doi.org/10.1016/S0021-9673(01)00816-0 


\author{
Paweł Szabat ${ }^{1}$, Bartłomiej Sulima ${ }^{2}$, Maria Zielińska ${ }^{2}$, Jan Podolski ${ }^{2}$, \\ Szymon Chmielewski ${ }^{3}$
}

\title{
Smartfon vs LiDAR - pomiar wybranych cech struktury drzewostanu miejskiego metodą citizen science
}

\author{
Smartfon vs LiDAR - measurement of selected features of urban tree stand structure by means \\ of citizen science method
}

\begin{abstract}
Wstęp
Rozwój technologii informacyjno-komunikacyjnych (ang. IcT) sprawia, że smartfon, jako urządzenie wyposażone w różne sensory (np. akcelerometr, żyroskop, magnetometr), może pełnić rolę urządzenia pomiarowego. Stały dostęp do Internetu ery Web 2.0 [Sieber i in. 2016] umożliwia przesyłanie danych pomiarowych $\mathrm{w}$ trybie rzeczywistym, a smartfon, stanowiący część tzw. Internetu Rzeczy (ang. IoT) [Gul 2018], strumieniuje niezliczone ilości danych, głównie wynikające $\mathrm{z}$ interakcji społecznych, w jakich uczestniczy jego użytkownik. Coraz częściej są to również dane pomiarowe o charakterze naukowym, wytwarzane w ramach nauki obywatelskiej (ang. Citizen Science) [Haklay 2013]. Zastosowania profesjonalne wymagają, aby urządzenie pomiarowe cechowało się określoną precyzją i czułością, a wykonany nim pomiar pozwalał na uzyskanie dokładnych i wiarygodnych danych. Smartfon, dzięki sensorom pomiarowym i dedykowanej do ich obsługi aplikacji mobilnej, może pełnić funkcję narzędzia pomiarowego, ale dokładność i precyzja pomiarów muszą być zweryfikowane, tak by móc określić zakres zastosowań oraz poziom wiarygodności w ten sposób wykonanych pomiarów. Mnogość aplikacji korzystających z danych rejestrowanych przez sensory smartfonów pozwala zadać pytanie dotyczące wiarygodności i ogólnej użyteczności pomiarów wykonywanych smartfonem. Starając się odpowiedzieć na to pytanie, w prezentowanej pracy podjęto eksperyment pomiarowy oparty na porównaniu pomiarów wykonywanych smartfonem oraz profesjonalnymi instrumentami pomiarowymi. Tematycznie eksperyment osadzony jest $\mathrm{w}$ dziedzinie nauk rolniczych (nauki leśne) i czerpie $\mathrm{z}$ szerokiego spektrum

\footnotetext{
${ }^{1}$ Uniwersytet Przyrodniczy w Lublinie, Wydział Agrobioinżynierii, Studenckie Koło Naukowe Leśników, szabatpawe119@gmail.com

${ }^{2}$ Uniwersytet Przyrodniczy w Lublinie, Wydział Agrobioinżynierii, Studenckie Koło Naukowe Leśników

${ }^{3}$ Uniwersytet Przyrodniczy w Lublinie, Katedra Łąkarstwa i Kształtowania Krajobrazu, Zakład Studiów Krajobrazowych i Gospodarki Przestrzennej, szymon.chmielewski@up.lublin.pl
} 
metod geoinformacyjnych, w tym teledetekcyjnych i geomatyki. W kontekście tzw. neogeografii [Giętkowski 2013], rozumianej jako zasób wiedzy, umiejętności w pełni umożliwiających powszechne, codzienne korzystanie z informacji przestrzennej i narzędzi geoinformacyjnych, funkcjonuje Citizen Science (CS), czyli nauka metodą obywatelską. CS to metoda badań naukowych angażująca społeczeństwo do udziału w procesie naukowym. W zależności od poziomu zaangażowania naukowców amatorów Haklay [2013] wyróżnia cztery możliwe poziomy partycypacji: (1) zbieranie danych, (2) zbieranie i interpretowanie danych, (3) propozycje pytań badawczych, (4) formułowanie problemów badawczych. Uczestnicy projektów CS za pomocą aplikacji mobilnych w smartfonie lub aplikacji webowych zbierają, analizują i udostępniają swoje dane obserwacyjne, tworząc otwarte repozytoria danych. Przykładami projektów, w których dane zebrane przez naukowców amatorów, wolontariuszy służą rozwojowi badań naukowych, mogą być: eBird [Roick i in. 2016], iNaturalist, Bee Watch [Luna i in. 2018] oraz projekt GLOBE Observer, którego dotyczy opisywany eksperyment badawczy. Program GLOBE Observer został uruchomiony przez Amerykańską Agencję Kosmiczną (NASA), składa się z kilku tematycznych modułów, jednym $z$ nich jest projekt GLOBETrees. Jego głównym celem badawczym jest walidacja pomiarów wysokościowych wykonywanych techniką skanowania laserowego (LiDAR) przez satelitę ICESat-2. Satelita mierzy przede wszystkim wysokość pokrywy lodowców, ale wcześniej jego pomiary muszą być zwalidowane, jednym z punktów odniesienia będzie tu wysokość drzew. Stąd też pomysł naukowców NASA na udostepnienie aplikacji CS - GLOBETrees, za pomocą której użytkownicy z całego świata mogą mierzyć wysokość drzew i udostępniać te dane naukowcom celem przeprowadzenia walidacji satelity. Jednak metoda CS bywa krytykowana jako mało dokładna, amatorska i dostarczająca danych o niskiej jakości [Sheppard i Terveen 2011], których zastosowanie $\mathrm{w}$ badaniach naukowych jest ograniczone. Podejmowany w pracy eksperyment pomiarowy ma na celu sprawdzenie, na ile te krytyczne głosy są uzasadnione. Wyniki eksperymentu pozwolą określić ograniczenia metody CS i zdefiniować warunki pomiarowe, w których zbierane dane obarczone są dużym błędem pomiarowym.

\section{Pomiar struktury wysokościowej drzewostanu z pułapu lotniczego}

Wysokość drzew jest podstawową cechą taksacyjną rejestrowaną podczas prac z zakresu inwentaryzacji lasu, kluczową do określania zasobności drzewostanów. Przed wprowadzeniem rozwiązań geoinformacyjnych pomiar wysokości wszystkich drzew w drzewostanie był niemożliwy do przeprowadzenia ze względu na czasochłonność i stosowaną metodykę prac inwentaryzacyjnych [Wężyk i Solecki 2008]. W zależności od potrzeb inwentaryzacyjnych pomiar wysokości może być wykonany bezpośrednio $\mathrm{w}$ terenie lub z zastosowaniem teledetekcji satelitarnej lub lotniczej. LiDAR, dzięki penetracji wiązką lasera pionowej struktury drzewostanu, pozwala uzyskać trójwymiarową chmurę punktów, na podstawie której metodami geoinformacyjnymi określa się podstawowe 
miary struktury drzewostanu: zwarcie i wielkość koron, wysokość i zagęszczenie drzew z milimetrową dokładnością. LiDAR lotniczy (ang. Airborne Laser Scanning, ALS) to aktywny system teledetekcyjny polegający na rejestracji promieni odbitych od powierzchni terenu i koron drzew z użyciem wiązki promieni światła (lasera) wysyłanego z pułapu lotniczego (300-800 m), włączając w to bezzałogowe statki latające (ang. Unmanned Aerial Vehicle, UAV) [Okła i in. 2013]. Procedura określania wysokości koron drzew, na podstawie danych LiDAR-ALS obejmuje: a) klasyfikację chmury punktów i wydzielenie klasy wegetacji wysokiej (klasa 5.) oraz klasy gruntu (klasa 2.); b) normalizację chmury punktów celem przeliczania współrzędnej wysokości (z) względem gruntu; c) segmentację koron drzew (2D lub 3D); d) wyznaczenie lokalnych maksimów wysokości w obrębie segmentów, tzw. CHM (ang. Conopy Height Model). Wysokościowy model koron drzew (ang. Conopy Height Model, CHM) powstaje przez odjęcie wartości odpowiadających sobie pikseli w numerycznym modelu pokrycia terenu (ang. Digital Surface Model, DSM) i numerycznym modelu terenu (ang. Digital Terrain Model) w obszarze leśnym [Stereńczak i in. 2009]. CHM przydaje się przy określaniu takich parametrów drzewostanów jak: wysokość, zasięg koron, liczba drzew, średnica i zwarcie koron. Ze względu na wysoką dokładność i potwierdzoną precyzję pomiarów LiDAR-ALS model ten można przyjąć jako referencję do pomiarów wysokości drzew wykonywanych innymi technikami.

\section{Pomiar struktury wysokościowej drzewostanu z pulapu naziemnego}

Techniki naziemne polegają na naziemnym skanowaniu całego obszaru badawczego (ang. Terrestial Laser Scanning, TLS) lub pomiarze pojedynczych obiektów - drzew. W tym celu najczęściej stosowane są dalmierze laserowe. W opisywanym eksperymencie użyto lunetowego dalmierza laserowego TruPulse 360 firmy Laser Technology. Jest to instrument pomiarowy w postaci lunetki $\mathrm{z}$ wbudowanym bezlustrowym dalmierzem laserowym, inklinometrem i kompasem. Pomiar odległości do obiektu odbywa się przez wycelowanie w obiekt lunetką (najpierw w punkt horyzontalny, następnie w podstawę oraz wierzchołek), a wynik pomiaru odczytuje się na wbudowanym wyświetlaczu LCD (rys. 1). Dokładność pomiaru odległości do bliskich celów w korzystnych warunkach wynosi $30 \mathrm{~cm}$.

W leśnych pracach inwentaryzacyjnych zastosowanie znajdują również dalmierze analogowe (tzw. przechyłomierz). Zaletą jest całkowita niezależność tego instrumentu pomiarowego od zasilania, wadą - stosunkowo żmudna procedura pomiarowa. Pomiar następuje poprzez odczytanie wysokości wierzchołka oraz odziomka drzewa. Jednak, aby odczyt był dokładny, należy rozciągnąć taśmę, odmierzając 15 lub 20 metrów w zależności od wysokości drzewa. Opisane powyżej metody z różną dokładnością i precyzją pozwalają stworzyć wysokościowy model koron drzew. Dokładność pomiaru określa się jako zbieżność zachodzącą pomiędzy wartością wielkości zmierzoną, a tą, która ma być zmierzona. Precyzja pomiaru to zbieżność, która zachodzi pomiędzy wartościami wielkości 

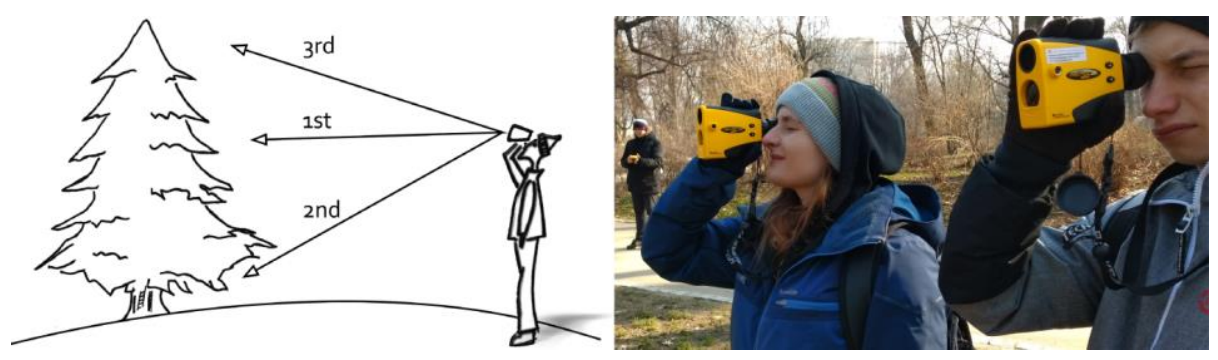

Rys. 1. Metoda pomiaru wysokości drzewa lunetowym dalmierzem laserowym wyposażonym w żyrokompas (a) testowana podczas studenckiej kampanii pomiarowej w lubelskim Ogrodzie Saskim (b); grafika. M. Zielińska, fot. S. Chmielewski

otrzymanymi przy powtarzalności pomiarów, zmierzonymi na tych samych lub podobnych obiektach $\mathrm{w}$ określonych warunkach. Czułość przyrządu pomiarowego to najmniejsza zmiana wartości, którą może zarejestrować dany przyrząd pomiarowy [Płochocki 1996]. Dokładność pomiaru wysokości drzew za pomocą aplikacji GLOBETrees nie była dotąd badana eksperymentalnie, a zaproponowany przez autorów tok postępowania metodycznego pozwala również wnioskować na temat przydatności tego typu rozwiązań do celów naukowych oraz aktywności w ramach nauki obywatelskiej.

\section{Metoda}

\section{Obszar badań}

Eksperyment przeprowadzono w Ogrodzie Saskim w Lublinie. Do badania wybrano 100 drzew o pełnym rozwoju budowy zewnętrznej. Losowo wybrano następujące gatunki: sosnę zwyczajną (Pinus sylvestris), świerk pospolity (Picea abies), topolę białą (Populus alba), dąb szypułkowy (Quercus robur), lipę drobnolistną (Tilia cordata), klon (Acer platanoides), grab pospolity (Carpinus betulus).

\section{Modele referencyjne}

W eksperymencie badawczym walidację metody Citizen Science wykonano w odniesieniu do trzech modeli referencyjnych:

CHM - model wysokościowy koron drzew (ang. conopy height model; CHM), $\mathrm{GT}_{1}$ - pierwszy model typu ground truth (GT1) oraz model uzupełniający GT2 - drugi model typu ground truth uzyskany na podstawie pomiarów wykonanych za pomocą ręcznego przechyłomierza CHM przygotowano na podstawie chmury punktów 3D pozyskanej techniką LiDAR-ALS w 2015 r. i udostępnionych na potrzeby badawcze przez Urząd Miasta Lublin. Średnia gęstość chmury punktów analizowanego obszaru badań wynosiła $17 \mathrm{pkt} / \mathrm{m}^{2}$, dane sklasyfikowano zgodnie ze standardem LAS 1.2. Utworzono podzbiór danych, skła- 
dający się z klasy 5. oraz 2. i przeprowadzono normalizację chmury punktów 3D celem obliczenia wysokości drzew względem powierzchni gruntu. Następnie chmurę punktów poddano segmentacji w oprogramowaniu eCognition Developer algorytmem segmentacji wielopoziomowej [Baatz $i$ in. 2000]. Ze zbioru wybrano 100 segmentów odpowiadających koronom drzew wyselekcjonowanych do pomiaru wysokości w ramach prowadzonego eksperymentu. Selekcję wykonywano manualnie, na podstawie wzrokowej interpretacji ortofotomapy oraz danych pomiarowych lokalizacji drzew, uzyskanych za pomocą odbiornika GNSS w trybie RTK (dokładność pozycyjna nie gorsza niż $20 \mathrm{~cm}$, pomiar $\mathrm{z}$ uśrednieniem 20 epok). W obrębie segmentów wykonano analizę Local Maxima i na tej podstawie oszacowano wysokość drzewa. Tak przygotowany CHM poddano wizualizacji w oprogramowaniu ArcGIS Pro.

Model GT1 przygotowano na podstawie pomiarów wysokości drzew, wykonanych dalmierzem laserowym Trimble TruPulse 360B. Pomiar wykonano za pomocą dwóch urządzeń udostępnionych przez Zakład Studiów Krajobrazowych i Gospodarki Przestrzennej Uniwersytetu Przyrodniczego w Lublinie. Pomiary wykonało dwóch niezależnych operatorów. Dane pomiarowe zapisano w arkuszu kalkulacyjnym i poddano wizualizacji w oprogramowaniu ArcGIS Pro.

Model GT2. Metodyka pomiaru przechyłomierzem Suunto PM-5 oparta jest na zasadzie trygonometrycznej. Patrząc przez wizjer, należy go skierować na badane drzewo. Dzięki iluzji optycznej obiekt badany i pozioma linia pokrywają się, pokazując skalę wysokości umieszczoną na walcu. W tym momencie należy skierować wizjer do góry, aż do czubka drzewa i zapamiętać wskazaną wartość po lewej stronie skali. Kolejnym krokiem jest wycelowanie przechyłomierza w dół, na podstawę drzewa, i zapamiętanie znaków „,+" lub „,-" oraz wartości, jaką wskazuje skala.

Na podstawie zgromadzonych wyników, należy wykonać działanie odejmowania wartości pierwszej (czubek drzewa) od drugiej (podstawa), z uwzględnieniem ,," i ,-", wynik równania wyznacza wysokość drzewa w metrach. Tryb ten wymaga, aby osoba mierząca znajdowała się w odległości $20 \mathrm{~m}$ od drzewa, odległość tę każdorazowo odmierzano taśmą mierniczą. Pomiary wykonało dwóch niezależnych operatorów. Dane zapisano w przygotowanej tabeli, którą przepisano do arkusza kalkulacyjnego.

\section{Pomiar wysokości drzew aplikacją Citizen Science i porównanie z modelem referencyjnym}

Pomiary wykonywane były przez czterech niezależnych operatorów, którzy na swoich smartfonach (Huawei - P10, P30 Pro, Mate 10 Pro oraz Mate 10 Lite) zainstalowali aplikację GLOBE Observer. Użytkownicy indywidualnie kalibrowali aplikację w odniesieniu do swojego wzrostu i długości kroku. Na wynik pomiaru składają się poszczególne elementy: odległość od drzewa mierzona w krokach oraz kąt, pod jakim odchylono urządzenie podczas kierowania obiektywu smartfona na czubek oraz podstawę drzewa. Odczyty z żyroskopu smartfona zapisywane są automatycznie przez aplikację, liczbę kroków „do drzewa” wprowadza użytkownik, na- 
stępnie aplikacja samodzielnie przelicza zebrane składowe pomiaru na wysokość drzewa. Każde drzewo mierzone było niezależnie przez wszystkich operatorów, wyniki pomiarów zapisano w arkuszu kalkulacyjnym i podano jako średnią arytmetyczną czterech pomiarów. Ocenę dokładności pomiaru przeprowadzono na podstawie wartości błędu względnego oraz odchylenia standardowego.

\section{Wyniki}

\section{Model referencyjny CHM}

W wyniku geoprzetwarzania danych LiDAR-ALS uzyskano chmurę liczącą 6970842 punkty, w tym do klasy 2. (grunt) należało 2337359 punktów (33,53\%), do klasy 5. (wysoka wegetacja) 2451176 punktów (35,16\%). Minimalna wysokość w obrębie klasy wysokiej wegetacji wynosiła 184,01 m n.p.m., maksymalna 244,69 m n.p.m. Normalizację chmury punktów przeprowadzono $\mathrm{z}$ odcięciem wartości poniżej $5 \mathrm{~m}$ nad poziom gruntu, celem wyeliminowania drzew niskich, niebiorących udziału w eksperymencie badawczym, uzyskana maksymalna wartość wysokości w obrębie klasy 5 . wyniosła $37,80 \mathrm{~m}$ nad poziom gruntu i wartość tę uznano za wysokość najwyższego drzewa w Ogrodzie Saskim wg CHM. W wyniku segmentacji uzyskano 1572 segmentów. Minimalna powierzchnia segmentu wynosiła $5,9 \mathrm{~m}^{2}$, największy segment miał powierzchnię $506,6 \mathrm{~m}^{2}$, średnia powierzchnia wszystkich wygenerowanych segmentów wynosiła $70,1 \mathrm{~m}^{2}$, mediana powierzchni $58 \mathrm{~m}^{2}$, odchylenie standardowe 53,35. Przygotowany zgodnie $\mathrm{z}$ opisem metodycznym CHM przedstawiono $\mathrm{w}$ postaci geowizualizacji (rys. 2). Przykładowe wysokości drzew odczytane z modelu CHM

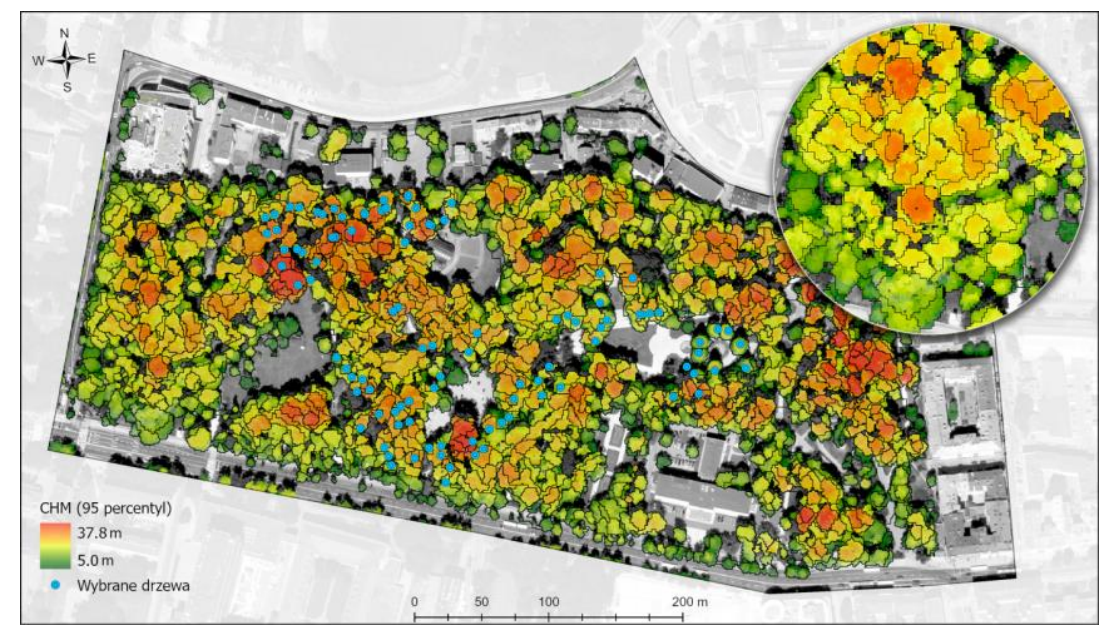

Rys. 2. Wysokościowy model koron drzew (CHM) wraz z wygenerowanymi segmentami; na powiększeniu przedstawiono południowo-wschodnią część, w której osiągnięto wysoką poprawność segmentacji 
Tabela 1. Przykładowe dane pomiarowe dotyczące wysokości drzew

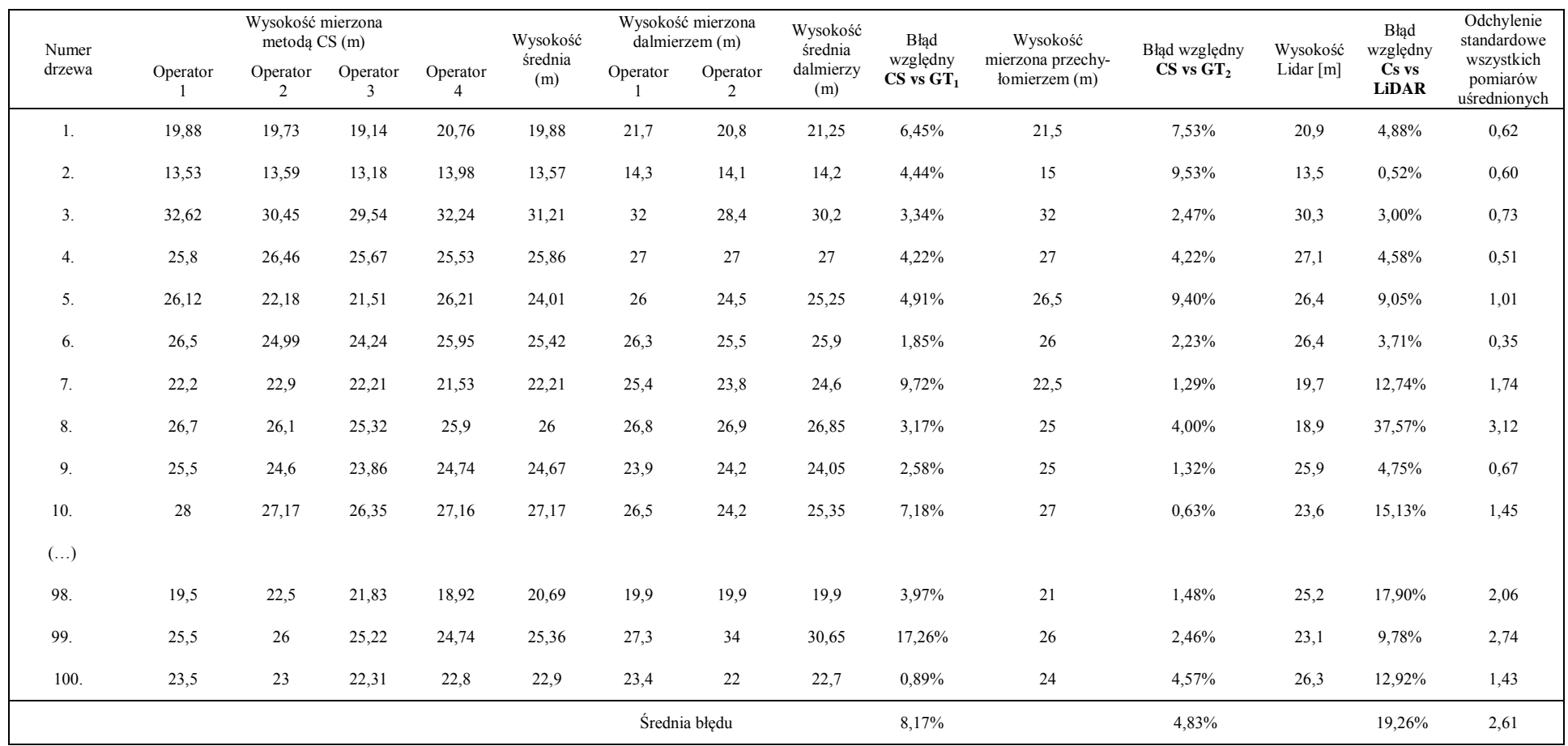


zestawiono w tabeli 1, ze względu na objętość tabeli nie jest ona prezentowana w całości. Dla 100 analizowanych drzew minimalna wysokość odczytana z modelu CHM wynosiła 10,3 m, wysokość najwyższego drzewa wyniosła 37,1 m, średnia wysokość wynosiła 27,4 m. Zgodnie z modelem CHM spośród 100 wybranych do eksperymentu drzew 26 były okazami o wysokości powyżej $30 \mathrm{~m}$.

\section{Wyniki pomiarów dalmierzem - model GT $_{1}$ i GT $_{2}$}

Zaplanowane sesje pomiarów terenowych trwały $3,5 \mathrm{~h}$ oraz $7 \mathrm{~h}$, odpowiednio dla pomiarów wykonywanych dalmierzem TruPulse 360B oraz przechyłomierzem. Prawie dwukrotna różnica w czasie wynika $\mathrm{z}$ konieczności dodatkowego pomiaru odległości „od drzewa”, jaki jest niezbędny do wyliczenia wysokości obiektu mierzonego za pomocą przechyłomierza. Ponadto osoba wykonująca pomiar musi samodzielnie obliczyć wysokość na podstawie prostego równania, co nie tyle wpływa na wydłużenie czasu niezbędnego na dokonanie pomiaru, ale może być również źródłem błędów. Zaobserwowano także, iż wynik pomiaru podawany jest przez operatora bez części dziesiętnych, w opisywanym eksperymencie taka sytuacja dotyczyła ponad połowy (53\%) pomiarów. Odchylenie standardowe pomiędzy modelem GT1 i GT2 oscyluje od 0,03 do 6,45 i tylko w trzech przypadkach uzyskany wynik dla GT1 i GT2 był identyczny, natomiast w 59\% miał wartość niższą niż 1 . Główną zaletą modelu GT1 jest dwukrotnie krótszy czas pozyskania danych pomiarowych i wysoka precyzja (w 34\% wykonanych pomiarów różnica pomiędzy pomiarem wysokości wykonanym przez dwóch niezależnych operatorów nie przekraczała $1 \mathrm{~m}$ ).

\section{Wyniki pomiarów aplikacją Citizen Science}

Sesja pomiarowa wykonana za pomocą aplikacji Citizen Science trwała $1 \mathrm{~h}$ i pomimo że pomiar był wykonywany przez 4 niezależnych operatorów (w przypadku GT1 i GT2 było ich dwóch), tę metodę pomiarową można uznać za najszybszą i najbardziej dostępną. Wartości odchylenia standardowego dla czterech wykonanych pomiarów wysokości tego samego drzewa wahają się od 0,22 do 2,17 , przy czym w przypadku $81 \%$ pomiarów odchylenie standardowe nie przekracza wartości 1. Świadczy to o dużej precyzji pomiarowej aplikacji, na którą nie ma wpływu model lub producent smartfona, wszystkie używane do pomiarów smartfony należą do tego samego segmentu technologicznego i zbliżonej konfiguracji systemowej. Porównanie $\mathrm{z}$ modelami referencyjnymi potwierdza wysoką dokładność uzyskiwanych pomiarów. Najmniejsze różnice stwierdzono w porównaniu pomiarów metodą Citizen Science i pomiarów w modelu GT2, średnia wartość błędu względnego obliczonego na podstawie 100 pomiarów wyniosła 4,38\%. Porównanie z modelem GT1 okazuje się być bardziej krytyczne, w tym przypadku średnia wartość błędu wyniosła $8,15 \%$. W wyniku walidacji pomiarów względem CHM stwierdzono błąd względny, wynoszący 19,30\%, co może być podstawą do dalszej dyskusji na temat dokładności metody Citizen Science. 


\section{Podsumowanie i wnioski}

W pracy podjęto próbę oceny dokładności pomiarów wysokości drzew za pomocą ogólnodostępnej aplikacji na smartfony - GLOBETrees. W prezentowanym doświadczeniu, na podstawie walidacji względem dwóch modeli referencyjnych, wykazano, iż oceniana tu metoda CS cechuje się niższą dokładnością pomiarową, ale ze względu na stosunkowo niewielkie różnice względem pomiarów referencyjnych (średni błąd nie większy niż 20\%) można ją stosować jako metodę odpowiednią dla naukowców amatorów. Główną zaletą pozostaje więc dostępność i prostota obsługi, natomiast wyniki niniejszych badań pozwalają prowadzić pomiary uwzględniające błędy pomiarowe testowanej metody. Ocenę metody CS należy uzupełnić informacją, iż omawiany eksperyment prowadzony był w wymagających warunkach pomiarowych. Duże zagęszczenie koron drzew utrudnia odbiór sygnału GPS, co zmniejsza dokładność wyznaczanej pozycji. W przypadku urządzeń profesjonalnych, wykorzystanych do przygotowania modelu GT1, użyto zewnętrznej anteny na 2-metrowej tyczce celem poprawy odbioru sygnałów GNSS, natomiast w przypadku smartfona nie ma takiej możliwości. Dodatkowo podczas przygotowywania modelu GT1 operatorzy dostrzegli, iż pomiar wysokości jest utrudniony lub wręcz niemożliwy w kierunku pod światło (oślepienie operatora przez wizjer lunety dalmierza), w przypadku metody CS nie stwierdzono tego typu utrudnień. Aplikacja GLOBETrees została stworzona do amatorskich pomiarów wysokości drzew, wykonane podczas eksperymentu testy potwierdzają, iż jest to wiarygodne i godne polecenia narzędzie Citizen Science.

\section{Bibliografia}

Baatz M., Schäpe A., Strobl J., 2000. Multiresolution Segmentation: an optimization approach for high quality multi-scale image segmentation. In: Angewandte Geographische Informationsverarbeitung XII. Beiträge zum AGIT Symposium Salzburg 2000. Herbert Wichmann Verlag, Karlsruhe, 12-23. https://pdfs.semanticscholar.org/364c/c1ff514a2e11d21a101dc072575e5487d17e.pdf [dostęp: 27.03.2020].

Giętkowski T., 2013. Neogeografia i inne nowe przedmioty. http://krajobraz.ukw.edu.pl/?p=747 [dostęp: 24.03.2020].

Gul M., 2018. Smart Citizens: Artificial Intelligence and Citizen Engagement. https://doi.org/10.13140/RG.2.2.23161.98402

Haklay M., 2013. Citizen science and volunteered geographic information: Overview and typology of participation. Crowdsourcing Geographic Knowledge: Volunteered Geographic Information (VGI) in Theory and Practice. https://doi.org/10.1007/978-94-007-4587-2_7

Luna S., Gold M., Albert A., Ceccaroni L., Claramunt B., Danylo O., Haklay M., Kottmann R., Kyba Ch., Piera J., Radicchi A., Schade S., Sturm U., 2018. Developing Mobile Applications for Environmental and Biodiversity Citizen Science: Considerations and Recommendations. In: A. Joly, S. Vrochidis, K. Karatzas, A. Karppinen, P. Bonnet (red.), Multimedia Tools and Applications for Environmental \& Biodiversity Informatics. Multimedia Systems and Applications. Springer, Cham, 9-30. https://doi.org/10.1007/978-3-319-76445-0_2 
Okła K. i in., 2013. Leksykon terminów geomatycznych stosowanych w Lasach Państwowych. W: K. Okła (red.), Geomatyka w Lasach Państwowych. Część II. Poradnik praktyczny. Centrum Informacyjne Lasów Państwowych Warszawa, 323-392. https://www.geomatyka.lasy.gov.pl/documents/25999395/0/Geomatyka+w+LP+cz.+II_skompresowany_wszystko 15MB.pdf/bc9bab13-e690-41f7-ae12-c872ac1bbb6f

Płochocki Z., 1996. Słownik fizyczny. Wiedza Powszechna, Warszawa, 70.

Roick O., Haklay M., Ellul C.D., 2016. GeoKey - open infrastructure for community mapping and science. Human Computation 3(1), 143-159. https://doi.org/10.15346/hc.v3i1.8

Sheppard S.A., Terveen L., 2011. Quality is a verb: The operationalization of data quality in a citizen science community. Paper presented at 7th Annual International Symposium on Wikis and Open Collaboration, WikiSym 2011, Mountain View, CA, United States, 29-38. https://doi.org/10.1145/2038558.2038565

Sieber R.E., Robinson P.J., Johnson P.A., Corbett J.M., 2016. Doing Public Participation on the Geospatial Web. Ann. Am. Assoc. Geogr. 106(5), 1030-1046. https://doi.org/10.1080/24694452.2016.1191325

Stereńczak K., Bałazy R., Brach M., Bronisz A., Bronisz K., Górski D., Grala N., Gupta S., Heinzel J., Koch B., Miscicki S., Straub Ch., Wang Y., Weinacker H., Wojtan R., 2009. Raport końcowy z realizacji tematu "Opracowanie metody inwentaryzacji lasu opartej na integracji danych pozyskiwanych różnymi technikami geomatycznymi”. Część III - Wyniki z zakresu skanowania lotniczego., SGGW, Warszawa, 21-52.

Wężyk P., Solecki K., 2008. Określanie wysokości drzewostanów Nadleśnictwa Chojna w oparciu o lotniczy skaning laserowy (ALS). Arch. Fotogram. Kartogr. Teledet. 18, 663-672.

Giętkowski T., 2013. Neogeografia i inne nowe przedmioty. http://krajobraz.ukw.edu.pl/?p=747 [dostęp: 24.03.2020]. 
Paulina Terlecka ${ }^{1}$, Karol Terlecki $\mathbb{D}^{2}$

\title{
Prozdrowotne właściwości alantoiny
}

\author{
Pro-health properties of allantoin
}

\begin{abstract}
Wstęp
Alantoina jest składnikiem biologicznie czynnym u wielu gatunków roślin z różnych rodzin m.in.: Boraginaceae, Ericaceae, Fabaceae, Hippocastanaceae, Plataginaceae i Platanaceae. Fitozwiązek ten występuje w: (i) korzeniach żmijowca zwyczajnego (Echium vulgare L.) i żywokostu lekarskiego (Symphytum officinale L.), (ii) liściach: kasztanowca pospolitego (Aesculus hippocastanum L.), mącznicy lekarskiej (Arctostaphylos uva-ursi) L., soi owłosionej (Glycine $\max$ L.), babki lancetowatej (Plantago lanceolata L.), babki zwyczajnej (P. major L.) i robinii akacjowej (Robinia pseudoacacia L.), (iii) zielu nostrzyka lekarskiego (Melilotus officinalis L.), (iiii) owocni fasoli zwyczajnej (Phaseolus vulgaris L.), (iiiii) nasionach kąkolu polnego (Agrostemma githago L.) [Vrbaški $\mathrm{i}$ in. 1978, Wells i Lees 1992, Czerpak i Jabłońska-Trypuć 2008, Jabłońska-Trypuć i Czerpak 2008, Baibado i Cheung 2010, Saeed i in. 2014, Lamer-Zarawska i in. 2015, Dresler i in. 2017].

Zawartość alantoiny $\mathrm{w}$ wybranych gatunkach $\mathrm{z}$ rodziny Boraginaceae wyniosła $0,63-11,81 \mathrm{mg} \cdot \mathrm{g}^{-1} \mathrm{~s} . \mathrm{m}$., a liściach $0,08-35,89 \mathrm{mg} \cdot \mathrm{g}^{-1} \mathrm{~s} . \mathrm{m}$. Największą koncentrację alantoiny stwierdzono w pędach Cynoglossum creticum, Echium italicum, Echium vulgare, Symphytum officinalis, z kolei w liściach: Echium italicum, Echium russicum, Pulmonaria mollis, Pulmonaria obscura i Symphytum officinalis (tab. 1) [Dresler i in. 2017].

Alantoina należy do grupy organicznych związków chemicznych, jest heterocykliczną pochodną mocznika [Zitnanová i in. 2004, Igile i in. 2014, Kapuścińska i Nowak 2014]. Substancja ta jest naturalnym związkiem chemicznym wytwarzanym przez wiele organizmów, w tym zwierzęta, bakterie i rośliny [Igile $\mathrm{i}$ in. 2014]. Alantoina wykazuje działanie keratolityczne, stymuluje podziały komórkowe i przyspiesza regenerację uszkodzonego naskórka [Szymańska 2012]. Dzięki właściwościom silnie nawilżającym wykorzystuje się ją w wielu

\footnotetext{
${ }^{1}$ Uniwersytet Medyczny w Lublinie, Katedra i Klinika Pneumonologii, Onkologii i Alergologii, paulina.chwil@gmail.com

${ }^{2}$ Uniwersytet Medyczny w Lublinie, Katedra i Klinika Chirurgii Naczyń i Angiologii
} 
Tabela 1. Zawartość alantoiny w pędach i korzeniach roślinnych surowców z rodziny Boraginaceae [Dresler i in. 2017]

\begin{tabular}{|l|c|c|c|}
\hline \multicolumn{2}{|c|}{ Gatunek } & \multicolumn{2}{c|}{$\begin{array}{c}\text { Zawartość alantoiny } \\
\mathrm{mg}^{-1} \mathrm{~s} . \mathrm{m} .\end{array}$} \\
\hline Nazwa łacińska & Nazwa polska & pęd & korzeń \\
\hline Anchusa azurea Mill. & farbownik lazurowy & $\mathrm{nb}$. & 0,21 \\
Anchusa undulate subsp. Hybryda Ten. & farbownik falisty & 2,44 & 0,08 \\
Borago officinalis L. & farbownik lekarski & 0,83 & $\mathrm{nb}$. \\
Buglossoides purpureocaerulea L. & nawrot czerwonobłękitny & 2,93 & 1,86 \\
Cerinthe minor L. & ośmiał mniejszy & 0,67 & 0,21 \\
Cynoglossum creticum Miller & ostrzeń kreteński & 9,59 & 0,66 \\
Echium italicum L. & żmijowiec zwyczajny & 7,41 & 34,89 \\
Echium russicum J. F. Gmel. & żmijowiec czerwony & 0,91 & 10,85 \\
Echium vulgare L. & żmijowiec zwyczajny & 11,81 & 0,61 \\
Lindelofia macrostyla (Bunge) Popov & - & 2,36 & 11,98 \\
Lithospermum officinale L. & nawrot lekarski & 0,99 & 0,81 \\
Nonea lutea Desr. DC. & zapłonka żółta & 1,04 & 0,60 \\
Omphalodes verna Moench & ułudka wiosenna & 1,84 & 6,92 \\
Pulmonaria mollis Wulfen ex Hornem. & miodunka miękkowłosa & 1,04 & 9,75 \\
Pulmonaria obscura Dumort. & miodunka ćma & 2,34 & 13,14 \\
Symphytum caucasicum Bieb. & żywokost kaukaski & 0,63 & 7,19 \\
Symphytum officinalis L. & żywokost lekarski & 9,38 & 25,77 \\
\hline
\end{tabular}

nb. - nie stwierdzono

gałęziach przemysłu kosmetycznego i farmacetycznego [Song 2003, Araújo i in. 2010, Ke i in. 2016, Alexandrovich i in. 2017, Silva i in. 2018]. Na rynku farmaceutycznym alantoina występuje w maściach, kremach i żelach. Alantoina znalazła zastosowanie w medycynie. Działa wspomagająco w leczeniu wielu schorzeń skóry [Becker i in. 2010, Igile i in. 2014, Savić i in. 2015a, b].

Celem pracy było określenie działania leczniczego alantoiny w medycynie na podstawie przeglądu opublikowanych w ostatnich latach badań.

\section{Działanie lecznicze alantoiny}

Alantoina pobudza ziarninowanie ran, regenerację naskórka i przyśpiesza procesy naskórkowania. Korzystnie wpływa na złuszczanie tkanki martwiczej skóry, oczyszcza rany, wykazuje działanie keratolityczne. Przyspiesza proces gojenia, promuje proliferację komórek i jest zalecana wspomagająco w leczeniu trudno gojących się ran [Araújo i in. 2010, Alexandrovich i in. 2017, Fernández-Ginés i in. 2017, Sakthiguru i Sithique 2020]. 
Stwierdzono, że wyizolowane ekstrakty z korzeni żywokostu szorstkiego (Symphytum asperum Lepech.) i żywokostu bulwiastego (S. caucasicum M. Bieb.), zawierające alantoinę, stosowane zewnętrznie pobudzają proliferację komórek uczestniczących w procesie gojenia ran (tworzenie ziarniny, naskórka), jednakże ze względu na zawartość niewielkich ilości hepatotoksycznych alkaloidów pirolizydynowych nie jest możliwe zastosowanie wewnętrzne tych wyciągów [Barbakadze i in. 2009].

Zastosowanie żelu $\mathrm{z}$ alantoiną miało pozytywny wpływ na gojenie się ran oparzeniowych w badaniu przeprowadzonym na szczurach w porównaniu z grupą kontrolną [Durmus i in. 2012]. Doniesienia literaturowe innych autorów potwierdzają skuteczne działanie alantoiny w terapii m.in. owrzodzeń podudzi, odleżyn, oparzeń, stanów zapalnych skóry, przewlekłych wyprysków, łuszczycy [James i in. 2003, Farber i Ryan 2015, 2016]. Udokumentowano skuteczność alantoiny (zmniejszenie stanu zapalnego, zaczerwienienia oraz uczucia świądu) $w$ takich schorzeniach jak: wyprysk, pokrzywka, atopowe zapalenie skóry, opryszczkowe zapalenie skóry, kontaktowe zapalenie skóry, trądzik, łuszczyca, łupież, pielęgnacja suchej, popękanej lub postarzałej skóry [Saeedi i in. 2003, Temiz i in. 2009, Farber 2014a, b].

\section{Współczesne badania nad fitoterapeutycznym działaniem alantoiny}

Badanie kliniczne przeprowadzone w grupie 61 kobiet, u których wykonano planowe cięcie cesarskie, potwierdziło skuteczność miejscowego stosowania na bliznę pooperacyjną żelu zawierającego ekstrakt z Allium cepa, alantoinę i heparynę. Zaobserwowano poprawę wyglądu, wygładzenie, a także działanie rozluźniające tkankę blizny [Ocampo-Candiani i in. 2014]. Wykazano również skuteczność tego żelu w zapobieganiu i zmniejszeniu częstotliwości powstawania keloidów i blizn przerosłych oraz bliznowacenia u pacjentów po laserowym usuwaniu tatuaży [Ho i in. 2006]. Również Willital i Simon [2013] w badaniach przeprowadzonych na grupie 1268 pacjentów potwierdzili skuteczność tego żelu w poprawie koloru i elastyczności blizn, zmniejszeniu dolegliwości bólowych, napięciu i świądzie oraz zapobieganiu nadmiernemu bliznowaceniu i pobudzaniu prawidłowego procesu gojenia. Ponadto zaobserwowano zmniejszenie średnich wymiarów blizn (o 31,5\% szerokości i o 47,5 \% wysokości). Kolejne badanie przeprowadzone przez Campanati i in. [2010] wykazało, że miejscowe stosowanie tego żelu dwa razy dziennie przez 24 tygodnie znacząco zmniejszało neoangiogenezę $\mathrm{w}$ przerosłych bliznach i bliznowcach, prowadząc do poprawy wyglądu zmian skórnych.

W innym wieloośrodkowym badaniu przeprowadzonym w grupie 281 dorosłych osób z łagodną lub umiarkowaną postacią atopowego zapalenia skóry (AZS) u 145 pacjentów stosowano krem z alantoiną, kwasem glicyretynowym, ekstraktem z liści winorośli i telmesteiną. Po 50-dniowym leczeniu zaobserwowano wyraźną poprawę kondycji skóry i łagodzenie objawów AZS w porównaniu z grupą kontrolną [Abramovits i Boguniewicz 2006, Reuter i in. 2010]. 
Veraldi i in. [2009] wykazali skuteczność preparatu, który zawierał m.in. alantoinę, kwas glicyretynowy, telmesteinę, alfa-bisabolol, glicynę kapryloilową, kwas hialuronowy, masło shea i octan tokoferylu, w łagodzeniu świądu w grupie dorosłych pacjentów z łagodną lub umiarkowaną postacią AZS. Stosowanie tego kremu w ocenie tolerancji klinicznej w zakresie działania przeciwświądowego w skali wizualno-analogowej (Visual Analogue Scale, VAS) wykazało znaczącą statystycznie poprawę dolegliwości. Wśród działań niepożądanych miejscowe pieczenie zostało wymienione jako częste, jednak łagodne powikłanie [Veraldi i in. 2009].

\section{Alantoina w procesach metabolicznych organizmu}

Choroba Leśniowskiego-Crohna (ang. Crohn's disease, CD) należy do nieswoistych zapaleń jelit. Charakteryzuje się pełnościennym ziarniniakowym zapaleniem mogącym lokalizować się w każdym odcinku przewodu pokarmowego. Najczęstszą jednak lokalizacją jest końcowy fragment jelita krętego, a odcinkowe zmiany zapalne przedzielone są zdrową tkanką. W przebiegu choroby dochodzi do powstawania przetok i zwężeń przewodu pokarmowego, obserwowane są okresy remisji i zaostrzeń, co więcej niejednokrotnie w wyniku powikłań konieczne staje się przeprowadzenie operacji. Stres oksydacyjny bierze udział w promowaniu stanu zapalnego. Alantoinę opisano jako biomarker stresu oksydacyjnego w ludzkiej surowicy krwi i moczu. Przeprowadzono badania na myszach z CD mające na celu wykazanie użyteczności alantoiny jako biomarkera stanu zapalnego. Poziom alantoiny był skorelowany z uszkodzeniem tkanek okrężnicy u przebadanych myszy. Stwierdzono, że alantoina jest biomarkerem zapalenia jelit i stanowi potencjalny biomarker diagnostyczny, który może pomóc w identyfikacji ludzi z CD [Dryland i in. 2008].

W badaniu przeprowadzonym na modelu zwierzęcym SHR (ang. spontaneously hypertensive rat) Chen i in. [2014] wykazali hipotensyjne właściwości alantoiny. Leki imidazolinowe będące agonistami receptorów imidazoliny I-1 (I-1R) stosuje się w leczeniu nadciśnienia tętniczego (NT). Pochodne guanidyny mają zdolność do aktywacji receptorów imidazoliny, $\mathrm{z}$ kolei budowa chemiczna alantoiny jest zbliżona do tych pochodnych. W badaniach nad wpływem alantoiny na receptory I-1 w modelu zwierzęcym wykazano, że jej zastosowanie najefektywniej zmniejszało ciśnienie krwi u szczurów po 30 min, a także znacznie zwiększało obwodowy przepływ. Co ważne, działania te zostały zmniejszone po zastosowaniu efaroksanu w dawce wystarczającej do zablokowania I-1R. Autorzy sugerują, że alantoina, jako agonista I-1R, w przyszłości mogłaby poszerzyć pulę dostępnych środków o działaniu hipotensyjnym, istnieje jednak konieczność przeprowadzenia badań klinicznych [Sączewski i in. 2000, Chen i in. 2014]. Przypuszcza się, że związki imidazolowe mogą brać udział w leczeniu cukrzycy i otyłości [Bousquet 1995, De Luca i in. 2000, Widecka 2007]. 
Działanie alantoiny na stężenie glukozy badano w osoczu szczurów z cukrzycą indukowaną streptozocyną. Wykazano, że alantoina zależnie od dawki redukowała glikemię, co więcej zwiększała produkcję $\beta$-endorfin, a także wychwyt radioaktywnej glukozy przez mięśnie szkieletowe, pobudzając również ekspresję genu GLUT4 [Widecka 2007, Niu i in. 2010]. W badaniach prowadzonych na myszach karmionych wysokotłuszczową dietą (HFD) stwierdzono korzystny wpływ alantoiny na metabolizm lipidów poprzez aktywację I-1 R [Chung i in. 2013].

\section{Podsumowanie}

Alantoina jest w szerokim zakresie stosowana w medycynie, wspomagająco w leczeniu wielu schorzeń skóry, w preparatach o działaniu miejscowym. Badane jest zastosowanie alantoiny $w$ niektórych chorobach układowych, takich jak nadciśnienie tętnicze, otyłość, cukrzyca, a także chorobie Leśniowskiego-Crohna.

\section{Bibliografia}

Abramovits W., Boguniewicz M., 2006. A multicenter, randomized, vehicle-controlled clinical study to examine the efficacy and safety of MAS063DP (Atopiclair) in the management of mild to moderate atopic dermatitis in adults. J. Drugs Dermatol. 5(3), 236-244.

Alexandrovich F.P., Anatolievich N.V., Nikolaevich C.Y., Vitalievna B.A., Ivanovich S.A., Ilinichna P.S., 2017. Preclinical study of the efficacy and safety of wound healing gel containing chitosan, taurine and allantoin. Res. Res. Pharmacol. 3(2), 14-28. https://doi.org/10.18413/2313-8971-2017-3-2-14-28

Araújo L.U., Grabe-Guimarães A., Mosqueira V.C.F., Carneiro C.M., Silva-Barcellos, N.M., 2010. Profile of wound healing process induced by allantoin. Acta Cir. Bras. 25(5), 460-461.

Baibado J.T., Cheung H.Y., 2010. Seed extract of horse chestnut (Aesculus hippocastanum L., 七葉樹) as effective medication for chronic venous insufficiency and other health benefits. HKPJ 17(4), 156-162.

Barbakadze V., Mulkijanyan K., Gogilashvili L., Amiranashvili L., Merlani M., Novikova Z., Sulakvelidze M., 2009. Allantoin-and pyrrolizidine alkaloids-free wound healing compositions from Symphytum asperum. Bull. Georg. Natl. Acad. Sci. 3(1), 159-164.

Becker L.C., Bergfeld W.F., Belsito D.V., Klaassen C.D., Marks J.G., Shank R.C., Slaga T.J., Snyder P.W., Andersen F.A., 2010. Final report of the safety assessment of allantoin and its related complexes. Int. J. Toxicol. 29(3), suppl., 84S-97S. https://doi.org/10.1177/1091581810362805

Bousquet P., 1995. Imidazoline receptors: From basic concepts to recent developments. J. Cardiovasc. Pharmacol. 26 (supl. 2), 1-6.

Campanati A., Savelli A., Sandroni L., Marconi B., Giuliano A., Giuliodori K., Ganzetti G., Offidani A., 2010. Effect of Allium cepa-allantoin-pentaglycan gel on skin hypertrophic scars: Clinical and video-capillaroscopic results of an open-label, controlled, nonrandomized clinical trial. Dermatol. Surg. 36(9), 1439-1444. https://doi.org/10.1111/j.1524-4725.2010.01654.x

Chen M., Tsai J., Chen L., Wu T., Yang J., Yin L., Yang Y., Chiang T., Lu H., Wu M., 2014. Antihypertensive action of allantoin in animals. Biomed. Res. Int. 690135. https://doi.org/10.1155/2014/690135

Chung H., Lee K., Cheng J., 2013. Decrease of obesity by allantoin via imidazoline I1-receptor activation in high fat diet-fed mice. Evid. Based Complement. Alternat. Med. 589309, 1-7. https://doi.org/10.1155/2013/589309 
Czerpak R., Jabłońska-Trypuć A., 2008. Roślinne surowce kosmetyczne. MedPharm Polska, Wrocław.

De Luca N., Izzo R., Fontana D., Iovino G., Argenziano L., Vecchione C., Trimarco B., 2000. Haemodynamic and metabolic effects of rilmenidine in hypertensive patients with metabolic syndrome X. A double-blind parallel study versus amlodipine. Am. J. Hypertension 18, 1515-1522.

Dresler S., Szymczak G., Wójcik M., 2017. Comparison of some secondary metabolite content in the seventeen species of the Boraginaceae family. Pharm. Biol. 55(1), 691-695. https://doi.org/10.1080/13880209.2016.1265986

Dryland P.A., Love D.R., Walker M.F., Dommels Y., Butts C., Rowan D., Copp B.R., 2008. Allantoin as a biomarker of inflammation in an inflammatory bowel disease mouse model: NMR analysis of urine. Open Bio. Com. J. 1(1), 1-6. https://doi.org/10.2174/1874847300801010001

Durmus A.S., Yaman M., Can H.N., 2012. Effects of extractum cepae, heparin, allantoin gel and silver sulfadiazine on burn wound healing: an experimental study in a rat model. Vet. Med. Czech. 57(6), 287-292.

Farber E., 2014a. Compositions and methods of treatment of inflammatory skin conditions using allantoin. U.S. Patent Application 13/019, 039.

Farber E., 2014b. Compositions and Methods of Treatment of Inflammatory Skin Conditions Using Allantoin. U.S. Patent Application 14/226, 419.

Farber E., Ryan R., 2015. Methods of treating psoriasis using allantoin. U.S. Patent 9,095,574.

Farber E., Ryan R., 2016. Methods of treating psoriasis using allantoin. U.S. Patent 9,339,492.

Fernández-Ginés F.D., Muñoz-García S., Rodriguez-Cuadros T.B., Sierra-García F., CuadradoMolina E., 2017. PP-011 Eosin with allantoin mixture for the treatment of periostomal ulcers. a stability study. Eur. J. Hosp. Pharm. 24(1), 206-207. https://doi.org/10.1136/ejhpharm2017-000640.458

Ho W.S., Ying S.Y., Chan P.C., Chan H.H., 2006. Use of onion extract, heparin, allantoin gel in prevention of scarring in Chinese patients having laser removal of tattoos: a prospective randomized controlled trial. Dermatol. Surg. 32(7), 891-896. https://doi.org/10.1111/j.15244725.2006.32192.x

Igile G., Essiet G., Uboh F., Edet E., 2014. Rapid method for the identification and quantification of allantoin in body creams and lotions for regulatory activities. Int. J. Curr. Microbiol. App. Sci. 3(7), 552-557.

Jabłońska-Trypuć A., Czerpak R., 2008. Część teoretyczna i ćwiczenia laboratoryjne. Surowce kosmetyczne i ich składniki. MedPharm Polska, Wrocław.

James T.J., Hughes M.A., Cherry G.W., Taylor R.P., 2003. Evidence of oxidative stress in chronic venous ulcers. Wound Repair Regen. 11(3), 172-176. https://doi.org/10.1046/j.1524475X.2003.11304.X

Kapuścińska A., Nowak I., 2014. Wykorzystanie mocznika i jego pochodnych w przemyśle kosmetycznym. Chemik 68(2), 91-96.

Ke M., Wahab J.A., Hyunsik B., Song K.H., Lee J.S., Gopiraman M., Kim I.S., 2016. Allantoin-loaded porous silica nanoparticles/polycaprolactone nanofiber composites: fabrication, characterization, and drug release properties. RSC Advances 6(6), 4593-4600.

Lamer-Zarawska E., Chwała C., Gwardys A., 2015. Rośliny w kosmetyce i kosmetologii przeciwstarzeniowej. PZWL, Warszawa.

Niu C.S., Chen W., Wu H.T., Cheng K.C., Wen Y.J., Lin K.C., Cheng J.T., 2010. Decrease of plasma glucose by allantoin, an active principle of yam (Dioscorea spp.), in streptozotocininduced diabetic rats. J. Agric. Food Chem. 58(22), 12031-12035.

Ocampo-Candiani J., Vazquez-Martinez O.T., Benavides J.L.I., Buske K., Lehn A., Acker C., 2014. The prophylactic use of a topical scar gel containing extract of Allium cepae, allantoin, and heparin improves symptoms and appearance of cesarean-section scars compared with untreated scars. J. Drugs Dermatol. 13(2), 176-182.

Reuter J., Merfort I., Schempp C.M., 2010. Botanicals in dermatology. Am. J. Clin. Dermatol. 11(4), 247-267. 
Sączewski F., Kobierska E., Dębowski T., Trzeciak H., Krzystanek E., Krzystanek M., Gdaniec M., Nowak E., 2000. Wpływ niektórych pochodnych 2-imidazoliny na ciśnienie tętnicze krwi i częstość akcji serca szczurów szczepu Wistar. Arterial Hypert. 4(3), 173-180.

Saeed F., Jahan N., Ahmad M., 2014. In vivo evaluation \& safety profile evaluation of Arctostaphylos uva-ursi (L.) Spreng. extract in rabbits. Pak. J. Pharm. Sci. 27(6), 2197-2205.

Saeedi M., Morteza-Semnani K., Ghoreishi M.R., 2003. The treatment of atopic dermatitis with licorice gel. J. Dermatol. Treat. 14(3), 153-157. https://doi.org/10.1080/09546630310014369

Sakthiguru N., Sithique M.A., 2020. Fabrication of bioinspired chitosan/gelatin/allantoin biocomposite film for wound dressing application. Int. J. Biol. Macromol. 152(1), 873-883. https://doi.org/10.1016/j.ijbiomac.2020.02.289.

Savić V.L., Nikolić V.D., Arsić I.A., Stanojević L.P., Najman S.J., Stojanović S., Mladenović-Ranisavljević I.I., 2015a. Comparative study of the biological activity of allantoin and aqueous extract of the comfrey root. Phytot. Res. 29(8), 1117-1122. https://doi.org/10.1002/ptr.5356

Savić V.L., Savić S.R., Nikolić V.D., Nikolić L.B., Najman S.J., Lazarević J.S., Dorđević A.S., 2015b. The identification and quantification of bioactive compounds from the aqueous extract of comfrey root by UHPLC-DAD-HESI-MS method and its microbial activity. Hem. Ind. 69(1), 1-8.

Silva D.M. da, Martins J.L.R., Oliveira D.R. de, Florentino I.F., Silva D.P.B. da, Santos F.C.A. dos, Costa E.A., 2018. Effect of allantoin on experimentally induced gastric ulcers: pathways of gastroprotection. Eur. J. Pharmacol. 821, 68-78. https://doi.org/10.1016/j.ejphar.2017.12.052

Song L.I.U., 2003. Simultaneous determination of allantoin and panthenol in cosmetics by reversed-phase high performance liquid chromatography. Chin. J. Chromat. 44-52.

Szymańska E., 2012. Alantoina - właściwości gojące i przeciwzapalne. Pediatr. Med. Rodz. 8(1), $73-77$.

Temiz C., Temiz P., Sayin M., Ucar K., 2009. Effect of cepea extract-heparin and allantoin mixture on epidural fibrosis in a rat hemilaminectomy model. Turk. Neurosurg. 19(4), 387-392.

Veraldi S., De P.M., Schianchi R., Lunardon L., 2009. Treatment of pruritus in mild-to-moderate atopic dermatitis with a topical non-steroidal agent. J. Drugs Dermatol. 8(6), 537-539.

Vrbaški M.M., Grujić-Injac B., Gajić D., 1978. A new method for allantoin determination and its application in allantoin determination in Agrostemma githago L. seed. Analyt. Biochem. 91(1), 304-308. https://doi.org/10.1016/0003-2697(78)90844-8

Wells X.E., Lees E.M., 1992. Properties of allantoinase from whole developing fruits of French bean, Phaseolus vulgaris L. Funct. Plant Biol. 19(3), 201-211. https://doi.org/10.1071/PP9920201

Widecka K., 2007. Leki $\alpha$-adrenolityczne i działajace centralnie. Art. Hypert. 11A, 1-29.

Willital G.H., Simon J., 2013. Efficacy of early initiation of a gel containing extractum cepae, heparin, and allantoin for scar treatment: an observational, noninterventional study of daily practice. J. Drugs Dermatol. 12(1), 38-42.

Zitnanová I., Korytár P., Aruoma O.I., Sustrová M., Garaiová I., Muchová J., Kalnovicová T., Pueschel S., Duracková Z., 2004. Uric acid and allantoin levels in down syndrome: antioxidant and oxidative stress mechanisms? Clin. Chim. Acta. 341(1-2), 139-146. https://doi.org/10.1016/j.ccen.2003.11.020 


\title{
Eliza Wargala ${ }^{1}$, Agnieszka Weremczuk ${ }^{1}$, Mirosława Chwil $\mathbb{1}^{2}$
}

\section{Arbutyna - składnik ziół}

\author{
Arbutine - herbs component
}

\begin{abstract}
Wstęp
Arbutyna, glukozyd hydrochinonu $\left(\mathrm{C}_{12} \mathrm{H}_{16} \mathrm{O}_{7}\right)$, jest organicznym związkiem chemicznym $\mathrm{z}$ grupy glikozydów fenolowych. Fitozwiązek ten występuje $\mathrm{w}$ dwóch formach pochodnych: hydrochinonu $\alpha$ lub $\beta$-arbutyny [Garcia-Jimenez i in. 2017]. Arbutyna ma postać białych połyskujących igiełek, a produktem jej rozkładu jest hydrochinon [Nakano i in. 2005].

Arbutyna łagodzi przebarwienia skórne. Jest wykorzystywana w hiperpigmentacjach skóry wywołanych stanami zapalnymi i zwiększoną aktywnością melanocytów [Zasada 2016]. Stosuje się ją jako środek depigmentujący [Garcia-Jimenez i in. 2017]. Substancja ta jest również inhibitorem aktywności tyrozynazy, kluczowego regulatora syntezy melaniny. Hamowanie aktywność tyrozynazy powodowało zmniejszenie poziomu melaniny w melanocytach, $\mathrm{w}$ wyniku czego uzyskiwano lepszy efekt depigmentacyjny oparty na zmniejszeniu ilości melaniny na powierzchni skóry [Engler-Jastrzębska $i$ in. 2019]. Wśród związków stosowanych $\mathrm{w}$ dermatologii arbutyna jest jedną z najskuteczniejszych substancji rozjaśniających. Substancja ta jest bezpiecznym i efektywnym związkiem w eliminowaniu zmian barwnikowych skóry, m.in. piegów, ostudy, melanozy i plam soczewicowatych oraz przebarwień okołoustnych, pozapalnych i po odczynach fototoksycznych [Morąg i in. 2013, 2015]. Arbutynę wykorzystuje się w produkcji kosmetyków wybielających skórę [Ekiert i in. 2012]. Fitozwiazek ten wykazuje aktywność przeciwbakteryjną i antyoksydacyjną [Pavlović 2009, Nycz i in. 2010]. Jest stosowany w leczeniu dróg moczowych [Schindler i in. 2002, Zhu i in. 2018].

Celem pracy było określenie występowania i działania oraz wykorzystania arbutyny na podstawie przeglądu literatury.

\footnotetext{
${ }^{1}$ Uniwersytet Przyrodniczy w Lublinie, Wydział Biologii Środowiskowej, Studenckie Koło Naukowe Biologów, sekcja Biokosmetologii, eliza.wargala@gmail.com

${ }^{2}$ Uniwersytet Przyrodniczy w Lublinie, Wydział Biologii Środowiskowej, Katedra Botaniki i Fizjologii Roślin
} 


\section{Występowanie arbutyny u wybranych gatunków roślin}

Arbutyna występuje $\mathrm{u}$ wielu gatunków roślin z różnych rodzin: Saxifragaceae (skalnicowate), Ericaceae (wrzosowate), Rosaceae (różowate), Lamiaceae (jasnotowate) i Asteraceae (astrowate) [Pop i in. 2009, Ekiert i in. 2012, Horoszkiewicz i Kulza 2012, Morąg 2012].

\section{Saxifragaceae}

Wśród wielu gatunków roślin z rodziny Saxifragaceae rodzaj Bergenia wyróżnia się wysoką koncentracją arbutyny. Surowcem leczniczym u roślin z rodzaju Bergenia są liście (Bergeniae folium) i kłącza (Bergeniae rhizoma) [Lewkowicz-Mosiej 2013]. Zawartość arbutyny w liściach bergenii grubolistnej (Bergenia crassifolia L.) wynosiła 17,4-22,6\% s.m. [Pop i in. 2009]. Z kolei stężenie tej substancji $\mathrm{u}$ B. purpurascens mieściło się $\mathrm{w}$ granicach 1,5-6,4\% [Jiang $\mathrm{i}$ in. 2010]. W badaniach innych autorów zawartość arbutyny w Bergeniae folium u czterech gatunków bergenii: $B$. crassifolia, B. cordifolia, B. purpurascens $i$ B. ciliata, wynosiła odpowiednio: 122,3, 23,5, 16,1 i 13,6 mg/g s.m. [Rychlinska i Nowak 2012].

\section{Ericaceae}

W rodzinie Ericaceae arbutynę stwierdzono u mącznicy lekarskiej (Arctostaphylos uva-ursi (L.) Spren.), borówki brusznicy (Vaccinium vitis-idaea L.), wrzosu zwyczajnego (Calluna vulgaris (L.) Hull) i bagna pospolitego (Ledum palustre L.). Arbutyna w kwiatach wrzosu zwyczajnego (Callunae flos) stanowiła około 0,5\% [Wichtl 1997]. Z kolei w zielu bagna pospolitego (Ledum palustre L.) koncentracja tej substancji wynosiła 1,6 mg/g s.m. [Rychlinska i Nowak 2012]. Natomiast w surowcach Uvae-ursi folium i Vitis idaeae folium zawartość arbutyny mieściła się w przedziałach odpowiednio 3-12 i 5-7\% [Morąg 2012] lub wynosiła odpowiednio 90,5 i 51,7 mg/g s.m. [Rychlinska i Nowak 2012]. W innych badaniach u Arctostaphylos uva-ursi zawartość arbutyny mieściła się w granicach 5-12\%, a hydrochinonu i garbników 10-20\%. Surowiec Uvae-ursi folium jest dobrze znany w leczeniu bakteryjnych chorób zapalnych, korzystne efekty uzyskano, stosując $3 \mathrm{~g}$ s.m. tego ziela lub 400-800 mg pochodnych hydrochinonu cztery razy dziennie [Gohari i Saeidnia 2014]. Według Morąg [2012] w liściach mącznicy lekarskiej głównymi substancjami czynnymi były glikozydy fenolowe: arbutyna, metyloarbutyna, galoiloarbutyna, hydrochinon i metylohydrochinon. Arbutynę zidentyfikowano również u Arbutus unedo L., Pyrola japonica Klenze, Vaccinium dunalianum Wight., $V$. koreanum Nakai i $V$. vacillans Torr. [Jiang i Xiao 1986, Xu i in. 2015].

\section{Rosaceae}

W rodzinie Rosaceae znaczną zawartość arbutyny stwierdzono u gruszy pospolitej (Pyrus communis L.). Jej koncentracja w surowcach Pyri communis folium 
wynosiła $24,9 \mathrm{mg} / \mathrm{g}$ s.m, natomiast w kwiatach gruszy pospolitej (Pyri communis flos) oscylowała w granicach 1,9-14 mg/g s.m. [Rychlinska i Gudej 2003, Rychlinska i Nowak 2012]. Arbutynę zidentyfikowano również u Pyrus calleryana Dcne., P. pyrifolia Hosui i Sorbaria sorbifolia L. [Jiang i Xiao 1986, Xu i in. 2015].

\section{Lamiaceae}

W rodzinie Lamiaceae arbutynę stwierdzono w zielu majeranka ogrodowego (Majorana hortensis herb), jej zawartość wynosiła 17,3 mg/g s.m. [Rychlinska i Nowak 2012]. Z kolei u serdecznika pospolitego (Leonurus cardiaca (L.) Benth.) i miodownika melisowatego (Melittis melissophyllum L.) koncentracja arbutyny wynosiła odpowiednio 2,6 i 1,8 g/100 g s.m. [Dušková i in. 1999, Kittipongpatana i in. 2007]. Skrzypczak-Pietraszek i in. [2005] podają, że u roślin miodownika melisowatego uprawianych w kulturach in vitro zawartość arbutyny wynosiła 1,8 g/100 g s.m. Obecność tego fitozwiazku stwierdzono także u Loxocalyx urticifolius Hemsl. [Xu i in. 2015].

\section{Asteraceae}

$\mathrm{U}$ roślin z rodziny (Asteraceae) arbutynę stwierdzono m.in. u sierpika pięciolistnego (Serratula quinquefolia Bieb. ex Willd) i jeżówki purpurowej (Echinacea purpurea (L.) Moench.) [Skrzypczak-Pietraszek i in. 2005, Nowak i in. 2009]. W roślinnych Echinacea purpurea uprawianych kulturach in vitro zawartość arbutyny wynosiła 4 g/100 g s.m [Skrzypczak-Pietraszek i in. 2005]. Arbutynę wyizolowano także z korzeni Gerbera pilose (L.) Cass [Ng i in. 1996]. Związek ten zidentyfikowano u Atractylodes japonica Koidz. i Hagnalon rupestre L. [Xu i in. 2015] oraz w liściach karczocha zwyczajnego (Cynara scolymus L.) [Horoszkiewicz i Kulza 2012].

\section{Dzialanie arbutyny}

Arbutyna hamuje syntezę melaniny poprzez redukcję aktywności tyrozynazy. Wynika to $\mathrm{z}$ hamowania tego enzymu w melanosomach i białku Pmel-17. Białka te są odpowiedzialne za tworzenie szkieletu macierzy melanosomalnej, uczestniczą w procesie polimeryzacji i biosyntezy melaniny [Rok i in. 2012, Kilian-Pięta i Hoppe 2019]. Wykazano, że arbutyna może hamować aktywność tyrozynazy i melanogenezę melanocytów [Yang i in. 2004]. W badaniach nad wpływem mieszaniny arbutyny i aloesyny na białka melanogenne stwierdzono, że inhibicja tyrozyny może występować na poziomie potranslacyjnym [Chakraborty i in. 1998].

Dowiedziono, że dobry efekt rozjaśniający ma $\alpha$-arbutyna. Należy jednak uwzględnić, że stosowana w stężeniach $0,5-8 \mathrm{mM}$ może mieć działanie odwrotne, czyli powoduje wzrost pigmentacji skóry. Z kolei kwas kojowy (inhibitor tyrozynazy, uczestniczący w wielu etapach tworzenia melaniny) zastosowany 
w stężeniu 0,5-4 mM zmniejszał pigmentację. Kwas ten jest stosowany w hiperpigmentacji skóry [Nakajima i in. 1998].

W badaniach aktywności antyutleniającej arbutyny wykazano na podstawie testów opartych na fibroblastach i erytrocytach, że arbutyna ma silne działanie przeciwutleniające, porównywalne $\mathrm{z}$ hydrochinonem lub większe od niego. To wskazuje, że fitozwiązek ten działa jako silny przeciwutleniacz w skórze [Petkou i in. 2002, Takebayashi i in. 2010].

Arbutyna nie tylko odznacza się wysoką skutecznością w rozjaśnianiu przebarwień skóry w zaburzeniach hiperpigmentacyjnych, ale jest również bezpieczna i niealergizująca w zewnętrznym stosowaniu. Substancja ta skutecznie rozjaśnia plamy i przebarwienia oraz wyrównuje barwę skóry w zaburzeniach związanych z nadaktywnością melanocytów. To pozwala na szersze jej wykorzystanie jako skutecznego i bezpiecznego związku w preparatach zalecanych do przebarwień skóry [Chakraborty i in. 1998].

\section{Wykorzystanie arbutyny}

Właściwości arbutyny są wykorzystane w wielu dziedzinach nauki: medycynie, farmacji i kosmetologii. Arbutyna dzięki właściwościom leczniczym skutecznie pomaga $\mathrm{w}$ różnego rodzaju stanach zapalnych i dolegliwościach układu moczowego. Wykorzystywana jest $\mathrm{w}$ leczeniu wspomagającym infekcję dróg moczowych i przewlekłe zapalenie pęcherza moczowego oraz ze względu na jej antylitolityczne właściwości [Blumenthal i in. 2000, Ali i in. 2018] - w kamicy nerkowej [Weiss 2001]. W organizmie, arbutyna i jej pochodne ulegają rozkładowi do hydrochinonu, który wykazuje działanie antyseptyczne [Kowal-Gierczak i in. 2007].

Arbutyna jest bardzo pożądaną substancją w pielęgnacji cery, ze względu na wybielające właściwości. Mechanizm działania najczęściej stosowanych w kosmetyce środków rozjaśniających, m.in.: arbutyny, kwasu kojowego, kwasu glikolowego, kwasu azelainowego i fitowego, witaminy $\mathrm{C}$ i jej pochodnych, polega na hamowaniu aktywności tyrozynazy [Bazela 2010]. Arbutyna wykazuje skuteczność w miejscowym leczeniu różnych przebarwień skóry charakteryzujących się nadaktywną funkcją melanocytów. Substancja ta znacząco hamowała wytwarzanie melaniny, co określono przez pomiar rodników eumelaniny. Inhibicja tyrozynazy potwierdza odwracalność arbutyny jako konkurencyjnego inhibitora tego enzymu. Stwierdzono, że mechanizm depigmentacji zachodzący pod wpływem arbutyny obejmuje hamowanie aktywności tyrozynazy melanosomalnej [Maeda i in. 1996]. Niektórzy naukowcy zwracają uwagę na niską rozpuszczalność arbutyny w tłuszczach, a zatem na niską zdolność penetracji naskórka, co utrudnia dostęp do melanocytów w jego warstwie rogowej.

Arbutyna wyizolowana z liści mącznicy lekarskiej działa antymikrobowo. W badaniach in vitro fitozwiązek ten wykazywał skuteczność wobec: Bacillus subtilis, Candida albicans, Enterococcus faecalis, Escherichia coli, Helicobakter 
pylori, Mycoplasma hominis, Proteus vulgaris, Pseudomonas aeruginosa, Shigella flexneri, Shigella sonnei, Staphylococcus aureus i Ureaplasma urealyticum [Moskalenko 1986].

Arbutyna jest stosowana zewnętrznie jako składnik farmaceutyków do miejscowego stosowania w celu redukcji, rozjaśniania i wybielania plam barwnikowych na skórze. Farmaceutyki te występują w postaci kremów lub żeli rozjaśniających i wybielających plamy barwnikowe. Do skutecznych zaliczono m.in. hydrochinon $(2 \%)$ i arbutynę powodujące efekt rozjaśniający przez inhibicję enzymu melanosomów tyrozynazy, a także pochodną witaminy A, izotretinoinę o właściwościach złuszczających [Niewęgłowska-Wilk i in. 2015].

Wykazano skuteczność mikrodermabrazji w redukcji uszkodzeń posłonecznych $\mathrm{w}$ połączeniu $\mathrm{z}$ wybielającym preparatami zawierającymi m.in. arbutynę, $\mathrm{N}$-acetyloglukozaminę i niacynę [Niewęgłowska-Wilk i in. 2011]. Arbutyna jest składnikiem preparatów kosmetycznych występujących na rynku w formie żelu jako serum na przebarwienia i nierównomierne zabarwienie skóry stosowanych podczas jonoforezy kosmetycznej [Wesołowska i in. 2017]. Stwierdzono, że 3\% stężenie arbutyny w mleczku, lotionach i kremach do skóry stosowanych 2 razy dziennie przez 3 miesiące zmniejszało intensywność i wielkość przebarwień skóry [Prakash i Majeed 2009].

Skuteczność i bezpieczeństwo działania arbutyny wskazuje, że może być stosowana przez młodsze i starsze osoby. Szeroka grupa odbiorców preparatów zawierających arbutynę wynika $\mathrm{z}$ jej efektywnego działania depigmentacyjnego $\mathrm{w}$ stosunku do przebarwień wynikających często z przyczyn m.in. fizjologicznych, chorobowych i mechanicznych. Także trwałość tego fitozwiązku w produktach kosmetycznych zasługuje na uwagę.

\section{Podsumowanie}

Arbutyna wykazuje działanie przeciwzapalne, antyoksydacyjne i przeciwmikrobowe oraz depigmentacyjne. Obecnie fitozwiazek ten jest składnikiem kosmetyków o działaniu wybielającym i wyrównujących koloryt skóry. Arbutynę wykorzystuje się w recepturach dermokosmetyków, m.in. maści, kremów i żeli, w głównej mierze zalecanych do stosowania miejscowego w celu depigmentacji plam i przebarwień skóry. W przyszłości wskazane są dalsze badania w celu opracowania nowych, bezpiecznych receptur farmaceutyków zawierających arbutynę o korzystnym działaniu na organizm człowieka, a także doskonalenia przenikania tej substancji przez skórę i eliminowania niepożądanego działania $\alpha$ - i $\beta$-arbutyny. 


\section{Bibliografia}

Ali S.N., Dayarathna T.K., Ali A.N., Osumah T., Ahmed M., Cooper T.T., Power N.E., Zhang D., Kim D., Kim R., Amant A.S., Hou J., Tailly T., Yang J., Luyt L., Spagnuolo P.A., Burton J.P., Razvi H., Leong H.S., 2018. Drosophila melanogaster as a function-based high-throughput screening model for antinephrolithiasis agents in kidney stone patients. Dis. Model. Mech. 11(11), dmm035873. https://doi.org/10.1242/dmm.035873

Bazela K., Dębowska R., Tyszczuk B., Dźwigałowska A., Rogiewicz K., Eris I., 2010. Dermokosmetyki do pielęgnacji skóry z przebarwieniami - ocena skuteczności działania. Dermatol. Estet. 12(55), 320-326.

Blumenthal M., Goldberg A., Brinckmann J. 2000. Herbal medicine: expanded Commission E monographs. Thieme, Stuttgart-New York, 389-391.

Chakraborty A.K., Funasaka Y., Komoto M., Ichihashi M., 1998. Effect of arbutin on melanogenic proteins in human melanocytes. Pigment Cell Res. 11(4), 208-212.

Dušková J., Dušek J., Jahodár L., 1999. Zur biotransformation von hydrochinon zu arbutin in den in vitro-kulturen. Herba Pol. 45(1), 23-26.

Ekiert H., Kwiecień I., Szopa A., Muszyńska B., 2012. Possibilities of arbutin production using plant biotechnology methods. Pol. J. Cosmetol., 15(3), 151-162.

Engler-Jastrzębska M., Musiał C., Kamm A., 2019. Metody niwelowania hiperpigmentacji skóry w świetle nowych doniesień naukowych. Kosmetol. Estet. 5(8), 553-560.

Garcia-Jimenez A., Teruel-Puche J.A., Berna J., Rodriguez-Lopez J.N., Tudela J., Garcia-Canovas F., 2017. Action of tyrosinase on alpha and beta-arbutin: A kinetic study. PLoS One 12(5), e0177330. https://doi.org/10.1371/journal.pone.0177330

Gohari A.R., Saeidnia S., 2014. The role of herbal medicines in treatment of urinary tract diseases. J. Nephrophar. 3(1), 13-14.

Horoszkiewicz M., Kulza M., 2012. Karczoch zwyczajny - niewykorzystane możliwości leku roślinnego w terapii miażdżycy i chorób wątroby. Przegl. Lek. 69(10), 1129-1131.

Jiang H., Guo F., Zhang L., Chen Y., Li S., Yang F., 2010. Comparison of arbutin contents from Bergenia purpurascens in Yunnan. China J. Chin. Materia Med. 35(14), 1812-1814. https://doi.org/10.4268/cjcmm20101408

Jiang J.W., Xiao Q.X., 1986. Handbook of bioactive constituents in plant drugs. People's Health Press, Beijing, China.

Kilian-Pięta E., Hoppe M., 2019. Wpływ melanogenezy na powstawanie przebarwień. Kosmetol. Estet. $4(8), 419-422$.

Kittipongpatana N., Theeraphong T., Srimanee A., Kittipongpatana O.S., 2007. Biotransformation of hydroquinone to arbutin by cell-suspension cultures of three thai solanaceous plants. CMU J. Nat. Sci. 6(2), 219-229.

Kowal-Gierczak B., Lamer-Zarawska E., Niedworok J., 2007. Fitoterapia i leki roślinne. PZWL Wyd. Lekarskie, Warszawa, 366.

Lewkowicz-Mosiej T., 2013. Egzotyczne rośliny lecznicze w domu i w ogrodzie. Wyd. M, Kraków.

Maeda K., Fukuda M., 1996. Arbutin mechanism of its depigmenting action in human melanocyte culture. J. Pharmacol. Exp. Ther. 276(2), 765-769.

Morąg M., 2012. Ocena właściwości kosmetycznych ekstraktu z liści sierpika pięciolistnego w pielęgnacji skóry z przebarwieniami. Rozprawa doktorska, Uniwersytet Medyczny im. K. Marcinkowskiego w Poznaniu, Poznań.

Morąg M., Nawrot J., Siatkowski I., Adamski Z., Fedorowicz T., Dawid-Pac R., Urbanska M., Nowak G., 2015. A double-blind, placebo-controlled randomized trial of Serratulae quinquefoliae folium, a new source of $\beta$-arbutin, in selected skin hyperpigmentations. J. Cosmet. Dermatol. 14(3), 185-190. https://doi.org/10.1111/jocd.12147

Morąg M., Nowak G., Michalak A., 2013. Liście Serratula quinquefolia MB nowym źródłem arbutyny. Post. Fitoter. 1, 17-21.

Moskalenko S., 1986. Preliminary screening of far-eastern ethnomedical plants for antibacterial activity. J. Ethnopharmacol. 15(3), 231-259. 
Nakajima M., Shinoda I., Fukuwatari Y., Hayasawa H., 1998. Arbutin increases the pigmentation of cultured human melanocytes through mechanisms other than the induction of tyrosinase activity. Pigment Cell Res. 11(1), 12-17. https://doi.org/10.1111/j.1600-0749.1998.tb00705.x

Nakano H., Shizuma M., Murakami H., Kiryu T., Kiso T., 2005. One-pot synthesis of glycosyl poly (arbutin) by enzymatic glycosylation followed by polymerization with peroxidase. J. Mol. Catal. B Enzym. 33(1-2), 1-8. https://doi.org/10.1016/j.molcatb.2005.01.001

Ng T.B., Ling J.M., Wang Z.T., Cai J.N., Xu G.J., 1996. Examination of cumarins, flavonoids and polysaccharopeptide for antibacterial activity. Gen. Pharmac. 27(7), 1237-1240.

Niewęgłowska-Wilk M., Wilk T., Kalicińska J., Śpiewak R., 2015. Zapobieganie i sposoby usuwania plam barwnikowych. Kosmetol. Estet. 54(16), 541-545.

Niewęgłowska-Wilk M., Wilk T., Kamińska-Winciorek G., Śpiewak R., 2011. Częstość korzystania i poziom zadowolenia z mikrodermabrazji diamentowej wśród klientek salonu kosmetycznego. Estetol. Med. Kosmetol. 17-19.

Nowak G., Nawrot J., Latowski K., 2009. Arbutin in Serratula quinquefolia M.B. (Asteraceae). Acta Soc. Bot. Pol. 78(2), 137-140.

Nycz J.E., Malecki G., Morag M., Nowak G., Ponikiewski L., Kusz J., Switlicka A., 2010. Arbutin: Isolation, X-ray structure and computional studies. J. Mol. Struc. 980(1-3), 13-17. https://doi.org/10.1016/j.molstruc.2010.06.026

Pavlović R.D., Lakušićć B., Došlov-Kokoruš Z., Kovačević N., 2009. Arbutin content and antioxidant activity of some Ericaceae species. Pharm. Internat. J. Pharm. Sci. 64(10), 656-659.

Petkou D., Diamantidis G., Vasilakakis M., 2002. Arbutin oxidation by pear (Pyrus communis L.) peroxidases. Plant Sci. 162(1), 115-119.

Pop C., Vlase L., Tamas M., 2009. Natural resources containing arbutin. Determination of arbutin in the leaves of Bergenia crassifolia (L.) Fritsch acclimated in Romania. Not. Bot. Agrobot. Cluj. 37(1), 129-132.

Prakash L., Majeed M., 2009. Multifunctional skin tone lighteners from nature: an overview. Euro Cosmet. 6, 19-23.

Rok J., Otręba M., Buszman E., Wrześniok D., 2012. Melanina - z melanocytu do keratynocytu, czyli jak przebiega transport melaniny w skórze. Ann. Acad. Med. Siles. 1(66), 60-66.

Rychlinska I., Gudej J., 2003. Qualitative and quantitative chromatographic investigation of flavonoids in Pyrus communis L. flowers. Acta Pol. Pharm. 60(1), 81-86.

Rychlinska I., Nowak S., 2012. Quantitative determination of arbutin and hydroquinone in different plant materials by HPLC. Ann. Soc. Doct. Stud. Acad. Med. Siles. 40(2), 109-113.

Schindler G., Patzak U., Brinkhaus B., Nieciecki A. von, Wittig J., Krähmer N., Glöckl I., Veit M., 2002. Urinary excretion and metabolism of arbutin after oral administration of Arctostaphylos uvae ursi extract as film-coated tablets and aqueous solution in healthy humans. Br. J. Clin. Pharmacol. 42(8), 920-927. https://doi.org/10.1177/009127002401102740

Skrzypczak-Pietraszek E., Szewczyk A., Piekoszewska A., Ekiert H., 2005. Biotransformation of hydroquinone to arbutin in plant in vitro cultures - preliminary results. Acta Physiol. Plant. 27(1), 79-87.

Takebayashi J., Ishii R., Chen J., Matsumoto T., Ishimi Y., Tai A., 2010. Reassessment of antioxidant activity of arbutin: Multifaceted evaluation using five antioxidant assay systems. Free Radic. Res. 44(4), 473-478. https://doi.org/10.3109/10715761003610760

Weiss R.F., 2001. Weiss s Herbal Medicine. Thieme, Stuttgart-New York, 223-224.

Wesołowska J., Iwan-Ziętek I., Mosiejczuk H., Kemicer-Chmielewska E., Marchlewicz M., 2017. Zastosowanie wybranych bodźców fizykalnych podczas profesjonalnych zabiegów kosmetologicznych. Część I. Prąd galwaniczny jako czynnik wspomagający przezskórny transport substancji aktywnych zawartych w profesjonalnych preparatach kosmetycznych. Pom. J. Life Sci. 63(1), 50-53.

Wichtl M., 1997. Teedrogen und phytopharmaka. Stuttgart, Wissenschaftliche verlagsgesellschaft.

Xu W.H., Liang Q., Zhang Y.J., Zhao P., 2015. Naturally occurring arbutin derivatives and their bioactivities. Chem. Biodiver. 12(1), 54-81. 
Yang Z.Q., Wang Z.H., Tu J.B., Li P., Hu X.Y., 2004. The effects of aloesin and arbutin on cultured melanocytes in a synergetic method. Chinese J. Plas. Sur. 20(5), 369-371.

Zasada M., 2016. Substancje biologicznie czynne stosowane w rozjaśnianiu hiperpigmentacji skóry. Kosm. Estet. 5, 467-473.

Zhu X., Tian Y., Zhang W., Zhang T., Guang C., Mu W., 2018. Recent progress on biological production of $\alpha$-arbutin. Appl. Microbiol. Biot. 102(19), 8145-8152. 
Julia Wójcik ${ }^{1}$, Adam Gawryluk $\mathbb{D}^{2}$, Ilona Woźniak-Kostecka $\mathbb{B}^{2}$

\title{
Zachowania komunikacyjne mieszkańców Lublina w kontekście ochrony środowiska
}

Communication behavior of the Lublin residents in the context of environment conservation

\begin{abstract}
Wstęp
Ochrona środowiska naturalnego jest jednym z najważniejszych zadań, przed jakimi stanął człowiek u progu XXI w. [Tokarczyk 2012]. Jednym ze źródeł zanieczyszczeń środowiska naturalnego jest transport samochodowy, który w europejskich miastach odpowiada za prawie jedną czwartą emisji gazów cieplarnianych i jest główną przyczyną zanieczyszczenia powietrza w miastach [Dzikuć i in. 2017].

Ze względu na rosnące wykorzystywanie paliw kopalnych, a co za tym idzie - wyczerpywanie się ich złóż, należy rozważać wprowadzenie zrównoważonego transportu miejskiego [Goldman i Gorham 2006]. Redukcja liczby użytkowanych samochodów osobowych w miastach jest głównym celem tej polityki [Woodcock i in. 2009]. Wprowadzenie zrównoważonej polityki dotyczącej transportu miejskiego może ograniczyć emisję szkodliwych substancji do środowiska, a w dalszej perspektywie przyczynić się do poprawy zdrowia mieszkańców [Goldman i Gorham 2006, Woodcock i in. 2009]. Ponadto, by zmniejszyć negatywną presję transportu na środowisko, należy ograniczyć ilość przejazdów samochodowych w miastach poprzez wykorzystanie bardziej wydajnych, a co za tym idzie, bardziej ekologicznych środków transportu, oraz dostosować ich wybór w zależności od celu planowanej podróży. Dlatego konieczna jest zmiana zachowań komunikacyjnych mieszkańców miast poprzez wybór alternatywnych form transportu takich jak: pociąg, komunikacja zbiorowa czy rower [Tokarczyk 2012]. Określając główne czynniki decydujące o wyborze danego środka transportu, należy pamiętać, że potrzeby przemieszczania się mieszkańców miast oraz czynniki je determinujące wynikają z przestrzennego rozmieszczenia zasobów, miejsc pracy i terenów mieszkaniowych [Dudziak i in. 2018]. Według Sierpińskiego [2012] potrzeba przemieszczania się w dużej mie-

1 Uniwersytet Przyrodniczy w Lublinie, Wydział Agrobioinżynierii, Katedra Łąkarstwa i Kształtowania Krajobrazu, Zakład Studiów Krajobrazowych i Gospodarki Przestrzennej, julia.wojcik3@wp.pl

${ }^{2}$ Uniwersytet Przyrodniczy w Lublinie, Wydział Agrobioinżynierii, Katedra Łąkarstwa i Kształtowania Krajobrazu, Zakład Studiów Krajobrazowych i Gospodarki Przestrzennej
\end{abstract}


rze uzależniona jest od czynników socjodemograficznych takich jak: wiek, płeć, posiadanie prawa jazdy, status zatrudnienia, liczba dzieci, przychody i posiadanie samochodu czy oddalenie od miejsca podróży. W literaturze przedmiotu można znaleźć wiele kryteriów, którymi kierują się podróżni podczas wyboru środka transportu. Według Tłuczak [2013] wybór środka transportu uzależniony jest od: jego dostępności, preferencji podróżujących, subiektywnych ocen oraz celu podróży. Natomiast Marszałek [2001] uważa, że dokonując wyboru środka transportu, bierze się pod uwagę: zdolność przewozową, częstotliwość jazdy, szybkość i wygodę jazdy. Z kolei Wyszomirski [2008] do podstawowych kryteriów wyboru środka transportu zalicza: czas, wygodę, dostępność, częstotliwość, koszt, bezpieczeństwo, prędkość i pewność. Natomiast Curtis i Perkins [2006] uważają, że na mobilność mieszkańców w miastach oraz na ich sposoby przemieszczania się wpływ mają: koszty podróży, struktura ludności zamieszkującej miasto, status społeczny, stopień zamożności, rodzaj gospodarstwa domowego oraz zagospodarowanie przestrzenne miasta.

Obecnie nie ustalono uniwersalnych kryteriów, którymi kierują się użytkownicy podczas korzystania $\mathrm{z}$ konkretnego środka transportu. Motywacja podróżowania związana jest $\mathrm{w}$ dużej mierze $\mathrm{z}$ typowymi aktywnościami życiowymi człowieka, do których zaliczane są:

- utrzymanie domu: praca, podróże związane z pacą, zakupy (podstawowe i okazjonalne), opieka medyczna, zobowiązania związane z domem, podwożenie/przywożenie domowników;

- rekreacja: rozrywka, hobby, sport, odpoczynek i relaks, udział w wydarzeniach sportowych;

- życie towarzyskie i społeczne: odwiedziny, szkoła, kultura, religia;

- inne: podróże incydentalne [Sierpiński 2012].

Natomiast za najważniejsze czynniki, decydujące o wyborze środka transportu uważa się:

- czynniki czasowe: całkowity czas podróży, czas dojścia do środka transportu, oczekiwania na środek transportu i dotarcia ze środka transportu do celu;

- czynniki przestrzenne: całkowitą odległość od miejsca zamieszkania do celu, odległość do środka transportu, odległość od środka transportu do celu;

- dostępność: liczba przesiadek, pora dnia, miejsca parkingowe;

- czynniki atmosferyczne: temperaturę, opady atmosferyczne, śliską nawierzchnię;

- inne: wybór optymalnej trasy, możliwość bezpośredniego dotarcia do celu, koszty podróży, bezpieczeństwo, nawyk [Bandrowska-Kaim i in. 2018].

Według Pucher i in. [2006] do ograniczenia użytkowania pojazdów silnikowych $\mathrm{w}$ zatłoczonych centrach miast może przyczynić się poznanie motywacji podróżujących, jak również rozbudowa i poprawa stanu transportu publicznego oraz dostosowanie go do obecnych potrzeb. Ponadto zmiana wysokoemisyjnych środków transportu na rzecz rozwoju ekologicznych środków transportu - samochodów napędzanych ogniwami paliwowymi czy kolejek magnetycznych - mo- 
że przyczynić się do ograniczenia, a nawet do wyeliminowania emisji szkodliwych substancji [Ausubel i in. 1998].

Prowadzenie badań dotyczących zachowań komunikacyjnych mieszkańców miasta $\mathrm{w}$ zależności od celu podróży jest szczególnie ważne i powinno być poparte analizami zachowań i preferencji komunikacyjnych mieszkańców, ponieważ efektywne zarządzanie transportem (zbiorowym i indywidualnym) w miastach może ograniczyć szkodliwy wpływ transportu samochodowego na środowisko naturalne. $Z$ kolei lepsze dostosowanie oferty transportowej miasta do użytkowników poprzez budowanie zrównoważonej strategii rozwoju transportu miejskiego przyczyni się do zmniejszenia emisji $\mathrm{CO}_{2}$.

\section{Cel i metodyka badań}

Głównym celem tego artykułu było określenie korzyści środowiskowych wynikających z wyboru środka transportu oraz diagnoza preferencji komunikacyjnych mieszkańców Lublina w zależności od celu podróży. Ponadto autorzy artykułu podjęli próbę określenia wpływu danego środka transportu na środowisko naturalne.

W celu określenia preferencji komunikacyjnych, czynników determinujących wybór środka transportu, a także dokonania oceny ekologicznej świadomości mieszkańców przeprowadzono badanie ankietowe. Wykorzystana metoda badawcza pozwoliła $\mathrm{w}$ prosty sposób uzyskać wiarygodny zbiór danych oraz przeprowadzić wybrane analizy. Ankietowani reprezentowali różne grupy wiekowe, poziom wykształcenia, zawód oraz miejsce zamieszkania (różne dzielnice Lublina). Zróżnicowanie grupy ankietowanych pozwoliło wiarygodnie określić preferencje komunikacyjne, czynniki wyboru środka komunikacji oraz świadomość ekologiczną mieszkańców Lublina.

Badanie zostało przeprowadzone na terenie miasteczka akademickiego w Lublinie na przełomie stycznia i lutego $2020 \mathrm{r}$. W badaniu wykorzystano kwestionariusz ankiety, zawierający 12 pytań zamkniętych oraz 2 pytania otwarte. W celu określenia preferencji komunikacyjnych i czynników wyboru środków transportu wykorzystano 8 zamkniętych pytań. Respondenci mieli określić, czy posiadają samochód do codziennej dyspozycji, w jakich kierunkach najczęściej się przemieszczają, na jaki środek transportu decydują się podczas wyboru konkretnego celu podróży, co jest głównym czynnikiem determinującym ten wybór oraz jak oceniają komunikację miejską na terenie miasta Lublin. Natomiast do określenia ekologicznej świadomości wykorzystano 2 pytania. Wprowadzenie do kwestionariusza pytań dotyczących ekologicznej świadomości miało na celu określenie poziomu wiedzy mieszkańców na temat ekologicznych alternatyw dla preferowanego transportu oraz czynników mających wpływ na zmianę ich nawyków komunikacyjnych. 


\section{Wyniki badań}

W badaniu udział wzięło 150 osób, z czego ponad połowę (62\%) stanowiły kobiety (rys. 1). W strukturze wieku dominowały osoby w wieku 20-27 (66\%), osoby w wieku 28-49 stanowiły $21 \%$ ankietowanych, $6 \%$ to osoby do 19 roku życia, osoby w przedziale 50-64 (4\%), natomiast osoby powyżej 64 roku życia stanowiły zaledwie $3 \%$ wszystkich ankietowanych (rys. 2). Ponad połowa ankietowanych zadeklarowała wyższe wykształcenie (55\%), 26\% ankietowanych zadeklarowało, że posiada wykształcenie średnie ogólnokształcące, $15 \%$ policealne oraz średnie zawodowe, natomiast $4 \%$ gimnazjalne, podstawowe i niższe (rys. 3 ).

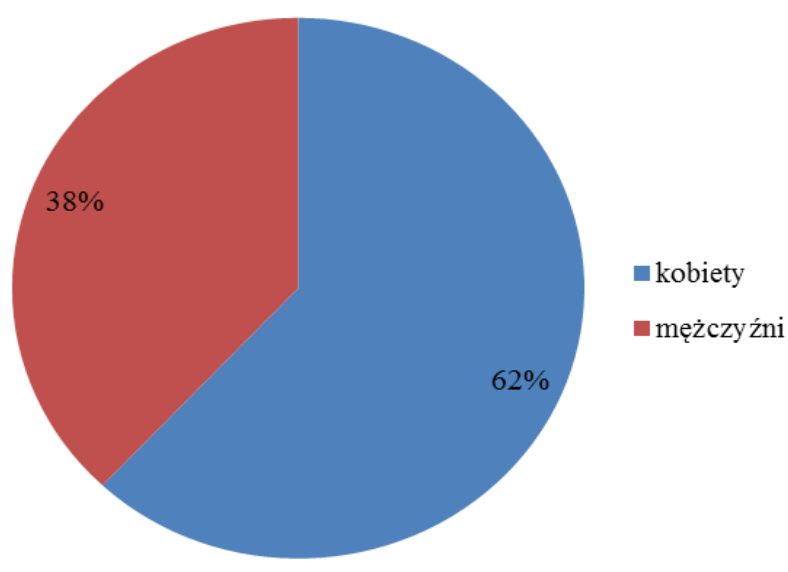

Rys. 1. Płeć respondentów

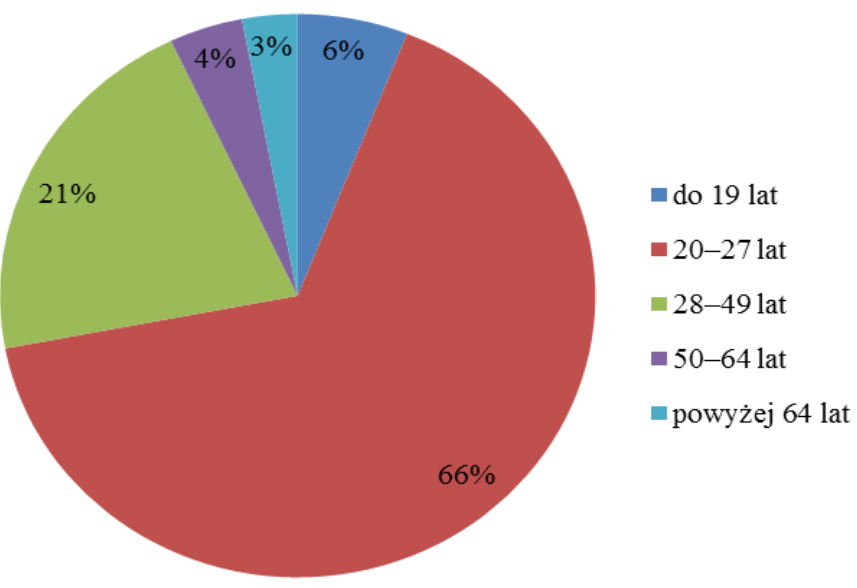

Rys. 2. Wiek respondentów 


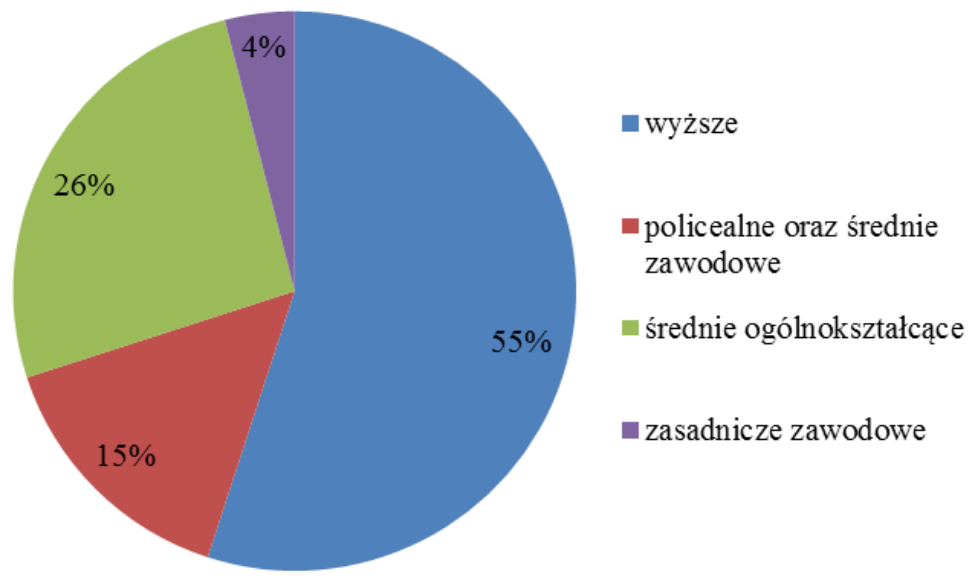

Rys. 3. Wykształcenie respondentów

\section{Kierunki podróży}

Z przeprowadzonych badań wynika, że mieszkańcy Lublina najczęściej wybierają do codziennych podróży samochód (51\% ankietowanych), 23\% respondentów wskazało na podróże autobusem (z uwzględnieniem komunikacji miejskiej), 11\% badanych zadeklarowało, że przemieszcza się rowerem, 9\% pieszo, $4 \%$ pociągiem. Hulajnogę jako środek transportu do codziennych podróży wykorzystuje zaledwie $2 \%$ badanych (rys. 4). Powyższe wyniki wskazują na to, że

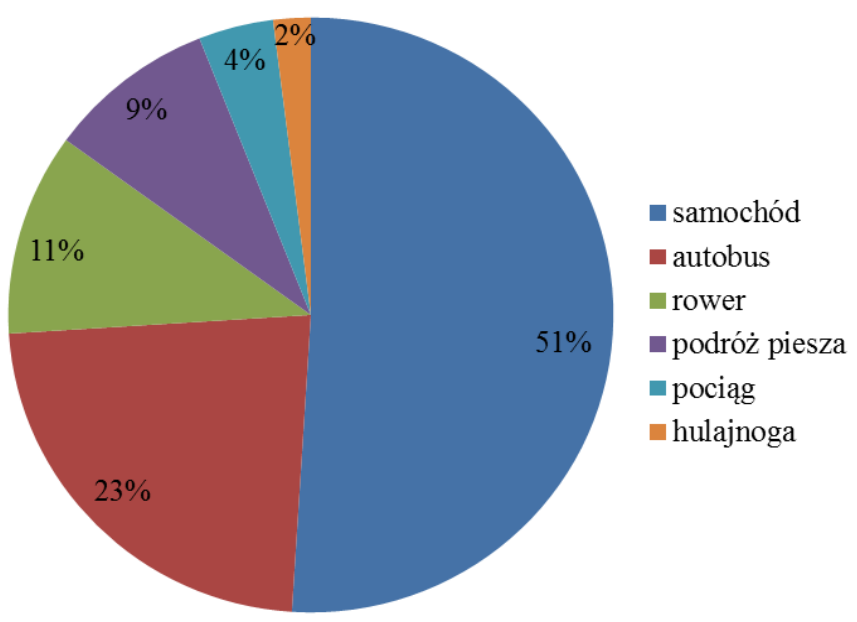

Rys. 4. Środek transportu wykorzystywany do codziennej podróży 


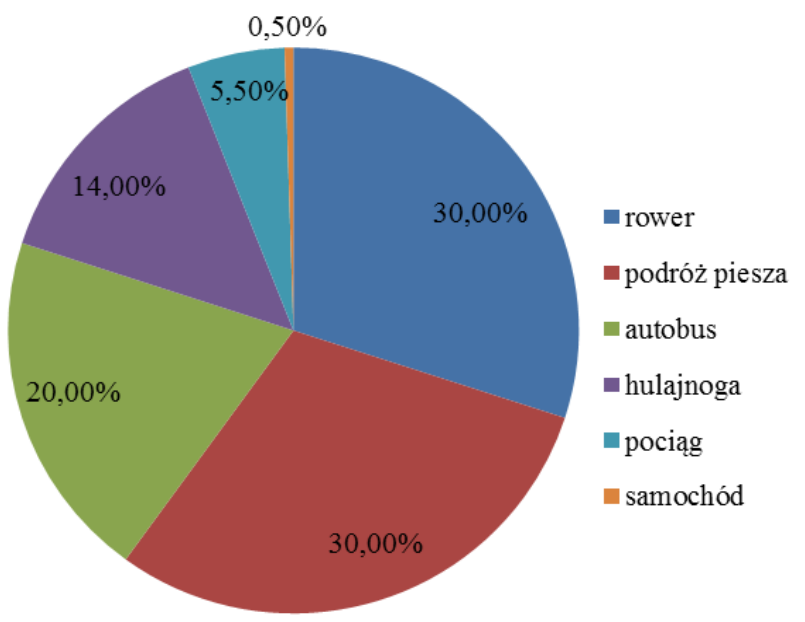

Rys. 5. Ekologiczny środek transportu

mieszkańcy Lublina najczęściej wybierają najmniej ekologiczne środki transportu (samochód i autobus). Respondenci zostali poproszeni o wskazanie, który z podanych środków transportu jest dla nich najbardziej ekologiczny. Najwięcej wskazań uzyskał rower, a także przemieszczanie się pieszo (odpowiednio po $30 \%$ odpowiedzi), co potwierdza wiedzę ankietowanych na temat najbardziej ekologicznych metody transportu $\mathrm{w}$ miastach. Transport zbiorowy $\mathrm{w}$ postaci autobusów wskazało $20 \%$ ankietowanych, hulajnogę $14 \%$, zaś pociąg $5,5 \%$ respondentów. Natomiast samochód został uznany za najmniej ekologiczny środek transportu (0,5\% wskazań) (rys. 5).

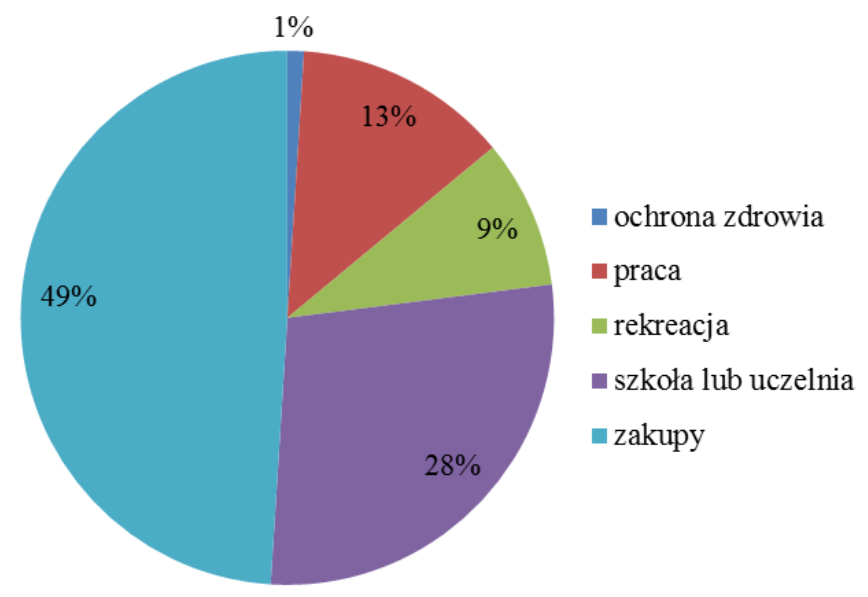

Rys. 6. Główne kierunki pieszej podróży 
Analiza głównych kierunków podróży respondentów pozwoliła na określenie zależności pomiędzy kierunkiem podróży a wyborem konkretnego środka transportu. Ankietowani wskazywali, że najczęściej przemieszczają się pieszo w celu zrobienia zakupów (49\%) oraz wyjścia do szkoły lub na uczelnię (28\%). Jedynie $13 \%$ ankietowanych zadeklarowała, że drogę do pracy pokonuje pieszo. W celach rekreacyjnych ze spaceru korzysta 9\% ankietowanych. Spacer jako środek przemieszczania w celu załatwienia spraw związanych $\mathrm{z}$ ochroną zdrowia wybrał tylko $1 \%$ ankietowanych (rys. 6). Rower, mimo iż został wskazany przez respondentów jako jeden z najbardziej ekologicznych środków transportu, wybierany jest jedynie przez $9 \%$ ankietowanych. Najwięcej ankietowanych z roweru jako środka transportu korzysta w celach rekreacyjnych (35\% wskazań) w dojazdach do pracy i szkoły (odpowiednio po 25 i $20 \%$ wskazań). Rower jako środek transportu na zakupy wybierało $16 \%$ ankietowanych, zaś $4 \%$ ankietowanych wykorzystuje rower jako środek transportu w celu załatwienia spraw urzędowych (rys. 7). Zdecydowana większość ankietowanych (98\%) z hulajnogi jako

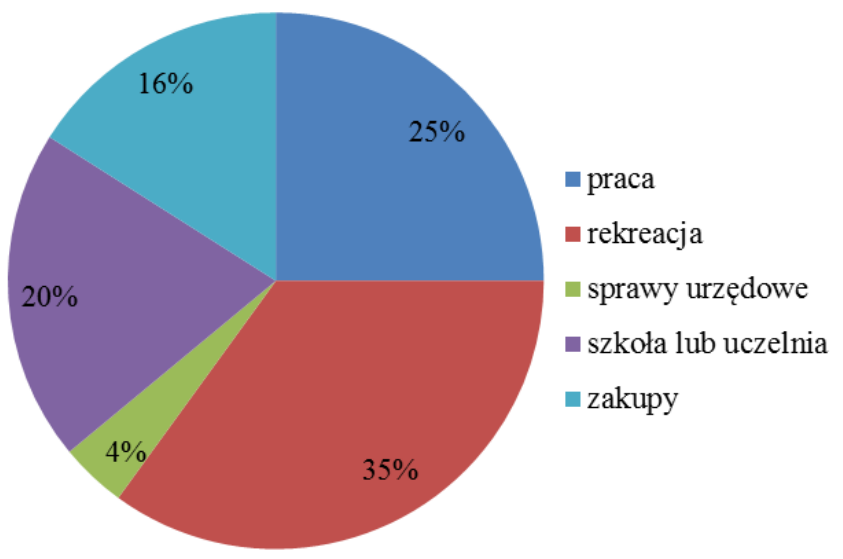

Rys. 7. Główne kierunki podróży rowerem

środka transportu korzysta w celach rekreacyjnych, pozostałe $2 \%$ ankietowanych wykorzystuje hulajnoge jako środek transportu do szkoły i w celu załatwienia spraw urzędowych (rys. 8). Z przeprowadzonych badań wynika, że ponad połowa ankietowanych (51\%) posiada własny samochód do dyspozycji każdego dnia, a najpopularniejsze kierunki podróży autem to: zakupy, praca oraz szkoła (odpowiednio 38, 23 i 15\% wskazań). Auto jako środek transportu do miejsca rekreacji wykorzystuje $14 \%$ ankietowanych, a w sprawach urzędowych $10 \%$. Pozostałe osoby $(1 \%) \mathrm{z}$ auta korzystają w celu dotarcia do instytucji ochrony zdrowia (rys. 9). 


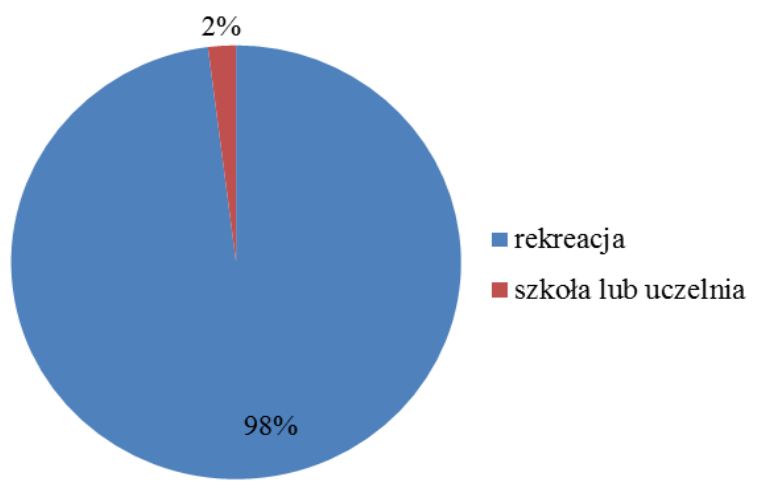

Rys. 8. Główne kierunki podróży hulajnogą

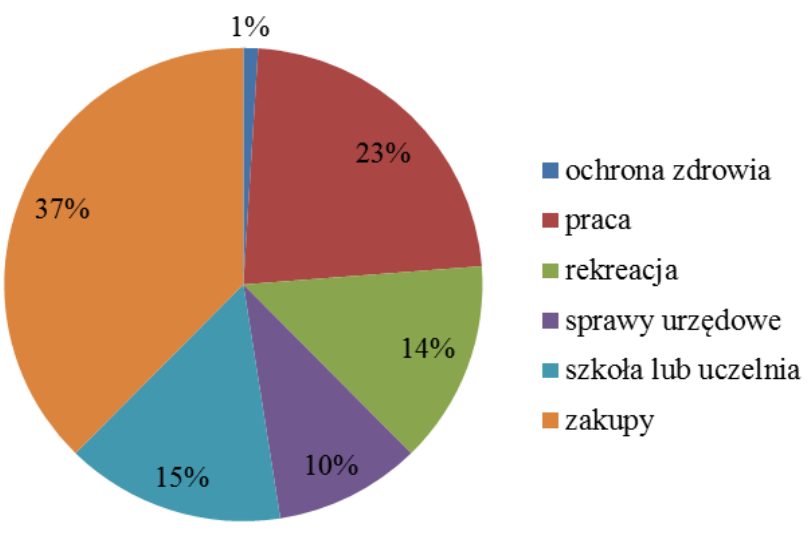

Rys. 9. Główne kierunki podróży samochodem

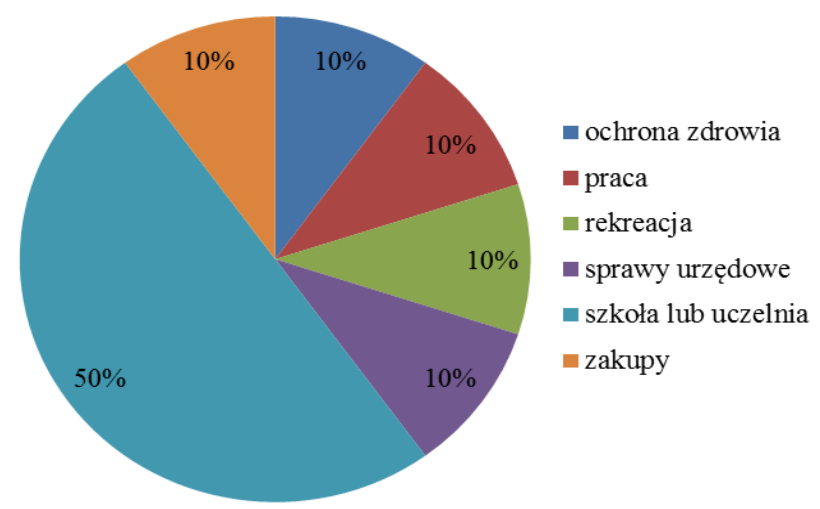

Rys. 10. Główne kierunki podróży komunikacją miejską 


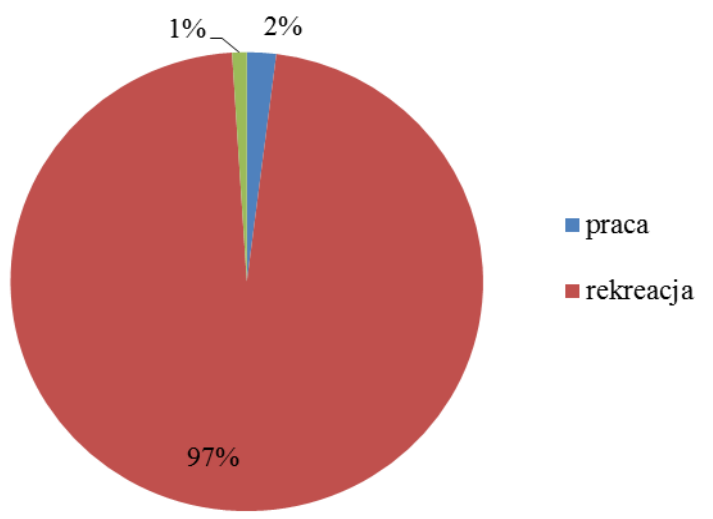

Rys. 11. Główne kierunki podróży pociągiem

Badania wykazały, że połowa ankietowanych wybiera komunikację miejską jako środek transportu do szkoły (50\%). Pozostałe osoby korzystają z komunikacji miejskiej w drodze do pracy, instytucji ochrony zdrowia jak również na zakupy oraz w celach rekreacyjnych i sprawach urzędowych (odpowiednio po 10\% wskazań) (rys. 10).

Badania wykazały również, że 4\% ankietowanych przemieszcza się codziennie wykorzystując do tego pociąg. Celem ich podróży są najczęściej wyjazdy rekreacyjne (97\%), a także dojazd do pracy i na uczelnię (odpowiednio 2 i 1\% wskazań) (rys. 11).

\section{Cechy determinujące wybór środka transportu}

Respondenci w ankiecie zostali poproszeni o wskazanie cech, które według nich są najbardziej istotne podczas wyboru danego środka transportu. Wśród badanych cech znalazły się: wpływ środka transportu na środowisko, bezpośredniość (oznaczająca możliwość przejazdu do celu bez konieczności przesiadania się), częstotliwość kursowania (odstęp między odjazdami i przyjazdami środka transportu), dostępność środka transportu (odległość lokalizacji środka transportu od miejsca zamieszkania), rytmiczność (rozumiana jako równomierny odstęp między kursami w danym kierunku), dostęp do informacji, bezpieczeństwo, dostosowanie środka transportu do potrzeb osób niepełnosprawnych, jak również niezawodność, koszt podróży, punktualność, czas przejazdu i wygoda środka transportu. 


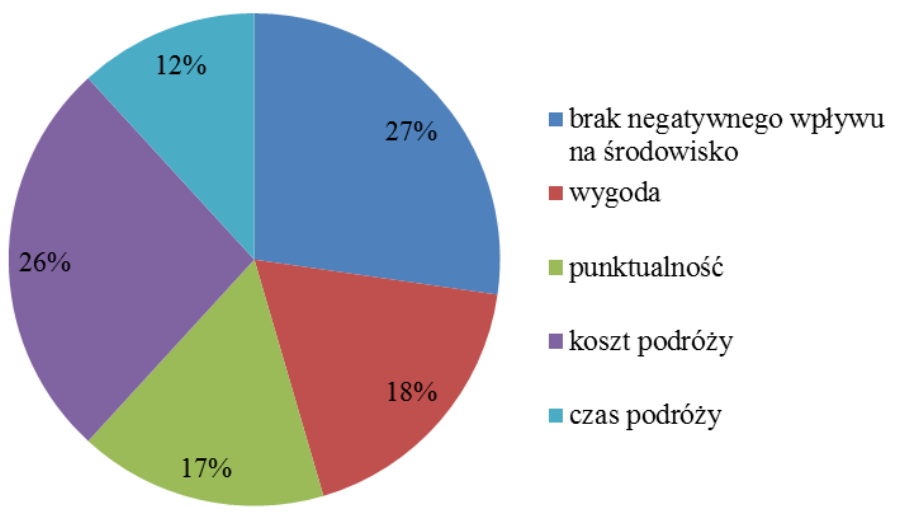

Rys. 12. Determinujące cechy wyboru podróży rowerem

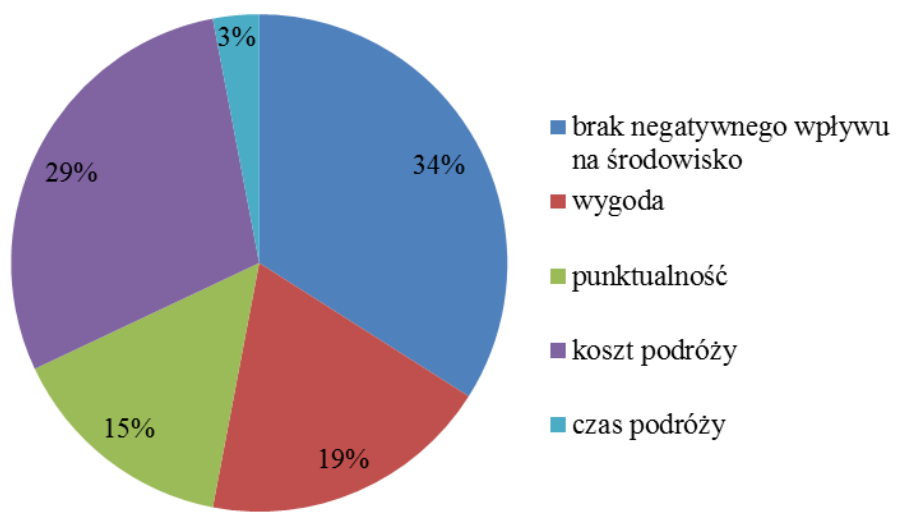

Rys. 13. Determinujące cechy wyboru pieszej podróży

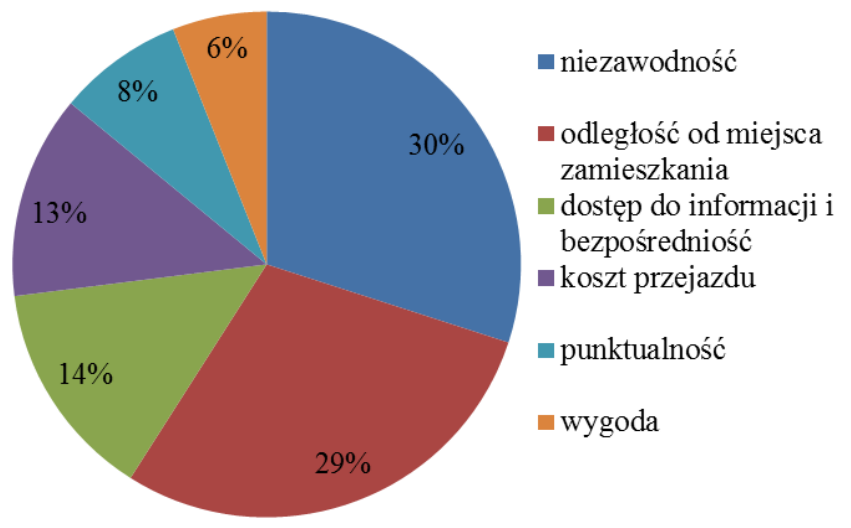

Rys. 14. Determinujące cechy wyboru podróży hulajnogą 


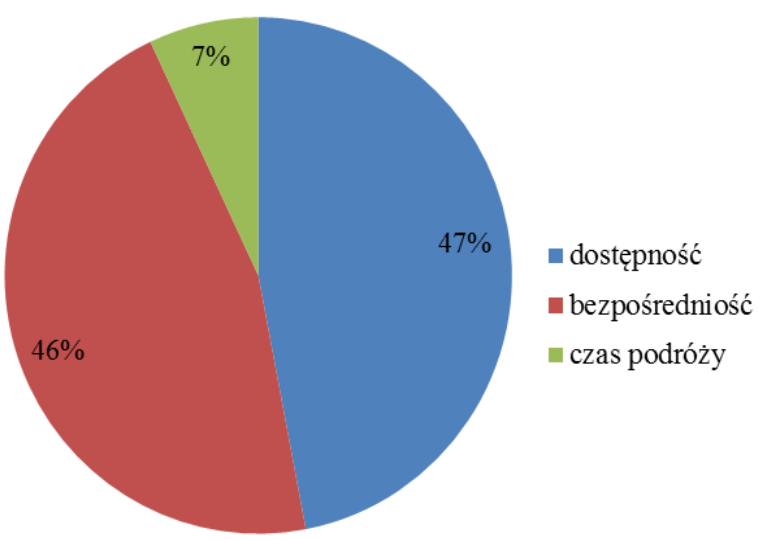

Rys. 15. Determinujące cechy wyboru podróży samochodem

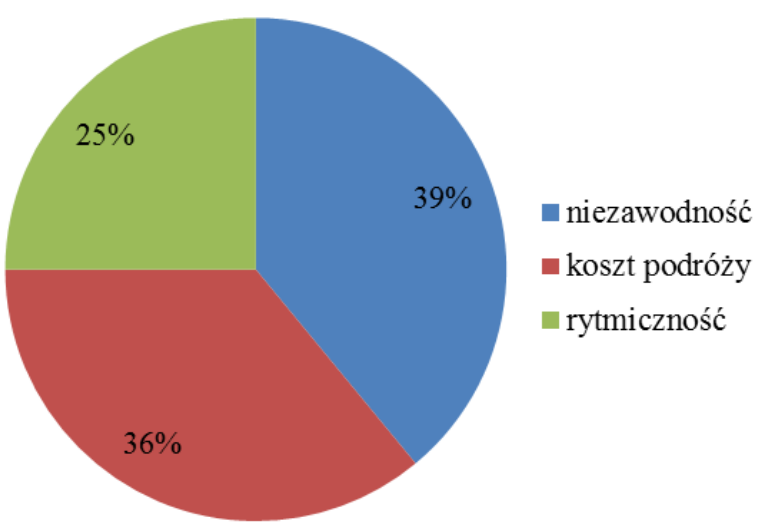

Rys. 16. Determinujące cechy wyboru podróży komunikacją miejską

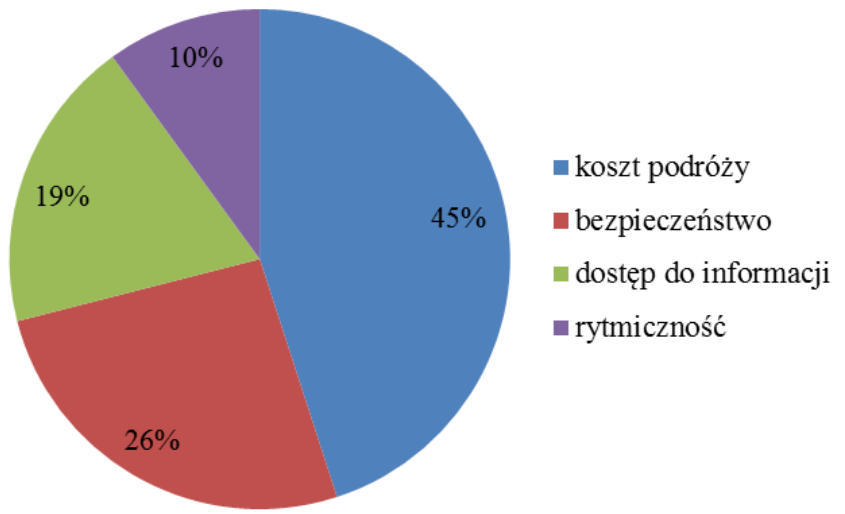

Rys. 17. Determinujące cechy wyboru podróży pociągiem 
Głównym powodem wyboru roweru (rys. 12) i przemieszczania się pieszo (rys. 13) przez ankietowanych był brak negatywnego wpływu tych środków transportu na środowisko (odpowiednio 30 i 34\% wskazań), wygoda (odpowiednio 20 i 19\% wskazań), punktualność (odpowiednio 18 i 15\% wskazań), jak również koszt podróży (odpowiednio po $29 \%$ wskazań) i czas podróży (odpowiednio 13 i 3\% wskazań). Hulajnogę jako środek transportu wybierano głównie ze względu na niezawodność (30\%), odległość od miejsca zamieszkania (29\%), dostęp do informacji i bezpośredniość (po 14\% wskazań) oraz koszt przejazdu (13\%) (rys. 14).Wybór samochodu determinowała w największym stopniu dostępność środka transportu (47\% wskazań), a także jego bezpośredniość (46\%) i czas podróży (7\%) (rys. 15). W przypadku komunikacji miejskiej najważniejszą cechą okazała się niezawodność (39\%), koszty podróży (36\%) oraz rytmiczność (25\%) (wyk. 16). Za najważniejszą cechę wpływającą na wybór pociągu jako środka transportu ankietowani uznali koszty podróży (45\%), bezpieczeństwo (26\%), dostęp do informacji (19\%) i rytmiczność (10\%) (rys. 17).

W pytaniu otwartym zapytano również użytkowników samochodów, co skłoniłoby ich do zmiany nawyków komunikacyjnych na bardziej przyjazne środowisku. Jedynie 30\% kierowców odpowiedziało na to pytanie i jako powód zmiany środka transportu wskazali darmowy transport publiczny (31\%), zniżki na komunikację zbiorową po okazaniu dowodu rejestracyjnego (28\%), wyższe stawki za parking w centrum miasta $(27 \%)$, rozbudowę ścieżek rowerowych (11\%) oraz zbudowanie bezkolizyjnej kolejki szynowej nad ziemią (3\%) (rys. 18).

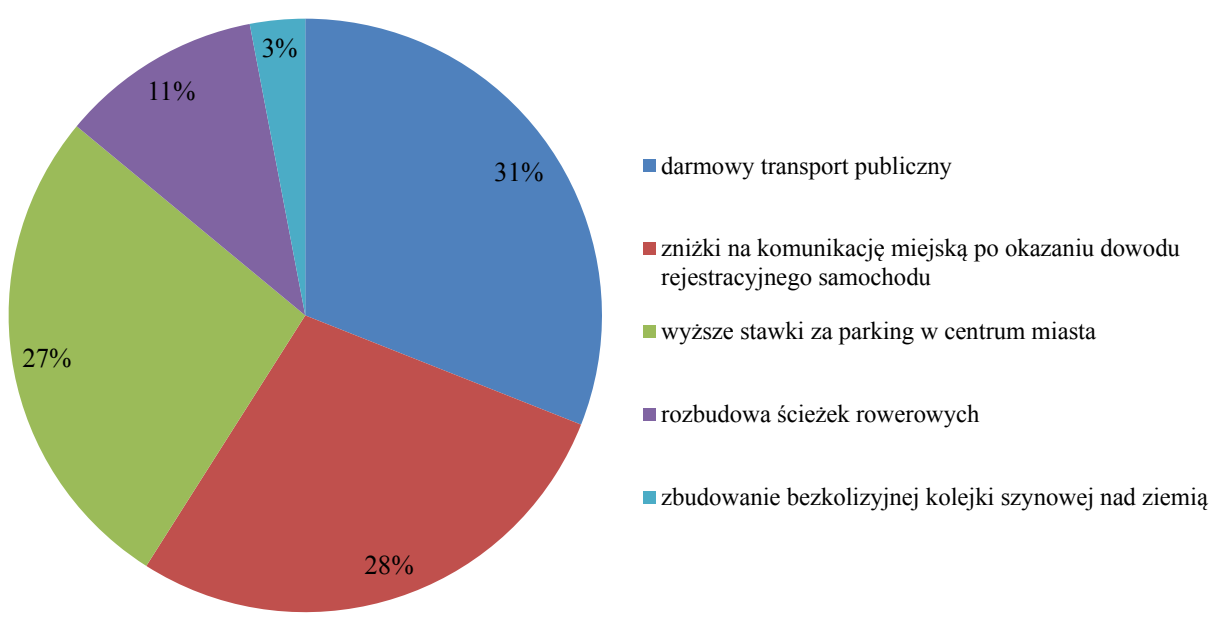

Rys. 18. Motywacje zmiany nawyków komunikacyjnych poruszających się samochodem

Analiza cech determinujących wybór środka transportu wykazała, że główną determinantą wyboru transportu indywidualnego jest jego dostępność oraz bezpośredniość, ale po wprowadzeniu odpowiednich udogodnień kierow- 
cy zdecydowaliby się na zmianę nawyków i korzystanie $\mathrm{z}$ transportu zbiorowego a nawet roweru.

\section{Komunikacja miejska}

Kolejnym etapem badań była ocena preferencji respondentów w zakresie korzystania wyłącznie z komunikacji miejskiej realizowanej na terenie miasta Lublin. W badaniu pytano ankietowanych o to, jak oceniają komunikację miejską ze względu na: bezpośredniość połączeń, częstotliwość kursowania autobusów, dostępność, koszty podróży, niezawodność, punktualność, dostęp do informacji, dostosowanie do potrzeb osób niepełnosprawnych, czas podróży, wygodę oraz rytmiczność kursów. Ocenę komunikacji wykonano w 5-stopniowej skali (gdzie 5 - bardzo dobrze, 4 - dobrze, 3 - dostatecznie, 2 - słabo, a 1 - bardzo słabo).

Żadna $\mathrm{z}$ badanych cech nie została oceniona bardzo dobrze, dostatecznie i bardzo słabo. Dobrze oceniono bezpośredniość połączeń, częstotliwość kursowania autobusów, ich dostępność, koszty podróży, niezawodność, punktualność, dostęp do informacji oraz dostosowanie do potrzeb osób niepełnosprawnych. Natomiast słabo oceniono czas podróży, wygodę oraz rytmiczność kursów. Respondenci zapytani o podanie odpowiedzi, które $\mathrm{z}$ ww. cech powinny zostać poprawione w celu zachęcenia mieszkańców Lublina do korzystania $\mathrm{z}$ transportu zbiorowego, wskazali: bezpośredniość połączeń autobusowych (47\% wskazań), częstotliwość kursowania autobusów (45\% wskazań) oraz punktualność (43\% wskazań). Cechami, które zostały najrzadziej wymienione przez respondentów były: bezpieczeństwo (17\%), dostęp do informacji o kursach autobusów (13\%) oraz dostosowanie pojazdów do osób niepełnosprawnych (10,6\% wskazań). Analiza wyników wskazuje, że sprawna i dostępna komunikacja miejska może stać się skuteczną alternatywą dla korzystania z samochodów indywidualnych $\mathrm{w}$ mieście, co w konsekwencji może wpłynąć na poprawę jakości życia w mieście.

\section{Dyskusja}

Wyniki przeprowadzonej ankiety pozwalają stwierdzić, że zachowania komunikacyjne mieszkańców Lublina uzależnione są głównie od celu podróży, jak również od warunków, jakie oferują poszczególne środki transportu. Mimo że większość respondentów na co dzień po Lublinie porusza się samochodem, to $30 \% \mathrm{z}$ nich jest w stanie zmienić swoje preferencje komunikacyjne na bardziej przyjazne środowisku pod warunkiem zastosowania pewnych odgórnych udogodnień. Do podobnych wniosków dochodzi Wyszomirska-Góra [2013] w swoich badaniach dotyczących psychologicznych aspektów wyboru środka transportu. Zauważyła ona, że ludzie skłonni są zrezygnować z preferowanego środka transportu, gdy zauważą, że ich proekologiczne postępowanie zyska aprobatę społeczności. 
Z przeprowadzonych na terenie miasta Lublin badań jednoznacznie wynika, że głównymi determinantami wyboru indywidualnego środka transportu są dostępność oraz bezpośredniość. Natomiast zbiorowego - niezawodność i koszt podróży, zaś ekologicznego (rower, podróż piesza) - wpływ na jakość środowiska naturalnego oraz niski koszt. Podobne wyniki uzyskali Stoeck i Gołębiewski [2011], którzy w swoich baniach zauważyli, że głównymi determinantami wyboru środka transportu są: częstotliwość, punktualność, dostępność, komfort, koszt podróży oraz bezpośredniość. Zauważyli oni również, że odległość pomiędzy miejscem zamieszkania a miejscem pracy czy nauki oraz dostępność środka transportu w tych miejscach znacząco różnicuje wybór środka transportu. Również Kuźnar i Wyraz [2015] wysnuwają podobne wnioski, że na wybór środka transportu ma wpływ dostępność, ilość i jakość infrastruktury transportowej. Natomiast Brzeziński i Rezowow [2007] w swoich badaniach podkreślają, że jeżeli transport publiczny będzie bardziej konkurencyjny z samochodem osobowym to wpłynie to na ograniczenie negatywnych skutków środowiskowych oraz podwyższy jakość przestrzeni miejskiej.

Wyniki te potwierdzają, że odpowiednia polityka miasta oraz wprowadzenie większych korzyści dla osób korzystających z transportu publicznego i ekologicznego może pozytywnie wpłynąć na zmniejszenie indywidualnego ruchu kołowego w mieście. Preferencje transportowe mieszkańców są zmienne w czasie, związane jest to z panującymi warunkami atmosferycznymi, ale także z zamożnością mieszkańców, dlatego tak ważne jest stałe monitorowanie i prowadzenie badań na ten temat. Potwierdzają to Mikulska i Starowicz [2015], które zwracają uwagę, że racjonalne podejmowanie decyzji związanych z udoskonaleniem i rozwojem systemu komunikacyjnego możliwe jest dzięki aktualnym danym dotyczącym preferencji komunikacyjnych. Również Konarski i Wyszomirski [2015] zauważyli, że należy kształtować ofertę przewozową zgodnie z preferencjami mieszkańców oraz użytkowników danego terenu, by w ten sposób stymulować rozwój proekologicznych nawyków komunikacyjnych w mieście.

Należy pamiętać, że mechaniczne środki transportu mają ogromny wpływ na zmiany klimatyczne. Poprawienie wydajności systemu transportowego może przyczynić się do zmniejszenia emisji szkodliwych substancji i zatorów komunikacyjnych $\mathrm{w}$ mieście. Ograniczenie wzrostu przejazdów samochodowych możliwe będzie dzięki przekierowaniu podróżnych na bardziej wydajne środki transportu, zwiększeniu wykorzystania miejsc w samochodzie oraz ograniczeniu podróży w pojedynkę. Zastosowanie nowych technologii i wprowadzenie nowoczesnych systemów transportowych przyczyni się również do zmniejszenia negatywnego wpływu na środowisko. Jedynym z podstawowych rozwiązań może być zmiana środka transportu na bardziej ekologiczny, taki jak: rower, podróż piesza, komunikacja zbiorowa czy też pociąg [Boening 2000, Peters i Schouten 2006, Tokarczyk 2012]. Jednak takie zmiany wymagają dostosowania dostępności oraz jakości środków transportu do potrzeb potencjalnego użytkownika, co tylko potwierdza zasadność realizowanych badań dotyczących preferencji trans- 
portowych. Rozpoznanie najważniejszych preferencji może pozwolić na opracowanie $\mathrm{w}$ strategiach transportowych proekologicznych rozwiązań, które zmniejszyłyby zanieczyszczenie powietrza $\mathrm{w}$ mieście.

\section{Wnioski}

Dokonana analiza preferencji komunikacyjnych mieszkańców Lublina wykazała, że zachowania komunikacyjne mieszkańców uzależnione są w dużej mierze od celu podróży oraz konkretnych korzyści, jakie niesie ze sobą podróż różnymi środkami transportu. Głównym powodem wyboru roweru jako środka transportu przez ankietowanych jest duża świadomość ekologiczna. Rower, mimo iż jest uważany za jeden z najbardziej ekologicznych środków transportu, wykorzystywany jest przez ankietowanych głównie do rekreacji. Transport zbiorowy wybierany jest głównie ze względu na jego niezawodność i koszt podróży. Niezawodna i tania komunikacja miejska może stać się alternatywą dla indywidualnych środków transportu, co w konsekwencji przyczyni się do poprawy jakości środowiska naturalnego i życia w mieście. Stosowanie zachęt (np. darmowy transport publiczny, zniżki na komunikację miejską po okazaniu dowodu rejestracyjnego samochodu) i propagowanie ekologicznych środków transportu może przyczynić się do ograniczenia emisji szkodliwych substancji ze spalin samochodowych. Z kolei wzrost świadomości ekologicznej mieszkańców oraz odpowiednia polityka władz miasta Lublina mogłaby pozytywnie wpłynąć na ograniczenie emisji spalin.

\section{Bibliografia}

Ausubel J., Marchetti C., Meyer P., 1998. Toward green mobility: The evolution of transport. Eur. Rev. 6(2), 137-156. https://doi.org/10.1017/S1062798700003185

Bandrowska-Kaim A., Dębowska-Mróz M., Repeć R., 2018. Ocena zachowań komunikacyjnych uczniów szkół średnich i studentów w Radomiu, Instytut Naukowo-Wydawniczy Spatium, Radom.

Boening D.W., 2000. Ecological effects, transport, and fate of mercury: a general review. Chemosphere 40(12), 1335-1351. https://doi.org/10.1016/S0045-6535(99)00283-0

Brzeziński A., Rezowow M., 2007. Zrównoważony transport - ekologiczne rozwiązania transportowe. http://www.transeko.pl/publikacje.html [dostęp: 08.04.2020].

Curtis C., Perkins T., 2006. Travel Behaviour: A review of recent literature. Curtin University Working Paper, Perth.

Dudziak A., Stoma M., Rydzak L., Rodzeń A., 2018. Wybór środka komunikacji w opinii mieszkańców Lubelszczyzny. Politechnika Śląska, Gliwice.

Dzikuć M., Adamczyk J., Piwowar A. (2017). Problems associated with the emissions limitations from road transport in the Lubuskie Province (Poland). Atmosph. Environ. 160, 1-8. https://doi.org/10.1016/j.atmosenv.2017.04.011

Goldman T., Gordham R., 2006. Sustainable urban transport: Four innovative directions. Technol. Soc. 28, 261-273. https://doi.org/10.1016/j.techsoc.2005.10.007 
Konarski M., Wyszomirski O., 2015. Preferencje i zachowania komunikacyjne uczniów liceów ogólnokształcących w Gdyni i Sopocie, Instytut Naukowo-Wydawniczy „Spatium” sp. z o.o., Radom.

Kuźnar M., Wyraz E., 2015. Międzymiastowe środki transportu wykorzystywane przez studentów Politechniki Krakowskiej. Logistyka 3, 2706-2714.

Marszałek S., 2001. Ekonomika, organizacja i zarządzanie w transporcie. Śląska Wyższa Szkoła Zarządzania, Katowice.

Mikulska A., Starowicz W., 2015. Analiza preferencji i satysfakcji pasażerów transportu publicznego w Kielcach. Stowarzyszenie Inżynierów i Techników Komunikacji Rzeczpospolitej Polskiej, Warszawa.

Peters P., Schouten F., 2006. Reducing the Ecological Footprint of Inbound Tourism and Transport to Amsterdam. Journal of Sustainable Tourism 14(2).

Pucher J., Peng Z. R., Mittal N., Zhu Y., Korattyswaroopam N., 2006. Urban Transport Trends and Policies in China andIndia: Impacts of Rapid Economic Growth, Transport Reviews, vol. 27(4), 379-410. https://doi.org/10.1080/01441640601089988

Sierpiński G., 2012. Zachowania komunikacyjne osób podróżujących a wybór środka transportu w mieście. Politechnika Warszawska, Warszawa.

Stoeck T., Gołębiewski W., 2011. Badanie preferencji komunikacyjnych oraz ocena lokalnego transportu zbiorowego w szczecinie w aspekcie jego ekologiczności i ekonomiczności, Instytut Naukowo-Wydawniczy „Spatium”, Radom.

Tłuczak A., 2013. Determinanty wyboru środka komunikacji miejskiej na przykładzie Opola. Uniwersytet Opolski, Opole.

Tokarczyk E., 2012. Wiedza i zachowania kierowców a ochrona środowiska. Wyd. ITS, Warszawa.

Woodcock J., Edwards P., Tonne C., Armstrong B., Ashiru O., Banister D., 2009. Public health benefits of strategies to reduce greenhouse-gas emissions: urban land transport. Lancet, 374.

Wyszomirska-Góra M., 2013. Psychologiczne determinanty wyboru środka transportu w codziennych podróżach miejskich. Stowarzyszenie Inżynierów i Techników Komunikacji Rzeczpospolitej Polskiej, Warszawa.

Wyszomirski O. (red.), 2008. Transport miejski. Ekonomika i organizacja. Wydawnictwo Uniwersytetu Gdańskiego, Gdańsk. 
Monika Zająkała@1

\title{
Przemiany polskiego zielarstwa w ostatnim stuleciu
}

Evolution in Polish herbalism in the last century

\begin{abstract}
Wstęp
W ostatnim stuleciu doszło do wielu przemian gospodarczych, ekonomicznych i politycznych w sektorze zielarstwa. Wykorzystywanie ziół jako przypraw, roślin ozdobnych oraz naturalnych farmaceutyków $\mathrm{z}$ każdym rokiem rośnie, co szczególnie obserwowane jest w krajach rozwijających się. Sytuacja ta wynika ze zmian nawyków żywieniowych oraz coraz większej świadomości konsumentów na temat pozytywnego działania substancji czynnych pochodzenia roślinnego [Newerli-Guz 2015]. Rosnący popyt na surowce zielarskie wymusza zmiany, na co uwagę zwraca nauka i gospodarka. Szczególnie ważne z perspektywy uprawy i jej ekonomii, przetwórstwa ziół oraz przemian gospodarczych na rynkach zbytu były podejmowane przez polskich lekarzy oraz farmaceutów działania promujące zielarstwo, szczególnie wydawanie specjalistycznych czasopism.

Kluczową rolę odegrały również instytucje wspierające zielarzy i przetwórców: Towarzystwo Popierania Produkcji Roślin Lekarskich (TPPRL), Polski Komitet Zielarski (PKZ), Polski Związek Zielarski (PZZ), Państwowy Instytut Naukowy Leczniczych Surowców Roślinnych (PINLSR), Zjednoczenie Przemysłu Zielarskiego „Herbapol” oraz Instytut Włókien Naturalnych i Roślin Zielarskich (IWNiRZ). Dzięki pracy członków tych organizacji zaobserwowano zwiększenie zainteresowania uprawą ziół oraz znaczący postęp hodowlany. Ważny wpływ na kształtowanie się zielarstwa miały także przemiany ustrojowe, które wymusiły prywatyzację państwowych zakładów przetwórczych „Herbapol” [Magowska 2009]. Odzyskanie przez Polskę niepodległości spowodowało liczne transformacje w aspekcie możliwości handlu międzynarodowego polskimi surowcami zielarskimi [Mikołajczyk-Grzelak 2008]. Obecnie zielarstwo staje się coraz popularniejszym kierunkiem produkcji rolniczej i jest szansą szczególnie dla gospodarstw o niewielkiej powierzchni. Pomimo zmniejszenia ogólnego areału uprawy ziół w naszym kraju produkcja utrzymuje się na zbliżonym poziomie dzięki nowoczesnej agrotechnice i regionalizacji produkcji [Olewnicki i in. 2015].
\end{abstract}

\footnotetext{
${ }^{1}$ Uniwersytet Technologiczno-Przyrodniczy w Bydgoszczy, Wydział Rolnictwa i Biotechnologii, monika_zareba@interia.pl
} 
Celem pracy było przedstawienie najważniejszych czynników, które miały wpływ na przemiany zielarstwa $\mathrm{w}$ ostatnim stuleciu oraz zaprezentowanie pionierów upowszechniania uprawy ziół na ziemiach polskich na podstawie przeglądu istniejącego stanu wiedzy na ten temat.

\section{Przemiany polskiego zielarstwa}

Za kolebkę zielarstwa w Polsce uznaje się klasztory działające od czasów starożytnych, których działalność polegała m.in. na produkcji ziołowych preparatów leczniczych i służbie osobom chorym. Prowadzenie domowych ziołowych apteczek było dobrze znanym zwyczajem wielu Polaków. Z czasem zaczęto odkrywać potencjał zielarstwa jako szansy dla rolników na główny kierunek produkcji w gospodarstwach i farmaceutów, którzy w ziołach upatrywali antidotum na wiele schorzeń. Upowszechnianie uprawy i przerobu ziół było jednym z zadań władz państwa polskiego po odzyskaniu niepodległości. Początki rządowej ochrony zielarstwa sięgają utworzonego w listopadzie 1918 r. referatu roślin lekarskich oraz Stacji Doświadczalnej w Dąbrowie Opoczyńskiej. Niestety ze względów ekonomicznych po kilku latach zawieszono działalność stacji. Ministerstwo Rolnictwa dostrzegało jednak potencjał w zielarstwie. Uprawą ziół szczególnie zainteresowani byli rolnicy ze wschodniej części kraju, w której panowała duża bieda. Ludzie ci $\mathrm{w}$ ziołach upatrywali szansę poprawy statusu materialnego [Magowska 2009].

W grudniu 1926 r. powstało Towarzystwo Popierania Produkcji Roślin Lekarskich (TPPRL), do którego należeli naukowcy, lekarze, farmaceuci oraz rolnicy. Stowarzyszenie wydawało czasopismo „Rośliny Lecznicze i Przemysłowe”, skierowane głównie do praktyków zielarstwa. Wiosną 1930 r. zawiązano Polski Komitet Zielarski (PKZ), co było bezpośrednią przyczyną wygaśnięcia działalności TPPRL. Początkowo PKZ liczył jedynie 19 członków, a po 9 latach działalności liczba ta zwiększyła się ponad 30-krotnie. Instytucja chętnie organizowała wykłady o tematyce zielarskiej. Informacje branżowe PKZ zaczął publikować w „Wiadomościach Farmaceutycznych”, by umożliwić jak największej liczbie osób łatwy dostęp do wiedzy. Duże zainteresowanie naukowców oraz rolników gazetą spowodowało, że od 1934 r. artykuły wydawano w osobnym czasopiśmie o nazwie „Wiadomości Zielarskie” [Głowacki 1991].

Polski Komitet Zielarski (PKZ) utrzymywał się ze składek członkowskich oraz subwencji władz państwa. Szczególną troskę o wsparcie finansowe Komitetu Zielarskiego wykazywało Ministerstwo Spraw Wojskowych, które w zamian oczekiwało wyhodowania maku wysokomorfinowego do produkcji leków przeciwbólowych. Priorytetem PKZ było nawoływanie do zwiększania areału uprawy ziół w Polsce i prowadzenie prac doświadczalnych, które ułatwić miały uprawę polową. $\mathrm{Na}$ zlecenie ministra rolnictwa komitet opracował listę gatunków roślin zielarskich z uwzględnieniem wymagań glebowych, nakładów 
finansowych oraz zapotrzebowania rynku. Uprawa ziół w Polsce skupiła się głównie w regionie ówczesnego województwa warszawskiego, łódzkiego, kieleckiego i poznańskiego. Rozwój zielarstwa w dwudziestoleciu międzywojennym wiązał się z zainteresowaniem przemysłu farmaceutycznego surowcami pochodzenia roślinnego. Współdziałanie członków PKZ $\mathrm{z}$ naukowcami umożliwiało standaryzację procesów analitycznych i chemicznych ziół. Komitet Zielarski na cele nauki corocznie przekazywał nieodpłatne próbki materiałów badawczych oraz fundusze niezbędne do pracy laboratoriów. Ważnym aspektem przemian sektora zielarstwa było nawiązanie współpracy międzynarodowej oraz utworzenie Federacji Zielarskiej. Otwarcie rynków zagranicznych spowodowało wzrost podaży ziół produkowanych w naszym kraju [Magowska 1999].

Zielarze, świadomi zbliżającej się wojny, uczyli dzieci rozpoznawania ziół i stosowania ich w celach leczniczych. Nieletni tworzyli dziecięcą armię zielarską, która miała pomóc rannym w wyniku działań wojennych. Druga wojna światowa przyniosła załamanie na rynku ziół i upadek PKZ, rozwiązanego przez okupanta. Niemieckie władze zobowiązały rolników do produkcji zbóż i roślin okopowych, koniecznych do produkcji żywności, skutecznie zmniejszając areał uprawy roślin leczniczych. Utrudniono także pracę polskich przetwórców surowców zielarskich, pozbawiając ich zysków. Stopniowo firmy takie trafiały w ręce niemieckich handlowców, którzy wykorzystując swoją przewagę sprzedawały zioła z marżą nawet ponad $800 \%$. Okupant większy potencjał upatrywał w zbieractwie owoców leśnych. Polacy, zachęcani otrzymaniem kilograma mąki w zamian za kilogram malin lub dwa kilogramy jagód, zaprzestali zbierania ziół i zajęli się zbieractwem runa leśnego [Magowska 2009].

Wojna zniszczyła dużo - dorobek naukowy i uprawy ziół, lecz z pewnością nie zapał rolników do odnowienia plantacji. W miejsce PKZ utworzono Polski Związek Zielarski (PZZ), a następnie w 1947 r. z inicjatywy doktora Strażewicza Państwowy Instytut Naukowy Leczniczych Surowców Roślinnych (PINLSR) z siedzibą w Poznaniu. System gospodarki sterowanej powodował jednak liczne utrudnienia w odbudowie sektora zielarskiego. Socjalizm zakładał własność wspólną, dlatego większość gospodarstw zielarskich zostało przekształconych w państwowe organizacje. Ziemi nie odebrano jedynie rolnikom uprawiającym rośliny na powierzchni do 0,5 ha. W latach 40 . XX w. powstało Zjednoczenie Przemysłu Zielarskiego „Herbapol”, które w bezpośredni sposób pozwoliło na rozwój zielarstwa w kolejnych latach i zwiększenie powierzchni upraw do ponad 20 tys. ha. Coraz bardziej popularne, szczególnie na terenie obecnego województwa wielkopolskiego, stawały się umowy kontraktacyjne, zapewniające stabilne warunki współpracy, co zachęcało rolników do uprawy ziół. Kontraktacje dotyczyły najczęściej uprawy kolendry oraz mięty pieprzowej. Umowy o takim charakterze cechowała dobrowolność, jednak ich liczba była ściśle powiązana z ustaleniami Ministerstwa Rolnictwa [Lipińska 2013]. 
Na skutek zmian sytuacji politycznej w roku 1989 czternaście zakładów należących do Zjednoczenia Przemysłu Zielarskiego Herbapol zostało zlikwidowanych lub trafiło $\mathrm{w}$ ręce prywatnych przedsiębiorców. Likwidacja części przedsiębiorstw wymusiła zawieszenie działalności zielarzy w wybranych regionach Polski, gdzie zaprzestano przetwórstwa surowców zielarskich. Prywatyzacja pozostałych zakładów doprowadziła do zmniejszenia powierzchni zasiewów ziół ze względu na niewielkie ceny zbytu ustalane przez nowych właścicieli [Mikołajczyk-Grzelak 2008].

Wiek XXI przyniósł zmniejszenie ogólnej powierzchni uprawy ziół do poziomu 14,5 tys. ha. W roku 2001 średnia powierzchnia gospodarstwa zielarskiego wynosiła 1,88 ha, a po upływie dekady wzrosła o niespełna 0,2 hektara. Gospodarstwa zielarskie skupiły się głównie na obszarze Mazowsza, Lubelszczyzny, Wielkopolski oraz Kujaw i Pomorza. Do najważniejszych instytucji wspierających współczesne zielarstwo należy Instytut Włókien Naturalnych i Roślin Zielarskich (IWNiRZ) oraz Polski Komitet Zielarski (PKZ), którego działalność rektywowoano w roku 1993 [Olewnicki i in. 2015].

\section{Pionierzy polskiego zielarstwa}

W wieku XX zielarstwo straciło swój pierwotny, ludowy charakter. Stało się jedną z gałęzi gospodarki i ważną dyscypliną farmacji. Poszerzanie wiedzy dotyczącej ziół możliwe było dzięki osobom działającym na rzecz tej dziedziny rolnictwa, promującym zielarstwo w kraju i na świecie.

Jednym z najważniejszych pionierów zielarstwa jako dziedziny farmacji był Jan Biegański, żyjący w latach 1870-1938. Po ukończeniu na kijowskim uniwersytecie studiów farmaceutycznych, zdobywał cenne doświadczenie nie tylko jako farmaceuta we własnej aptece, mieszczącej się na ziemiach płockich, ale również jako ogrodnik uprawiający rośliny lecznicze. Efektem jego pracy było wydanie książki „Rośliny lekarskie i ich uprawa”, która była doskonałym kompendium wiedzy na temat agrotechniki, wymagań klimatycznych oraz właściwości ponad 300 gatunków ziół. Po zakończeniu I wojny światowej Biegański propagował zielarstwo poprzez wygłaszanie referatów, a także wydawanie kolejnych publikacji. Był jednym z założycieli Towarzystwa Popierania Produkcji Roślin Leczniczych działającego w latach 1926-1930. Rozpowszechnianie fitoterapii wśród obywateli Polski było życiowym celem Biegańskiego [Magowska 2009].

Kolejnym propagatorem zielarstwa był Wacław Jan Strażewicz (1889-1950), który po odzyskaniu przez Polskę niepodległości rozpoczął kształcenie na Uniwersytecie Wieleńskim. W roku 1933 uzyskał tytuł naukowy doktora habilitowanego farmacji. Był jednym z najbardziej cenionych nauczycieli akademickich i wybitnym naukowcem. Dzięki redagowaniu podręczników zielarskich trwale wpisał się w rozwój zielarstwa w kraju [Głowacki 1991]. 
Na rzecz wzmocnienia roli zielarstwa wśród ludów rolniczych działał także Jan Marian Dobrowolski (1886-1958). Był on inicjatorem akcji nawołujących do zbieractwa ziół, uważając je za szansę dla rozwoju ziołolecznictwa i świetlanej przyszłości tej gałęzi rolnictwa. Wiedzę o właściwościach roślin zdobywał jako członek armii austriackiej, w której zobowiązany był do prowadzenia plantacji ziół leczniczych. Dobrowolski nigdy nie wstąpił do Polskiego Komitetu Zielarskiego, ale ściśle z nim współpracował [Magowska 2009].

Propagowaniem zielarstwa zajmował się Jan Kazimierz Muszyński (1884-1957), który do kraju po wojnie wrócił z siedmioma skrzyniami zbiorów botanicznych, licznymi publikacjami zielarskimi oraz preparatami mikroskopowymi. W niepodległej Polsce pełnił funkcję urzędnika w Ministerstwie Zdrowia oraz kierownika Katedry Farmakognozji Uniwersytetu Wieleńskiego, gdzie wraz z doktorem Strażewiczem założył ogród roślin leczniczych stosowanych w nowoczesnej fitoterapii. Muszyński swoją wiedzą i doświadczeniem dzielił się z członkami Polskiego Komitetu Zielarskiego, którego był inicjatorem [Magowska 2009].

Żyjący w latach 1886-1970 polski biolog i profesor Uniwersytetu Jagiellońskiego Władysław Szafer zasłużył się dla zielarstwa poprzez tworzenie map występowania ziół leczniczych, ułatwiając lokalne zbieractwo [Magowska 2009].

Współcześnie żyjącym pionierem zielarstwa w naszym kraju jest doktor Jerzy Jambor (ur. 1951) prezes Polskiego Komitetu Zielarskiego oraz wybitny naukowiec w dziedzinie zielarstwa i fitoterapii. Jambor jest współtwórcą wielu leków pochodzenia roślinnego, między innymi preparatów Dentosept, Sylimarol, Bioaron C [www.kierunekfarmacja.pl].

\section{Aktualna sytuacja zielarstwa w Polsce}

Rozwój zielarstwa w ostatnich dekadach wiąże się z rosnącym znaczeniem fitoterapii, czyli współczesnej metody leczenia za pomocą substancji roślinnych. Ich dobroczynne działanie poparte jest licznymi badaniami naukowymi [Grzesik-Gąsior i in. 2018]. Nad wprowadzaniem do obrotu środków leczniczych pochodzenia roślinnego kontrolę sprawuje Światowa Organizacja Zdrowia oraz Europejska Agencja ds. Leków [Baraniak i Kania 2015]. Aktualnie uprawa ziół uchodzi za dochodowy kierunek produkcji rolnej. Szansą dla tysięcy polskich rolników jest eksport ziół, którego wartość w 2013 r. utrzymywała się na poziomie blisko 460 tys. t, przy sześciokrotnie niższej wielkości importu [Rokicki i Wiluk 2016]. Wsparcie finansowe gospodarstw zielarskich możliwe jest także dzięki funduszom unijnym. W ramach operacji „Modernizacja gospodarstw rolnych” dla poddziałania „Pomoc na inwestycje w gospodarstwach rolnych" PROW 2014-2020 dla województwa podlaskiego wprowadzono dodatkowo punktowane kryterium przyznawania pomocy, jeżeli operacja przyczynia się bezpośrednio do rozszerzenia profilu produkcji gospodarstwa o zielarstwo [www.arimr.gov.pl]. Z terenów tych pochodzi większość 
surowców zbieranych ze stanu naturalnego. Wybór tego kryterium dla Podlasia jest także ściśle związany $\mathrm{z}$ dynamiką zmian $\mathrm{w}$ strukturze zasiewów na tych obszarach w ostatnich latach. Obserwuje się tam jedno z najwyższych w kraju tempo zwiększania areału ziół. Choć podlascy zielarze nie znajdują się w czołówce producentów tych roślin w warunkach polowych, zamieszkiwane przez nich tereny uznawane są za potencjalnie przyszłościowe dla zielarstwa ze względu na duże zasoby surowców ze zbieractwa i korzystne warunki do wzrostu ziół [Olewnicki $\mathrm{i}$ in. 2015].

Historia zielarstwa wpłynęła znacząco na obecne losy branży. Szczególnie ważne było utworzenie Polskiego Komitetu Zielarskiego, który pomimo przerw w działalności do dzisiaj pełni rolę pośrednika pomiędzy rolnikami a przetwórcami. Po trudach wojny i przemian politycznych został reaktywowany w celu wspierania działań naukowych. Pierwsze lata działalności w wolnej Polsce skupiały się przede wszystkim na odbudowaniu rynku ziół, który po upadku Herbapolu został rozchwiany. Komitet umożliwił tworzenie na terenie kraju sklepów zielarskich, które pozwoliły na dotarcie do wielu tysięcy konsumentów. Przełom wieków XX i XXI przyniósł rozwój fitofarmakologii, czyli działu nowoczesnej medycyny i farmacji wykorzystującej leki roślinne wytworzone w oparciu o wszechstronną wiedzę naukową i ludowe tradycje. Wejście Polski do Unii Europejskiej umożliwiło Polskiemu Komitetowi Zielarskiemu nawiązanie współpracy z rolnikami uprawiającymi zioła poprzez wdrażanie w ich gospodarstwach zasad Kodeksu Dobrej Praktyki Rolniczej. Przestrzeganie zaleceń kodeksu jest gwarantem otrzymania surowców spełniających restrykcyjne normy jakościowe. W dobie rynku rolnego opartego na spekulacjach i prognozach zapotrzebowania na surowce do najważniejszych zadań Komitetu należy promocja polskich produktów zielarskich i współpraca międzynarodowa, dająca szansę eksportu ziół do krajów Unii Europejskiej oraz całego świata. Stowarzyszenie reprezentuje interesy zielarzy na arenie politycznej i integruje wszystkich plantatorów, umożliwiając rozwój zielarstwa poprzez kształcenie, dyskusję oraz propagowanie surowców pochodzenia roślinnego [www.pkz.pl].

Pomimo burzliwej historii marka „Herbapol” niezmiennie kojarzy się milionom Polaków z ziołami. Państwowe przedsiębiorstwa zielarskie powstałe w XX w., choć w roku 1989 trafiły w ręce prywatnych przedsiębiorców, nadal realizują cele i wartości pierwotnych zakładów - tworzenie produktów pochodzących z zasobów naturalnych opartych na mądrości medycyny ludowej poprzednich pokoleń oraz licznych badaniach współczesnych naukowców. Na terenie kraju pod marką „Herbapol” działają obecnie: Herbapol Wrocław, Herbapol Lublin, Herbapol Poznań, Herbapol Kraków oraz Herbapol Warszawa [Jambor 2007].

W Europie rolnicy uprawiają ponad 100 gatunków ziół, w Polsce około 50. Wynika to przede wszystkim z uwarunkowań klimatycznych. Firmy zajmujące się przetwórstwem ziół w Polsce wskazują 15 gatunków roślin szczególnie ważnych dla krajowej produkcji leków i preparatów roślinnych oraz przypraw. 
Są to: szałwia lekarska, mięta pieprzowa, melisa lekarska, bazylia pospolita, majeranek ogrodowy, koper włoski, kozłek lekarski, dziurawiec zwyczajny, cząber ogrodowy, ostropest plamisty, nagietek lekarski, arcydzięgiel lekarski, jeżówka purpurowa, babka lancetowata oraz malwa czarna. Części użytkowe tych roślin przeznaczane są na cele farmaceutyczne oraz przyprawowe. Ponadto wiele $\mathrm{z}$ nich jest gatunkami miododajnymi i ozdobnymi, a także znajdującymi zastosowanie $\mathrm{w}$ przemyśle gorzelniczym. Dla przemysłu ważną rolę pełnią surowce takie jak nasiona, korzenie, ziele czy kwiaty. Szerokie wykorzystanie części użytkowych zebranych roślin zielarskich umożliwia wyspecjalizowanie gospodarstw zielarskich i przygotowanie odpowiedniego zaplecza technicznego do uprawy i sprzedaży [Newerli-Guz 2015].

\section{Podsumowanie}

Historia oraz obyczajowość związana $\mathrm{z}$ ziołami znacząco wpłynęła na współczesne zielarstwo wyróżniające się postępem naukowym i technicznym. Kluczowymi wydarzeniami w przeszłości, które wpłynęły na losy zielarstwa w Polsce, było powstawanie instytucji i stowarzyszeń dbających o interesy zielarzy i wysoką jakość produkowanych przez nich surowców. Ich działalność powodowała zainteresowanie tym sektorem i zakładanie rodzinnych gospodarstw zielarskich, których tradycja kultywowana jest po dzień dzisiejszy przez kolejne pokolenia. Działalność Polskiego Komitetu Zielarskiego, który pomimo wojen i zmian politycznych odrodził się w wolnej Polsce i propaguje zielarstwo $\mathrm{w}$ największym stopniu wpłynęła na obecny kształt rynku zielarskiego. Gospodarstwa zielarskie, choć niewielkie, są miejscem produkcji wysokojakościowych surowców zielarskich, a ich wyspecjalizowanie możliwe jest dzięki szerokim możliwościom wyboru gatunków do uprawy oraz finansowemu wsparciu z Unii Europejskiej. Rolą Komitetu jest także promowanie wyprodukowanych w Polsce ziół oraz poszukiwanie zagranicznych rynków zbytu. Integrowanie plantatorów pozwala na wymianę doświadczeń oraz rozwój badań naukowych dotyczących ziół.

Negatywny w skutkach był proces likwidacji i prywatyzacji państwowych Herbapoli, które jako państwowe organizacje $\mathrm{z}$ pewnością dysponowałyby większymi możliwościami, szczególnie w aspekcie gwarancji cen skupu i eksportu. Zielarze zmuszeni są do podejmowania współpracy $\mathrm{z}$ prywatnymi przedsiębiorcami, stosującymi często nieetyczne praktyki tak zwanej „zmowy cenowej". Realnie obniża to dochody osób utrzymujących się z uprawy ziół. Ponadto problemem jest zbyt słaba kontrola surowców importowanych do naszego kraju, szczególnie pod względem zawartości pozostałości środków ochrony roślin, których stosowanie dozwolone jest $\mathrm{w}$ innych krajach. Polscy rolnicy mają bardzo ograniczone możliwości stosowania chemikaliów, co korzystnie wpływa na jakość surowców zielarskich, jednak gwałtownie zwiększa nakłady pracy ludzkiej. 
Państwowe zakłady zapoczątkowały także zawieranie umów kontraktacyjnych, bardzo powszechnych aktualnie we współpracy rolników i firm przetwórczych.

Praca naukowców w ostatnim stuleciu zaowocowała wydawaniem licznych publikacji, książek oraz czasopism zielarskich. Przyczynia się to do zwiększania wiedzy rolników, zajmujących się uprawą ziół oraz coraz większej świadomości konsumentów na temat działania substancji czynnych pochodzenia roślinnego.

Wszystkie przemiany, które zaszły w ostatnim stuleciu, wpłynęły na obecną sytuację zielarstwa opartą na wolnorynkowym zbycie surowców. Zmiany w tym sektorze zachodzą bardzo dynamicznie, dlatego ważne jest wsparcie ze strony Ministerstwa Rolnictwa. Powinno ono zapewnić równy dostęp do dotacji ubezpieczeń upraw od ryzyka zagrożeniami atmosferycznymi oraz dotacji europejskich dla zielarzy, których uprawy są wyłączone $\mathrm{z}$ systemu pomocy. Zielarstwo jest rozwojowym kierunkiem produkcji, dzięki rosnącemu znaczeniu fitoterapii oraz dużemu zainteresowaniu konsumentów preparatami roślinnymi.

\section{Bibliografia}

Baraniak J., Kania M., 2015. Suplementy diety, środki spożywcze specjalnego przeznaczenia żywieniowego a lek roślinny w świetle współczesnej fitoterapii. Post. Fitoter. 3, 177-183.

Głowacki W., 1991. Wacław Jan Strażewicz, znawca zielarstwa i farmakognosta (1889-1950). Kwart. Hist. Nauki Tech. 36(1), 145-158.

Grzesik-Gąsior J., Bień A., Pieczykolan A., 2018. Fitoterapia w infekcjach ginekologicznych jako naturalne wsparcie w procesie leczenia. Pielęgn. XXI Wieku 17, 3(64), 69-73.

Jambor J., 2007. Zielarstwo w Polsce - stan obecny i perspektywy rozwoju. Post. Fitoter., 2, 78-81.

Lipińska I., 2013. Współczesna rola umowy kontraktacji. J. Agribus. Rural Dev. 1(27), 1-10.

Magowska A., 1999. Z historii zielarstwa w okresie międzywojennym: relacje z ochroną przyrody. Kwart. Hist. Nauki Tech. 44(2), 95-106.

Magowska A., 2009. Zioła - świetlana przyszłość Polski... Historia Polskiego Komitetu Zielarskiego (1929-2009). Wyd. Kontekst, Poznań, ss. 414.

Mikołajczyk-Grzelak N., 2008. Produkcja roślin zielarskich w Polsce. Rocz. Nauk. Stow. Ekon. Rol. Agrobiz. 10(4), 270-273.

Newerli-Guz J., 2015. Uprawa roślin zielarskich w Polsce. Rocz. Nauk. Stow. Ekon. Rol. Agrobiz. $18(3), 268-274$.

Olewnicki D., Jabłońska L., Orliński P., Gontar Ł., 2015. Zmiany w krajowej produkcji zielarskiej i wybranych rodzajach przetwórstwa roślin zielarskich w kontekście globalnego wzrostu popytu na te produkty. Probl. Rol. Świat. 15(30), 1, 68-76.

Rokicki T., Wiluk M., 2016. Handel zagraniczny ziołami i przyprawami w krajach Unii Europejskiej. Probl. Rol. Świat. 16(31), 2, 269-278.

www.arimr.gov.pl/dla-beneficjenta/wszystkie-wnioski/prow-2014-2020/poddzialanie-413modernizacja-gospodarstw-rolnych/modernizacja-gospodarstw-rolnych-nabor-19-lutego-20marca-2018-r.html [dostęp: 18.02.2020].

www.kierunekfarmacja.pl/artykul,6886,dr-n-farm-jerzy-jambor.html [dostęp: 15.02.2020].

www.pkz.pl/about-us/ [dostęp: 19.02.2020]. 